ERNESTO TZIRULNIK

\title{
SEGURO DE RISCOS DE ENGENHARIA: INSTRUMENTO DO DESENVOLVIMENTO
}

Tese de Doutorado

Orientador: Professor Titular Gilberto Bercovici

Faculdade de Direito da Universidade de São Paulo

São Paulo

2014 
Banca Examinadora 
Is this the end of the beginning?

Or the beginning of the end?

Losing control or are you winning?

Is your life real or just pretend?

Reanimation of the sequence Rewinds the future to the past. To find the source of the solution;

The system has to be repaired.

$(\ldots)$

End of the beginning - Black Sabbath 


\section{AGRADECIMENTOS}

Henrique e Apparecida, meus saudosos pais, sempre deram exemplo de liberdade, trabalho e engajamento. Deles nunca me faltaram o estímulo e os recursos necessários para estudar. O último presente que me deram foi uma caneta para que pudesse assinar esta tese. A eles meu profundo agradecimento.

Os Professores e amigos Alberto Monti, Alejandro Vigil, Antônio Carlos Marcato, Athos Gusmão Carneiro, Cláudio Ferraz de Alvarenga, Donaldo Armelin, Fábio Ulhoa Coelho, Felipe Aguirre, Flávio de Queiroz Bezerra Cavalcanti, Francisco Artigas, Fernando Antônio Sodré Faria, Hamilton Mesquita do Prado, Humberto Theodoro Júnior, Humberto Roncarati, Jacques Bergman, Jean Bastin, João Calvão da Silva, José Joaquim Calmon de Passos, José Carlos Moitinho de Almeida, José Eduardo Martins Cardozo, José María Muñoz Paredes, José Sollero Filho, Judith Martins-Costa, Luc Mayaux, Ovídio Araújo Baptista da Silva, Pablo Medina Magallanes, Paulo Roberto de Zoppa, Paulo Miguel Marracini, Pedro Purm, Sérgio Sérvulo da Cunha, Rubén Stiglitz, Ronaldo Porto Macedo, Ruy Rosado de Aguiar, Vera Helena de Mello Franco e Wady José Mourão Cury, sempre me ajudaram a confiar e servir ao Seguro e ao Direito. Fernando Lopes Nunes apresentou-me a ética na atividade seguradora e os seguros da engenharia.

O entusiasmo do Alessandro Octaviani foi decisivo para que me inscrevesse no programa de pós-graduação onde, de braços abertos, corajoso e generoso, acolheu-me o meu orientador, Professor Gilberto Bercovici, sem cujo exemplo, estímulo e compreensão, jamais chegaria este momento.

Agradeço também o carinho e a atinada crítica dos Professores e amigos Erasmo Valadão de Azevedo e Novaes França e José Tadeu De Chiara.

Agradeço às companheiras Jéssica Bastos, Bianca Tavolari e Lea Vidigal Medeiros, cuja sensibilidade, disciplina, crítica e paciência foram coautoras do esforço. Devo gratidão, ainda, ao excepcional auxílio das solidárias tradutoras Mônica Gonçalves e Rosie Mehoudar e ao apoio cuidadoso da Gabriela Gomes da Silva.

Também foram importantes as pesquisas feitas pelos estagiários Frederico Haddad, Gabriel Chagas e Michel Edelstein, e a ajuda dos amigos e colegas Maurício Luís Pinheiro da Silveira, Paulo Luís de Toledo Piza, Wolf Ejzenberg, Carlos Leal de Carvalho, 
Tiago Moraes, Dina Marques Bernardes, Walfrido Jorge Warde Jr., João Alves da Silva e André Jacques Luciano Uchoa Costa.

Finalmente, sou grato pelo apoio e pelo amor que sempre recebi de todos que me acompanharam até hoje, da minha esposa Lili, das minhas filhas Ilana e Tayla, do meu filho André e das minhas netas Eva e Leona. 


\section{RESUMO}

O objetivo deste trabalho é examinar o seguro de riscos de engenharia como instrumento para o desenvolvimento. A perspectiva adotada é a da articulação entre direito e economia política: parte-se da ideia de que as categorias jurídicas instauram determinada economia política. Nesse sentido, os contratos de seguro serão entendidos de forma indissociada das operações comunitárias em que se encerram e de sua especial tarefa de reorganização social e econômica. A função social dos contratos de seguro é revelada como conteúdo obrigatório da própria autonomia da vontade atinente a esses contratos.

A relação entre seguro e desenvolvimento é ainda mais evidente nos seguros de risco de engenharia, objeto específico deste trabalho. Institucionalizada desde a década de 1930, a função desenvolvimentista desses seguros tem seu declínio a partir dos anos 1970 com nítida agravação no ano de 2007, quando ocorre a abertura do mercado brasileiro de resseguro. Defende-se a tese de que a legislação brasileira sobre seguro de risco de engenharia é inadequada, atuando de forma impeditiva do desenvolvimento nacional. A principal razão para isso está na perda paulatina de conteúdo desses seguros, em parte promovida pelo próprio Estado, capturado pelos interesses dos empresários do setor. A tentativa de anulação da teoria do interesse consagrada não só na longeva praxe dos seguros, como pela doutrina nacional e estrangeira e plasmada no art. 757 do Código Civil, é um dos principais argumentos explorados.

Por fim, são apresentados dispositivos do Projeto de Lei do Senado n. 477/2013, que procura trazer para o sistema de direito positivo a primeira lei de contrato de seguro da história brasileira, com o objetivo de reordenar as relações contratuais, eliminando as principais práticas desfuncionalizadoras e em busca dos escopos fixados na Constituição de 1988.

Palavras-chave: direito econômico, seguro, riscos de engenharia, contrato, construção, instalação e montagem, desenvolvimento, função social, socialidade, projeto de lei contrato de seguro, IRB, SUSEP, resseguro. 


\begin{abstract}
The aim of this study is to examine engineering risk insurance as an instrument of development. The perspective adopted here is an articulation between Law and Political Economy, beginning with the idea that legal categories determine political economy. In this sense, insurance contracts are construed as non-dissociated from the community operations to which they belong and from their special task of social and economic reorganization. The social function of insurance contracts is seen as an inexorable part of the autonomous will involved in such contracts.

The relationship between insurance and development is even more evident in engineering risk insurance, which is the specific object of this study. Having been institutionalized since the 1930s, the developmental function of this type insurance began to decline in the mid-1980s, and clearly worsened in 2007, when the Brazilian reinsurance market was opened. We propose that the Brazilian legislation on engineering risk insurance is inadequate and acts as an impediment to national development. The main reason for this is the gradual loss of content in this type of insurance, in part promoted by the State itself, captive to the interests of industry executives. The attempt to nullify the theory of interest - well established not only in longstanding insurance practice, but also in national and international tenets, and shaped by Article 757 of the Brazilian Civil Code - is one of the main arguments explored here.

Finally, we present some provisions of Senate Bill no. 477/2013 that seeks to incorporate into the system of positive law Brazil's first law of insurance contract, the aim of which is to reorder contractual relations by eliminating the major defunctionalizing practices, in keeping with the intentions of the 1988 Constitution.
\end{abstract}

Keywords: Economic Law, Insurance, Engineering risks, Contract, Construction, Installation and assembly, Development, Social function, Sociality, Bill, Insurance contract, IRB, SUSEP, Reinsurance. 


\section{RiassunTO}

Il presente lavoro è dedicato all'analisi dell'assicurazione dei rischi di ingegneria come strumento per lo sviluppo. La prospettiva adottata è l'articolazione tra diritto ed economia politica: si parte dall'idea che le categorie giuridiche instaurano una determinata economia politica. In questo senso, i contratti di assicurazione vengono intesi in forma indissociata dalle operazioni comunitarie in cui sono compresi e dal loro speciale compito di riorganizzazione sociale ed economica. La funzione sociale dei contratti di assicurazione è descritta come contenuto obbligatorio della propria autonomia della volontà inerente a tali contratti .

Il rapporto tra assicurazione e sviluppo è ancora più evidente nelle assicurazioni dei rischi di ingegneria, oggetto specifico di questo lavoro. La funzione di sviluppo di queste assicurazioni, istituzionalizzata durante gli anni '30, trova il suo declino a partire dalla metà degli anni '80 con un netto aggravamento nel 2007, quando viene aperto il mercato brasiliano della riassicurazione. Si difende la tesi che la legislazione brasiliana sull'assicurazione dei rischi di ingegneria è inadeguata, costituendo un impedimento per lo sviluppo nazionale. La ragione principale di questo è la graduale perdita di contenuto delle assicurazioni, in parte promossa proprio dallo Stato, condizionato dagli interessi degli imprenditori del settore. Il tentativo di annullare la teoria dell'interesse, consacrata non solo dalla longeva prassi delle assicurazioni, ma anche dalla dottrina nazionale e straniera, e plasmata nell'art. 757 del Codice Civile, è uno dei principali argomenti esplorati.

Sono presentati, infine, i dispositivi del Disegno di Legge del Senato n. 477/2013, che cerca di inserire nel sistema del diritto positivo la prima legge sul contratto di assicurazione della storia brasiliana, al fine di riordinare le relazioni contrattuali, eliminando le principali pratiche disfunzionalizzanti, alla ricerca degli obiettivi indicati nella Costituzione del 1988.

Parole chiave: Diritto Economico, Assicurazione, Rischi di Ingegneria, Contratto, Costruzione, Installazione e Montaggio, Sviluppo, Funzione Sociale, Socialità, Disegno di Legge, Contratto di Assicurazione, IRB, SUSEP, Riassicurazione. 


\section{SUMÁRIO}

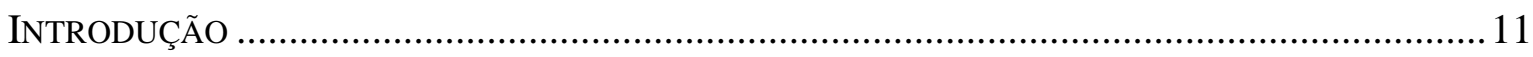

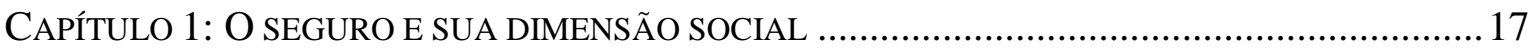

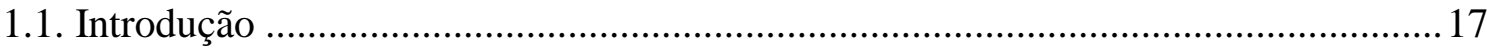

1.2. Breves considerações sobre as origens históricas do seguro ................................... 18

1.3. Formação de uma comunidade de compartilhamento de riscos................................2 21

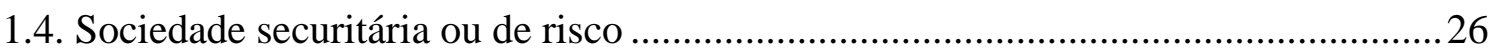

1.5. Direito do seguro como resposta à insuficiência da responsabilidade civil ............... 33

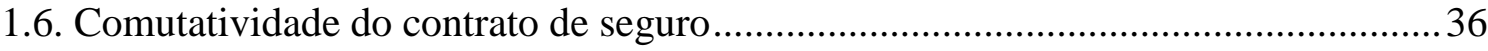

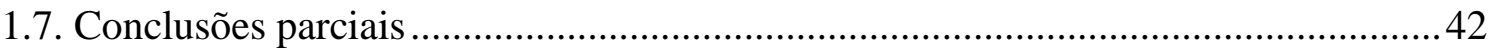

CAPÍTULO 2: A FUNÇÃO SOCIAL DO CONTRATO DE SEGURO ................................................... 44

2.1 O princípio da função social do contrato e o princípio da relatividade do contrato .. 44

2.2 Perspectivas jurídicas sobre a função social do contrato ............................................53

2.3 Perspectivas econômicas sobre a função social do contrato ....................................... 64

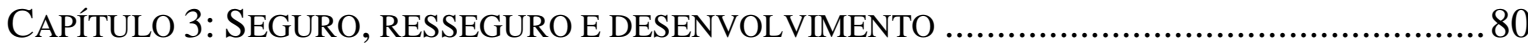

3.1. Regulação e dimensão institucional do seguro no Brasil ........................................... 80

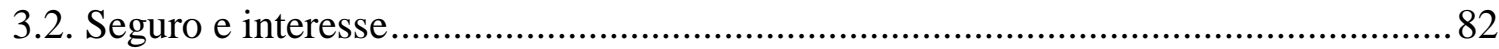

3.3. Função desenvolvimentista do seguro e do resseguro ........................................... 88

3.4. A intervenção estatal na doutrina sobre seguro: balanço crítico ............................. 103

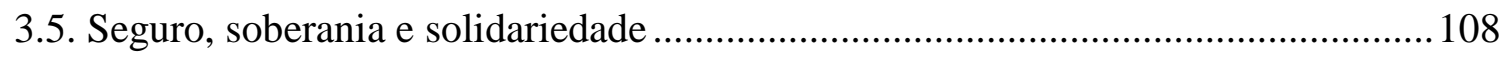

3.6. Intervenção estatal e constituição econômica ......................................................... 111

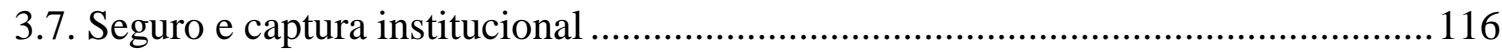

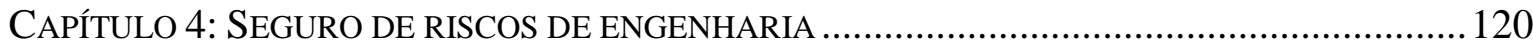

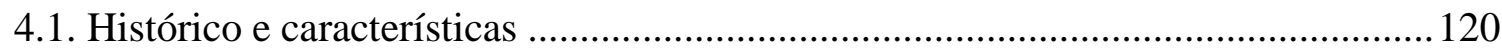

4.2. Crise do seguro de riscos de engenharia no Brasil................................................ 129

4.2.1. Negação do interesse e redução do conteúdo de garantia dos seguros de riscos

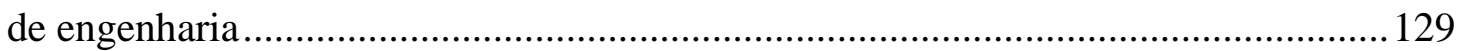

4.2.2. Regulamentação dos seguros de risco de engenharia no Brasil ........................ 134

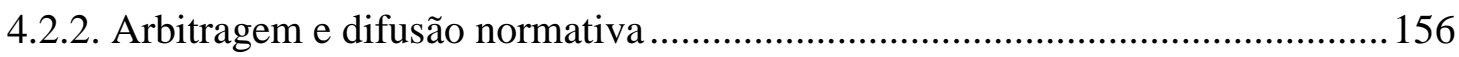

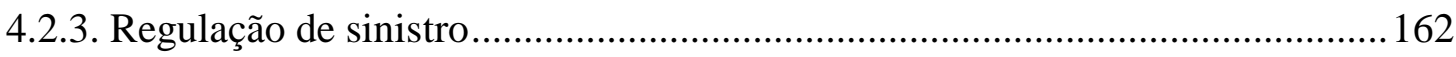


CaPítulo 5: Projetos de Lei de Contrato de Seguro ................................................. 167

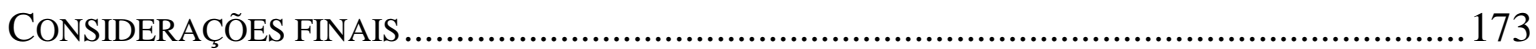

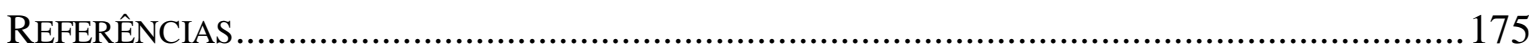




\section{INTRODUÇÃO}

Não há disputa quanto ao fato de que vivemos um momento da história posterior à ascensão dos Estados de bem-estar social. Agora, o liberalismo individualista, adornado pela ideologia da proteção ao consumidor, potencializado pela progressiva redução do Estado e pela substituição das funções públicas por organismos de mais fácil captura ("agências") ou pela ação direta das empresas privadas, impõe-se como arauto do desenfreado capitalismo financeiro.

A sociedade, especialmente nos países que lutam pela superação do subdesenvolvimento, perde progressivamente os instrumentos de proteção estatais, consequência natural não apenas do movimento ideológico, como do intenso processo de minimalização do Estado que ele implica.

Aqueles que produzem doutrina jurídica devem reconhecer que esse momento histórico impõe o engajamento na luta pelas emancipações de todos os indivíduos e dos países, como lembra Luiz Gonzaga BELLUZZO, citando uma mensagem de Felix Frankfurter, dirigida ao presidente Roosevelt, a propósito da oposição que então se fazia à política social intervencionista que veio a salvar a economia norte-americana da severidade dos efeitos da crise de 1929:

Quando os homens mais proeminentes do mundo da finança escancaram atitudes moralmente obtusas e antissociais, chega-se à conclusão de que o verdadeiro inimigo do capital não é o comunismo, mas os capitalistas e sua corte de escribas e advogados. ${ }^{1}$

Aqui se trama o testemunho da experiência securitária com perseverança dos que acreditam que, sob o modo de produção capitalista, é possível intervir nas atividades econômicas através do Estado para promover a melhora da vida das pessoas e avançar o desenvolvimento social e econômico, especialmente em países com tantos atrasos e desequilíbrios como o Brasil.

Este trabalho parte do pressuposto de que o seguro e sua arquitetura jurídica são instrumentos para o desenvolvimento nacional. Essa relação se torna ainda mais explícita no caso dos seguros de risco de engenharia. Obras complexas de infra-estrutura com grande mobilização de capital público e privado não são realizadas sem instrumentos de

\footnotetext{
${ }^{1}$ BELLUZZO, Luiz Gonzaga. 1929 e 2008: Reações à crise. Carta Capital, ano XIX, n. 767, 25 de setembro de 2013, p. 47.
} 
garantia adequados. Estradas, usinas, malha ferroviária, aeroportos e estações de metrô, apenas para citar alguns exemplos, são projetos fundamentais para todos os países, especialmente para aqueles em desenvolvimento.

É também por essa razão que o seguro será analisado a partir da articulação entre direito e economia política. Por meio de suas categorias dogmáticas, o direito implementa uma economia política. A perspectiva adotada aqui, portanto, é a da forma jurídica da economia política, corrente do direito econômico que vem sendo desenvolvida principalmente na Universidade de São Paulo. Nas palavras de Alessandro OCTAVIANI: "[e]ntender e prescrever a economia política que vai colada à decisão jurídica é tarefa do jurista e do reformador social". O pressuposto é o de que ainda "há espaço para a obra política no espaço das nações e do mundo, com vistas a realizar a democracia."2

A tese defendida neste trabalho é a de que a legislação brasileira é inadequada em matéria de seguros, especialmente no que diz respeito ao seguro de risco de engenharia. Por "inadequada" entendo que a atual legislação brasileira é impeditiva do desenvolvimento nacional, que serve antes de bloqueio do que de facilitadora do desenvolvimento. Há algumas razões para isso. O argumento central é o de que essa inadequação tem origem na perda de centralidade da função social do seguro, comumente entendido a partir de cada uma das relações individuais que não teriam qualquer vínculo mais amplo com o restante da sociedade. No âmbito propriamente jurídico, identifica-se a passagem de uma teoria do interesse para a materialização de danos físicos no contrato de seguro de risco de engenharia, movimento que solapa a função social do seguro com graves perdas ao desenvolvimento.

A experiência com a advocacia para seguradoras por mais de três décadas permitiu a formação do seguinte diagnóstico: alguns empresários do seguro, em busca da maior penetração dos seus serviços, procuram oferecer "produtos securitários" úteis para a sociedade - ou seja, com conteúdos de garantia adequados às necessidades dos contratantes e que promovem a solidarização da sociedade. Essa atribuição de funcionalidade aos serviços oferecidos, contudo, embora tenha o mérito de provar que a funcionalização dos seguros é possível, é entretanto prontamente abandonada quando surge o risco de contenção das margens de lucro. Prevalecem, sobre o objetivo de prestar serviços amoldados à dignidade humana e condizentes com a função social das relações

\footnotetext{
${ }^{2}$ OCTAVIANI, Alessandro. Recursos genéticos e desenvolvimento - Os desafios furtadiano e gramsciano. São Paulo: Saraiva, 2013, p.25.
} 
obrigacionais, bem como do desenvolvimento indispensável para tanto, os interesses dos acionistas na crescente rentabilidade das companhias de seguros e resseguros.

Quando se erguem como valores o bem-estar dos segurados, dos beneficiários e da sociedade, os negócios e suas políticas naturalmente tendem a ser retirados do estado de conforto proporcionado pelo individualismo liberal. A percepção da ameaça ou o mero risco de que venha a ser ameaçada a zona de conforto faz com que os seguradores e resseguradores saiam em defesa do status quo.

Isso é tanto mais grave quando o seguro tende a cumprir certas funções próprias dos Estados, erigindo-se como verdadeiro instrumento de governo, como ensinam ERICSON, DOYLE e BARRY num dos mais interessantes e profundos estudos sobre o neoliberalismo e a assunção das funções estatais e dos controles de políticas públicas pelas instituições financeiras, notadamente seguradoras e resseguradoras:

O seguro é uma instituição essencial para o governo das sociedades modernas. Ele tem se tornado cada vez mais significativo porque as sociedades contemporâneas encorajam um estado mínimo e um governo baseado no conhecimento local do risco. ${ }^{3}$

Nas últimas décadas, diante de pequenos, porém múltiplos, sinais de que a racionalidade jurídica brasileira se colocava a favor dos segurados e beneficiários - aliás, sentido que deveria orientar também a conduta dos governantes, uma vez que o sistema prevê intervenção estatal em favor dos segurados e beneficiários ${ }^{4}-$, seguradoras e resseguradoras sentiram ameaças à margem de lucro de suas atividades. Assim, a "racionalidade empresarial" reagiu para fazer com que os agentes produtores da chamada ordem jurídica - legisladores e intérpretes -, conscientemente ou não, recuperassem o vigor do sistema principiológico típico da mais tradicional ordem jurídica liberal e se mobilizassem para desconstrução de importantes conquistas sociais já obtidas. Como analisarei nesta tese, uma dessas conquistas diz respeito justamente ao conteúdo dos seguros de riscos de engenharia. As grandes conquistas da dogmática contratual, por exemplo, sofreram continuada ação neutralizadora por parte dos juristas a serviço do setor securitário, entre outros.

\footnotetext{
${ }^{3}$ ERICSON, Richard Victor, DOYLE, Aaron, BARRY, Dean. Insurance as governance. Toronto: University of Toronto Press Incorporated, 2003, p. 359: "Insurance is a core institution in governing modern societies. It has become increasingly significant because contemporary societies encourage a minimal state and government based on local knowledge of risk." Daqui em diante, todas as traduções serão minhas quando não houver indicação expressa.

${ }^{4}$ Decreto-Lei n. 73, de 21 de novembro de 1966, art. 2: "O controle do Estado se exercerá pelos órgãos instituídos neste Decreto-lei, no interesse dos segurados e beneficiários dos contratos de seguro.”
} 
Assim, a ideia de função social do contrato que já poucos procuram amarrar à busca de redução das desigualdades e à solidarização social, passou a sofrer o ataque ferrenho de doutrinadores e juízes, a fim de corresponder à máxima fruição lícita do contrato. Nesse sentido, é oportuna a advertência de Vera Helena de Melo FRANCO para quem, salienta-se desde logo, a função social é limite da liberdade contratual e não elemento do conteúdo do vínculo contratual, diferença que será discutida posteriormente:

O Código Civil Brasileiro de 2002, nesta linha evolutiva, acatou na sua norma do art. 421 o princípio da função social do contrato, elegendo-o como razão e limite da liberdade de contratar, para admitir a autonomia privada somente enquanto esta respeite os limites traçados por esta função. Acata-se com isto o princípio da solidariedade social tal como preconizado pela constituição de 1988 , art. $3^{\circ}$, III, in fine.

Mas o que se deve entender por função social? A acepção varia ao sabor das diversas ideologias, a partir do momento em que se confunde com a ética social, vigente num determinado momento, em um igualmente determinado agrupamento. A assim ser, o seu conteúdo fica a cargo da visão, mais ou menos conservativa, progressista ou revolucionária, particular do intérprete. ${ }^{5}$

A dimensão ideológica das disputas em torno do seguro também é enfatizada por ERICSON, DOYLE e BARRY, para os quais "o seguro é a instituição de governança para além do Estado" e "compartilha muitos dos objetivos do Estado". O Estado, por sua vez, "colabora com a indústria de seguro no âmbito da ideologia". 6

Essa interação ideológica entre Estado e indústria do seguro é facilmente identificada nos atos normativos produzidos nas últimas três décadas pela então sociedade de economia mista monopolista do resseguro no país, originalmente denominada Instituto de Resseguros do Brasil, e pela Superintendência de Seguros Privados, autarquia federal fiscalizadora das operações securitárias. Mais adiante serão apresentados atos normativos que consubstanciam esse processo de captura, atinentes, entre outros, aos seguros de riscos de engenharia.

A irmanação ideológica entre o Estado e as empresas seguradoras também produz o que o Ministro Ricardo Villas Boas CUEVA, do Superior Tribunal de Justiça, denominou "movimento pendular": a mudança de posição da Corte, que antes se inclinava

\footnotetext{
${ }^{5}$ FRANCO, Vera Helena de Mello. Teoria Geral do Contrato: confronto com o direito europeu futuro. São Paulo: RT, 2011, p. 65.

${ }^{6}$ Op. cit., p. 360-361: "insurance is the institution of governance beyond the state (...) shares many of the goals of the state (...) [The state] collaborates with the insurance industry at the level of ideology".
} 
para a afirmação dos direitos dos segurados e, nos últimos anos, passou a pender para posição oposta, ao prestigiar os interesses das seguradoras. ${ }^{7}$

No final da década passada, além do engajamento na luta pelo advento da primeira lei brasileira de contrato de seguro, uma lei que se busca ${ }^{8}$ seja comprometida com o desenvolvimento econômico e social, com a atuação do Estado a favor do povo em geral e não contra as instituições financeiras "fundamentais para a república"9, a experiência com que se trama este estudo passou a ser formada, também de maneira intensa, a partir do patrocínio de grandes segurados ("grandes riscos" ou "riscos vultosos") e de pequenas empresas e pessoas físicas ("riscos de massa").

A poliédrica experiência permitiu identificar que a hegemonia das instituições financeiras, entre as quais se encontram as seguradoras e resseguradoras, produziu efeitos negativos não apenas nos chamados seguros de massa, como também nos de grande vulto, entre os quais se encontram os seguros de riscos de engenharia, que sofrem contínua e acentuada perda de conteúdo, isto é, perda de eficácia da garantia dos interesses ameaçados pelos acidentes, fenômeno iniciado após o declínio do monopólio brasileiro do resseguro e, contraditoriamente, no momento em que a política estatal dá prioridade a obras de infraestrutura que demandam esses seguros. No campo dos seguros de riscos de engenharia ou de construção, portanto, o próprio Estado sofre os efeitos da despublicização.

Essa tomada de consciência proporcionada pelo exercício profissional no setor de seguros encaixa-se perfeitamente com as circunstâncias históricas.

Quando até mesmo os instrumentos de apoio ao processo de desenvolvimento de nossas sociedades acham-se desprovidos de eficácia, como acontece com os seguros de construção, é urgente enfrentar o fantasma da novidade e integrar a socialidade ínsita aos seguros com a função social dos contratos, utilizando os instrumentos da constituição econômica.

\footnotetext{
${ }^{7}$ IV Congresso Internacional de Direito Securitário (CIDISE 2013), palestra “A visão do contrato de seguro na análise da jurisprudência do STJ", São Paulo, 10 de junho de 2013.

${ }^{8}$ Desde 2000, por meio do IBDS - Instituto Brasileiro de Direito do Seguro, contribuo com a formulação e acompanhamento da primeira tentativa brasileira de criação de Lei de Contrato de Seguro (Projetos de lei n. 3.555/2004, do Sr. José Eduardo CARDOZO, e n. 8.034/2010, do Sr. Rubens MOREIRA MENDES). Diante da urgência com que o país reclama sua lei de contrato de seguro e do conteúdo retrógrado do Substitutivo apresentado na pertinente Comissão Especial pelo Relator Deputado Armando Vergílio dos SANTOS JÚNIOR, presidente da Federação Nacional dos Corretores de Seguro (FENACOR), membro do conselho dirigente da Fundação Escola Nacional de Seguros (FUNENSG) e ex superintendente da SUSEP, foi apresentado no Senado, o Projeto de Lei n. 477/2013, do senador Humberto COSTA, que incorpora quase todo o conteúdo dos mencionados projetos que tramitam na Câmara dos Deputados.

9 "A estabilidade do sistema financeiro é transformada em bem público", salienta Eros GRAU, no prefácio do livro A crise atual do Capitalismo, de António José Avelãs NUNES. São Paulo: RT, 2012, p. 8.
} 
Mostraremos, assim, que os seguros vêm sofrendo perdas substanciais de utilidade ao opacar-se o Estado e ascender o capitalismo financeiro que entroniza a ideologia liberal individualista, atingindo esse processo de declínio a qualidade ou eficácia garantidora dos seguros de riscos de engenharia ou de construção. Procuraremos mostrar, também, que a função social necessita ser reconhecida como elemento do contrato para que a ordem jurídica, especialmente o chamado direito privado, possa atuar para recuperar a eficácia perdida. Finalmente, apresentaremos os esforços que, nesse mesmo sentido, empreendem os Projetos de Lei n. 3.555/2004 e n. 8.034/2010, assim como o Projeto de Lei do Senado n. 477/2013, primeiras tentativas de outorgar ao país sua Lei de Contrato de Seguro. 


\section{CAPÍtUlo 1: O SEGURO E SUA DiMENSÃo SOCIAL}

Para se tornar operacional a teoria do risco, sem disfuncionalidade, impôs-se a solução pelo seguro, que institucionaliza, em termos técnicos, o imperativo da solidariedade numa sociedade de riscos.

José Joaquim Calmon de PASsos. "O Risco na sociedade moderna e seus reflexos na teoria da responsabilidade civil e na natureza jurídica do contrato de seguro" in: I Fórum de Direito do Seguro "Jose Sollero Filho", 2001, São Paulo. Max Limonad, 2001, p. 13.

\subsection{Introdução}

Os seguros permeiam os mais diversos âmbitos da vida social. Estão presentes em atos simples e cotidianos como alugar um apartamento, comprar um carro ou fazer uma viagem. São também essenciais em operações de maior complexidade e que envolvem grandes riscos, como a construção de uma usina hidrelétrica, uma linha de metrô ou uma fábrica. Comumente são também premissas indispensáveis para a obtenção de crédito e para o exercício das atividades empresariais (financiamentos, investimentos, ingresso e permanência nas bolsas, participação em concorrências etc.). Assim, integram as mais diversas relações e são um dos elementos de sua forma jurídica.

À primeira vista, o seguro surge de uma motivação puramente individual, de um interesse que diz respeito unicamente àquele que busca proteção relativa a algum bem ou pessoa que lhe sejam caros. Quem aluga um apartamento deseja ter uma garantia caso o imóvel não lhe seja restituído em bom estado ou o inquilino não pague aluguel e encargos em dia, assim como construtoras e empreiteiras buscam dar maior segurança a seus negócios, numa tentativa de blindá-los contra os prejuízos causados por acidentes que dificilmente poderiam ser previstos. Nesse sentido, a relação jurídica de seguro se daria entre duas partes específicas e identificáveis, como forma de proteger um interesse individual de um risco provável projetado para o futuro. 
Apesar de ainda ter adeptos importantes ${ }^{10}$, a concepção do seguro como uma relação inter partes guiada apenas pelo interesse individual é insuficiente tanto para descrever como essas relações se dão de fato quanto para pensar o instituto do seguro como instrumento para o desenvolvimento econômico. O objetivo desse capítulo é apresentar argumentos que, em vários planos, apontam para elementos das relações de seguro que transcendem o âmbito puramente individual e que mostram uma dimensão propriamente social dos seguros.

O primeiro passo é reconstruir as origens históricas do seguro de forma a explicitar como a dimensão social já está presente desde o momento inicial de sua formação (1.2). Em seguida, o seguro é analisado a partir da perspectiva da constituição de uma comunidade de compartilhamento de riscos (1.3). A socialidade do seguro ganha expressão ainda maior em teorias contemporâneas que concebem nossa sociedade como uma sociedade de risco, o que generaliza o risco e a necessidade de seguro para uma coletividade ainda maior (1.4). A dimensão social pode ainda ser percebida se entendermos o direito de seguro como resposta às insuficiências das categorias dogmática de responsabilidade civil (1.5) e também na discussão a respeito da natureza comutativa dos contratos de seguro (1.6).

\subsection{Breves considerações sobre as origens históricas do seguro}

Apesar de uma noção de compartilhamento de riscos e de um instrumento análogo ao seguro poderem ser remontados aos negócios marítimos da Mesopotâmia ${ }^{11}$, a origem do

\footnotetext{
${ }^{10}$ É interessante notar que uma parte da literatura dogmática alemã sobre seguro confere centralidade a seus aspectos essencialmente privados. Michael TERBILLE define o contrato de seguro como "as relações jurídicas que abarcam a obrigação de seguro de direito privado em face a uma pessoa determinada" (TERBILLE, Michael (ed.). Versicherungsrecht: Münchener Anwalts Handbuch. München: C. H. Beck, 2004, p. 13). Posição semelhante é adotada por Erich PRÖLSS ao dar continuidade aos comentários de Anton Martin sobre a lei de contrato de seguro. Ver PRÖLSS, Jürgen; MARTIN, Anton (eds.). Versicherungsvertragsgesetz. 27 ${ }^{\mathrm{a}}$ edição. München: C. H. Beck, 2004. Em sentido contrário, ver EHRENBERG, Victor Gabriel Merkel. Das "Interesse“ im Versicherungsrecht. München: Dunker und Humblot, 1915.

11 "This tendency of the investing merchant happens totally with the desire of the traveling merchant to spread the risk of the venture. The division of the risk represents in fact a very primitive form of maritime insurance which precedes that in which the risk is transferred - for a fee - to other persons under various forms, i. e. real marine insurance. Examples for the distribution of the risk in maritime ventures are not too frequent in the texts from Ur." OPPENHEIM, L. A. "The Seafaring Merchants of Ur". Journal of the American Oriental Society. vol 74, n. 1, (Jan-Mar), 1954, p. 9. Tradução livre: "Essa tendência do mercador investidor coaduna-se totalmente com o desejo do mercador viajante de diluir o risco do empreendimento. A divisão do risco representa de fato uma forma muito primitiva de seguro marítimo que precede aquela na qual
} 
seguro e da própria noção de risco se confunde com a formação inicial do capitalismo no final da Idade Média. ${ }^{12}$ Michel ALBERT identifica dois momentos históricos: uma origem mais antiga, que daria início ao que o autor chama de tradição "alpina",13, e uma origem marítima mais conhecida, vinculada ao florescimento das cidades italianas do Mediterrâneo:

\begin{abstract}
A origem mais antiga dos seguros localiza-se nos altos vales dos Alpes, onde os aldeões organizaram as primeiras sociedades de socorro mútuo na virada do século XVI. Desta tradição "alpina" descende toda uma filiação de organismos comunitários de seguros e de previdência: guildas, corporações, sindicatos profissionais, movimentos mutualistas. Esta tradição "alpina" mutualiza os riscos: cada indivíduo suporta um custo relativamente independente da probabilidade de ocorrência dos riscos que lhe é própria. De tal maneira que existe uma 'solidariedade' e finalmente uma transferência 'redistributiva' no interior da comunidade. Esta tradição conservou sua marca na área geográfica em que nasceu: a Suíça, a Alemanha... e, para além, nos países de sensibilidade comparável sobre este ponto, como por exemplo, o Japão. A outra origem dos seguros é a marítima. É o empréstimo altamente aventureiro para as cargas dos navios venezianos ou genoveses, que se desenvolverá em seguida sobretudo em Londres. Sua forma característica ser-lhe-á dada na taverna de um tal de Lloyd, em Londres, relativamente às cargas de chá embarcadas nos navios ingleses. Esta filiação é diferente da tradição "alpina": trata-se menos de segurança e mais de uma gestão especulativa e de desempenho do risco. ${ }^{14}$
\end{abstract}

Essas duas tradições distintas mostram uma verdadeira disputa em torno do conceito de seguro. Enquanto a tradição alpina está mais vinculada a uma preocupação de redistribuição e de solidariedade, a tradição marítima estaria centrada no objetivo de lucro e procuraria avaliar a probabilidade de risco de cada um dos comerciantes da forma mais exata possível, ou seja, teria a calculabilidade como principal preocupação. Essa disputa de concepções refletiria, para ALBERT, uma diferença de modelos de capitalismo:

É por esta razão que as duas origens do seguro projetam-se hoje com uma nova claridade sobre os dois modelos do capitalismo contemporâneo. De um lado, o capitalismo anglo-saxão, fundado sobre o predomínio do acionista, o lucro financeiro a curto prazo e, de forma mais geral, sobre o êxito financeiro individual; de outro lado o capitalismo renano, no qual a preocupação com o longo prazo e a preeminência da empresa, percebida

o risco é transferido - por uma taxa — para outras pessoas sob várias formas, ou seja, o seguro marítimo real. Exemplos de distribuição do risco em empreendimentos marítimos não são muito frequentes nos textos de Ur."

12 Para uma discussão mais detalhada sobre as primeiras expressões e sobre a origem etimológica do termo risco, ver LUHMANN, Niklas. Soziologie des Risikos. Berlin/New York: de Gruyter, 1991, p. 17 e ss.

13 A expressão "alpina" ou "alpino-renana" deve-se ao fato de que as estrutras securitárias comuniárias surgem nas regiões dos Alpes e vale do rio Reno. É aí que despontam e se desenvolvem os mais importantes resseguradores, como "Zurich", "Swiss", "Munich".

${ }^{14}$ ALBERT, Michel. Capitalismo versus Capitalismo. São Paulo: Loyola, 1992, p. 106 e ss. 
como uma comunidade na qual se associam capital e trabalho, são objetivos prioritários. ${ }^{15}$

Ainda que a solidariedade seja a tônica apenas do seguro de origem mais antiga, nenhuma das duas tradições pode ser descrita apenas a partir de um enfoque individual. $\mathrm{O}$ seguro de origem alpino-renana, fundado nas organizações, guildas e sindicatos, exige a constituição de uma associação de fato que atende a um interesse coletivo, necessita de um vínculo social entre os participantes para constituir um fundo de socorro mútuo. Já o seguro maritimista, ainda que, segundo ALBERT, não organize a solidariedade e esteja embasado num cálculo instrumental entre meios e fins, também é uma empreitada coletiva de gestão dos riscos. Isso porque as navegações comerciais italianas constituíram associações que não podem ser adequadamente descritas como mera agregação de partes individuais: a organização, a criação de fundos e a divisão do trabalho são elementos que corroboram a ideia da formação mais imediata de uma comunidade de pessoas e interesses.

Já os seguros de riscos relacionados à engenharia ou construção têm uma origem ainda mais explicitamente atrelada ao capitalismo, uma vez que remontam à Revolução Industrial, às caldeiras a vapor do século XIX. Fabricantes e usuários de caldeiras que se reuniam para o enfrentamento da infortunística desses equipamentos, instrumento essencial para a indústria da época, terminam por criar a Associação de Usuários de Vapor de Manchester. Essa associação, que prestava serviços de inspeção de riscos e assistência técnica aos usuários das caldeiras, levou à criação da primeira seguradora especializada:

Se pensó que la inspección con seguro sería un paso importante hacia adelante y bastante atractivo para los industriales y usuarios de vapor. Como no todos los miembros de esa asociación estaban conformes con el seguro, varios de ellos fundaron en 1858 la primera compañía de seguros de ingeniaría, la Steam Boiler Assurance Company, a la que siguieran otras compañías similares. ${ }^{16}$

Essas breves considerações sobre as origens históricas do seguro permitem ver que o pressuposto dessas associações era o compartilhamento de interesses em grupos com elementos identitários - ou, se quisermos, de classe - comuns. O reconhecimento de uma comunidade que compartilha riscos é o elemento coletivo mais imediato do seguro e trataremos dele em mais detalhes na seção seguinte.

\footnotetext{
${ }^{15}$ Idem.

${ }^{16}$ CHARTERED INSURANCE INSTITUTE. Seguro de ingeniaría. $2^{\mathrm{a}}$ edição, tradução espanhola por Manuel Vivas Díaz-Berrio, Madri: Ed. Mapfre, 1979, p. 3, 5 e 6.
} 


\subsection{Formação de uma comunidade de compartilhamento de riscos}

La operación 'seguro' no es factible de ser entendida desde un punto de vista técnico-económico, fuera de una mutualidad de asegurados y con la intervención de una empresa como intermediaria entre una pluralidad de sujetos expuestos a riesgos determinados. Lo expuesto implica aceptar, de inicio, que el seguro no es posible comprenderlo, en su función económica ni técnica, como la asunción aislada de las consecuencias dañosas de un riesgo al que se halla sometido un sujeto.

Rubén S. STigLiTZ. Derecho de seguros. Tomo 1, 4ª ed., Buenos Aires. La Ley, 2004, p. 2.

Os elementos indicados por STIGLITZ permitem uma primeira caracterização da comunidade de compartilhamento de riscos nas relações de seguro. Ele enfatiza a pluralidade de sujeitos que compõem essa relação e, para além do número, a mutualidade entre os segurados, a necessidade de que compartilhem riscos e proteções:

Lo expresado presupone una transformación del riesgo individual en riesgo colectivo. De más en más, ha quedado rezagada la idea que el seguro importa una transferencia del riesgo, porque, en suma, la función básica que cumple está dada, en lo que socialmente interesa y se enuncia, como un instrumento al servicio de la eliminación de las consecuencias que se derivan de la realización de un riesgo, a través de la constitución de una mutualidad que lo afronta, neutralizando las consecuencias económicas individual y colectivamente dañosas. ${ }^{17}$

Os assegurados criam vínculos entre si e o risco individual se dispersa em uma pluralidade de riscos que, segundo STIGLITZ, conforma a noção de comunhão ou mutualidade. Assim, podemos caracterizar a atividade ou empresa seguradora como aquela que se desenvolve por meio de uma grande comunidade de contratos e que é universalmente reconhecida como instrumento essencial para a preservação das forças produtivas ameaçadas pelo acidente.

Nessa primeira definição, a atividade consiste na reunião, por uma entidade especializada (seguradora), de um expressivo número de pessoas (grupo assegurado) com interesses (relações com bens da vida) expostos a ameaças do mesmo tipo (riscos). Com base nas contribuições pagas por essas pessoas (prêmios) será formado um fundo

\footnotetext{
${ }^{17}$ STIGLITZ, Rubén S. Derecho de seguros. Tomo 1, 4ª ed., Buenos Aires. La Ley, 2004, p. 2.
} 
econômico-financeiro (reservas e provisões), sob gestão da seguradora ${ }^{18}$, capaz de atribuir a cada um a garantia (cobertura) de que, uma vez realizados os riscos (sinistros, como danos ou outros fatos) e atingidos negativamente seus interesses (ensejando necessidades ou prejuízos), haverá uma prestação, em geral pecuniária, destinada à compensação dos interesses afetados (reposição, indenização ou capital).

Em poucas palavras, a empresa seguradora ou securitária pode ser entendida como aquela que, por meio de uma coletividade expressiva de contratos, reúne e administra as contribuições destinadas a garantir as unidades econômicas expostas ao surgimento de necessidades (assistência em sinistros, apoio para contenção de perdas, capitais, indenizações), ao homogeneizar os riscos na comunidade e coletivizar os custos dos acidentes.

A afirmação de que a operação securitária é um fenômeno coletivo e indissociável não é rara entre os que se detiveram no seu exame. Grande parte da doutrina rejeita a possibilidade de se apreender qualquer perfil da atividade securitária se o exame se detiver numa ou em poucas das operações que nela estão contidas. Qualquer percepção válida somente pode ser obtida mediante o exame de uma operação de seguro a partir dos elementos que contribuem para um sistema geral que transcende os interesses das partes contratantes.

Comentando a respeito das redes ou sistemas contratuais, "com o que se construiu a ideia de uma eficácia pluri-contratual e supra-contratual", Judith MARTINS-COSTA ressalta que o mérito da doutrina civilista da segunda metade do século $\mathrm{XX}$, foi

(...) evidenciar que nenhuma relação obrigacional é um fim em si mesmo, antes se apresentando como mecanismo e como processo teleologicamente estruturado em vista de sua finalidade que é a satisfação da totalidade dos interesses envolvidos na relação, estando, portanto, no cerne do conceito as noções de "atividade", "dinamismo" e de "totalidade". 19

MARTINS-COSTA prossegue advertindo que

18 A estruturação financeira das seguradoras, muito além dos capitais integralizados pelos acionistas, assenta-se num fundo que provém da receita de prêmios, acolhida em patrimônio independente ou no passivo, razão pela qual a doutrina fala em gestão de poupança pública: "[l]as enormes sumas de dinero de que disponen las empresas de seguro provienen del ahorro público, que merece la máxima protección" ETCHEBARNE, Conrado. "El Control por el Estado de las Empresas de Seguro". Revista del Derecho Comercial y de las Obligaciones. ano 3, 1970, p. 675.

${ }^{19}$ MARTINS-COSTA, Judith,. Parecer inédito intitulado Contrato de resseguro. IRB - Brasil Resseguros S.A.. Contratos necessários. Conexidade contratual. Função social do contrato e exercício jurídico disfuncional. Deveres de proteção. Ilicitude. Sociedade de economia mista. Princípio da impessoalidade e prática discriminatória, emitido em 15 de agosto de 2008, p. 23. 
para além da relação entre os sujeitos contratantes o contrato pode ter também uma dimensão que interesse a toda sociedade, ou a um grupo de pessoas - para além dos contratantes -, de modo que o interesse do grupo prevaleça sobre o interesse de cada um dos seus membros. ${ }^{20}$

Nesse mesmo sentido, Miguel REALE já ensinava que a autonomia da vontade implica também a promoção de interesses de terceiros estranhos aos vínculos jurídicos individualmente observados, devendo ser compatibilizados os interesses dos contratantes com o da sociedade em geral:

Não há razão alguma para se sustentar que o contrato deva atender tão somente aos interesses das partes que o estipulam, porque ele, por sua própria finalidade, exerce uma função social inerente ao poder negocial, que é uma das fontes do direito (...) assim sendo, é natural que ele seja concluído em benefício dos contratantes sem conflito com o interesse público. ${ }^{21}$

Gilberto BERCOVICI propõe que o princípio da função social é auto-operativo, não dependendo de expressa previsão. Esse princípio não apenas fundamenta, justifica e legitima os negócios privados, vinculando-os a um interesse maior da coletividade, como deve ser também tomado em conta para a interpretação dos negócios. A relevância da publica utilitas dos atos de vinculação entre os privados, do princípio da função social, para o autor, "legitima a desaplicação das disposições legislativas nascidas como expressões de tipo individualista ou atuativas de uma função social diversa daquela constitucional., 22

Essa, aliás, era a questão central quando se resolveu nacionalizar a atividade seguradora no Brasil nos anos 1930, como lembra Agamenon MAGALHÃES, o então Ministro do Trabalho, ao rebater um memorial crítico anônimo distribuído pelos opositores da nacionalização, em trecho que citamos: “Com o desenvolvimento das actividades e do commercio, não era mais possível que o seguro pudesse corresponder à sua funccão social e econômica, sem resseguro.",23

A doutrina é abundante a respeito desse fenômeno obrigacional que o seguro estereotipa. Giuseppe BAVETTA lembra que as leis pertinentes às operações de seguro, de “indubitável relevância social”, têm uma "particularidade interessante”. Elas objetivam

\footnotetext{
20 Idem, p. 30.

${ }^{21}$ REALE, Miguel. "Função social do Contrato". In: REALE, Miguel. História do Novo Código Civil, São Paulo: Revista dos Tribunais, 2005, p. 267.

${ }^{22}$ BERCOVICI, Gilberto. Constituição econômica e desenvolvimento: uma leitura a partir da Constituição de 1988. São Paulo: Malheiros, 2005, p. 147-148.

23 "Respostas às críticas feitas em um memorial anonymo, distribuído pelos interessados contra a nacionalização" in O Anteprojeto de nacionalização das sociedades de seguros e o Instituto Federal de Resseguros, p. 45.
} 
tutelar os segurados mediante a reintegração, na massa de operações, de cada relação obrigacional, que "em certos limites, não tem autonomia" e está "especificamente destinada" à mencionada reintegração:

Desse modo, no atual arranjo moderno do fenômeno securitário, a operação individual não é considerada apenas pelo que representa na economia das relações individuais, mas é igualmente significativa e é levada em consideração porque contribui para a realização de um sistema geral que (embora não os esquecendo) transcende os interesses particulares das partes.

Com referência ao seguro em geral, portanto, a perspectiva amplia-se: não é tanto (ou, de qualquer modo, não somente) um segurado específico que se visa tutelar, mas os segurados como um todo, isto é, todos aqueles que de uma forma ou de outra tenham recorrido ao seguro e, por isso mesmo, se inseriram no sistema pertinente. A verdade é, portanto, que a lei visa obter um resultado muito mais amplo, que é justamente aquele de oferecer um sistema idôneo para atender às exigências da massa de segurados, os quais se encontram em avançado estado de desenvolvimento; ou seja, visa alcançar uma finalidade realmente particular, que é a de garantir objetivamente, no plano econômico e jurídico, a validade de recorrer ao seguro, de modo que (não apenas um, mas) todos os segurados encontrem, no momento oportuno, pronta resposta a seu ato de previdência.

Que dessa forma também se consiga tutelar o segurado individual faz parte dos fins práticos programados pelo legislador e consagrados no complexo sistema de seguro: porque, é óbvio, no plano prático, a tutela da massa de segurados se traduz, substancial e principalmente, na própria tutela do indivíduo (segurado); tutela, que não é prejudicada, mas que, ao contrário, se fortalece. No entanto, não se pode perder de vista que foi dado ao fenômeno securitário um arranjo muito especial: que concerne não a este ou aquele segurado, mas à massa de segurados. Desse ponto de vista, portanto, o seguro tem uma inquestionável relevância social. [...]

$\mathrm{Na}$ atual organização de seguros, portanto, há algo de particular e interessante: que a operação de seguro individual, dentro de certos limites, não permanece autônoma. Na verdade, é especificamente destinada a ser confundida na massa dos outros atos análogos, e a eles se integra. $^{24}$

24 BAVETTA, Giuseppe. L'impreza di assicurazione. Milão: Giuffrè, 1972, p. 1-3. Original em italiano: "In tal modo, nell'attuale moderno assetto del fenomeno assicurativo, la singola operazione non viene in considerazione soltanto per ciò che essa rappresenta nell'economia dei rapporti individuali, ma è altresì significativa e viene presa in considerazione in quanto concorre alla realizzazione di un sistema generale che (pur non obliandoli, tuttavia) transcende gli interessi particolari delle parti. Con riferimento all'assicurazione in generale, pertanto, la prospettiva si allarga: non è tanto (e, comunque, non soltanto) il singolo assicurato che si mira a tutelare, ma gli assicurati nel loro complesso, cioè tutti coloro che in un modo o in un altro hanno fatto ricorso all'assicurazione e si sono perciò stesso inseriti nel relativo sistema. Il vero è dunque che la legge mira a conseguire un risultato di ben più vasto respiro, che è appunto quello di apprestare un sistema idoneo a sopperire alle esigenze della massa degli assicurati, quali si presentano in un'economia in avanzato grado di sviluppo; mira, cioè, a raggiungere una finalità affatto particolare, che è quella di garantire obiettivamente, sul piano economico e giuridico, la validità del ricorso all'assicurazione, in maniera che (non uno soltanto, ma) tutti gli assicurati trovino, al momento opportuno, pronta risposta al loro atto di previdenza. Che in tal modo si finisca anche con il tutelare il singolo assicurato, rientra nei fini pratici programmati dal legislatore e consacrati nel complesso sistema delle assicurazione: chè, com'è ovvio, sul piano pratico, la tutela della massa degli assicurati si traduce sostanzialmente e principalmente appunto nella tutela del singolo (assicurato); tutela, che non viene ad essere pregiudicata, ma che, anzi, ne esce rafforzata. Non può tuttavia 
A operação de seguro não é, portanto, uma somatória de contratos que podem nascer, ter genótipos distintos e ser infalivelmente executados com independência uns dos outros.

Yvonne LAMBERT-FAIVRE define a atividade seguradora, em expressão bastante significativa, como "uma operação anti-aleatória de luta coletiva contra o infortúnio" ${ }^{25}$. Essa anti-aleatoriedade ressalta a importância econômica e social do seguro e influi sobre a disciplina jurídica da empresa ${ }^{26}$, também avança sobre os contratos que necessariamente se conjugam, como visto, para a concretude da empresa seguradora, exalando, como observa Judith MARTINS-COSTA, “a noção de comunidade, uma vez

perdersi di vista che al fenomeno assicurativo é stato dato un assetto del tutto speciale: esso riguarda non questo o quest'altro assicurato, ma la massa di essi. Da tale punto di vista, dunque, l'assicurazione ha un'indubbia rilevanza social. [...] Nell'attuale assetto delle assicurazioni, dunque, v'è questo di particolare ed interessante: che la singola operazione assicurativa, entro certi limiti, non resta autonoma: è, anzi, specificamente destinata ad essere confusa nella massa degli altri atti analoghi, e si integra con questi."

25 LAMBERT-FAIVRE, Yvonne. Droit des Assurances, 11 a ed., Paris, Dalloz, 2001, p. 39 : "Alors que le contrat d'assurance prend l'aspect d'un pari ou d'un jeu du hasard, l'operation d'assurance, envisagée globalement, devient une opération anti-aléatoire de lute collective contre le hasard". Tradução livre : "Enquanto o contrato de seguro toma o aspecto de uma aposta ou de um jogo de azar, do acaso, a operação de seguro, encarada globalmente, torna-se uma operação antialeatória de luta coletiva contra o acaso [o risco, o infortúnio]".

Para John F. DOBBYN: "While there is no way to transfer the risks of pain, inconvenience, or sorrow that accompany any misfortune, the device of insurance serves to distribute the risk of economic loss among as many as possible of those who are subject to the same kind of risk. By paying a pre-determined amount (premium) into a general fund out of which payment will be made for an economic loss of the defined type, each member contributes to a small degree toward compensation for losses suffered by any member of the group. The member has no way of knowing in advance whether he will receive in compensation more than he contributes or whether he will merely be paying for the losses of others in the group; but his primary goal is to exchange the gamble of going it alone, whereby he could either escape all loss whatsoever or suffer a loss that might be devastating, for the opportunity to pay a fixed and certain amount into the fund, knowing that that amount is the maximum he will lose on account of the particular type of risk insured against. This broad sharing of economic risk is the principle of risk distribution". DOBBYN, John F. Insurance law in a nutshell. $2^{\mathrm{a}}$ ed. St. Paul: West, 1999, p. 3-4. Tradução livre: "Enquanto não existe modo de transferir os riscos de dor, inconveniência, ou sofrimento que acompanham qualquer infortúnio, o dispositivo do seguro serve para distribuir o risco de perda econômica entre tantos quanto possíveis dos que estão sujeitos à mesma espécie de risco. Por pagar uma quantia predeterminada (prêmio) a um fundo geral do qual os pagamentos serão feitos para uma perda econômica do tipo definido, cada membro contribui em pequeno grau para a compensação das perdas sofridas por qualquer membro do grupo. Nenhum membro tem como saber previamente se ele receberá em compensação mais do que contribuiu ou se simplesmente pagará pelas perdas de outros do grupo; mas seu principal objetivo é trocar o risco de agir sozinho, pelo qual poderá tanto escapar de toda e qualquer perda como sofrer uma perda que pode ser devastadora, pela oportunidade de pagar uma quantia fixa e certa para o fundo, sabendo que essa quantia é o máximo que perderá em decorrência do risco particular contra o qual ele se segura. Essa ampla partilha do risco econômico é o princípio da distribuição do risco."

26 Giuseppe BAVETTA: "[s]ua rilevanza giuridica. - L'importanza economica e sociale che l'assicurazione è venuta via assumenti non ha mancato di influire sull'impresa assicuratrice e sulla sua disciplina giuridica. $\mathrm{E}$ non essere diversamente: chè, più è venuto avvertendo che l'assicurazione svolge una funzione sociale e maggiore è stata l'esigenza di introdurre negli schemi privastici, propri dell'impresa assicuratrice, quelle istanze pubblicistiche che sono ormai immanenti nel fenomeno assicurativo." BAVETTA, Giuseppe. L'impreza di assicurazione. Milão: Giuffrè, 1972, p. 4. 
que num dos polos não está meramente o interesse de uma soma aritmética de 'individualidades', mas interesses supra individuais ou coletivos" ${ }^{\text {"27. }}$.

\subsection{Sociedade securitária ou de risco}

Se as origens históricas do seguro e a formação de uma comunidade que compartilha riscos apontam para diferentes aspectos da dimensão coletiva dos seguros, teorias sociais contemporâneas ampliam consideravelmente a escala em que essa coletividade é pensada. Autores como Ulrich BECK, Niklas LUHMANN e François EWALD dão centralidade ao risco - e às tentativas de proteção contra ele - na construção de um diagnóstico sobre a sociedade contemporânea. Assim, risco e seguro deixam de ser categorias restritas a relações jurídicas entre grupos determinados e, na visão desses autores, passam a caracterizar a própria forma com que se estrutura a sociedade atual.

Publicado pela primeira vez em 1986, A sociedade do risco de Ulrich BECK se tornou um livro de referência e de grande influência para além dos limites das ciências sociais. Por meio dessa nova categoria - sociedade do risco -, o autor desenvolve uma interpretação para as transformações da sociedade industrial. Trata-se, assim, de dar uma resposta teórica para modificações estruturais de nossa época sem recorrer ao prefixo pós tão em voga na década de oitenta. Isso porque, para BECK, além de vagos, termos como pós-industrialismo e pós-modernismo dariam a entender que a modernidade teria chegado ao fim. Ele prefere tratar da questão como "uma quebra dentro da modernidade" 28 , em que os contornos da sociedade industrial teriam sido sobrepostos aos poucos por características de uma sociedade de risco. A diferença entre as duas formas de sociedade pode ser explicitada a partir de uma mudança de pesos: na sociedade industrial, a lógica da produção de riquezas dominaria a lógica da produção de riscos, relação que se inverteria na época atual. Isso significa dizer que a produção de riscos não pode mais ser entendida como efeito colateral da produção de bens - ela passa a ser constitutiva dos avanços tecnológicos e ganha uma dimensão ainda mais importante com a globalização. Isso

27 MARTINS-COSTA, Judith. "Reflexões sobre o princípio da função social dos contratos". Revista Direito GV, vol. 1, n. 1. São Paulo: FGV, 2005, p. 53.

28 BECK, Ulrich. Risk Society: towards a new modernity. Londres: Sage Publications, 1992, p. 9. Para outra visão, também motivada pela abordagem do risco na sociedade industrial, ver GIDDENS, Anthony. The Consequences of Modernity. Stanford : Stanford University Press, p. 45-53. 
porque os riscos atuais não estão mais confinados a certos grupos de pessoas ou localidades territorialmente delimitadas.

Utilizar o conceito de risco para indicar a instabilidade que daria o tom de novidade aos nossos tempos não significa dizer que as épocas anteriores eram completamente estáveis e que nelas o risco era inexistente. Apesar de o risco não ser uma invenção da modernidade, BECK identifica uma mudança significativa em seu sentido. Para o autor, anteriormente o risco era parte de uma esfera pessoal e ganhava ares de aventura em trajetórias individuais. ${ }^{29}$ Apesar de partir de uma matriz teórica distinta, LUHMANN responde a essa questão de forma semelhante: em outras épocas, o risco dizia apenas respeito àquele que fazia uma escolha e que, assim, tinha uma experiência direta dos perigos e das possíveis consequências de sua ação individual. ${ }^{30}$ Para ambos os autores, a mudança para a sociedade atual não seria apenas de escala ou de extensão: além de disseminado, o risco global escapa à percepção.

Para BECK, isso ocorre porque o desenvolvimento da racionalidade instrumental baseada no cálculo entre meios e fins vem acompanhado do aumento de seu contrário, ou seja, da incalculabilidade de suas consequências. Se o risco escapa à percepção, ele também escapa a qualquer medida, o que faz com que consequências desconhecidas e involuntárias passem ao primeiro plano. ${ }^{31}$ Para LUHMANN, essa incalculabilidade pode ser traduzida a partir da noção de "futuras gerações": as relações sociais não são apenas pensadas pelo esquema eu-outro, mas são ampliadas para eu-outro que ainda não nasceu. ${ }^{32}$ Isso mostra como os impactos do risco ultrapassam gerações e evidencia a dificuldade de uma percepção direta ou de um cálculo factível.

O novo sentido de risco tem importantes consequências para o direito e especialmente para o direito de seguro. O primeiro ponto levantado por BECK é o da discrepância entre a base normativa do cálculo do risco e as dimensões básicas das ameaças. ${ }^{33}$ Podemos facilmente pensar na definição do prêmio em um contrato de seguro como essa base normativa de cálculo. $\mathrm{O}$ descompasso apontado pelo autor pode chegar a casos extremos: segundo BECK, acidentes atômicos não são passíveis de ser segurados seus efeitos afetam até mesmo aqueles que não estavam vivos à época e não haveria um critério possível para calcular o risco de um evento dessa magnitude. E isso nos leva ao

29 Idem, p. 21.

30 LUHMANN, Niklas. Soziologie des Risikos. op. cit., p. 119.

31 BECK, Ulrich. Risk society: towards a new modernity. op. cit., p. 22.

32 LUHMANN, Niklas. Soziologie des Risikos. op. cit., p. 5.

33 BECK, Ulrich. Risk society: towards a new modernity. op. cit., p. 22. 
segundo ponto levantado pelo autor: as categorias jurídicas de regulação teriam ficado ultrapassadas diante dessas transformações. Os padrões para medir o normal e o desviante em termos de risco ainda estão, na visão do autor, atrelados à sociedade industrial. ${ }^{34}$ Noções como "trabalho estável" ou "família ordenada", apenas para citar exemplos, perdem seu sentido prescritivo quando a instabilidade do trabalho passa a ser a regra ou quando o modelo familiar tradicional entra em crise. $\mathrm{O}$ direito também passa por uma crise de normatividade com essas mudanças estruturais. Esse aspecto é enfatizado por François EWALD:

Generalização da noção de risco, objetivação da insegurança como acidente, proliferação das instituições de seguro que duplicam e progressivamente substituem os antigos procedimentos jurídicos cada vez mais inadequados frente à nova problemática da responsabilidade, decididamente nós vivemos a era que se poderia denominar das "sociedades securitárias". ${ }^{35}$

Mas isso não significa afirmar que o direito - ou especificamente o direito do seguro - se torna irrelevante diante de riscos imensuráveis. Para BECK, as profissões jurídicas passam a ter uma posição social central justamente porque, ainda que as leis não acompanhem as mudanças, os chamados operadores do direito são os principais responsáveis pela determinação do risco. ${ }^{36}$ A definição do risco pelo juiz, pelo legislador, pelas partes num contrato ou pelo formulador de políticas públicas é vista como o exercício de um poder. E isso ganha especial relevância se atentarmos para a desigualdade na forma com que o risco atinge as pessoas. Nos termos de BECK, há vencedores e perdedores na definição do risco. ${ }^{37}$

Em sua releitura da sociedade do risco como sociedade mundial do risco (world risk society), o autor introduz novas distinções conceituais, como entre risco e catástrofe, ou entre risco e percepção do risco, anotando que esta última varia conforme a compreensão cultural que se tem do risco. Um dos objetivos do autor com essas distinções é tratar dos novos fenômenos associados ao terrorismo suicida transnacional e compará-los aos riscos ambientais e econômicos globais.

34 Idem, p. 134.

35 EWALD, François. L'État Providence. Paris: Bernard Grasset, 1986, p. 20: “Généralisation de la notion de risque, objectivation de l'insécurité comme accident, prolifération des institutions d'assurances doublant et remplaçant progressivement les anciennes procédures juridiques de plus en plus inadaptées à la nouvelle problématique de la responsabilité, décidément nous sommes à l'âge de ce qu'on pourrait appeler les societés assurantielles".

36 BECK, Ulrich. Risk society: towards a new modernity. op. cit., p. 23.

37 Idem. 
De acordo com o autor, enquanto a catástrofe é determinada socialmente, no tempo e no espaço, o risco consiste na antecipação da catástrofe. Coloca-se no plano da possibilidade de ocorrências futuras que nos ameaçam e deixa de ser meramente especulativo à medida que se concretiza. Tornando-se um perigo constante, o risco de eventos futuros, como um ataque terrorista ou a explosão de uma usina nuclear, passa a moldar nossas expectativas, alojando-se em nossas mentes e guiando nossas ações. O risco se revela como força política que transforma o mundo. Não seriam os eventos em si, mas antes a maneira de lidar antecipadamente com eles, de maneira globalizada, que estaria ameaçando as instituições democráticas ocidentais por meio da restrição às liberdades individuais e outras. ${ }^{38}$

Não importa, acrescenta o autor, que o mundo hoje seja objetivamente mais seguro do que outrora: a antecipação de desastres e catástrofes nos obriga a adotar medidas preventivas ou de precaução. Esta se tranforma numa das mais preeminentes tarefas do Estado, ainda que suas autoridades, confinadas ao horizonte do Estado-nação, não disponham ainda de instrumentos eficazes para lidar com riscos globais. Os riscos globais, no entanto, malbaratam a distinção entre risco e percepção do risco em que se apoia a ciência do risco. Em relação aos riscos globais, não se pode dizer que sua compreensão objetiva e racional, através de sua identificação estatística e da formulação de modelos e prognósticos, seja mais precisa do que a das pessoas comuns. A antecipação de catástrofes como as mencionadas resiste de maneira geral ao métodos científicos de cálculo. ${ }^{39}$

Isso representa, por um lado, uma limitação ao emprego da técnica clássica do seguro, consistindo, por outro, num estímulo a seu desenvolvimento, assim como ao desenvolvimento de outros instrumentos sociais para a gestão dos riscos. ${ }^{40}$ Tom BAKER

\footnotetext{
${ }^{38}$ BECK, Ulrich. World at Risk. Cambridge: Polity, 2009, p. 9-10. A paradoxal criação de novos riscos em razão do controle dos antigos riscos é também assinalada, ainda que de maneira embrionária, por Peter Bernstein em sua conhecida obra. BERNSTEIN, Peter L. Desafio aos Deuses. Rio: Elsevier, 23ª ed., 1997, p. 337.

${ }^{39}$ Idem, p. 11-12. O mesmo ponto é realçado em FISCHHOFF, Baruch, KADVANY, John. Risk: A very short introduction. Oxford: Oxford University Press, p. 88 e ss., em que discutem como tomar decisões frente aos riscos que decorrem dos avanços tecnológicos.

${ }^{40}$ Para uma discussão das transformações do seguro e de outras técnicas vocacionadas a lidar com ele na sociedade contemporânea, ver BAKER, Tom, SIMON, Jonathan. Embracing Risk: The Changing Culture of Insurance and Responsibility. Chicago: University of Chicago Press, 2002. A Organização para a Cooperação e o Desenvolvimento Econômico, a propósito, vem promovendo a formação de uma rede internacional para a gestão financeira de catástrofes de larga escala, cujos trabalhos iniciais foram relatados em OECD. Financial Management of Large-Scale Catastrophes. Paris: OECD Publications, 2008. A estabilização dos riscos financeiros em escala global vem sendo discutida no âmbito de diversas organizações internacionais, como o Fundo Monetário Internacional, como analisa JOHNSON, Omotunde E. G. (orgs.). Financial Risks, Stability, and Globalization. Washington: International Monetary Fund Publications Services, 2002.
} 
propõe uma ampliação da visão sobre o seguro que não esteja limitada a um simples mecanismo de pulverização de risco. Para o autor, o risco tem de ser abraçado (embracing risk), pois o valor do seguro se assenta antes de tudo na "imaginação" que se constrói a respeito do seu papel. Os tribunais frequentemente enfatizam que se deve levar em conta a "expectativa adequada do segurado" (reasonable expectation of the insured), consistindo a propaganda que se faz do seguro, e que evoca uma visão muito diferente da adotada quando se nega um sinistro, elemento relevante para determinar essa expectativa. ${ }^{41} \mathrm{O}$ autor não deixa de reconhecer, no entanto, que a compreeensão do seguro como mecanismo de pulverização deverá remanescer central, mesmo ante a erosão do paradigma da solidariedade, com o desmantelamento do Estado Providência a partir dos anos $1980 .{ }^{42}$

Como mostrou François EWALD em seu trabalho clássico já citado, em que reconstrói a história do Estado Providência a partir do século XIX com foco na emergência do risco como meio dominante de compreender e intervir no mundo, a visão, as formas, as instituições e as tecnologias securitárias ajudam a explicar de que maneira o seguro pôde funcionar como uma forma de gestão governamental. ${ }^{43}$ Para o autor, o risco é um produto da tecnologia securitária. A aplicação da estatística a dados agregados produziu - como ainda produz - uma representação do risco como objeto que pode ser conhecido e distribuído. O caso paradigmático estudado por EWALD foi o do desenvolvimento do seguro de acidente do trabalho, que buscava racionalizar os acidentes na indústria, sempre que possível, pela prevenção da ocorrência de lesões e pela pulverização dos custos dos acidentes que não pudessem ser prevenidos. ${ }^{44}$

41 BAKER, Tom. "Risk, Insurance, and the Social Construction of Responsibility". In: BAKER, Tom, SIMON, Jonathan. Embracing Risk: The Changing Culture of Insurance and Responsibility.op. cit., p. 33-48.

${ }^{42}$ São diversos os esforços que vêm sendo desenvolvidos para mensurar os novos riscos, valorizando-se a percepção do risco pelas pessoas comuns e buscando-se superar o hiato entre essa visão e a dos experts. Destacam-se nesse sentido as obras coletivas editadas por Paul Slovic: SLOVIC, Paul. The Perception of Risk. Londres: Earthscan, 2000 e SLOVIC, Paul. The Feeling of Risck: New Perspectives on Risk Perception. Londres: Earthscan, 2010.

${ }^{43}$ O tema é muito bem desenvolvido em ERICSON, Richard V., DOYLE, Aaron, e BARRY, Dean. Insurance as Governance. op. cit. Os autores consideram o seguro um elemento-chave da política econômica, destacando suas dimensões econômica, social, jurídica, cultural e política, para em seguida demonstrarem que o seguro compartilha com o Governo, em alto grau, objetivos de segurança e solidariedade através de pools, técnicas de governo à distância etc.

${ }^{44}$ EWALD, op. cit., passim. A abordagem do seguro como tecnologia do risco, como um esquema da racionalidade, uma forma de ordenar a realidade, e do risco como uma construção securitária, dependente de como o perigo com que nos defrontamos é analisado, de como o evento é considerado, é retomada pelo autor em textos posteriores como EWALD, François. Insurance and Risk. In: BURCHELL, Graham, GORDON, Colin, MILLER, Peter (orgs.). The Foucault Effect: Studies in Governmentality. Chicago: University of Chigago Press, 1991. p. 197-210. Os trabalhos de François Ewald colocam-se no espaço de interação entre indivíduo e Estado para o qual Michel Foucault chamou atenção em suas palestras sobre a governabilidade, parte delas incluída na obra aqui citada. Cf. p. ex. Governmentality. In: BURCHELL, Graham, GORDON, Colin, MILLER, Peter (orgs.). The Foucault Effect: Studies in Governmentality. op. cit., p. 87-104. 
Não tardou, no entanto, para que a literatura, em particular os trabalhos seguintes do próprio EWALD, registrasse a ruptura dessa lógica social de governança e apresentasse outras abordagens, em especial a de políticas que enfatizassem o indivíduo, ligadas à tradição liberal. Entretanto, essa ênfase no indivíduo tinha por consequência fazer com que ele suportasse cada vez mais riscos, em prejuízo da socialização do risco que sempre informou a indústria securitária.

A assunção do risco, através do seguro ou de outras ferramentas, pressupõe uma estratégia de gestão governamental fundamentalmente no nível do Estado, que envolve a atuação de instituições sociais intermediárias como companhias de seguro, empregadores, bancos e operadoras de planos de saúde médico-hospitalar. ${ }^{45}$ Como alertam Mary DOUGLAS e Aaron WILDAVSKY, o diálogo é eminentemente político: a definição sobre como utilizar os recursos à disposição não é uma decisão de natureza técnica. As fontes de risco, no entanto, são virtualmente infinitas em número, sujeitando-se apenas à fertilidade da imaginação e não há limite sobre o que pode ser gasto para eliminá-los. ${ }^{46}$

Todavia, para autores como François EWALD, a emergência dos riscos globais é um dos fatores que têm engendrado um novo paradigma. Assim como o paradigma da responsabilidade, dominante ao longo do século XIX, associado ao liberalismo e baseado em obrigações morais, foi substituído pelo paradigma da solidariedade, associado ao Estado Providência e baseado numa considerável ampliação de obrigações legais, opera-se na atualidade a substituição deste pelo que o autor denomina de paradigma da segurança. Uma nova economia de direitos e deveres vem se conformando e a linguagem do risco, utilizada para descrever cientificamente todos os tipos de insegurança - cedendo espaço à incerteza e alimentada pelas dúvidas que as novas ciências colocam ao conhecimento científico moderno - vem se confrontando com a noção de precaução. ${ }^{47}$

\footnotetext{
${ }^{45}$ McCLUSKEY, Martha. Rhetoric of Risk and the Redistribution of Social Insurance. In: BAKER, Tom, SIMON, Jonathan. Embracing Risk: The Changing Culture of Insurance and Responsibility.op. cit., p. 146166.

${ }^{46}$ DOUGLAS, Mary, WILDAVSKY, Aaron. Risk and Culture: An essay on the selections of technological and environmental dangers. Berkeley: University of California Press, 1983, p. 174 e ss.

${ }^{47}$ EWALD, François. The return of Descartes's malicious demon: An outline of a Philosophy of Precaution. In: BAKER, Tom, SIMON, Jonathan. Embracing Risk: The Changing Culture of Insurance and Responsibility. op. cit., p. 273-299. O autor não deixa de invocar a formulação do princípio da precaução por Hans JONAS, que adaptou o imperativo categórico kantiano a um novo tipo de ação humana: "Age de tal maneira que os efeitos da sua ação sejam compatíveis com a permanência de uma vida autenticamente humana na Terra" (Act so that the effects of your action are compatible with the permanence of an authentically humane life on earth). Cf. JONAS, Hans. The Imperative of Responsibility. Chicago: University of Chicago Press, 1984. p. 5.
} 
Para EWALD, no entanto, o paradigma da segurança, ligado ao princípio da precaução, não deixará de se constituir num paradigma para o seguro, que deverá assumir novas formas para atender às condições culturais que ora se impõem. Nas palavras do autor:

\begin{abstract}
A precaução começa quando decisões devem ser tomadas em razão e no contexto da incerteza científica. As decisões são tomadas, portanto, não num contexto de certeza, nem mesmo de conhecimento disponível, mas de dúvida, suspeita, premonição, mal-estar, mudança, desconfiança, medo e ansiedade. Há em certa medida um risco além do risco, de que não se tem nem se pode ter o conhecimento ou a medida. O conceito de risco do desenvolvimento se localiza dentro do limite dessa nova figura da prudência. ${ }^{48}$
\end{abstract}

O autor considera que a forma extrema da ideia de precaução é dada pelo conceito de risco do desenvolvimento, que acentua todos os paradoxos e dificuldades do mundo contemporâneo. Um evento indetectável ou imprevisto, que só vem a ser conhecido depois de determinado período de tempo, pressupõe um conhecimento científico que não estava disponível. ${ }^{49}$ Não obstante, acrescenta EWALD, pode-se antecipar a transformação do conhecimento, através de um novo relacionamento com a ciência e a engenharia. Não se pode mais viver a ilusão de que a ciência pode controlar a si mesma. É necessário reconhecer o dinamismo da ciência e a relatividade essencial do conhecimento. A ciência aumenta nosso poder e capacidade de intervenção no mundo sem no entanto reduzir a incerteza que ela própria gera. A novidade do risco do desenvolvimento, em outros termos, é a de que ele necessariamente se revela a posteriori, apresentando muitas vezes uma natureza diferente, estranha ou oposta à que se supunha. Exemplo emblemático é o drama da transfusão de sangue, ocorrido no início dos anos 1990 na França: o sangue era submetido a um procedimento de aquecimento porque se acreditava à época que o calor tornava o vírus da AIDS inativo. ${ }^{50}$

O princípio da precaução, portanto, está na agenda da sociedade do risco ou de uma world risk society em que a exposição ao risco se tornou a característica que define os grupos sociais. Novos riscos, como a doença da vaca louca, a chuva ácida, a fissão nuclear e os riscos inerentes aos organismos geneticamente modificados, de acordo com Ulrich

\footnotetext{
${ }^{48}$ Idem, p. 294: "Precaution starts when decisions must de made by reason of and in the context of scientific uncertainty. Decisions are therefore made not in a context of certainty, nor even of availabe knowledge, but of doubt, suspicion, premonition, foreboding, challnge, mistrust, fear, and anxiety. There is to some extent a risk beyond risk, of which we do not have, nor cannot have, the knowledge or the measure. The concept of risk of development is found within the limit of this new figure of prudence."

${ }^{49}$ Idem, p. 289.

${ }^{50}$ Idem, p. 290.
} 
BECK, estão redesenhando as estratégias dominantes de seguridade. Essa apreciação, como o próprio autor reconhece, é muito próxima à do citado François EWALD, para quem o risco do desenvolvimento demanda, na síntese de BECK, entre outras medidas, a criação de esquemas de seguros e a regulação da economia e do meio ambiente em termos de criação de seguridade. ${ }^{51}$

O direito do seguro encontrou notável desenvolvimento quando passou a ser visualizado sob a ótica do princípio da solidariedade, mostrando as limitações do princípio da responsabilidade, questionando o direito liberal ao revelar a importância da atuação do Estado no setor e provocando mudanças significativas no campo do Direito das Obrigações. ${ }^{52}$ Esse descompasso entre as categorias jurídicas e as mudanças no sentido do risco enfatizado pelos conceitos da sociologia do risco sintetizados anteriormente será analisado de forma detida no tópico seguinte, que tratará do direito de seguro como resposta à insuficiência da categoria jurídica da responsabilidade civil.

\subsection{Direito do seguro como resposta à insuficiência da responsabilidade civil}

O acidente deixou de ser apreendido a partir da infortunística das relações entre os homens e destes com a natureza pela ciência e pela sociedade em geral. Os conflitos não podem ser solucionados concretamente com base nas regras de exclusão e atribuição de responsabilidades. Além disso, não há como indenizar as vítimas mediante o recurso aos patrimônios dos responsáveis porventura identificados pela teoria jurídica.

A sociedade passou por fortes mudanças e uma "revolução" desenvolveu a atuária e a estatística, técnicas que possibilitaram a identificação, a compreensão, a classificação, a quantificação e a medição precisas dos riscos e das necessidades econômicas produzidas pelos sinistros, enfim, a determinação do grau de sujeição da sociedade ao acidente. Tomando emprestada a locução utilizada por DÍEZ-PICAZO, o reduzidíssimo “campo de álea" do seguro também foi protegido com a elaboração da técnica do resseguro e, a deste, com o surgimento da técnica de retrocessão.

É nesse contexto que o direito de seguro deve ser entendido como uma resposta às

\footnotetext{
${ }^{51}$ BECK, Ulrich. "Risk Society Revisited”. In: ADAM, Barbara, BECK, Ulrich, VAN LOON, Joost (orgs.). The Risk Society and Beyond: Critical issues for social theory. Londres: Sage Publications, 2007, p. 225226.

52 Sobre o tema, cf. PIZA, Paulo Luiz de Toledo. Contrato de Resseguro: Tipologia, Formação e Direito Internacional. São Paulo: EMTS, 2002, p. 23-37.
} 
insuficiências das categorias dogmáticas da responsabilidade civil. As dificuldades com o conceito tradicional de culpa subjetiva se verificaram dentro dos próprios limites do debate jurídico sobre responsabilidade. Sob o impulso de exigências econômicas, sociais e tecnológicas, surgem novas teorias e a jurisprudência acaba acolhendo-as e passa a ampliar o conceito de culpa ou mesmo a dispensar sua verificação. Novas leis caracterizam a responsabilidade civil extracontratual independentemente da verificação da culpa. A "culpa presumida", as presunções "juris et de jure", a "responsabilidade legal" ou "objetiva", a "teoria do risco criado" e do "risco integral" serão os pés-de-cabra a romper os estreitos limites da teoria clássica da responsabilidade.

A verdadeira explosão do conteúdo da responsabilidade civil - que alguns reclamam ser invasão do instituto, enquanto outros proclamam tratar-se de verdadeira integração - não é outra coisa senão o evidente sintoma de uma profunda revolução do direito.

Ainda que seu conteúdo tenha passado por fortes transformações nos últimos tempos, ainda há limitações significativas. O ponto de estagnação da responsabilidade civil, mesmo consideradas as mudanças em sua concepção clássica, não é outro senão a incapacidade de todo e qualquer instituto jurídico de promover a reparação econômica, especialmente no mundo contemporâneo - ou, se quisermos, na sociedade do risco.

A responsabilidade civil, com o incrível desenvolvimento dos acidentes, dá mostras claras de insuficiência. $\mathrm{O}$ acidente não tem mais necessariamente um responsável ou, muitas vezes, para efeito de indenização dos prejuízos, pouco importa quem é o responsável. A questão que persiste: como indenizar as vítimas se o patrimônio do responsável não se revelar suficiente? E como evitar o risco de debacle das unidades produtivas "responsáveis" que pode sobrevir mesmo para os mais "privilegiados patrimônios" em consequência da efetiva reparação das vítimas?

A questão, localizada evidentemente na intersecção entre economia e direito, só encontra saída jurídica além do direito da responsabilidade. Conforta-se em seu sucedâneo, o direito da solidariedade: o direito do seguro. Apenas o seguro é capaz de prover indenizações de dimensão compatível com os efeitos da infortunística moderna.

A nova demanda social e a evolução da ciência redefiniram o seguro. Ele se transformou num instrumento de precisão, indispensável para a solidarização que, a seu 
turno, passou a ser identificada como objetivo fundamental das sociedades que se adjetivaram por "securitárias", como observa EWALD. ${ }^{53}$

Provendo meios materiais para eliminar os efeitos dos acidentes, o que nenhuma técnica jurídica jamais poderia conseguir, o seguro fez-se uma espécie de sucedâneo da teoria da responsabilidade civil. Foi um grande passo, pois a teoria jurídica, que sempre teve na responsabilidade civil um dos campos de maior desenvolvimento e renovação dogmática, não conseguia ir além de um efeito social muito restrito que é a identificação do responsável e a possibilidade de eventual utilização do seu patrimônio individual para indenizar a vítima. Chegou-se à concreta indenização dos prejudicados pelos acidentes no meio social. $^{54}$

Entre os juristas brasileiros foi J. J. Calmon de PASSOS quem melhor registrou essa passagem:

Os danos que decorrem de atividades cuja licitude foi admitida em proveito (teoricamente) de todos, consequentemente em benefício da convivência social, em que pese seu componente de risco, devem ser por essa mesma sociedade suportados. Revelou-se induvidoso que se admitir a responsabilidade pelo risco, de matriz social, mantendo-se a antiga técnica de ressarcimento às custas do patrimônio individual do responsável, significaria inviabilizar-se a atividade produtiva, incapaz de arcar com o ressarcimento dos danos inerentes a essa mesma atividade, caso conservada a velha perspectiva. Para se tornar operacional a teoria do risco, sem disfuncionalidade, impôs-se a solução pelo seguro, que institucionaliza, em termos técnicos, o imperativo da solidariedade numa sociedade de riscos. O que surgiu como um contrato entre pessoas, no qual uma delas assumia os riscos de indenizar a outra por força de algum sinistro que viesse a atingir o seu patrimônio ou a sua pessoa, bem mais próximo do jogo e da aposta que de algo relacionado com algum interesse social relevante, o que antes fora assim pensado, tornou-se uma técnica a serviço do interesse geral, mais adequadamente definível como seguridade social ou segurança social, publicizando-se ou socializandose, se assim preferir. Deixou de ser possível, por conseguinte, entender-se a atividade securitária como de natureza estritamente privada, passando a ser vista, em muitas de suas manifestações, como vinculada ao interesse geral, retirada do campo da pura autonomia da vontade, passando a ser regulada, de forma cogente e minuciosa, pelo Poder Público. Os negócios que formaliza entram na categoria também nova dos chamados contratos de massa. Relações jurídicas nas quais o menos relevante é o sujeito que

53 EWALD, François. L'Etat Providence. op. . cit.

54 Vide LAMBERT-FAIVRE, Yvonne. L'evolution de la responsabilité civile d'une dette de responsabilité a une créance d'indemnization. Revue Trimestrielle de Droit Civil, Paris, 1987; MESSINA DE ESTRELLA GUTIERREZ, Graciela Nora. La responsabilidad civil en la era tecnológica. Buenos Aires: Abeledo-Perrot, 1989, p. 218-219. 
contrata e de quase nula relevância as motivações da declaração de vontade que formaliza. ${ }^{55}$

Tratada essa dimensão do seguro, o próximo item analisará a questão da comutatividade do contrato de seguro a fim de evidenciar mais um nível de sua socialidade.

\subsection{Comutatividade do contrato de seguro}

A dimensão social do contrato de seguro também se evidencia na discussão sobre sua comutatividade. Isso porque é por meio dos contratos de seguro que uma seguradora passa a reunir e administrar coletividades submetidas ao risco. O preço determinado no contrato tem de ser proporcional ao risco e só é possível estabelecê-lo a partir da massa de segurados. Não se trata, portanto, de preço livre cobrado individualmente, mas sujeito a variações para baixo ou para cima de acordo com o risco a que está submetida toda a massa ou coletividade de segurados. A perspectiva da comutatividade permite entender o contrato de forma integrada à operação.

Assim, não há como nem porque comparar os contratos que conformam os seguros, sob nenhum ângulo e para nenhum efeito, com o jogo ou com a aposta. Distanciam-se também dos negócios jurídicos agrupáveis no conjunto dos aleatórios. Isso porque os seguros exigem elevado grau de comutação que provoca consequências importantes para as partes, o conjunto de segurados e beneficiários, e para a sociedade como um todo. ${ }^{56}$

55 CALMON DE PASSOS, J.J. O risco na sociedade moderna e seus reflexos na teoria da responsabilidade civil e na natureza jurídica do contrato de seguro. In: I Fórum de Direito do Seguro "José Sollero Filho" (2000), São Paulo, Anais, São Paulo: EMTS e IBDS, 2001, p. 11-19.

${ }^{56}$ Vide TZIRULNIK, Ernesto. A constrição judicial de bens garantidores de provisões ou reservas técnicas. São Paulo: ETAD, 1998. TZIRULNIK, Ernesto. Apontamentos sobre a operação de seguros. Revista Brasileira de Direito de Seguros, Rio de Janeiro, n. 1, 1997, p. 13-35. TZIRULNIK, Ernesto, LUIS, Alessandro S. Octaviani. Regulação de Sinistro (ensaio jurídico), $3^{\mathrm{a}}$ ed., São Paulo: Max Limonad, 2001, p. 45-60. TZIRULNIK, Ernesto, CAVALCANTI, Flavio de Queiroz Bezerra, PIMENTEL, Ayrton. Contrato de Seguro - de acordo com o Novo Código Civil Brasileiro. $2^{\mathrm{a}}$ ed., São Paulo: Revista dos Tribunais, 2003, p. 30-31. FRANCO, Vera Helena de Mello. O contrato de seguro In: BITTAR, Carlos Alberto (org.). Novos Contratos Empresariais. São Paulo: RT, 1990, p. 189 e ss. FRANCO, Vera Helena de Mello. Contratos Direito Civil e Empresarial. 2a ed., São Paulo: RT, 2011, p. 285-288. PASSOS, José Joaquim Calmon de. O Risco na sociedade moderna e seus reflexos na teoria da responsabilidade civil e na natureza jurídica do contrato de seguro. In: I Fórum de Direito do Seguro "Jose Sollero Filho", Anais. São Paulo: Max Limonad, 2001, p. 13. BORGES, Nelson. A teoria da imprevisão no direito civil e no processo civil. São Paulo: Malheiros, 2002, p. 276 e ss. COELHO, Fábio Ulhoa. Curso de Direito Comercial. vol. III, $3^{\text {a }}$ ed., São Paulo: Saraiva, 2002, p. 148. POLIDO, Walter Antonio. Contrato de Seguro: novos paradigmas. São Paulo: 
É justamente essa relevância da comutatividade ínsita à empresa e a cada um dos contratos de seguro, sem o que serão desfuncionalizados técnica, econômica e socialmente, que dá procedência à "operação anti-aleatória de luta coletiva contra o infortúnio", ainda que a própria LAMBERT-FAIVRE tenha dissociado os contratos da empresa em busca de uma romântica aleatoriedade, empresa polêmica que, a rigor, já fora bem resolvida no Brasil, na década de 1960, por Fábio Konder COMPARATO. ${ }^{57}$

A dissociação entre a empresa e os contratos através dos quais esta se materializa, como enfatiza COMPARATO, esvazia a relação obrigacional de seguro, pois, "fora dessa organização mutualística, tecnicamente estruturada, não há propriamente seguro, mas um ajuste bilateral assemelhado ao jogo ou à aposta."

Há inúmeras definições para os contratos aleatórios, matéria que deve ser vista com grande atenção, pois, muito embora constitua um capítulo importante para a discussão a respeito do rebus sic stantibus, da teoria da imprevisão e de sua incidência sobre o pacta sunt servanda, costuma ser utilizada para atribuir maior liberdade à predisposição das condições contratuais e para a precificação dos seguros.

Luis DÍEZ-PICAZO observa que a distinção entre contratos aleatórios e comutativos "é tradicional" na literatura jurídica, embora seus "perfís não sejam suficientemente claros". 59

Após apresentar as diversas variações da doutrina a respeito, adere à corrente que entende que "o negócio jurídico é aleatório quando o azar intervém no desenvolvimento do contrato e no jogo dos sacrifícios, precisamente porque ambas as partes quiseram o contrato dessa maneira e não de outras". Segundo esse ponto de vista, "a incerteza ou o azar serão a própria causa da obrigação ou, pelo menos, se integrarão dentro dela."

Esse pensamento exige uma "gradação entre diferentes tipos ou espécies de áleas, precisamente para buscar o limite ou o ponto de fronteira entre os contratos comutativos e os contratos aleatórios." Nessa linha, existiriam duas espécies básicas de álea. Uma é a normal, como o risco derivado das oscilações do mercado que pode tornar uma prestação

Roncarati, 2010, p.129. BUSTAMANTE FERRER, Jaime, URIBE OSORIO, Ana Inés. Principios jurídicos del seguro. Bogotá: Temis, 1996, p. 14-17.

57 Vide COMPARATO, Fábio Konder. O Seguro de Crédito. São Paulo: RT, 1968, p. 136; COMPARATO, Fábio Konder. "Obrigações de meio, de resultado e de garantia." In: Ensaios e Pareceres de Direito Empresarial. Rio de Janeiro: Forense, 1978, p. 521-539.

58 COMPARATO, Fábio Konder. Seguro - Cláusula de rateio proporcional - Juridicidade. Revista de Direito Mercantil, n. 7, São Paulo: RT, 1972, p. 110.

59 DÍEZ-PICAZO, Luis. Fundamentos del derecho patrimonial, vol. I, $6^{a}$ ed., Pamplona (Espanha): Civitas, 2007, p.104.

60 Idem, p. 107 
mais ou menos onerosa, sendo que, se não gerar um "desequilíbrio básico", o contrato continuaria comutativo com um "campo de alea normal". A outra espécie seria a convencional, que é "o que excede ao normal”, e que as partes introduzem no negócio que, sem embargo, "continua possuindo uma estrutura ou uma natureza comutativa". 61

Assim DÍEZ-PICAZO conclui que o contrato aleatório é uma espécie de "hipótese residual” e apresenta sua definição: "é aquele negócio em que a álea é querida pelas partes como momento essencial e necessário da função do contrato que incide diretamente sobre ele como causa típica, de modo que por vontade das partes se dá vida a uma causa aleatória." 62

Como sói acontecer, o seguro é tout court confundido no bojo dos jogos de azar e da renda vitalícia e surge como exemplo de negócio aleatório não condicional. DÍEZPICAZO explica que a incerteza desses negócios "aleatórios" não está subordinada a uma condição, referindo-se sua incerteza "às prestações a executar ou a sua respectiva relação". 63

Sem análise mais aprofundada, Vincenzo ROPPO inclui o seguro, ao lado do jogo, da aposta e da renda vitalícia, como exemplo de "contrato aleatório típico", isto é, aquele caracterizado pelo risco jurídico-econômico da prestação. ROPPO logicamente não desconhecia que a seguradora prestava "cobertura assecuratória contra o prêmio pago pelo segurado", mas não levou à balança o valor intrínseco que tem a prestação de garantia pela seguradora, fixando a atenção no risco a que está sujeita apenas a dívida de pagamento de indenização ou capital, dívida esta que obviamente depende, em cada contrato, da realização do risco e da prejudicialidade que este impuser ao interesse garantido. ${ }^{64}$

Por ora interessa ressaltar que o contrato aleatório, para ROPPO, é aquele sujeito a desequilíbrio, que possa premiar uma parte e penalizar a outra, porque a prestação de uma delas está exposta a risco, ainda que tenha uma "contraprestação correspectiva".

Em nossa doutrina, costuma-se definir que aleatório é o contrato em que "seguramente, é incerto o direito à prestação" 65 ou aquele em que a equivalência entre as prestações, "aproximada ou exata",66, pode ou não se verificar.

61 Idem, p. 107-108.

62 Idem, p. 108

63 Idem, p. 108.

64 ROPPO, Vincenzo. Il contratto. In: Trattato di Diritto Privato a cura di Giovanni Iudica e Paolo Zatti, $2^{\mathrm{a}}$ ed., Milão: Giuffré, 2011, p. 421-424.

65 GOMES, Orlando. Contratos. 26a ed., Rio de Janeiro: Forense, 2009, p. 88.

66 BEVILAQUA, Clóvis. Direito das Obrigações. Campinas: Red Livros, 2000, p. 256. 
No seguro, a prestação da garantia, sob pena de inadimplemento absoluto, e a de prêmio são necessariamente certas. Não se contrapõe o prêmio à indenização ou capital que porventura venha a ser devido em caso de sinistro. Ele deve ser contraposto à efetiva garantia, com lastro e determinação de atribuição patrimonial, de um interesse exposto a risco tecnicamente calculado e cuja variação, para além do "campo de álea normal", autoriza a resolução do contrato ou a exigência de uma sobreprestação por parte do segurado.

Com efeito, além de existir equivalência entre as prestações essenciais do contrato $^{67}$, determinadas alterações que aumentem ou reduzam a potencialidade de ocorrência e de severidade dos prejuízos igualmente aumentam ou diminuem o preço da garantia. ${ }^{68} \mathrm{E}$ isso ocorre porque se está ante um contrato que é tão essencialmente comutativo quanto é comutativa a própria empresa seguradora.

A integração entre a empresa e o contrato, e a conjuntura histórica que levou o seguro à artificial colação entre os aleatórios, constituem temas bem pesquisados pela doutrina, destacando-se nos estudos de língua portuguesa a demonstração feita por Paulo Luiz de Toledo PIZA. ${ }^{69}$

A dificuldade que os juristas encontram para perceber a comutação essencial entre as prestações do seguro decorre do fato de abstraírem as relações obrigacionais, examinando-as a partir da unidade aparente de cada contrato, alheias ao imenso complexo de interações que lhes serviu de base, informou cada princípio e cada regra.

Essa perspectiva, coberta pela capa ideológica da "natureza jurídica" e da "tradição" da literatura jurídica, principalmente a civilista, que se repete automaticamente na utilização do seguro, junto com a aposta e a renda vitalícia, como estereótipo dos aleatórios, conduz à sublimação da metodologia tipológica que, com segurança, afasta do contrato de seguro a incidência das regras jurídicas próprias aos chamados contratos aleatórios.

O simples fato de as leis atinentes aos contratos de seguro estabelecerem regras específicas de reequilíbrio para as prestações essenciais demonstra que a denominada "comutatividade do comércio jurídico" aqui incide de modo bastante acentuado. Assim, afasta a ideia de abstração da justiça dos preços ressaltada pelo pensamento liberal, em que

67 Caput do art. 757 do Código Civil Brasileiro (CCB), instituído pela Lei n. 10.406, de 10 de janeiro de 2002.

68 Ver, por exemplo, o parágrafo único do art. 766 e os arts. 770, 773, 778, 781, do CCB.

69 PIZA, Paulo Luiz de Toledo. Contrato de Resseguro. op. cit., capítulos III “Empresa e Resseguro" e V “A Obrigação de Garantia”, p. 119-1134 e 143-157, respectivamente. 
se confia ao mercado sua determinação, e faz o seguro atingir grau de concretização das equivalências que as próprias leis de consumo não promovem, limitando-se a regras de modificação de preço para os casos de vício de qualidade ou quantidade, vedação de aumentos sensíveis imotivados, respeito aos excepcionais tabelamentos, mas nunca exigindo a equivalência, pois isso corresponde a determinar o próprio preço ou, noutros termos, a pressupor "um preço objetivamente justo". ${ }^{70}$

Ao contrário do que ocorre com a quase totalidade dos negócios jurídicos onerosos, no seguro é pressuposta a formação coletiva de poupança para o funcionamento de um sistema de atribuições patrimoniais que, diante das prejudicialidades passíveis de ressarcimento, são traduzidas em "enriquecimentos negativos", isto é, as prestações não acrescem patrimônio, apenas evitam a diminuição patrimonial, no todo ou em parte. Essa característica que se traduz de modo positivo no chamado princípio indenizatório, permite compreender como o máximo grau de correspondência entre as prestações essenciais, prêmio e garantia é fundamental para a experiência securitária. ${ }^{71}$

A questão da comutatividade dos contratos que consubstanciam a "operação antialeatória" vem recebendo grande atenção na doutrina brasileira e louváveis esforços acadêmicos. $^{72}$

Ana Maria Blanco Montiel ALVAREZ, numa das pesquisas mencionadas, conclui pela comutatividade a partir do exame da causa-função:

A causa-função do seguro e a função econômico-individual das partes não se ligam à finalidade lucro (ou resultado) incerto, e o risco não é contemplado senão para ser mitigado ou eliminado. Além disso, não há prestações indeterminadas: ao tempo da conclusão do contrato, a prestação do segurado, o prêmio, é estipulada, tal como a contraprestação devida pelo segurador, a garantia, da qual a indenização decorre.

A caracterização da comutatividade é fundamental para compreender cada aspecto das prestações que, por si e conjuntamente, dão sentido à operação de seguro, esse método de distribuição de prejuízos $^{73}$ ou técnica de socialização dos riscos que é um fato social

70 DÍEZ-PICAZO, Luis. Fundamentos del derecho patrimonial. op. cit. p. 57-59.

71 DÍEZ-PICAZO, Luis. Fundamentos del derecho patrimonial. op. cit. p. 124.

72 Vide AZEVEDO, Luís Augusto Roux. A comutatividade do contrato de seguro. Dissertação de mestrado apresentada à Faculdade de Direito da Universidade de São Paulo, 2010. Ver também QUEIROZ, José Luiz de. Comutatividade no contrato de seguro. Dissertação de mestrado apresentada à Faculdade de Direito da Pontifícia Universidade Católica de São Paulo, 2007. Sobre a distinção entre os contratos aleatórios e comutativos, examinados segundo sua causa-função, ver ALVAREZ, Ana Maria Blanco Montiel. Partilha da Álea no Contrato de Resseguro. Dissertação de mestrado apresentada à Faculdade de Direito da Universidade Federal do Rio Grande do Sul, 2012.

73 VAUGHAN, Emmett J., ELLIOTT, Curtis M. Fundamentals of risk and insurance. $2^{\mathrm{a}}$ ed., Nova Iorque: John Wiley \& Sons, 1978, p. 18. Os mesmos autores: "From a social point of view, insurance is an economic 
nuclear de onde irradiam as manifestações de validade, eficácia e as diretrizes para a interpretação e execução dos vínculos individuais:

Por que um fato social? A resposta nos parece clara e simples. Os efeitos compensatórios perseguidos por meio do seguro não podem produzir-se se não existe comunidade de riscos dentro da qual seja possível diluir as indenizações a satisfazer em cada caso concreto. ${ }^{74}$

Como este fato social tem destacada função para a ordem econômica e correspectiva ordem jurídica - portanto ordem jurídica econômica, expressão que se constitui no continente dos princípios constitucionais que presidem a organização econômica rumo aos anseios sociais, políticos e culturais - é ressaltada a importância de compreender e preservar a integração jurídica entre a empresa seguradora e o contrato, e a conseguinte comutação ou equivalência entre as contribuições prestadas pelos segurados e o conteúdo e eficácia das garantias prestadas pelas seguradoras:

Este tema da função social do seguro nos obriga a efetuar uma rápida referência, ainda que mais não seja, à importância da instituição, seja para a economia nacional, enquanto permite a recolocação em marcha das fontes de produção, seja para a estabilidde social, ao mobilizar as fontes de trabalho afetadas pelo evento, seja para as economias individuais e privadas, uma vez que o seguro recupera para o sinistrado as perdas sofridas.

Daqui resulta que um sistema segurador idôneo, além de perseguir o baixo custo dos prêmios, deve fazer com que as indenizações cheguem ao segurado em tempo oportuno, para que o seguro cumpra com sua função social que o vitaliza e que constitui sua razão de ser. ${ }^{75}$

A importância da existência e funcionamento adequado do seguro não repercute exclusivamente sobre certos indivíduos, as partes dos contratos de seguro, ou grupos de indivíduos, como o grupo de segurados de uma mesma carteira de negócios homogêneos,

device for reducing and eliminating risk through the process of combining a sufficient number of homogeneous exposures into a group in order to make the losses predictable for the group as a whole." Idem, p. 24.

74 GARRIDO Y COMAS, J. J. Teoría general y derecho español de los seguros privados: teoría y práctica de los seguros privados. Barcelona: Consejo General de Agentes y Corredores de Seguros de España, 1986, p. 38: “¿Por qué un echo social? La respuesta nos parece clara y simple. Los efectos compensatorios que con el seguro se persiguen no pueden producirse si no existe una comunidad de riesgos dentro de la cual sea posible diluir las indemnizaciones a satisfacer en cada caso concreto."

75 MORANDI, Juan Carlos F.. El riesgo en el contrato de seguro: régimen de las modificaciones que lo agravan. Buenos Aires: Astrea, 1974, p. 27, nota 6: "Este tema de la función social del seguro nos obliga a efectuar una somera referencia, aunque más no sea, a la importancia de la institución, ya para la economía nacional, en cuanto permite la nueva puesta en marcha de las fuentes de producción, ya para la estabilidad social, al movilizar las fuentes de trabajo afectadas por el evento, ya para las economías individuales y privadas, en tanto el seguro recupera para el siniestrado las pérdidas sufridas. De aquí resulta que un sistema asegurador idóneo, a la par de perseguir el bajo costo de las primas, debe tratar que las indemnizaciones lleguen al asegurado en tiempo oportuno, para que el seguro cumpla con su función social que lo vitaliza y que constituye su razón de ser." 
mas atinge, necessariamente, toda a sociedade. $\mathrm{O}$ instrumento de solidarização econômica e social que é o seguro não apenas se informa como transporta as metas constitucionais de "mobilização da riqueza em favor do interesse geral". ${ }^{76}$

Isso não acontece apenas quando o acidente envolve interesses diretamente universais, como os que recaem sobre o meio ambiente. A experiência infortunística só pode ser compreendida a partir dessa dimensão coletiva ou social e o enfrentamento dos seus efeitos também exige o concurso comunitário, quer para a formação dos fundos em que se baseia, quer para justificá-los socialmente.

Em pronunciamento do Conselho Administrativo de Defesa Econômica, OCTAVIANI salienta a importância que o debate sobre a comutatividade assumiu no cenário jurídico brasileiro:

6.19. É com base nessas premissas técnicas e políticas que os principais estudiosos dessa densa regulação jurídica não hesitam em afirmar que "a comutatividade do contrato tem por base justamente o reconhecimento de que a prestação do segurador não se restringe ao pagamento de uma eventual indenização (ou capital), o que apenas se verifica no caso de sobrevir lesão ao interesse garantido em virtude da realização do risco predeterminado. $(\ldots)^{77}$

Discorrendo a respeito da função social e econômica do seguro, de sua instrumentalidade para a superação do subdesenvolvimento, e do regime de controle estatal que deve incidir sobre a empresa e os contratos, OCTAVIANI não descurou de ressaltar a relevância da compreensão da comutatividade, propondo que "um verdadeiro sistema orgânico de controle estatal" deve ocupar-se da "proteção simultânea e articulada da (i) obrigação de garantia e (ii) manutenção de reservas técnicas, que organizam e orientam qualquer atuação de interpretação/aplicação do direito no campo do seguro, (...)" 78

\subsection{Conclusões parciais}

O objetivo deste capítulo foi mostrar como não é possível conceber o seguro como uma relação restrita a indivíduos e a interesses particulares. A necessidade de considerar

\footnotetext{
${ }^{76}$ J. J. GARRIDO Y COMAS. Teoría general y derecho español de los seguros privados: teoría y práctica de los seguros privados.op. cit., p. 55.

77 CONSELHO ADMINISTRATIVO DE DEFESA ECONÔMICA. Ato de Concentração $\mathrm{n}^{\circ}$ 08012.005526/2010-39. Requerentes: Banco do Brasil S.A., BB Seguros Participações S.A. e Mapfre Vera Cruz. Relator Alessandro Luis S. Octavini. Voto publicado no Diário Oficial da União de 10.02.2012 n. ${ }^{\circ}$ 30, Seção 1, páginas 44, 45 e 46, p. 9.

78 Idem.
} 
sua socialidade foi indicada em diversos níveis. As origens históricas, a constituição fática do seguro a partir de uma comunidade que compartilha riscos, a ideia de uma sociedade do risco, a insuficiência dos conceitos dogmáticos conformadores da responsabilidade civil e o debate sobre a natureza comutativa do contrato de seguros apontaram para a imbricação entre seguro e coletividade. A dimensão da coletividade varia em cada um dos itens: de grupo à comunidade, da comunidade à sociedade como um todo.

O capítulo termina com análise inicial sobre o contrato de seguro e suas características. Essa questão será aprofundada no próximo capítulo, que trata da função social do contrato de seguro. 


\section{CAPÍtulo 2: A FUnÇÃo SOCIAL do CONTRATO DE SEGURO}

Deita-se por terra, assim, em nome da realização de justiça social-mas também do desenvolvimento - o princípio da liberdade de contratar, enquanto liberdade de configuração interna dos contratos. Tome-se como exemplo os contratos de loteamento, de seguro, as convenções condominiais, inúmeras fórmulas contratuais praticadas no mercado financeiro.

Eros Roberto Grau. Elementos de Direito Econômico. São Paulo: RT, 1981, p. 7879.

\subsection{O princípio da função social do contrato e o princípio da relatividade do} contrato

Mesmo após o advento do novo Código Civil, em 2002, ao debrucar-se sobre contrato de seguro, o enunciado que melhor representa a percepção corrente, própria do individualismo liberal, é o do revogado art. 1.432, do Código Civil de 1916, que dispunha: "Considera-se contrato de seguro aquele pelo qual uma das partes se obriga para com a outra, mediante a paga de um prêmio, a indenizá-la do prejuízo resultante de riscos futuros, previstos no contrato".

Segundo a literalidade desse dispositivo a relação securitária seria tipicamente bilateral ("uma para com a outra"), com prestações devidas entre as partes contratantes ("mediante a paga de um prêmio, a indenizá-la do prejuízo"), e a ideia de risco seria tomada na sua acepção mais tradicional ("riscos futuros"), paritariamente estabelecidos ("previstos no contrato").

Essa visão clássica de contrato, no âmbito dos seguros, é bastante desajustada diante da realidade. Embora muitos autores se esforcem para manter as velhas noções, a modernidade do tratamento do risco e a transindividualidade do contrato de seguro arrebentam as barreiras tradicionais.

A própria definição de risco, motivo da existência e do desenvolvimento dos serviços securitários, há muito não contém a futuridade como elemento essencial.

A mutação semântica do seguro fez com que esse passasse a abranger, além dos chamados riscos putativos, que se exemplificam pelo naufrágio ainda desconhecido do navio que acaba de zarpar e cuja viagem se assegura, ou pelas averbações simplificadas de 
transportes que já transcorreram e cuja infortunística foi consumada, também as lesões cumulativas sabidamente iniciadas antes da contratação do seguro, como são certas “doenças profissionais", como a surdez, por exemplo.

Além disso, os riscos seguráveis passaram a compreender qualquer situação de necessidade financeira que possa ser identificada durante a vigência da garantia do seguro, ainda que decorra de fatos precedentes, como acontece com as reclamações dos prejudicados por atos e fatos de responsabilidade do contratante do seguro ou por atos e fatos que possam vir a ser considerados de sua responsabilidade. O imenso território se descortina ainda mais quando olhamos para os seguros de responsabilidade civil do tipo “claims made" (ou "à base de reclamações") que cuidam de danos já causados, apenas pendentes de reclamação.

De outra banda, os riscos e os "acidentes" ou realizações dos riscos não mais devem corresponder necessariamente a imprevisibilidades, ou a insucessos, podendo consistir em fatos positivos e esperados, como a sobrevivência (seguro de sobrevida) e a demanda de formação escolar (seguro educação). Na atualidade, toda sorte de fatos que as técnicas contemporâneas permitem classificar como acidente ou sinistro, noutras palavras, que suscitem demandas financeiras representativas, estão contemplados na ampla classe de riscos asseguráveis.

Além da ampliação da definição de riscos asseguráveis e acidentes, também foi suplantada a concepção do seguro como contrato tipicamente bilateral a irradiar efeitos exclusivamente entre suas partes ou entre estas e terceiros instituídos beneficiários.

Não são os donos das coisas que "as asseguram" ou que seguram-se. Asseguramse, todos, pelos seus diferentes interesses patrimoniais com relação aos bens da vida determinados no contrato.

A nova concepção está ligada à compreensão de que o seguro garante pagamento pela lesão de interesses e não pelo dano às coisas, pessoas, direitos ou outros bens. Essa visão já se encontrava em estágio germinal no art. 678 do Código Comercial de $1850^{79}$, e aflorou no art. 757 do Código Civil de 2002. ${ }^{80}$

O art. 757 do Código Civil de 2002 já não diz, como fazia o Código anterior, que o seguro é um contrato entre duas partes para uma receber o prêmio e a outra ser

\footnotetext{
79 “Art. 685. Toda e qualquer coisa, todo e qualquer interesse apreciável a dinheiro, que tenha sido posto ou deva pôr-se a risco de mar, pode ser objeto de seguro marítimo, não havendo proibição em contrário."

80 "Art. 757. Pelo contrato de seguro, o segurador se obriga, mediante o pagamento do prêmio, a garantir interesse legítimo do segurado, relativo a pessoa ou a coisa, contra riscos predeterminados.”
} 
indenizada em caso de sinistro. Diz que o seguro é o contrato pelo qual a seguradora "se obriga, mediante o pagamento do prêmio, a garantir interesse legítimo do segurado, relativo a pessoa ou a coisa, contra riscos predeterminados". Assim, o objeto imediato ou causa do seguro passa a ser a garantia. ${ }^{81}$

O crédito da seguradora não mais corresponde a "um prêmio" qualquer. A norma usa o artigo masculino para assegurar a determinação desse crédito, diz "o prêmio": o prêmio que corresponde à garantia. Não mais se obriga a seguradora, além disso, a indenizar do prejuízo a contraparte. Ela se obriga a garantir o "interesse legítimo do segurado", havendo, pois, não só o esclarecimento de que a garantia é núcleo do contrato, mas também de que a identificação do credor da garantia se dá pela investigação da titularidade do interesse garantido.

Mesmo com essa substancial alteração no direito positivo, do art. 1.432 do Código Civil de 1916 para o art. 757 do Código Civil de 2002, e apesar da exuberância do fenômeno da despersonalização das relações obrigacionais ${ }^{82}$, ainda assim, o que transcende, indisputavelmente, no debate doutrinário sobre seguros, a percepção de um contrato bilateral paritário típico, é somente o caso da estipulação em favor de terceiro, quando aquele que estipula o contrato com a seguradora manifesta o desejo de proteger o interesse de outrem, na hipótese de suceder o evento contra cujos efeitos se pretendeu garantir com a contratação (beneficiário do capital segurado ou da indenização) ou durante a execução dessa obrigação de garantia (segurado $)^{83}$.

A compreensão da despersonalização das obrigações implica o reconhecimento de que o seguro destina-se a proteger interesses relativos aos bens da vida, e não estes bens em si, e que essa função deve ser tomada 'como 'bem' ou 'valor patrimonial', elemento constitutivo do patrimônio". 84

Os bens podem pertencer a uma pessoa, e interessarem a outra. A relevância de se reconhecer que o objeto da garantia do seguro é o interesse, despersonalizando-se a relação, é evidente quando visualizamos os grupos empresariais que movimentam de forma dinâmica seus interesses seguráveis, por meio de fusões, aquisições, criação de subsidiárias

\footnotetext{
${ }^{81}$ TZIRULNIK, Ernesto. O contrato de seguro - de acordo com o novo Código Civil brasileiro. $2^{\text {a }}$ ed. São Paulo: Revista dos Tribunais, 2003, p. 30.

${ }^{82}$ MARTINS-COSTA, Judith. Prefácio da obra de Gustavo HAICAL. Cessão de Crédito - Existência, Validade e Eficácia, São Paulo: Saraiva, 2013, p. 9.

${ }^{83} \mathrm{Faz}$ voga no setor de seguros dizer tomador ao invés de estipulante, usar a palavra estipulante como sinônimo de mandatário para a contratação de seguros coletivos e compreender aquele em favor do qual se contrata ora como segurado, ora como mero beneficiário. O beneficiário na verdade é, nos seguros em favor de terceiro, o legítimo titular do interesse garantido pelo contrato.

${ }^{84}$ MARTINS-COSTA, Judith. Prefácio da obra Cessão de Crédito..., cit., p. 10.
} 
e de sociedades de propósitos específicos. Como salienta Arnoldo Wald, empresas formam uma mesma unidade econômica quando, ainda que independentes, concorrem em conjunto para a consecução de um fim único, sem prejuízo do perseguimento de objetivos próprios por parte de cada uma delas. Assim, são características dessa estrutura empresarial a direção unificada e a presença de interesse grupal distinto do objetivo específico de cada sociedade. $^{85}$

Também Judith MARTINS-COSTA, em parecer inédito:

O dinamismo ínsito a essa ação a essa ação dirigida a criar bens econômicos não compactua com a rigidez das formas. Muito comumente uma mesma e única atividade empresarial é exercida por mais de uma pessoa jurídica, coordenadamente, em um grupo, de fato ou de direito. No grupo empresarial, há articulação dinâmica entre as várias pessoas que o compõem. Por razões da mais variada ordem (organizacional, tributária, estratégica etc), a atividade formalmente cometida a A passa a ser desempenhada, no todo ou em parte, por B. Como bem definiu ASCARELLI (Tullio Ascarelli. Corso di diritto commerciale: introduzione e teoria dell'impresa. $3^{\text {a }}$ Ed. Milano: Giuffré, 1962, p. 147160) na sua também muito conhecida e pioneira análise da atividade empresarial: sujeito da atividade empresarial é o sujeito dos atos dos quais resultam a mesma atividade

(...)

$\mathrm{O}$ fato bem evidencia o dinamismo ínsito à atividade empresarial acima lembrado. E nenhuma surpresa causou às oras Rés a assunção, pela Namisa, de parte das atividades de exportação de minério: como atestam o Relatório COPPETEC e correspondências da Sul América e do IRB (Instituto de Resseguros do Brasil) solicitando documentos da Namisa, durante o procedimento de regulação, o fato de ser a Namisa, subsidiária, co-titular do interesse segurado nunca foi objetado, sendo, ao revés, pacificamente aceito. ${ }^{86}$

A qualidade de parte, no direito contratual clássico, era sujeita a limites estreitos em razão da afirmação extremada da relatividade dos contratos. Como registram Glenda Gonçalves GONDIM, Pendro Henrique Gallitti KENICKE e Thais Braga BERTASSONI,

A regra geral dos efeitos do contrato é que sejam relativos às partes, por isso a nomenclatura do princípio que intitula o presente tópico do trabalho: "princípio da relatividade dos contratos". O aludido princípio tem como conceituação exatamente que, em determinado contrato, "seus efeitos se produzem exclusivamente entre as partes, não aproveitando nem prejudicando terceiros". No direito contratual, o vocábulo "parte" é utilizado para definir aqueles que participam do contrato, ou seja, que pactuaram entre si direitos e obrigações de acordo com seus interesse, por isso a contemporânea conceituação de partes como centro de interesses;

\footnotetext{
${ }^{85}$ WALD, Arnoldo. "Caracterização do grupo econômico de fato e suas consequências quanto à remuneração dos dirigentes de suas diversas sociedades componentes". In: Revista de Direito Bancário e do Mercado de Capitais, vol. 25, São Paulo: RT, 2004, p. 147-148.

${ }^{86}$ Parecer inédito intitulado Sinistro complexo - Extensão do seguro à Namisa - inocorrência de prescrição. Porto Alegre, de 12 de fevereiro de 2013, mimeo, p. 27-29.
} 
por sua vez, "terceiro" é adotado para definir aquele, estranho à relação contratual. Assim, entende-se como "parte" aquele que participou e declarou a sua vontade no negócio jurídico, sendo "terceiro", aquele que "cuja vontade, pelo contrário, é um elemento estranho à formação do contrato em causa" e para quem, não existem efeitos obrigacionais.

Como efeito, em razão da ausência de declaração de vontade desse denominado como "terceiro", sendo o objeto da relação direitos obrigacionais, não seria possível lhe impor " $a$ ) o conhecimento $d a$ existência ou do conteúdo de um contrato entre duas outras pessoas; b) a atuação positiva ou negativa em face desse contrato, exceto respeitar a produção regular de seus efeitos, desde que não invadam abusivamente sua própria esfera jurídica ". Portanto, a premissa é que, a partir deste princípio, as obrigações contratuais não podem estabelecer obrigações ou direitos para terceiros.

O professor Azevedo, em parecer pioneiro proferido no ano de 1998 e que permanece atual, apresenta uma (re)leitura da relatividade dos efeitos do contrato, ante os princípios previstos na Constituição Federal de 1988. $\mathrm{Na}$ visão do autor, a relação contratual, necessariamente, deve ser analisada diante do interesse as sociedade e, consequentemente, os princípios contratuais também devem ser analisados a partir da ideia solidarista, consolidada no ordenamento jurídico pela Carta Magna de $1988 .^{87}$

Hoje, o conceito encontra flexibilizado em virtude da melhor apreensão de realidades complexas pela experiência jurídica e pela virada ideológica a que deu impulso o Código Civil de 2002, fazendo penetrar a socialidade nos poros da teoria contratual e fundindo a função social do contrato com a autonomia privada, não como embalagem, mas como conteúdo. Nenhuma deficiência de compreensão ou redação de uma apólice de seguro pode, no entanto, sobrepor-se à dinâmica realidade da transubjetividade típica a que se encontram sujeitos os interesses seguráveis. Apenas a título ilustrativo, veja-se a amplitude do conceito de segurado numa apólice de responsabilidade civil estipulada pela Petróleo Brasileiro S.A. - Petrobras com a Allianz Seguros S.A.:

\section{Allianz (III) \\ Modernização da Refinaria de Paulínia Anexo a Apólice 03.67.0007140}

\begin{tabular}{|lcll|}
\hline \multicolumn{2}{|l|}{ Segurado } & & \\
PETRÓLEO BRASILEIRO S/A - PETROBRAS & & \\
Ramo & Vigência & & Apólice \\
$\mathbf{5 1}$-Responsabilidade Civil & $\mathbf{2 3 / 0 3 / 2 0 1 1}$ & à & $\mathbf{0 3 . 5 1 . 7 1 4 0}$ \\
& $\mathbf{2 1 / 0 6 / 2 0 1 3}$ & & \\
\hline
\end{tabular}

87 “A causa, os planos do negócio jurídico e a função social: análise a partir da teoria do terceiro cúmplice." In TEPEDINO, Gustavo e FACHIN, Luiz Edson (org). Pensamento crítico do direito civil brasileiro. Curitiba: Juruá, 2011, p. 62-63. 
Seção II - Responsabilidade Civil Geral

\begin{tabular}{|l|l|}
\hline \multicolumn{1}{|c|}{ 1. Segurado } & \multicolumn{1}{c|}{ CNPJ } \\
\hline PETRÓLEO BRASILEIRO S/A - & $33.000 .167 / 0001-01$ \\
PETROBRAS & \\
\hline - Todas as empresas subsidiárias, afiliadas, associadas, controladas, \\
companhias aliadas ou relacionadas, corporações, sociedades de propósito \\
específico, empresas ou organizações já constituídas ou que poderão ser \\
constituídas; \\
- Sócios em Joint Venture que possuem interesses financeiros e/ou seguráveis \\
nas propriedades a serem declaradas; \\
- Acionistas, diretores executivos, sócios e empregados das Empresas acima \\
ou que já tenham trabalhado em uma das empresas, enquanto atuando em \\
suas capacidades como tal. \\
- Executivos de projetos \\
- Qualquer outra Pessoa Física ou Jurídica, incluindo sem limitação, todos os \\
Contratados e Sub-Contratados e/ou Fornecedores, Consultores e qualquer \\
outro terceiro conforme exigido por aqueles com os quais o(s) segurado(s) \\
acima relacionados firmam um ou mais acordos e/ou contratos para cada \\
projeto. \\
- Financiadores
\end{tabular}

Dessa forma, a cobertura de algumas sociedades integrantes do mesmo grupo, excluindo-se outras, a despeito destas participarem diretamente da atividade segurada, vai de encontro à propria finalidade do contrato de seguro, que é a garantia do interesse associado a atividade econômica desempenhada em conjunto e orientada para um objetivo comum. Mesmo porque esse objetivo comum somente se concretiza por meio da atuação de todas as sociedades integrantes do grupo. ${ }^{88}$

Em geral, a percepção corrente sobre os contratos de seguro a que nos referimos, de tradição individualista e liberal, também ignora o fato de que, muitas vezes, tais contratos são formados compulsoriamente, por imposição de uma norma legal ou administrativa, por exemplo, ou como cumprimentos de condição ou adimplemento de outros contratos, ou ainda por constituirem prática de boa governança cuja não adoção

${ }^{88}$ TEPEDINO, Gustavo. "Opinião doutrinária” inédita mimeo, de 23 de novembro de 2012, Rio de Janeiro, p. 21. 
pode prejudicar ou impedir o exercício de uma atividade ou o seu exercício de forma útil ou mais proveitosa. ${ }^{89}$

A demonstrar que, apesar da virada plasmada no art. 757 do Código Civil, ainda causa grande polêmica a questão atinente à eficácia do contrato de seguro para além daqueles que, aparentemente, sejam suas únicas partes, é interessante ver a discussão a respeito da posição contratual das vítimas nos seguros de responsabilidade civil. $^{90}$

${ }^{89}$ As atividades econômicas e empresariais demandam boas estruturas financeiras não apenas para o seu financiamento, como para a sua proteção. O seguro é fundamental para essas duas exigências. Tomam-se recursos no mercado ou admitem-se como suficientemente protegidas as gestões de companhias abertas, facilitando-lhes persistir em bolsa, a existência e a continuidade dos seus seguros patrimoniais, operacionais e de responsabilidade. Tratando dos seguros obrigatórios, Francisco Serqueira, Jorge Paredes, Hernan Quiróz e Nicolás Canales, da secção chilena da Associação Internacional de Direito do Seguro, lembram que "[e]ssa verdadeira barreira de 'entrada' ao desenvolvimento de alguma atividade econômica pode originar-se na existência de uma norma legal que assim o exija ou bem nos usos e costumes que os diversos atores de mercados particulares adotem." "Seguros Obligatórios". In Anais do XII Congresso Iberolatinoamericano de Derecho de Seguros - II Congreso Internacional del Seguro - Assunción 27-29 de abril de 2011, Assunção: Seção Paraguaia da AIDA - Associação Internacional de Direito do Seguro, p. 91.

${ }^{90}$ MELLO FRANCO, Vera Helena de: "Nos seguros de responsabilidade civil, ao lado do interesse das partes, coloca-se o interesse da vítima prejudicada pelo ato danoso do segurado. O terceiro, embora estranho ao contrato, tem um interesse legítimo em obter a reparação do dano. Mas a vítima é a terceira perante o contrato celebrado entre segurado e seguradora e, assim, dele não poderia se valer para pleitear a indenização. No direito anterior, o Código Civil de 1916 não previa a possibilidade, que agora advém expressamente nos seguros de responsabilidade civil obrigatório (art. 788, parágrafo único, do CC/2002). Resta em aberto a questão com relaçãoao seguro de responsabilidade civil facultativo. Neste caso, a norma do $\S 3^{\circ}$ do art. 787 do CC/2002, afasta a hipótese, tendo em vista que contempla a ação do prejudicado contra o segurado. Volta-se, assim, à discussão de se admitir ou não a ação do terceiro prejudicado diretamente contra a seguradora. Dentre os que propugnam pela admissibilidade da ação direta em benefício da vítima ou de seus herdeiros, a questão situa-se no fundamento da ação. As sugestções variam. Para uns, a ação deveria ser reconduzida ao contrato, aguindo-se, como fundamento, a estipulação em favor de terceiros, a delegação imperfeita ou a cessão de crédito. Para outros, a possibilidade deveria decorrer da própria lei. Ambas as teses apresentam incovenientes. Os que fazem derivar do contrato, encontram obstáculos no fato do terceiro ser estranho ao contrato. Os que as querem fazer derivando de disposição expressa de texto legal, deparam-se com o fato de que, ressalva feita ao seguro obrigatório, raríssimas legislações preveem a possibilidade no seguro facultativo de responsabilidade civil. Sobre o ponto, vale a pena mencionar a posição de Ernesto Tzirulnik ( $O$ contrato de seguro de acordo com o novo código civil brasileiro, p. 139), a enfatizar que, se a seguradora responsável que se antepõe ao segurado, quando se cuida de prestar indenização (já que este só deverá fazê-lo quando a seguradora for insolvente, ex vi o disposto na norma do $\$ 4^{\circ}$ do art. 788 do CC/2002), não se justifica se negue ao prejudicado o direito à ação direta. De qualquer forma, esta não é, ainda, a orientação do direito vigente". MELLO FRANCO, Vera Helena de. Contratos: direito civil e empresarial. $2^{\mathrm{a}}$ ed. São Paulo, Editora dos Tribunais, 2011, p. 327-328. Ver também nesse sentido: FARIA, Juliana Cordeiro de. Seguro facultativo de responsabilidade civil: a problemática do direito de ação da vítima contra a seguradora na perspectiva do Código Civil de 2002. Tese de doutoramento apresentada à Faculdade de Direito da Universidade Federal de Minas Gerais em 2004, sob orientação do Professor Doutor Humberto Theodoro Júnior. A existência de pretensão própria da vítima contra a seguradora no seguro de responsabilidade civil celebrado pelo responsável, ainda que a jurisprudência a admita sempre que este também for demandado, é evidência da eficácia do contrato de seguro para além daqueles que, aparentemente, sejam suas únicas partes. Sobre o tema é indispensável o exame da tese Ação direta do terceiro prejudicado no seguro de responsabilidade civil: uma técnica processual a serviço do direito material, de Gustavo de Medeiros MELO. Tese de doutoramento apresentada à Faculdade de Direito da Pontifícia Universidade Católica de São Paulo em 2013, sob orientação do Professor Doutor Nelson Nery Jr. Ver também o Enunciado 544, aprovado por unanimidade nas Comissões de Contratos, de Responsabilidade Civil e Plenário da VI Jornada de Direito Civil (Conselho da Justiça Federal, março de 2013): "O seguro de responsabilidade civil facultativo garante dois interesses, o do segurado contra os efeitos patrimoniais da 
Também se reage a reconhecer que o conteúdo do contrato de seguro de grandes riscos não é livremente estabelecido entre os que participam da contratação, e que, portanto, se trata, também, de contrato por adesão decorrente da sua própria natureza. ${ }^{91}$ Igualmente, não se costuma dar atenção para o fato de que o conhecimento do real conteúdo do seguro - apesar de sua vigência ser costumeiramente ânua, muitas vezes com tratos sucessivos - não é conspícuo e, em regra, só será pesquisado pelos interessados quando e se acontecerem fatos que despertem pretensões pecuniárias.

Também pouco acontece de se perceber que terceiros reputados estranhos, como resseguradores e retro-resseguradores, determinam fundamentalmente o texto dos contratos de seguro, especialmente naqueles contratos de grandes riscos que servem para a proteção do desenvolvimento de obras de infraestrutura, indispensáveis para o desenvolvimento econômico e social de países como o Brasil. A liberdade de disposição das partes é ainda mais constringida, pois o conteúdo se atém a predisposições oriundas desses terceiros que contratam apenas com as seguradoras, em uma relação que constitui, portanto, res inter alios. Como adverte Agamenon MAGALHÃES, “[o] resseguro tornou-se a forma moderna e normal, prevista ou implicita nas clausulas contractuaes de seguro, deixando de ser o recurso do segurador contra o vulto do risco assumido, ou defesa do mercado de riscos aggravados". 92

Mesmo nos seguros mais facilmente identificados como de relevante interesse social, como o seguro obrigatório da infortunística do tráfego de veículos, a ideia de socialidade não implica, tout court, a compreensão de que terceiros possam ser considerados parte do contrato, informando o conteúdo, integrando o vínculo e aproveitando a sua eficácia:

imputação de responsabilidade e o da vítima à indenização, ambos destinatários da garantia, com pretensão própria e independente contra a seguradora.”

${ }^{91}$ Os contratos de adesão não são necessariamente contratos celebrados entre consumidores economicamente hipossuficientes e empresas fornecedoras de produtos e serviços. Embora entendamos que grandes empresas também podem ser consideradas consumidoras, aderindo à chamada definição maximalista de consumidor, quando se fala de contrato de seguro a questão não está vinculada à caracterização de relação de consumo. Os seguros em geral dependem de um regime de padronização de cláusulas que rechaça diversificação de conteúdo em razão da vontade das suas partes. A diluição ou atomização do risco deflagra estrutura atuarial que impõe a necessidade de conteúdos fixos e rígidos para os instrumentos contratuais. $\mathrm{O}$ tipo contrato de adesão, ensina Orlando GOMES, "abrange todos os casos de pré-constituição de cláusulas uniformes que devem ser insertas no conteúdo do contrato, sejam estabelecidas por um dos contraentes ou por outrem" (Contratos. Rio de Janeiro: Forense, 2009, p. 130). Arnoldo WALD ressalta que essa adesão se caracteriza pelo fato de que "um dos contratantes ou ambos não têm a liberdade contratual para discutir os termos do contrato, podendo apenas aceitá-lo ou recusá-lo, atendendo-se à própria natureza do contrato ou a determinações legais, que fixam as condições dos contratos de certo tipo." (Obrigações e contratos. São Paulo: RT, 1994, p. 183-184).

92 Op. cit., p. 45. 
O interesse aqui é coletivo. O seguro de responsabilidade civil obrigatório foi criado com evidente cunho social, ditado pela necessidade de tutelar as consequências dos atos danosos, derivados do exercício de determinadas atividades.

O interesse tutelado, no seguro obrigatório, é a incolumidade dos atos danosos para a terceira vítima que é a beneficiária indireta do contrato. Com este teor, o seguro aproxima-se da estipulação em favor de terceiros. Esta, além da obrigatoriedade, a diferença perante o seguro de responsabilidade civil facultativo, no qual o interesse é aquele do próprio segurado, com vistas a sua incolumidade patrimonial. ${ }^{93}$

Se é assim com os seguros obrigatórios, com os seguros de responsabilidade civil facultativos é agravada a dificuldade de atar o terceiro prejudicado ao contrato como parte. Embora o art. 787 do Código Civil brasileiro tenha expressado que "[n]o seguro de responsabilidade civil, o segurador garante o pagamento de perdas e danos devidos pelo segurado a terceiro", fixando aí que o seguro garante o interesse do terceiro com relação $a o$ seu crédito, a exemplo do que ocorre com a fiança em face do credor, os juristas em geral resistem em atribuir, a partir dessa regra, a qualidade de parte ao terceiro prejudicado. Muitos autores, mesmo os que mais profunda e criticamente examinam as pretensões e legitimidades entrosadas no seguro facultativo de responsabilidade civil, como Gustavo de Medeiros MELO $^{94}$, não chegam a divisar, aí, a existência de um seguro de crédito em favor do terceiro que se determina a partir do sinistro.

A relutância, a nosso ver, ocorre porque a dogmática jurídica trabalha à sombra da concepção liberal de contrato.Nessa concepção, a autonomia da vontade é utilizada para enfatizar o mito da liberdade individual e considera o contrato como manifestação dessa vontade, cuja substância e cujos efeitos devem ajustar-se à vontade real. ${ }^{95}$

\footnotetext{
${ }^{93}$ MELLO FRANCO, Vera de. Contratos, cit., p. 325. Na verdade aqui não se trata propriamente de seguro de responsabilidade civil. O legislador havia elaborado a regra do art. 788 do Código Civil de 2002 nos anos 1960, quando vigorava o regime do seguro RECOVAT (responsabilidade civil dos proprietários de veículos automotores de vias terrestres), criado nos termos do art. 20 do Decreto-lei $\mathrm{n}^{\mathrm{o}} 73$, de 21 de novembro de 1966, o qual veio a ser extinto e substituído pelo seguro DPVAT (danos pessoais causados por veículos automotores de vias terrestres), nos termos da Lei ${ }^{\circ}$ 6.194. de 19 de dezembro de 1974. A regra do art. 788, portanto, fora elaborada pelos autores do projeto que, em 2002, veio a se transformar em lei instituindo o Código Civil Brasileiro, tendo-se em conta os problemas atinentes ao acionamento das seguradoras do seguro RECOVAT e, logicamente, caso o DPVAT fosse oportunamente percebido pelos autores do Código como um seguro de dano, e não de responsabilidade, a regra do art. 788 teria outro teor, provavelmente especificando-se para incidir sobre os seguros obrigatórios em geral, ou especificamente ao DPVAT, e não sobre os seguros obrigatórios de responsabilidade civil.

${ }^{94}$ MELO, Gustavo de Medeiros. Ação direta do terceiro prejudicado no seguro de responsabilidade civil: uma técnica processual a serviço do direito material. Op. cit.

${ }^{95}$ LUCARELLI, Francesco; CIOCIA, Maria Antonia. Interessi privati e diritti soggettivi pubblici. Padova: CEDAM, 1997, p. 10. "Difatti la concezione che il liberalismo mutua dalle dottrine del diritto naturale esalta nell'autonomia privata il mito della libertà individuale e considera il contratto come manifestazione di volontà individuale, la cui sostanza ed il cui effetto deve esser commisurato alla volontà reale." ["Realmente, a concessão que o liberalismo empresta das doutrinas do direito natural enfatiza na autonomia privada o mito
} 
Exatamente por considerar o contrato como a manifestação da livre e real vontade dos que o celebram, a ideologia que se especifica no sistema jurídico liberal persegue - e consegue - evitar a intromissão de terceiros. Nesse sistema, a autonomia é amparada pelo chamado princípio da relatividade dos contratos, segundo a qual o pacto tem seus efeitos apenas entre as partes. Como diz o jurista italiano Enzo ROPPO, "a relatividade do efeito contratual é, com toda evidência, projeção do princípio do acordo, que por sua vez descende do valor da autonomia." 96

$\mathrm{O}$ art. 1.372 do Código civil italiano, por exemplo, estabelece que "[o] contrato não produz efeitos em relação aos terceiros". ROPPO adverte que o princípio da relatividade deve ser contido por limites justos, para entendê-lo nos justos significados: ele tem um alcance muito menos amplo do que poderia sugerir uma leitura superficial do referido artigo mas, de qualquer modo, esse confinamento do princípio jamais cede perante o "terceiro distante"; cede ante o "terceiro vizinho", mas não suplanta a condição de um regime de exceção de incidência do princípio da relatividade. ${ }^{97}$

Nosso sistema não dispõe de uma regra como a do art. 1.372 do Código Civil italiano, o que contribui para abrandar o dogma da relatividade. Conta, ao contrário, com instrumental contundente para a transformação da cultura obrigacional, que é a regra do art. 421 do Código Civil, segundo a qual "[a] liberdade de contratar será exercida em razão e nos limites da função social do contrato." 98

\subsection{Perspectivas jurídicas sobre a função social do contrato}

Diversos autores criticam a regra do art. 421. Luis Gustavo HADDAD, salienta que a função social do contrato é alegórica da "textura aberta da linguagem jurídica", e considera perigosa a locução "em razão" posta no art. 421 do Código Civil, "pois pode apontar para uma subordinação geral da liberdade contratual à consecução de determinados

\footnotetext{
da liberdade individual e considera o contrato como manifestação de vontade individual, cuja substância e cujo efeito deve ser adequado à vontade real."

${ }^{96}$ ROPPO, Vincenzo. "Il Contratto". Op. cit., p. 530.

${ }^{97}$ Idem, p. 530, tradução livre. Original: "Il principio di relatività va contenutto entro giusti confini, per intenderlo nei giusti significati: esso ha una portata molto meno ampia di quanto protebbe suggerire una lettura superficiale dell'art 1.372."

98 Além do art. 421 e do parágrafo único do art. 2.088, a função social também está amparada pelo parágrafo único do art. 2.035: "Nenhuma convenção prevalecerá se contrariar preceitos de ordem pública, tais como os estabelecidos por este Código para assegurar a função social da propriedade e dos contratos.".
} 
objetivos estabelecidos ou acolhidos pelo Estado". ${ }^{99}$ O autor rejeita a possibilidade de se encontrar na função social o instrumento para promover o interesse público:

Não pode ser atribuída aos agentes econômicos privados, por força da função social do contrato, o papel de funcionários encarregados de promover o interesse público. Há uma distância considerável, e que não pode ser ignorada, entre não ofender a ordem pública e promover o interesse público, sob pena de se comprometer o próprio sentido da autonomia privada. ${ }^{100}$

HADDAD, assim, conclui opinando pela inexistência de funções inerentes aos contratos, que devem orientar-se exclusivamente pela satisfação dos interesses individuais:

[i]nexistem verdadeiras e próprias funções no direito contratual; o terreno dos contratos é dominado pelo valor da autonomia privada, que se traduz em um agir autárquico, no interesse próprio; o exercício da autonomia privada, em outras palavras, não reclama qualquer justificativa externa que transcenda o puro e simples agir para si.

Apoiando-se no paradigma da eficiência adotado pela chamada Escola do Direito e Economia, Luciano Benetti TIMM defende um sistema jurídico apoiado em modelo regulatório no qual o direito admite que o mercado é fato e necessidade social, e o defende e robustece, permitindo seu desenvolvimento de modo a beneficiar toda coletividade que nele interage. Para o autor, reforçar um direito tipicamente privado gerará maior riqueza social, devendo a função social ser entendida como mera diretriz destinada a promover a liberdade do funcionamento do mercado. ${ }^{101}$ Em síntese, declara que "[a] função social do contrato, como roupagem jurídica de operações econômicas, não é a relativização do pacta sunt servanda, mas a instrumentalização das trocas, onde quem ganha é a coletividade". ${ }^{102}$

\footnotetext{
${ }^{99}$ Função social do contrato - um ensaio sobre seus usos e sentidos. São Paulo: Saraiva, 2013, p. 18-21. ${ }^{100}$ Idem, 198-199.

${ }^{101}$ TIMM, Luciano Benetti. O novo direito civil - ensaio sobre o mercado - a reprivatização do Direito Civil e a privatização do Direito Público. Porto Alegre: Livraria do Advogado, 2008, p. 90-91: “Ao contrário, ao gerar maior eficiência das instituições sociais de mercado, será um direito tipicamente privado que gerará maior riqueza social e, portanto, maiores condições para a própria redistribuição, em seu local adequado, via tributação e políticas públicas governamentais (que são inequivocamente o melhor instrumento para gerar 'justiça social'). Dito isso, e como o Direito cumpre aquela função social de operacionalização das relações de mercado?

Basicamente, se estiver comprometido com aquelas instituições jurídicas que instrumentalizam o seu funcionamento (do mercado): a livre iniciativa, a autonomia privada (o contrato) e a propriedade. Isso porque são esses institutos jurídicos que operam um verdadeiro 'acoplamento estrutural' entre o sistema jurídico e o sistema econômico. Nesse sentido, a função social da concorrência, do contrato e da propriedade está relacionada em um sistema econômico capitalista, à operabilidade do mercado. Com efeito, se o mercado joga importante papel na sociedade, quanto melhor o seu desempenho, maior a função social do direito." ${ }^{102}$ Idem, p. 92.
} 
Entretanto, é perceptível que a doutrina brasileira festeja o advento do art. 421, ainda que seja hegemônica ao manter a autonomia da vontade como base de sustentação do contrato. $^{103}$

A grande cautela prevalece entre os juristas que tratam do tema e os colocam em busca da "dialética de complementariedade" entre os fatores liberdade e a função social para lograr "uma relação permanente e progressiva que impede a compreensão de um sem o outro", como ocorre com Gerson Luiz Carlos BRANCO, que vê na função social "uma das dimensões do contrato", portanto seu "elemento constitutivo e não mero limite externo". 104

A perspectiva de Eros GRAU que é epígrafe deste capítulo também revela a função social como elemento que se integra ao conteúdo ("configuração interna") dos vínculos. Coincide ainda com as doutrinas Bueno de GODOY e de Judith MARTINS-COSTA, para quem "[o] princípio da função social, ora acolhido expressamente no Código Civil (arts. 421 e $1.228, \S 1^{\circ}$ ) constitui, em termos gerais, a expressão da socialidade no Direito Privado, projetando em seus corpora normativos e nas distintas disciplinas jurídicas a diretriz constitucional da solidariedade social (CF, art. $3^{\circ}$, II, in fine)." ${ }^{105}$

A ideia de socialidade, a rigor, ultrapassa a projeção da solidariedade social. A Constituição Federal brasileira encarta diversos outros princípios e objetivos, além da solidarização, que se integram para a formação do conteúdo da socialidade.

103 THEODORO JR., Humberto. O contrato e sua função social, $3^{\mathrm{a}}$ ed. Rio de Janeiro: Editora Forense, 2008: "A teoria geral do contrato, portanto, enriquece-se com três novos princípios, que não podem, todavia, ser encarados como, doravante, os únicos a dominar e explicar os fundamentos da figura jurídica da mais importante categoria dos negócios jurídicos. Na verdade, os três novos princípios - boa-fé objetiva, equilíbrio econômico e função social - não eliminaram aqueles em que a ideologia liberalista havia se fixado (liberdade de contratar, força obrigatória do contrato e eficácia relativa da convenção). O que se deu foi o acréscimo aos clássicos, de princípios forjados sob o impacto das atuais idéias de sociedade e solidarismo que a ordem constitucional valorizou" (p. IX). Não obstante entender que a base estruturante do contrato é a autonomia da vontade, THEODORO JR. esclarece que essa autonomia se identifica através de diferente perspectiva ideológica, a qual tem como fio condutor a socialidade, sendo vedada compreender liberdade ou autonomia "ignorando os interesses de terceiros e da coletividade": "Quando o Código Civil adota a linha da socialidade - e nela se insere a função social do contrato - não está colocando a sociedade em patamar superior ao indivíduo. Está cumprindo a programação constitucional que prevê, no relacionamento público ou privado, a implantação de um modus vivendi inspirado no valor da solidariedade social. O que esse programa combate não é a liberdade individual nem a autonomia da vontade. O que se visa é à regulação do exercício desses direitos fundamentais, de sorte que deixem de se inspirar no egoísmo individualista e se interpretem segundo o solidarismo. O contraste se estabelece não entre indivíduo e coletividade, mas entre individualismo e solidarismo. O indivíduo, na nova ordem da socialidade, não pode exercitar a liberdade contratual ignorando os interesses de terceiros e da coletividade. Nem os terceiros podem ignorar os direitos e interesses emergentes do contrato para seus figurantes. É assim que se há de compreender o valor ético-jurídico perseguido pelo instinto da função social do contrato, no contexto do Código Civil e da Constituição." (op. cit, p. 137-138).

${ }^{104}$ BRANCO, Gerson Luiz Carlos. Função Social dos Contratos: interpretação à luz do Código Civil. Sâo Paulo: Saraiva, 2009, p. 305-306.

${ }^{105}$ MARTINS-COSTA, Judith. Reflexões sobre o princípio da função social dos contratos. Op. Cit., p. 41. 
É o caso da busca de uma sociedade livre e justa (CF, art. $3^{\circ}$, I), das projeções principiológicas da dignidade da pessoa humana (art. $1^{\circ}$, II e 170 caput), do valor social do trabalho e da livre iniciativa (art. $1^{\circ}$, IV e 170, caput), o buscar a garantia do desenvolvimento nacional (art. $3^{\circ}$, II) e da liberdade de associação profissional ou sindical (art. $8^{\circ}$ ), perseguir a erradicação da pobreza e da marginalização social, assim como a redução das desigualdades regionais e sociais (art. $3^{\circ}$, III e 170, VII), buscando-se permanentemente a justiça social na ordem econômica (art. 170), a soberania nacional, a proteção da propriedade e de sua função social, da livre concorrência, da defesa do consumidor, do meio ambiente, enveredando, ainda, na busca do pleno emprego e do favorecimento das empresas brasileiras de capital nacional de pequeno porte (art. 170, IX), assim como do fortalecimento do mercado interno, como patrimônio nacional, a ser incentivado de modo a viabilizar o desenvolvimento cultural e socioeconômico, o bem estar da população e a nossa autonomia tecnológica (art. 219).

É para garantir a penetração na vida dos negócios de todo esse quadro de desideratos constitucionais que adquire relevo a doutrina de Cláudio Luiz Bueno de GODOY, no sentido de que

(...) a função social do contrato não pode ser entendida, na perspectiva de um sistema jurídico voltado à promoção de valores constitucionais fundamentais básicos, simplesmente como um instrumento limitativo, de feição negativa, no caso, do direito de contratar. Trata-se, também, de o contrato funcionalizado, servir à promoção daqueles valores, das escolhas do sistema. ${ }^{106}$

Dada a amplitude do conjunto de princípios e objetivos fixados na constituição econômica ${ }^{107}$, e da sua potencial contradição prática ${ }^{108}$, após dizer que o princípio da função social é uma expressão da "diretriz da socialidade", indicando "um rumo a seguir, oposto ao individualismo predatório", MARTINS-COSTA emenda a seguinte conjunção

${ }^{106}$ GODOY, Claudio Luiz Bueno de. Função social do contrato, $3^{\text {a }}$ ed. São Paulo: Saraiva, 2009, p. 196.

107 "Nesta mesma linha, podemos adotar algumas das premissas expostas por Washington Peluso Albino de Souza, principalmente a de entender, assim como Irti e vários outros, a Constituição Econômica como parte integrante, não autônoma ou estanque, da Constituição total. Na sua visão, as Constituições Econômicas caracterizar-se-iam pela presença do econômico no texto constitucional, integrado na ideologia constitucional. E seria a partir dessa presença do ecônomico no texto constitucional e da ideologia constitucionalmente adotada que se elaboraria a política econômica do Estado". BERCOVICI, Gilberto. Constituição Econômica e Desenvolvimento: uma leitura a partir da Constituição de 1988, op.cit., p.13.

${ }^{108}$ Como adverte José Maria Arruda de Andrade, por ausência de "vontade política e sem uma consideração teórica que leve a sério os aspectos textuais, sistemáticos e teleológicos da Constituição, só nos restará torcer para que a ponderação de princípios como o da pretensa subsidiariedade do Estado e o da dignidade da pessoa humana da iniciativa privada tragam algo além da negação do próprio Estado e da desvalorização do trabalho humano." "Hermenêutica da ordem econômica constitucional e o aspecto constitutivo da concretização constitucional". In Revista Fórum de Direito Financeiro e Econômico. Ano 1, $\mathrm{n}^{\mathrm{o}} 1$, (março/agosto - 2012) Belo Horizonte: Ed. Fórum, 2012, p. 265. 
adversativa: "também é certo que a expressão se estende sobre um território tão vasto quanto acidentado.",109

É oportuna a advertência de MARTINS-COSTA sobre a amplidão e a rugosidade do caminho necessário para a apreensão do significado da função social das relações obrigacionais. Assim, se o direito "deve ser exercido em consonância com as suas finalidades econômicas e sociais" (Código Civil, art. 1.228, $\S 1^{\circ}$ ) e se a liberdade de contratar deve "ser exercida em razão e nos limites da função social do contrato" (Código Civil, art. 421), o estudo dos negócios jurídicos é remetido para o bojo das reflexões sobre os princípios e os objetivos que a sociedade traçou para si própria na Constituição Federal.

Referindo-se aos escritos que alardeavam a inconstitucionalidade do Projeto do Código ${ }^{110}$ e o acusavam de "retrógrado e demagógico", Gustavo TEPEDINO celebra o fato de que

\begin{abstract}
[a]bandona-se, deliberadamente, o discurso hostil dos que, justamente, entreviam a incompatibilidade axiológica entre o texto codificado e a ordem pública constitucional. Afinal, o momento é de construção interpretativa e é preciso retirar do elemento normativo todas as suas potencialidades, compatibilizando-o, a todo custo, à Constituição da República. Esta louvável mudança de prospectiva, que se alastra no espírito dos civilistas, não há de ser confundida, contudo, com uma postura passiva e servil à nova ordem codificada. Ao revés, parece indispensável manter-se um comportamento atento e permanentemente crítico em face do Código Civil para que, procurando lhe conferir a máxima eficácia social, não se percam de vista os valores consagrados no ordenamento civil-constitucional. ${ }^{111}$
\end{abstract}

TEPEDINO entende que as cláusulas gerais do (na época) novo Código Civil não são normas prescritivas, mas definidoras de parâmetros e valores hermenêuticos. Para o autor, as normas servem como ponto de referência interpretativo, como critério e limite para a aplicação das demais disposições. Para além disso, têm o poder de representar relevante alteração no panorama do direito privado brasileiro se forem aplicadas segundo a lógica da solidariedade constitucional. ${ }^{112}$

\footnotetext{
${ }^{109}$ MARTINS-COSTA, Judith. Reflexões sobre o princípio da função social dos contratos. Op. cit., p. 41-42. ${ }^{110}$ Luiz Edson FACHIN e Carlos Eduardo PIANOVSKY RUZYK. "Um Projeto de Código Civil na Contramão da Constituição". Revista Trimestral de Direito Civil, 2000, vol. 4. Rio de Janeiro: Ed. Padma, 2000. p. 243 e ss.

111 TEPEDINO, Gustavo. Crise das fontes normativas e técnica legislativa na parte geral do Código Civil de 2002. In: TEPEDINO, Gustavo (coord.). A parte geral do novo Código Civil: Estudos na perspectiva civilconstitucional. $3^{\text {a }}$ ed. revista, Rio de Janeiro: Renovar, 2007. p. XV e ss.

112 Idem, p. XXI. O autor prossegue: "À luz do texto constitucional, a função social torna-se razão determinante e elemento limitador da liberdade de contratar, na medida em que esta só se justifica na persecução dos fundamentos e objetivos da República", definindo-se a "função social" "como o dever imposto aos contratantes de atender - ao lado dos próprios interesses individuais perseguidos pelo
} 
Para o autor, assim, a tarefa dos juristas constitui um "desafio metodológico" para a leitura do Código "na perspectiva civil-constitucional", com o objetivo de atribuir a todo o Código, inclusive às cláusulas gerais, "um significado coerente com a tábua de valores do ordenamento, que pretende transformar efetivamente a realidade a partir das relações jurídicas privadas, segundo os ditames da solidariedade e justiça social". ${ }^{113}$

Embora se possa discutir se realmente é possível transformar a realidade com uma tábua de valores do ordenamento jurídico moldante das relações jurídicas privadas, a função social - essa "cláusula geral", esse "valor consagrado", "ponto de referência interpretativo", "critério axiológico", "razão determinante e elemento limitador da liberdade de contratar" ou "dever de atender interesses extracontratuais" - é uma poderosa ferramenta que o direito civil positivado brasileiro oferece para o jurista atuar politicamente.

A questão é saber se a função social do contrato projeta interesses extracontratuais socialmente relevantes, dignos de tutela jurídica, que se relacionam com o contrato, ou se, ao contrário, diz respeito a interesses propriamente contratuais diretamente contribuintes para o conteúdo e submetidos à eficácia do negócio jurídico. Quer-se identificar em favor de quem o contrato de seguro deve existir, ter conteúdo, ser interpretado e executado.

Cláudia Lima MARQUES, a propósito do tema, sustenta que, para a nova concepção social de contrato, não só o momento o momento da manifestação da vontade importa, mas onde também e principalmente os efeitos desse contrato para a sociedade. Segundo a jurista, não se quer dizer que conceitos tradicionais, tais como os de negócio jurídico ou autonomia da vontade, desaparecerão, mas apenas que "o espaço reservado para que os particulares autorregulem suas relações será reduzido por normas imperativas". Dá-se, no seu entender, "uma nova concepção de contrato no Estado Social, em que a vontade perde a condição de elemento nuclear, surgindo em seu lugar elemento estranho às partes, mas básico para a sociedade como um todo: o interesse social."114

É provável que a função social realmente viabilize a utilização do direito contratual como elemento de intervenção da comunidade, não propriamente do Estado, nas relações obrigacionais. Se isto não acontecer, assistiremos a mais um capítulo da demagogia com que a dogmática jurídica disfarça as marcas do envelhecimento e da subserviência.

regulamento contratual - a interesses extracontratuais socialmente relevantes, dignos de tutela jurídica, que se relacionam com o contrato ou são por ele atingidos", p. XXXII.

113 Op. cit., p. XXXIII.

${ }^{114}$ MARQUES, Cláudia Lima. Contratos no Código de Defesa do Consumidor: o novo regime das relações contratuais. $6^{\text {a }}$ ed. São Paulo, Revista dos Tribunais, 2011, p. 210-211. 
O problema é que o significado de "função social" pode variar pelas mais diversas razões, e deve ser buscado na concretude a verdade da locução, uma pesquisa, diga-se assim, lacaniana, para quem um significante se forma antes dos seus significados: "Digo sempre a verdade: não toda, porque dizê-la toda não se consegue. Dizê-la toda é impossível, materialmente: faltam as palavras. É justamente por esse impossível que a verdade provém do real." 115

A "arbitrariedade" e a "instabilidade" dos significados nos textos escritos é fenômeno conhecido, causadora de "colisão" no campo da filosofia e da crítica literária até mesmo entre sociedades material e culturalmente equivalentes, como é o caso dos anglosaxões e europeus, e como lembra Stephan COLLINI,

[a] tentativa de limitar o âmbito de contextos relevantes na atribuição de sentido ou de fixar as instabilidades interminavelmente autodissolventes da escrita foi estigmatizada como "autoritária"- acusação que é por si só um exemplo da prontidão com que as questões teóricas complexas têm sido ligadas a atitudes políticas mais amplas. ${ }^{116}$

O ordenamento jurídico, embora tenda a ser instrumento através do qual os interesses são acomodados por comandos cogentes sob o amparo do Estado, legitimando a dominação, constitui-se, como as obras literárias, de "ícones verbais" plenos de "tensões" e "ambigüidades", de sorte que os mecanismos semióticos do direito sempre estão sujeitos a serem operados de forma que os significados se ajustem aos diversos contextos. Quando se reclama da concreção ou aplicação da norma jurídica em flagrante contrariedade à aparente significação que o seu texto apresenta, muitas vezes se está reclamando do ajustamento que se faz com o objetivo de que a solução normativa não viole, ao menos tão flagrantemente, o contexto sujeito à sua incidência.

O encontrar um significado para a locução "função social" é realmente um problema que precisa ser resolvido para que a socialidade intervenha, segundo o método admitido à dogmática jurídica, pois, de um lado, “um significante considerado isoladamente não possui nenhum significado" ${ }^{117} \mathrm{e}$, de outro, pretender que a função social

115 LACAN, J. Televisão. Rio de Janeiro: Jorge Zahar, 2003, p. 11

116 COLLINI, Stephan. Introdução: interpretação terminável e interminável in ECO, Umberto. Interpretação e superinterpretação, $3^{a}$ ed., p. 8. São Paulo: Editora WMF Martins-Fontes, 2012.

${ }^{117}$ Sobre esta visão de LACAN ver o interessante trabalho de Paulo SILVEIRA: "É neste preciso sentido que a dimensão simbólica em Lacan pode ser considerada como uma cadeia (ou bateria) de significantes. Então, nessa precedência do significante sobre o significado, um significante considerado isoladamente não possui nenhum significado. Ele apenas pode produzir significado na relação com outro ou com outros significantes. Sucede, portanto, com o significante, o mesmo que com uma mercadoria, que não pode expressar seu valor em si mesma. Assim, uma relação entre significantes, que, portanto, produz, significação, é exatamente 
signifique um feliz encontro das partes consigo mesmas e com os outros, não é utopia, é supina alienação.

Roland BARTHES, no seu Elementos de semiologia, chama a importância das estruturas e dos sistemas para a formação dos significados, ressaltando que "a língua é o domínio das articulações e o sentido é recorte, antes de tudo", seguindo-se que a busca da semiologia deverá ser "muito menos estabelecer léxicos de objetos do que reencontrar as articulações a que os homens submetem o real". ${ }^{118}$

Encontrar o significado da a função social, portanto, depende dos juristas e de suas intenções.

A partir da noção de estrutura como um "todo de significações", MARTINSCOSTA identifica as duas ideias-chave que se encontram no art. 421 (liberdade de contratar e função social), duas diferentes acepções para função social: a função como limite da liberdade de contratar e como fundamento da sua existência. ${ }^{119}$

A partir daí, compreendida a liberdade e os possíveis diferentes aspectos em que se pode buscar o significado da função social em relação à liberdade de contratar, a autora observa que a dificuldade para interpretação da expressão ou do sintagma, na realidade, remanesce no adjetivo social. O problema é colocado do seguinte modo pela autora:

dizendo respeito a um direito subjetivo (a liberdade de contratar), o "social" - que adjetiva a "função" - pode ser conotado ou à expansão intersubjetiva da liberdade, ou à expansão transubjetiva da liberdade. ${ }^{120}$

A expansão intersubjetiva diz respeito aos limites que conformam o âmbito de garantia do direito subjetivo, isto é, o direito com seus limites ontológicos. A expansão transubjetiva pressupõe limites que vêm, do exterior, para comprimir o direito, o qual teoricamente poderia ser ilimitado.

homóloga à relação de valor entre as mercadorias. (...).” (Lacan e Marx: a ideologia em pessoa in Crítica Marxista, $\mathrm{n}^{\circ}$ 14, p. 121. São Paulo: Boitempo, 2002)

${ }^{118}$ BARTHES, Roland. Elementos de semiologia. São Paulo: Cultrix, 2012, p. 171.

${ }^{119}$ Como o primeiro princípio mencionado no art. 421 é o da liberdade de contratar, a autora se propõe a identificar se esse princípio poderia ser visto independentemente, se ele seria mera decorrência da autonomia da vontade ou se "teria ligação estrutural e funcional" com a função social mencionada na norma. Observa que, no seu entender, a liberdade a que se refere o princípio deve ser entendida como uma "liberdade situada, a liberdade que se exerce na vida comunitária"119. Nessa perspectiva conclui "[d]aí a imediata referência logo após a liberdade de contratar à função social do contrato; (...) liberdade e função social se acham entretecidos, gerando uma nova ideia, a de autonomia privada solidária". Diferenciando a autonomia privada, que se forma a partir da "liberdade situada", a autora a distingue da "autonomia da vontade", observando que esta constitui uma construção ideológica, que foca o contrato exclusivamente pelo perfil subjetivo, além de corresponder à" tradução jurídica de uma forma econômica própria do capitalismo comercial oitocentista, ainda não dominado pela grande empresa e pela produção em massa, aceitando-se, então, a ideia de uma quase que 'espontânea' composição dos interesses econômicos interprivados." (Op. cit. p. 43-44)

${ }^{120}$ MARTINS-COSTA, op cit., p. 47. 
Embora se possa identificar a relevância da função social como limite externo da conformação do conteúdo dos vínculos contratuais, pois significa a imposição de deveres negativos - limites - para as partes, para além dos previstos em lei, se o princípio da função social do contrato se restringisse ao papel de limite externo, o art. 421 seria provavelmente inútil, pois na opinião da jurista a experiência jurisprudencial mostra que a regra do art. 187, do Código Civil, ou a regra do art. 423, somado a previsões de leis especiais, ao Código de Defesa do Consumidor ou ao Estatuto de Terra, já bastariam para proteger a quase totalidade dos interesses. ${ }^{121}$

Assim, é necessário encontrar voz específica para o art. 421. No entender de MARTINS-COSTA, essa voz se encontraria no que denomina por "segundo nível de compreensão semântica" da função social contida no artigo. Ou seja, a função social como razão de ser do exercício da liberdade de contratar, e não como limite dessa liberdade:

\begin{abstract}
A expressão "em razão da" função social indica, concomitantemente: a) que a função social do contrato integra, constitutivamente, o modo de exercício do direito subjetivo, (liberdade contratual); b) que é o seu fundamento, assim reconhecendo-se que toda e qualquer relação contratual possui, em graus diversos, duas distintas dimensões: uma intersubjetiva, relacionando as partes entre si; outra, transubjetiva, fazendo reverberar as obrigações e os direitos assumidos pelos contratantes na esfera de terceiros, determinados ou indeterminados. Assim, a função social não opera apenas como um limite externo, é também um elemento integrativo do campo de função da autonomia privada no domínio da liberdade contratual. ${ }^{122}$
\end{abstract}

Reconhece-se no contrato, portanto, a sua capacidade de fazer reverberar as obrigações e os direitos assumidos pelos contratantes na esfera de terceiros. Identifica-se, assim, uma eficácia positiva na relação intersubjetiva, que é exemplificada pela autora através de três grupos de casos: o dos "contratos que instrumentalizam os bens de produção", como os societários, onde, por exemplo, já se decidiu que a dissolução de uma sociedade anônima não pode prescindir do exame das razões "que militam em prol da preservação da empresa e da cessação de sua função social, tendo em vista que os interesses sociais hão de prevalecer sobre os de natureza pessoal de alguns dos acionistas", os contratos que viabilizam prestações essenciais, como é o caso dos seguros de vida, seguro saúde, fornecimento de água e energia elétrica, transporte pessoal, importação de medicamentos relevantes, e os chamados contratos comunitários, que seriam um "novo item da taxinomia contratual", aqueles que estão submetidos à noção de comunidade por

\footnotetext{
${ }^{121}$ MARTINS-COSTA, op. cit., p. 49-50.

122 Idem ibidem.
} 
sua própria racionalidade econômico social - "como os de seguro" - "uma vez que, num dos pólos, não está meramente o interesse de uma soma aritmética de 'individualidades', mas interesses supra-individuais ou coletivos." 123

Observa ainda que a transindividualidade ou comunitariedade formam a essência jurídica e econômica desses contratos, de forma que não podem ser afastadas sob pena de desvirtuamento de sua causa, ou função econômica e social:

Uma coletividade não é formada pela mera soma de individualidades, já tendo percebido a filosofia grega que o todo não é apenas a mera soma das partes: no todo, há um plus que se agrega, e este é o interesse comum, inconfundível com cada interesse isoladamente considerado. É justamente a existência do interesse comum a todos os particulares membros que conduz à ideia de comunidade, razão pela qual na apreciação desses contratos os direitos subjetivos de cada um dos contratantes não podem ser vistos de modo atomístico, como se cada um fosse uma entidade isolada, envolvido na hobbesiana luta de todos contra todos. Desta compreensão resulta a afirmação da transindividualidade ou comunitariedade que está no fulcro da operação jurídica e econômica de tais contratos. No contrato de fornecimento de energia elétrica, por exemplo, assim como seria inadequado pensar numa conformação de conteúdos diferentes para cada contrato, igualmente não se poderia cogitar da diversidade da proporção de contribuições (preços, tarifas, prêmios, contraprestações) a cargo de cada um dos contratantes, utentes do benefício ou serviço instrumentalizado pelo contrato. É que, nesses casos, a ideia de uma comunitariedade ou transindividualidade dos interesses em causa não pode ser afastada sob pena de ser desvirtuada a sua própria causa, ou função econômico-social. Essas concepções restam reforçadas se tivermos presente que tais contratos estão assentados na solidariedade social, valor afastado pelo individualismo, mas que hoje retorna ao cerne dos ordenamentos jurídicos contemporâneos por expresso reconhecimento constitucional e legal. ${ }^{124}$

Conclui, assim, que é a produção de eficácias transubjetivas que consubstancia a função mais própria da locução "em razão da" e que mais potencializa inovações no campo do direito contratual pois, quer dizer que o contrato já é concebido como uma relação jurídica que não interessa só às partes contratantes e que não é impermeável às condições sociais que o cercam. ${ }^{125}$

É essa dimensão social que permite alterar-se a visão estrita que o direito liberal propiciou para o exame e tratamento dos contratos, sob a armadura da relatividade, especialmente quanto à apreensão de quem são suas partes, como observam GONDIM, KENICKE e BERTASSONI:

123 Decisão do STJ citada por MARTINS-COSTA, op. cit., 51-52.

${ }^{124}$ MARTINS-COSTA, op. cit., p. 53-54.

${ }^{125}$ Idem ibidem. 
A regra geral dos efeitos do contrato é que sejam relativos às partes, por isso a nomenclatura do princípio que intitula o presente tópico do trabalho: "princípio da relatividade dos contratos". O aludido princípio tem como conceituação exatamente que, em determinado contrato, "seus efeitos se produzem exclusivamente entre as partes, não aproveitando nem prejudicando terceiros". No direito contratual, o vocábulo "parte" é utilizado para definir aqueles que participam do contrato, ou seja, que pactuaram entre si direitos e obrigações de acordo com seus interesse, por isso a contemporânea conceituação de partes como centro de interesses; por sua vez, "terceiro" é adotado para definir aquele, estranho à relação contratual. Assim, entende-se como "parte" aquele que participou e declarou a sua vontade no negócio jurídico, sendo "terceiro", aquele que "cuja vontade, pelo contrário, é um elemento estranho à formação do contrato em causa" e para quem, não existem efeitos obrigacionais.

Como efeito, em razão da ausência de declaração de vontade desse denominado como "terceiro", sendo o objeto da relação direitos obrigacionais, não seria possível the impor " $a$ ) o conhecimento da existência ou do conteúdo de um contrato entre duas outras pessoas; $b$ ) a atuação positiva ou negativa em face desse contrato, exceto respeitar a produção regular de seus efeitos, desde que não invadam abusivamente sua própria esfera jurídica ". Portanto, a premissa é que, a partir deste princípio, as obrigações contratuais não podem estabelecer obrigações ou direitos para terceiros.

O professor Azevedo, em parecer pioneiro proferido no ano de 1998 e que permanece atual, apresenta uma (re)leitura da relatividade dos efeitos do contrato, ante os princípios previstos na Constituição Federal de 1988. $\mathrm{Na}$ visão do autor, a relação contratual, necessariamente, deve ser analisada diante do interesse as sociedade e, consequentemente, os princípios contratuais também devem ser analisados a partir da ideia solidarista, consolidada no ordenamento jurídico pela Carta Magna de 1988. ${ }^{126}$

Cláudio Luiz Bueno de GODOY, como já vimos, rejeita o entendimento de que a função social somente produz efeito limitativo sobre a vontade dos que celebram o negócio jurídico. Ele também entende que a função social integra o conteúdo do contrato para promover os valores constitucionais, devendo os contratantes exercerem sua liberdade em consonância com as "escolhas e valores do sistema", atuando de forma não apenas a promover seus interesses, mas a promovê-los de modo a especificar na realidade os cometimentos axiológicos do ordenamento jurídico. ${ }^{127}$ Conclui, assim, o jurista:

$\mathrm{O}$ que se tem, enfim, é a função social do contrato integrando-lhe o conteúdo, garantindo que o ato de vontade receba tutela jurídica, desde que seja socialmente útil e sirva à promoção de valores constitucionais fundamentais - portanto uma função não só negativa e limitativa -, dentre os quais a dignidade humana, de que, é certo, o exercício da liberdade contratual não deixa de ser uma expressão, como visto. Ou seja, a vontade não fica excluída do processo formador do contrato, não deixa de

\footnotetext{
${ }^{126}$ Op. cit., p. 62-63.

${ }^{127}$ Op. cit., p. 196.
} 
ser o móvel criador do negócio, mas cujo efeito normativo encontra sua origem na incidência do ordenamento, condicionada à verificação da consonância do ato de iniciativa da parte às escolhas e valores do sistema. De resto, mais, como uma forma de prestigiá-los e fomentá-los.

Portanto, não se entrevê no dispositivo do art. 421 nada mais senão a expressão da releitura que o ordenamento impôs ao instituto do contrato ou, antes, da própria autonomia privada, tal como ao longo deste trabalho se procurou demonstrar. A dicção legal ostenta-se coerente com o que hoje se entende, ainda de forma atual, por autonomia privada. E representa um instrumento de garantia e prestígio a valores constitucionais que precisam ainda ser implementados na prática das relações negociais, especialmente aquelas intrinsecamente desequilibradas, em modelo que, nessa medida, e para essas relações, não se considera superado porque nem mesmo completamente assimilado. ${ }^{128}$

A concepção segundo a qual a função social, à parte o alarmismo radical que permite a alguns temerem a revolução das estruturas pela ação jurídica oriunda da própia sociedade, é "instrumento de garantia e prestígio a valores constitucionais que precisam ainda ser implementados na prática das relações negociais" é essencial para o desenvolvimento da nossa sociedade, pois permite a mais genuína reflexão e crítica e consequente produção de cultura realmente democrática, já o sistema do direito privado negocial positivado é concebido segundo os interesses da classe dominante. ${ }^{129}$

\subsection{Perspectivas econômicas sobre a função social do contrato}

Pairam fundadas dúvidas sobre a possibilidade de realização de um projeto que tenha o bem estar da coletividade como fruto do incentivo à livre atuação do mercado

\footnotetext{
128 Idem ibidem.

${ }^{129}$ LOPES NETO, Silvino. Perspectivas do Direito e Seus Valores no $3^{\text {o }}$ Milênio in Perspectivas do Direito no Início do Século XXI, Coimbra: Coimbra Editora, Boletim da Faculdade de Direito, Stvdia ivridica, $\mathrm{n}^{\circ} 42$, colloquia 3, 1999, p. 23-25. "Por aí se pode observar o trabalho importante e insubstituível do sistema jurídico na sociedade. É o direito quem revela a autoconsciência normativa do grupo humano obrigado, porque as opções valorativas que devem servir de norte aos grupos sociais, estão postas nas normas jurídicas. Aqui defrontamos outro grande problema na construção do direito. Trata-se da criação do direito e das forças que influenciam, até determinam, sua génese. Todos os que são iniciados em ciência jurídica percebem que o direito costuma ser o resultado das aspirações da classe dominante. Esta é que tem a capacidade de influir sobre os corpos legislativos para deles extrair as normas jurídicas de sua conveniência. No futuro tal questão será certamente agudizada. E mais: a classe dominante, sobretudo as megacorporações mercantis, manipulam, por seu poder econômico, inclusive como anunciantes, os meios de comunicação. A mídia eletrônica tem todo o interesse em colocar-se a serviço do grande capitalismo e condiciona o que se conhece como opinião pública. Que, aliás, não passa de opinião publicada, como salientava Winston Churchill. Grassa pelo mundo, com sucesso, a ideia de que se deve diminuir o Estado. Sua intervenção na vida societária conviria restringir-se ao essencial. Tudo que escape às missões escritas e insubstituivelmente estatais, interessa ficar entregue à direção privada. Ganha mais espaço a concepção privatística como solução para as crises do Estado atual. A proposta é chegar-se ao Estado mínimo. (...) Um Estado forte, por rico, poderia ajudar de forma considerável. Quem substituirá o Estado? A alta finança transnacional? Claro que não. Essa não tem qualquer compromisso com o social. Apenas o lucro sensibiliza os megaempresários. Não terão nenhuma disposição em sustentar quem não esteja a seu serviço. O que não será novidade, nem motivo para espanto, pois sempre tem sido assim”.
} 
"autorregulado", e inclusive se pode identificar acentuado verniz ideológico nesse discurso.

Colocando em xeque a posição de Luciano Benetti TIMM segundo a qual "se o mercado joga importante papel na sociedade, quanto melhor o seu desempenho, maior a função social do direito" "130, Eric Hobsbawm lembra as experiências sociais concretas dos anos 1970 e 1980, de fracasso das políticas sociais neoliberais:

Quem, a não ser a autoridade pública, iria e poderia assegurar um mínimo de renda e bem-estar social para todos? Quem poderia contrabalançar as tendências à desigualdade tão impressionantemente visíveis nas Décadas de Crise? A julgar pela experiência das décadas de 1970 e 1980, não seria o livre mercado. Se essas décadas provaram alguma coisa, foi que o grande problema político do mundo, e certamente mundo desenvolvido, não era como multiplicar a riqueza das nações, mas como distribuí-la em benefício de seus habitantes. Isso se dava mesmo em países pobres "em desenvolvimento" que precisavam de mais crescimento econômico. O Brasil, um monumento à negligência social, tinha um PNB per capita quase duas vezes maior que o Sri Lanka em 1939, e mais de seis vezes maior no fim da década de 1980. No Sri Lanka, que subsidiara alimentos básicos e dera educação e assistência médica gratuitas até a década de 1970, o recém-nascido médio podia esperar viver vários anos mais que o brasileiro médio, e morrer ainda bebê mais ou menos na metade da taxa brasileira de 1969, e num terço da taxa brasileira de 1989 (World Tables, 1991, p. 144-7, 524-7). A percentagem de analfabetismo em 1989 era quase duas vezes maior no Brasil que na ilha asiática. ${ }^{131}$

A ideia de que o mercado opera naturalmente (autoregulação) o bem estar social também é criticada por Marco Aurelio GARCIA, sob o aspecto geopolítico:

Mas, da mesma forma que havia um "socialismo real", distinto daquele que a hagiografia "marxista-leninista" proclamava e celebrava, há um capitalismo, "realmente existente", que não coincide com a utopia da sociedade autorregulada e "pós-industrial". A colossal expansão das forças produtivas, a inovação tecnológica e a revolução comercial em curso - deixando de lado os avatares, admitamos conjunturais, da crise se dá, no entanto, circunscrita geograficamente.

Uma pequena parte do mundo (20\%) é responsável por cerca de $80 \%$ da produção, circulação e consumo de bens e serviços, enquanto $80 \%$ da humanidade produz e usufrui $20 \%$ da riqueza criada mundialmente.

O impacto desta realidade sobre os fenômenos de pauperização aguda que se registram no mundo com todas suas implicações sociais, inclusive aqui no Brasil, não necessita ser sublinhado. ${ }^{132}$

\footnotetext{
${ }^{130}$ Op. cit., p. 90-91.

131 HOBSBAWM, Eric. Era dos extremos: O breve século XX - 1914-1991. 2a ed. Tradução de Marcos Santarrita. São Paulo: Companhia das Letras, 1995.

132 GARCIA, Marco Aurélio. "Uma história sem fim”. In: Tempo e História. NOVAES, Adauto (org.). São Paulo: Companhia das Letras, 1992, $3^{\text {a }}$ reimp., 2006, p. 96.
} 
Cuidando da soberania econômica na Constituição de 1988, a partir do caso do petróleo e dos recursos minerais, Gilberto BERCOVICI ilustra a utilização da doutrina liberal como ameaça às conquistas obtidas:

\begin{abstract}
Apesar das conquistas obtidas, a soberania permanente sobre os recursos naturais como princípio do direito econômico internacional vem sendo contestada desde os anos 1970, com a retomada da preponderância do pensamento econômico neoclássico, a adoção das políticas neoliberais de privatização e ajuste fiscal ortodoxo, bem como a tentativa de imposição de uma nova lex mercatoria como substituta da pretendida Nova Ordem Econômica Internacional. ${ }^{133}$
\end{abstract}

A perspectiva do eficientismo adotada pelos autores que vêem no enriquecimento do mercado a premissa bastante do desenvolvimento social e econômico, acaba por convergir, embora tenha outro matiz ideológico, com a instalada no Código italiano de 1942. Referindo-se à ideologia fascista, Francesco LUCARELLI e Maria Antonia CIOCIA observam que ela, além de atuar como enérgica garantidora do regime capitalista - ao promover o ideal de solidariedade, no sentido de que cada indivíduo contribui para o interesse geral da produção econômica, produzindo a "sujeição das consciências ao nacionalismo", com isso eliminando os conflitos trabalhistas -, permitiu identificar a eficiência econômica do direito como sua função social:

Além disso, o desenho garantista reforça as estruturas de direito subjetivo, racionalizando suas funções por meio de técnicas inspiradas nos juízos de valor. A perspectiva não é percebida pela doutrina, desviada, nos limites da credibilidade, da equivoca referência à "função social" da propriedade e às regras de "solidariedade" previstas no exercício da autonomia privada. Percorrendo o código vigente percebese, no entanto, como a propriedade continua sendo representada (art. 832) na relação direta, imediata e exclusiva entre o titular e o bem; e como a função "social" marca somente juízos de valor destinados a garantir a melhor utilização (atos de interferências).

$\mathrm{Na}$ ideologia fascista a função da propriedade perde toda justificação naturalista. É representada como extensão da personalidade individual. Nela funda-se o ordenamento familiar e a transmissibilidade hereditária que confirmam a natureza de célula indispensável ao tecido social. Encontra-se na Exposição de Motivos do código civil (n. 403) que "a ordem corporativa respeita o princípio da propriedade privada. Esta completa a personalidade humana; é um direito, e se é um direito, é também um dever. De modo que nós pensamos que a propriedade privada deve ser compreendida como função social: portanto, não a propriedade passiva, mas a propriedade ativa, que não se limita a gozar os frutos da riqueza, mas os desenvolve, os aumenta e os multiplica". Nesta estrutura eficientista, ao desaparecimento do abuso corresponde a expansão do direito do proprietário na disciplina dos atos de interferências, que

${ }^{133}$ BERCOVICI, Gilberto. Direito Econômico do Petróleo e dos Recursos Minerais. São Paulo: Quartier Latin, 2011, p. 197. 
garantem a projeção para fora do poder subjetivo, justificada pelo interesse "socialmente" relevante à utilização pessoal do bem. Também a autonomia privada modifica somente sua função instrumental, sobrepondo à ideia de negócio, expressão de vontade, o contrato como "centro de vida empresarial". Nisso é evidenciada, na estrutura do ato, a organização de interesses, com implícito juízo de responsabilidade sobre as capacidades de operador econômico do sujeito, o que exalta o jogo individual dos interesses até o limite do ilícito e da lucratividade tolerada (a rescisão negocial).

Desta forma, o código de 42 realiza a reavaliação da "função" do direito subjetivo, pois não persegue unicamente o fim de garantir o poder real ou mediado do sujeito sobre o bem, mas sim introduz critérios de utilização em conformidade com o interesse prevalente dos titulares. A operação ocorre por meio da estratégia dos juízos de valor, que permite ao ordenamento, reconhecida à propriedade e autonomia privada função criativa de interesses, operar estímulos constantes à atividade individual. Ponto de conexão é o princípio de solidariedade ao sistema, aos "interesses gerais da produção", que responsabiliza o sujeito em relação à "ordem objetiva das coisas". ${ }^{134}$

Não há dúvida de que a concepção de socialidade, assim como a leitura do ordenamento constitucional e o exercício da ponderação entre os princípios e os objetivos da República, além de sujeitos a conteúdo diacrônico, refletem posições políticas e filosóficas, flexionando para a proteção dos interesses da classe dominante, como observam MARX e ENGELS em A Ideologia Alemã, ao apontarem o movimento empreendido pela burguesia para transformar seu ideário particular em ideias e ideais universais. $^{135}$

${ }^{134}$ Op. cit., p. 14-15. A propósito da eficiência econômica protegida pela doutrina italiana identificada com o autoritarismo fascista, é interessante também observar a advertência por Sérgio Sérvulo da CUNHA:

Logo, se houver uma justiça econômica, ou uma ética na economia, ela consistirá, para alguns, exatamente na obediência a essa lei natural e às respectivas formas de equilíbrio. Reza esse cânon que odo o agente econômico deve buscar a realização da maior vantagem possível e assim fazendo estará concorrendo para o bem geral, na medida em que a harmonização dos díspares interesses concorrentes se opera mediante a atuação de uma espécie de mão invisível, que preside aos mercados. Opera-se desse modo uma inversão quanto ao que, normalmente, se entende como o comportamento moral: os agentes econômicos ficam liberados para buscar a maior vantagem possível para si mesmos, independentemente do prejuízo que venham a sofrer os demais. (CUNHA, Sérgio Sérvulo da. Uma deusa chamada Justiça. São Paulo: Martins Fontes, 2009, p. 116-117).

Por outro lado, não são poucos, os juristas que refugam validar a importância da função social para o desenvolvimento das instituições jurídicas, identificando na sua abertura semântica, e não no eficientismo do mercado, o viés totalitário, como se posiciona Raquel SZTAJN em um dos mais veementes agravos à regra do art. 421: "Normas jurídicas de expresso viés ideológico ou político-ideológico e regimes democráticos capitalistas combinam mal; elas atendem melhor aos interesses do Poder nos regimes ditatoriais, em que o governo, confundido com o Estado, crê saber melhor que qualquer cidadão o que convém a todos e a cada um".

135 MARX, Karl e ENGELS, Friedrich. A ideologia Alemã. Org. e trad. Marcelo Backes. Rio de Janeiro: Civilização Brasileira, 2007, p. 72 e ss. "Se, na concepção do processo histórico, as ideias da classe dominante são separadas desta mesma classe, se as transforma em algo à parte e independente, se nos limitamos a afirmar que em uma época dominou este ou aquele pensamento, sem nos preocuparmos o mínimo que seja com as condições de produção nem com os produtores dessas ideias, se, portanto, deixamos de lado os indivíduos e as situações universais que servem de base aos pensamentos, podemos afirmar, por 
As relações negociais podem, ou não, ser condutas positivas para o desenvolvimento do conjunto da sociedade em que são travadas ou para a qual se dirigem. Adam SMITH, reconhecendo que os interesses engrenam os negócios dizia, já no século XVIII, que a vida negocial tornou-se "a mais fértil fonte de divergência e animosidade", e propõe, supondo grande facilidade, "impedir" os fornecedores de serviços e produtos de "perturbar a tranquilidade de qualquer um, exceto a deles mesmos", desfazendo-se, assim, a confusão entre o "bom senso da humanidade" e os interesses dos que dominam o comércio e a indústria, pois "o interesse deles é, com relação a isso, diretamente oposto ao da grande maioria do povo." 136

É certo que a ordem jurídica tende não a solucionar os problemas sociais e econômicos, mas a promover a manutenção das relações de produção em prestígio aos interesses dominantes na sociedade. Isso, no entanto, não quer dizer que o Código Civil de 2002 - especialmente os artigos 421 e $1.228, \S 1^{\circ}$, instrumentados por outras normas, como o artigo 187, o qual condiciona com parcimônia (manifesto extravaso) o exercício dos direitos "aos limites impostos por seu fim econômico ou social" - não aproe o Direito para o desenvolvimento das condições necessárias para o bem estar coletivo.

A função social, a meu ver, é princípio que atua como poderoso instrumento de política jurídica, um princípio altercador que questiona valores centrais vigentes e instituídos no contexto ideológico do liberalismo, e que busca transformar a prática contratual em canal de incidência da ordem jurídica como um todo, especialmente a ordem jurídica constitucional. Desse modo, contribui para a contenção do desbragado

exemplo, que na época em que dominou a aristocracia imperaram as ideias da honra, da lealdade etc., enquanto que a dominação da burguesia representou o império das ideias da liberdade, da igualdade etc. (...) Via de regra, a própria classe dominante assim o imagina. Essa concepção da história, que prevalece entre todos os historiadores desde o século XVIII, obrigatoriamente se deparará com o fenômeno de que são cada vez mais abstratas as ideias que imperam, quer dizer, que se revestem cada vez mais da forma do universal. Cada nova classe que passa a ocupar o posto daquela que dominou antes dela se vê obrigada, para poder encaminhar os fins que persegue, a apresentar o seu próprio interesse como interesse geral de todos os membros da sociedade - quer dizer, expressando o mesmo em termos ideiais -, a imprimir às suas ideias a forma de universalidade, a apresentar essas ideias como as únicas racionais e válidas universalmente."

136 SMITH, Adam. A mão invisível. Tradução brasileira de Paulo Geiger, $1^{a}$ ed. São Paulo: Penguin, 2013, p. 98. A despeito da visão smithiana sobre o comércio, o economista escocês, cuidando da questão da busca pelo monopólio, enfatiza que não é a prática da cooperação que de fato está além do pano de fundo do comércio: "O comércio, que naturalmente deveria ser um fator de união e amizade entre as nações, assim como entre os indivíduos, tornou-se a mais fértil fonte de divergência e animosidade (...) Mas embora talvez não se possam corrigir a capacidade mesquina e o espírito monopolizador de comerciantes e manufatores, que não são e não deveriam ser os governantes da humanidade, eles podem facilmente ser impedidos de perturbar a tranquilidade de qualquer um, exceto a deles mesmos. (...) Em cada país, sempre é e deve ser do interesse da maioria do povo comprar o que quer que deseje daqueles que o vendem mais barato. Essa proposição é tão evidente que parece ridículo fazer qualquer esforço para prová-la; nem poderia jamais ter sido questionada, não tivesse a sofística interesseira de comerciantes e manufatores confundido o bom senso da humanidade. O interesse deles, é com relação a isso, diretamente oposto ao da grande maioria do povo." 
individualismo capitalista, fenômeno robustecido nos anos 1970 e que tende a colher a cumplicidade de todos nós, mesmo que despercebidamente. ${ }^{137}$

Como lembra Eros GRAU, “as soluções de que cogitamos somente poderão ser tidas como corretas quando e se adequadas e coerentes com a ideologia constitucionalmente adotada." 138

A função social, de tal modo, ao aderir o programa da sociedade, como um todo, às vontades individuais formadoras dos negócios, é elemento intrínseco a estas e deve ser examinado para sua compreensão ou interpretação, como para a avaliação de seus eventuais vícios.

Para avaliar a presença e o significado da função social não se olham os negócios em si, entre as partes do contrato que saltam aos olhos, mas na sua afeição ao meio social. Numa expressão, a função social é instrumento da sociedade para a implementação da política social e econômica do Estado.

Assume destarte a função social a qualidade de instrumento para a operatividade da socialidade e de todos os direitos fundamentais destinados a garanti-la, a partir dos negócios jurídicos, não podendo prescindirem os contratos de, assim, também incorporarem o objetivo desenvolvimentista, pois, como ressalta Paulo BONAVIDES, o desenvolvimento é "o mais importante direito fundamental da terceira geração."139

O conceito de desenvolvimento não se confunde com o aumento dos volumes absolutos da produção econômica. Ao se produzirem campeões de faturamento e lucratividade na indústria e no comércio, entesourarem-se bancos e seguradoras, colocarem-se megaempresários no topo das competições financeiras internacionais ou mesmo ao se elevar o produto interno do país, tudo isso significa que está havendo acumulação de capital, mas não singifica que haja desenvolvimento.

A ideia de desenvolvimento pressupõe para a sociedade um processo contínuo de mobilidade social e esse processo é acompanhado do aumento dos níveis econômico e

\footnotetext{
${ }^{137}$ Ver FARIA, José Eduardo. O Direito na economia globalizada. $1^{\text {a }}$ Ed. $2^{\text {a }}$ Tiragem. São Paulo, Malheiros, 2000, p. 112: "O Estado de Bem Estar Social ascende a partir dos anos 1930 e decai quatro décadas depois, nos anos 1970."

${ }^{138}$ GRAU, Eros. A ordem econômica na constituição de 1988, cit., p. 194.

${ }^{139}$ BONAVIDES, Paulo. Reflexões - Política e Direito, $3^{\text {a }}$ ed. rev. e ampl. São Paulo: Malheiros, p. 384. Segundo o autor, direitos de primeira geração são os direitos individuais da tradição liberal clássica; de segunda, são os direitos sociais, como o direito à educação, à saúde, ao trabalho, ao lazer, à segurança, à previdência social, à materindade e à infância, à assistência para os desamparados etc.; de terceira geração são o direito à paz, o direito ao desenvolvimento, o direito ao meio ambiente e o direito ao patrimônio comum ao gênero humano.
} 
cultural-intelectual da comunidade. Trata-se de uma mudança de ordem qualitativa também, não apenas quantitativa. ${ }^{140}$

Segundo Celso FURTADO, o desenvolvimento, diferentemente do crescimento, só pode ser alcançado com a intervenção do Estado, jamais com o mercado como protagonista: "[a] ação do Estado tem sido essencial para promoção do desenvolvimento. Este só se efetivou no Brasil como fruto de uma vontade política. Os mercados desempenharam sempre um papel coadjuvante." 141

Prossegue o ex-Ministro do Planejamento e da Cultura do Brasil relatando que se havia engajado, na segunda metade dos anos 1950, no Projeto Nacional de Desenvolvimento, momento histórico no qual “[e]ra fácil perceber que a reconstrução de um sistema econômico requeria técnicas complementares de coordenação de decisões com projeção no tempo e fora do alcance dos sistemas mercantis."

Essa foi a percepção que permitiu e informou a elaboração, pela Comissão Econômica para a América Latina (CEPAL) que FURTADO dirigia naquela época, de um Manual de Técnica de Planejamento que serviu de base para o Plano de Metas do governo Kubitschek, "o que permitiu ao Brasil avançar consideravelmente na industrialização."143

Após o comemorado desenvolvimento econômico, sobreveio em 1964 longevo regime autoritário que abafou a "resistência dos excluídos" permitindo agravar "as tendências perversas do nosso desenvolvimento mimético." O regime ditatorial favoreceu os interesses da área econômica, mas piorou o grau de isolamento político, determinando o desenvolvimento autárquico da esfera política na forma de poder tecnocrático. Dessa combinação deu-se no Brasil aquilo que FURTADO denomina por "fantasia geopolítica

\footnotetext{
${ }^{140}$ GRAU, Eros Roberto. A ordem econômica na constituição de 1988 (interpretação e crítica). São Paulo: Editora Revista dos Tribunais, 1990, p. 234. Também nesse sentido, Celso FURTADO: "Nós, economistas, tivemos certa responsabilidade nisso ao embalarmos o sonho do Enrichissez-vous, monsieur, como se dizia na França: 'Enriqueça e salvaremos o país', pois o coeficiente de poupança crescerá mais do que a renda individual e será possível acelerar o crescimento. Era o raciocínio simplório dos economistas de alguns anos atrás. Hoje o Brasil tem uma renda dez vezes maior do que tinha quando comecei a estudar esses problemas, mas tem também maiores desigualdades, e os pobres continuam igualmente pobres. Cabe a pergunta: Houve desenvolvimento? Não: o Brasil não se desenvolveu; modernizou-se. O desenvolvimento verdadeiro só existe quando a população em seu conjunto é beneficiada.” (p. 20-21). Segundo Furtado, somente após o ufanismo que envolveu a plateia do desenvolvimento da economia brasileira nos anos que seguiram é que se pode perceber que "as economias subdesenvolvidas podem conhecer fases prolongadas de crescimento de seu produto global e per capita, sem reduzir o grau de dependência externa e a heterogeneidade estrutural interna, que são suas características essenciais." (FURTADO, Celso. Em busca de novo modelo: reflexões, cit., p. 32).

${ }^{141}$ FURTADO, Celso. Em busca de novo modelo: reflexões sobre a crise contemporânea. São Paulo: Paz e Terra, 2002, p. 09.

${ }^{142}$ FURTADO, Celso. Op. cit., p. 29.

${ }^{143}$ FURTADO, Celso. Op. cit., p. 30.
} 
aberrante da "potência emergente", o que considera uma das raízes de endividamento externo do país que levou a descalabro nunca imaginado à economia brasileira. ${ }^{144}$

Nesse ponto FURTADO se refere à crise experimentada ao tempo em que escrevia, na passagem para os anos 2000. O economista, então, pergunta-se: “[c]omo se apresenta o nosso país após um longo período de crescimento industrial que se prolongou por quase meio século?" E responde: “acumulamos uma dívida externa descomunal, enfrentamos um endividamento interno do setor público que acarreta a desordem das finanças do Estado, enquanto mais de um terço da população sofre de carência alimentar". A conclusão obtida pelo economista é de que "o processo de globalização interrompeu o avanço na conquista de autonomia para se tomarem decisões estratégicas"145

BELLUZZO, num artigo intitulado Além da conjuntura relata o processo que terminou por excluir o Brasil do rol de países emergentes:

Desde meados dos anos 80 do século XX, a estrutura e a dinâmica da produção e do comércio globais foram transformadas pela concomitância entre os movimentos da grande empresa dos países centrais e as políticas nacionais dos emergentes, particularmente as da China. O Brasil, protagonista das décadas anteriores, ficou fora do jogo, golpeado pela crise da dívida externa dos anos 80 , depois paralisado pela política cambial e de abertura sem estratégia na posteridade da estabilização dos anos 90. Entorpecidos pelas trapaças ideológicas dos economistas comprometidos com a finança, o País não conseguiu acompanhar a reconfiguração espacial e tecnológica dos núcleos manufatureiros globais.

(...)

Desde meados dos anos 70 do século $\mathrm{XX}$ as transformações na morfologia da grande empresa transnacional deram origem a uma estruturação dos mercados e às formas contemporâneas de concorrência de escala global.

O movimento da grande empresa promoveu a reconfiguração do ambiente internacional.

(...)

No Brasil dos anos 50, 60 e 70 havia sinergia - como em qualquer outro país - entre o investimento público, então comandado pelas empresas estatais, e o investimento privado. ${ }^{146}$

Embora reconhecendo que a causa imediata da crise sentida nos anos 1990 residia no grave desequilíbrio da balança de pagamentos que fora causada por razões de origem interna e externa, FURTADO dá conta de que a crise sofrida pelo povo brasileiro não pode ser simplesmente atribuída aos movimentos operados na economia mundial sendo,

\footnotetext{
${ }^{144}$ FURTADO, Celso. Op. cit., p. 32-33.

${ }^{145}$ FURTADO, Celso. Op. cit., p. 34.

146 BELLUZZO, Luiz Gonzaga. "Além da conjuntura". Carta Capital. ano XVIII, no 761, 14 de agosto de 2013, página 38 .
} 
substancialmente, o resultado da tentativa de "reproduzir a cultura material do capitalismo mais avançado" 147 que acabou por produzir "a contrafação de uma sociedade de massas em que coexistem formas sofisticadas de consumo supérfluo e carências essenciais no mesmo extrato social, e até na mesma família."148

A conclusão que Celso FURTADO obtém, a partir dessa constatação, é de que é necessária "criatividade política impulsada pela vontade coletiva", impondo-se "formular a política de desenvolvimento com base numa explicitação dos fins substantivos que almejamos alcançar, e não com base na lógica dos meios imposta pelo processo de acumulação comandado pelas empresas transnacionais". É imperativo abandonarmos as montagens conceituais que não têm raízes em nossa história e concretude. A reflexão necessária implica, nas suas palavras, “contrastar a lógica dos fins, que rege a cultura, com a lógica dos meios, razão instrumental inerente à acumulação puramente econômica." 149

Revelando-se exímio cientista social, ou qualificado economista, Celso FURTADO constrói no opúsculo de 2002 uma excelente explicação a respeito do conceito de socialidade. A socialidade, bem o demonstra, exige a desmistificação do mercado, entronizado pelas nossas elites empresariais, tecnocratas, políticas e acadêmicas.

Parece certo que a crise do conhecimento e do ensino, notadamente o jurídico, reside na insegurança dos juristas causada pela contaminação ideológica do neoliberalismo financeiro, a cujos grandes protagonistas muitos servem e deles dependem, enquanto outros são simplesmente cooptados ideologicamente. É esclarecedor o raciocínio furtadiano:

Se admitirmos que nosso objetivo estratégico é conciliar uma taxa de crescimento econômico elevada com absorção do desemprego e desconcentração da renda, temos de reconhecer que a orientação dos investimentos não pode subordinar-se à racionalidade das empresas transnacionais. Devemos partir do conceito de rentabilidade social a fim de que sejam levados em conta os valores substantivos que exprimem os interesses da coletividade em seu conjunto. Somente uma sociedade numa economia desenvolvida, com elevado grau de homogeneidade social, pode confiar na racionalidade dos mercados para orientar seus investimentos estratégicos. Essa discrepância entre racionalidade dos mercados e interesse social tende a agravar-se com a globalização." ${ }^{150}$

O fato de o Brasil ter grande potencial de recursos naturais e gravíssimas divergências sociais o tornam bastante vulnerável e enfatizam a importância de se

\footnotetext{
${ }^{147}$ FURTADO, Celso. Op. cit., p. 35.

${ }^{148}$ FURTADO, Celso. Op. cit., p. 35-36.

${ }^{149}$ FURTADO, Celso. Op. cit., p. 37.

${ }^{150}$ FURTADO, Celso. Op. cit., p 40.
} 
desenvolver um "projeto nacional, recuperando para o mercado interno o centro dinâmico da economia" ${ }^{\prime 151}$, que é exatamente aquilo que está bastante bem plasmado na Constituição Federal brasileira cujo art. 219 estatui que "[o] mercado interno integra o patrimônio nacional e será incentivado de modo a viabilizar o desenvolvimento cultural e socioeconômico, o bem-estar da população e a autonomia tecnológica do país nos termos da Lei Federal."

A sonhada hegemonia política da classe trabalhadora "tende a cumprir-se perversamente em benefício de estruturas empresariais transnacionais":

A atuação da empresa de âmbito planetário constitui mutação maior na evolução do sistema capitalista, pois desloca para posição subalterna as forças sociais que estava em ascensão e modifica substancialmente o papel do Estado nacional. Nessa nova fase do quadro evolutivo, a criação tecnológica - principal fonte de poder - está orientada de preferência para as atividades ligadas à informática e às comunicações, visando reduzir distancias e aumentar eficácia das estruturas de dominação (...)

A transnacionalização das empresas, no quadro da globalização de segmentos crescentes das estruturas econômicas acarreta a atrofia das funções estatais o que exige reciclagem profunda das estruturas tradicionais de poder. ${ }^{152}$

A ideia de progresso do iluminismo, fundada sobre a liberdade e a autonomia da vontade dos homens já não mais se ajusta como bandeira apta a promover a formulação jurídica; ela é dado de um momento histórico completamente ultrapassado pelas forças do processo econômico.

Celso FURTADO, novamente mostrando a impossibilidade de se dissociar a criação jurídica do campo das relações sociais e da economia, enfatiza que a apreensão da socialidade no âmbito jurídico é um dos mais importantes motores da inventividade requerida para o desenvolvimento econômico e social:

A invenção de novos tipos de associação entre membros de uma sociedade e a institucionalização das relações (de cooperação ou conflitivas) entre indivíduos e grupos são a expressão da capacidade criadora do homem em uma das suas formas mais nobres. Assim, na evolução do capitalismo, a invenção da sociedade anônima - instituição por um grupo de pessoas privadas de uma entidade com personalidade autônoma e vida indefinida - constitui autêntica mutação. Ademais, a invenção da greve - essa instituição sui generis que possibilita o uso controlado da violência fora do Estado - não terá sido mutação de menor lance. (...)

Expressão superior da convivência política, a criação de novas formas sociais é certamente inseparável de um sistema de valores. Com efeito, a necessária legitimidade pressupõe a consciência de fins no pacto social.

${ }^{151}$ FURTADO, Celso. Op. cit.,p 42.

${ }^{152}$ FURTADO, Celso. Op. cit. p. 50-51. 
Não se ignora que na atividade política os aspectos operacionais podem ganhar considerável importância, dado que o avanço das técnicas de coleta e manipulação da informação produz necessariamente hipertrofia do poder burocrático. Contudo, na vida social nada é mais indicativo de canalização de forças criadoras para os fins do que a existência de atividade política. ${ }^{153}$

A compreensão a respeito da ideia de socialidade que deve preencher o significado da função social dos contratos não pode ficar à margem dessas reflexões. Vivemos em um país que não está à frente do processo econômico, que se encontra sujeito a continuar crescendo à custa de recursos não-renováveis e avassalando-se aos interesses daqueles países e conglomerados transnacionais que surfam a onda do progresso tecnológico, valendo-se da redução do alcance da ação reguladora dos Estados nacionais, compreendendo-se nessa expressão - ação reguladora - a própria formulação dos valores que devem animar e reger as trocas na sociedade e promover o desenvolvimento sem o qual estar na sociedade é não pensar por conta própria, ser dependente e viver entre a perplexidade e a alienação.

Tornar a liberdade e a socialidade coisas divergentes ou tão só distintas, menos ainda, fracionáveis, é como considerar a crítica e a poesia como manifestações literárias antagônicas, o que, sem dúvida, traz grande conforto para aquele que não se vê livre para participar da reformulação jurídica indispensável à transformação do país, com "imaginação e coragem para arriscar na busca do incerto."

Mais do que dominar a tecnologia jurídica em si, impõe-se a descoberta do significado dos institutos jurídicos a fim de que estes efetivamente possam cumprir a função de integrar a sociedade a cada átomo das manifestações produzidas no seu âmago, e para ela relevantes.

Sem dúvida que na postura daqueles que não se propõem a revirar a semântica conquistada ao longo da experiência liberal intensificada pela financeirização que se implantou ao mesmo tempo em que ruíram os Estados sociais, será mais fácil o lucro e haverá confortante alienação pois, como a propósito da antagonização entre a crítica e a poesia bem lembrou Sérgio Buarque de HOLANDA, “[é] um prazer para o espírito poder

\footnotetext{
${ }^{153}$ FURTADO, Celso. op. cit., p. 62-63.

${ }^{154}$ FURTADO, Celso. op. cit., p. 79.
} 
descansar nessas delimitações rígidas, sugestivas e lapidares que consente o abandono de toda inquirição mais profunda." 155

Há quase um século, os fenômenos da concentração e da globalização já haviam criado a desumana figura do conglomerado transnacional que não se torna um indivíduo, nem uma empresa que possa se esconder, com litros de verniz, por detrás da igualdade formal com o fim de justificar o discurso anacrônico sobre liberdade.

Mas, diz Pietro BARCELLONA, "[1]iberdade e comunidade já não se podem conjugar como conceitos antagônicos. A liberdade se converte na medida de um vínculo social livre e da determinação positiva de fins comuns". ${ }^{156}$ Enfim, pese a resistência ideológica em busca da volta ao laisser faire, laisser passer, essa tarefa de integração já se encontra em curso nas oficinas da doutrina brasileira já conseguiu divisar no tratamento da função social como vimos com MARTINS-COSTA, Bueno de GODOY, Gustavo TEPEDINO, THEODORO JÚNIOR e outros.

De todo modo não é desprezível o risco de alienação que correm os juristas, ainda que não por indolência, nem por razões de algibeira, ou mesmo simples covardia. Afinal, essa alienação, nas palavras de Buarque de HOLANDA, também "corresponde bem ao intelectualismo excessivo de nosso século, em que as ideias suplantaram violentamente os fatos, em que os conceitos formados da realidade substituíram-se à realidade" ${ }^{\# 7}$.

É bastante oportuno aqui o fenômeno lembrado por Fabio Konder COMPARATO a propósito do "incontestável divórcio entre o Direito e a realidade social":

(...) a verdadeira dissociação se apresenta não tanto entre o Direito em geral e a realidade social, mas entre um direito nobre e oficial, o único admitido nas discussões acadêmicas e nos debates doutrinários, e um direito menos qualificado ou de segundo grau, destinado a completar e corrigir o primeiro, e de cuja elaboração e interpretação se incumbem exclusivamente os práticos. ${ }^{158}$

A ideologia que molda as instituições jurídicas não nasce naturalmente. Essas instituições são forjadas e é por isto que atuar juridicamente é operar também política econômica, especialmente quando se modulam as relações contratuais, como lembra Edmilson COSTA:

\footnotetext{
${ }^{155}$ BUARQUE DE HOLANDA, Sérgio. Poesia e crítica. In: O homem cordial. São Paulo: Penguin Classics Companhia das Letras, 2012, p. 39.

156 BARCELlONA, Pietro. Postmodernidad y Comunidad: El regreso de la vinculación social. $3^{\mathrm{a}}$ ed. Madrid: Editorial Trotta, 1999, p. 136.

${ }^{157}$ BUARQUE DE HOLANDA, Sérgio. op. cit., p. 40.

${ }^{158}$ COMPARATO, Fabio Konder. O Indispensável Direito Econômico, p. 453-454.
} 
Engana-se quem pensa que os velhos neoliberais (Hayek, Friedman, entre outros) estavam de braços cruzados esperando uma conjuntura favorável para expor melhor suas ideias. O neoliberalismo não caiu do céu: nenhuma ideologia brota rápido como cogumelos após a chuva. Esse pessoal trabalhou duro: a) formou pacientemente nas universidades em que tinham influência centenas e centenas de estudantes da periferia no mais puro ortodoxismo e a prova disso é que posteriormente os então estudantes passaram a exercer cargos de mando em seus países e transformara-se em implementadores da política neoliberal; b) manteve o núcleo operacional do FMI tão ortodoxo quando os mais expressivos professores de Chicago; c) consolidou uma produção teórica que, mesmo sem grande difusão pública no período, serviu para consolidar a ideologia neoliberal e para manter as tropas unidas até o momento propício para a escalada ao poder. (...)

A oportunidade emergiu com a crise do Welfare State e a ascensão do novo bloco de forças do grande capital ao poder nos Estados Unidos e na Inglaterra. Nesses dois países viviam os principais teóricos da nova ideologia e não foi difícil formar suas equipes para implantar a nova ordem. Na periferia também não houve grande dificuldades: como um exército intelectual espalhado pelo mundo os monetaristas neoliberalistas nem sequer necessitaram da reconversão coercitiva dos burocratas no poder, pois já possuíam a massa crítica, treinada e ansiosa, para a aplicação de suas propostas. Aliou-se assim o poder econômico e a ideologia para reconfigurar o mundo à sua maneira. $\mathrm{O}$ receio de que a conjuntura pudesse mudar, talvez explique a pressa com que os tecnocratas monetaristas/neoliberais realizaram as tarefas de desmonte da antiga ordem e a imposição de um pensamento único como norma intelectual. Em raros momentos da história uma doutrina foi capaz de, em pouco tempo, não só se impor perante o mundo, mas implementar uma regressão social tão avassaladora como a que foi realizada nas duas últimas décadas. ${ }^{159}$

A interação entre a produção científica, técnica e social, e o mundo econômico certamente vai para muito além dos paulatinos processos de formulação ideológica, sendo comum e "natural" sua utilização deliberada pelas forças hegemônicas na economia, como lembra FURTADO:

[a]s ciências sociais ajudam os homens a solucionar problemas práticos de várias ordens, mas também contribuem para conformar a imagem do mundo que prevalece em certa sociedade. Assim, podem servir de cimento ao sistema de dominação social que legitimam. É frequente, portanto, que as estruturas de poder procurem cooptar os homens de ciência. ${ }^{160}$

O conflito de ideias a respeito do significado da expressão função social posta no art. 421 do Código Civil, transcende bastante o âmbito dogmático disputado pelos

${ }^{159}$ COSTA, Edmilson. A globalização e o capitalismo contemporâneo. São Paulo: Editora Expressão Popular, 2008, p. 200-201.

${ }^{160}$ FURTADO, Celso. Op. cit., p. 80. 
privatistas diante da verdadeira explosão que ocorreu com o negócio jurídico, o contrato, no mundo contemporâneo, como acertadamente observa COMPARATO:

A economia de massa contemporânea transformou o contrato de individual em coletivo. Coletivo, em primeiro lugar, quanto aos seus participantes ou, mais largamente, quanto aos seus dependentes: ele deixa de ser exclusivamente o instrumento de manifestação de vontades individuais na troca de bens ou serviços, para transformar-se em técnica de colaboração de empresas, profissões e sindicatos, entre si ou com Poder Público. Mas os contratos da economia de massa são também coletivos com relação à sua causa, pois eles tendem a integrar-se em quadros globais de programação ou de planejamento econômico. ${ }^{161}$

A atitude de COMPARATO é notável, pois praticamente deixou o posto de primeiro comercialista para entrosar sua técnica com reflexões mais amplas e compreensivas. Do direito comercial ao estudo da ética, um caminho obrigatório para a real utilização das técnicas do primerio visando à construção de uma sociedade mais justa $\mathrm{e}$ solidária, um dos objetivos da república, ao lado do desenvolvimento, postos no art. $3^{\circ}$ da Constituição Federal de 1988. ${ }^{162}$

Mas, diz a experiência concreta, o modo de produção do jurista nem sempre é esse, de coragem, abdicaçãoe abertura para a realidade. É muitas vezes mecânico, repetitivo, vinculado a interesses casuísticos, alienado. Mino CARTA, a propósito da independência e coragem com que Hannah ARENDT escrevera "A banalidade do mal", sofrendo crítica da comunidade à qual pertencia, expõe o paradoxo humano que parece dificultar o plantio da função social: inteligência e reflexão muitas vezes não se dão as mãos:

O homem é um bicho imperfeito, muito imperfeito, a gente sabe. Dispõe dos instrumentos para pensar, mas a maioria não sabe usá-los.A maioria felizmente não é de criminosos nazistas, mas é incapaz de fugas do clichê, do chavão, do lugar comum, da frase feita. Deste ponto de vista, a sociedade emergente do Brasil é imbatível, ipsis literis repete incansável as passagens mais candentes dos textos de jornalões e revistões enquanto os jornalistas aderem automaticamente às crenças dos seus patrões. $\mathrm{Na}$ terra da casa grande e senzala, a maioriavive ainda no limbo e os senhores jogam ao lixo o patrimônio do Brasil. O País, contudo, bate recordes nestas areias movediças. ${ }^{163}$

\footnotetext{
${ }^{161}$ COMPARATO, Fabio Konder. Op. cit., p. 468.

162 "Art. $3^{\circ}$ Constituem objetivos fundamentais da República Federativa do Brasil: I - construir uma sociedade livre, justa e solidária; II - garantir o desenvolvimento nacional; III - erradicar a pobreza e a marginalização e reduzir as desigualdades sociais e regionais; IV - promover o bem de todos, sem preconceitos de origem, raça, sexo, cor, idade e quaisquer outras formas de discriminação."

${ }^{163}$ CARTA, Mino. "Falta quem pense: porque as lições de Hannah Arendt também valem para o Brasil". Carta Capital. Ano XVIII, nº 761, 14 de agosto de 2013, página 16.
} 
No que tange aos contratos de seguro, só a quem fechar a mente e os olhos é que escapará a percepção de que ele não é um contrato privado típico que possa ser elaborado por suas partes com um mínimo de liberdade, nem um contrato que possa impunemente esgotar suas utilidades entre os contratantes. É um contrato com função tônica que exsurge da e para a socialidade que lhe é estruturalmente ínsita e que exige trato empresarial, não por conveniência ou lucratividade, não por lucro, mas porque a empresa, com a qual se funde, é inerente à operação de cada e de todos os contratos, como explica Valeria LORENZI, para quem a "empresa de seguro penetra na estrutura" e na "função do contrato de seguro" que é " função de utilidade, individual e social”:

A empresa de seguros e o uso da técnica securitária devem ser considerados essenciais ao contrato de seguro e caracterizam esse contrato. Que a empresa de seguros penetre na estrutura do contrato de seguro, nas prestações correspondentes das partes consta não apenas do prêmio, no sentido técnico, que deve pagar o segurado (prêmio médio, por grupo), mas também da indenização esperada (indenização esperada média, por grupo), a que o segurador se obriga a pagar.

A empresa de seguros penetra na função do contrato de seguro, porque sua presença, o uso dos cálculos técnicos e da técnica securitária são indispensáveis para alcançar as funções de utilidade individual e social do contrato de seguro: por sistematicamente assumir riscos de eventos economicamente desfavoráveis; por proteger o segurado individual, avesso ao risco, do custo da assunção do risco de um evento economicamente danoso; por congregar riscos independentes de eventos economicamente prejudiciais com o objetivo de reduzir o risco, ao máximo, nos grandes números, de sofrer neutralização econômica pelo risco total; por dividir e dispersar riscos de eventos economicamente desfavoráveis, para reduzir, ao máximo e, nos grandes números, eliminar o custo da assunção do risco. ${ }^{164}$

António Menezes CORDEIRO ressalta que há uma particularidade própria da supervisão e da regulação securitária pelo fato de não ser possível dissociarem-se os contratos de seguro das empresas seguradoras, uma imposição concreta, pois o equilíbrio

\footnotetext{
${ }^{164}$ LORENZI, Valeria De. Contratto di assicurazione - Disciplina giuridica e analisi economica. Padova: 2008, p. 42: "L'impresa assicurativa, l'utilizzo della tecnica assicurativa sono da ritenersi essenziali al contratto di assicurazione, caratterizzano il contratto di assicurazione. Che l'impresa assicurativa penetri nella struttura del contratto di assicurazione, nelle prestazioni corrispettive delle parti emerge non solo dal premio in senso tecnico, che deve pagare l'assicurato (premio medio, per gruppo), ma anche dall'indennità attesa (indennità attesa media, per gruppo), che si obbliga a pagare l'assicuratore. L'impresa assicurativa penetra nella funzione del contratto di assicurazione, perché la presenza della medesima, l'utilizzo delle misure tecniche, della tecnica assicurativa, sono indispensabili al fine di perseguire le funzioni di utilità, individuale e sociale, del contratto di assicurazione: per assumere sistematicamente rischi di eventi economicamente sfavorevoli, per sollevare il singolo assicurato, avverso al rischio, dal costo della sopportazione del rischio di un evento economicamente dannoso; per mettere in comune rischi indipendenti di eventi economicamente pregiudizievoli, nell'obiettivo della riduzione del rischio, al limite, su grandi numeri, della neutralizzazione economica de rischio totale; per dividere e diffondere rischi di eventi economicamente svantaggiosi, per ridurre, al limite, su grandi numeri, eliminare il costo della sopportazione del rischio."
} 
do sistema depende, na sua base, do conteúdo dos contratos celebrados, que exigem não só preciso dimensionamento entre as prestações, como adaptação à realidade, sob pena de "conduzir a desequilíbrios que, fatalmente, irão atingir o sistema":

O direito institucional dos seguros não se limita a regular as empresas seguradoras. A realidade em jogo leva a que ele se ocupe, também, dos próprios contratos de seguro.

(...)

O equilíbrio do sistema dos seguros manifesta-se no plano das seguradoras. Mas ele depende, na base, dos contratos que estas venham a celebrar. Contratos deseixados, mal dimensionados na relação prémio/risco coberto ou desadaptados da realidade sócio-económica em que funcionam podem conduzir a desequilíbrios que, fatalmente, irão atingir o sistema.

Dir-se-á que esse tipo de problema é comum a todos os sectores económicos, cabendo à concorrência reestabelecer o equilíbrio. Teoricamente, assim será. Mas a prática dos seguros revela dificuldades: os seguros têm um tipo de funcionamento diferido, de tal modo que a concorrência só se manifesta no longo prazo; ora, nessa altura, pode ser tarde para introduzir inflexões ou para mudar de seguradora.

Além disso, os contratos de seguro assentam em grandes números e numa normalização inevitável. Também aqui o funcionamento da concorrência, eficaz perante situações de atomismo do mercado, ou tarda ou é ineficaz. 165

Não há, por certo, como pensar-se individualmente cada contrato de seguro. Esse contrato reclama ser encarado em relação inseparável com as massas de contratos assegurados, e as estruturas de pulverização a que também as seguradoras recorrem (resseguro), e ter sua função social compreendida a casa instante, desde a concepção do seu conteúdo de garantia, passando pela precificação, pela execução dos procedimentos de regulação e liquidação dos sinistros, enfim, por todos os momentos da vida contratual.

${ }^{165}$ CORDEIRO, António Menezes. Direito dos Seguros. Coimbra: Almedina, 2013, p. 345. 


\section{Capítulo 3: Seguro, ReSSEguro e deSenvolvimento}

\subsection{Regulação e dimensão institucional do seguro no Brasil}

No Brasil, ao longo de décadas, o contrato de seguro foi regulado pelo Código Comercial imperial, de 1850, que trata dos seguros aplicados ao comércio marítimo, cujo título XIII (“Dos Seguros Marítimos”) vigora até os dias de hoje.

Depois, o seguro foi concorrentemente regulado, quanto aos chamados ramos terrestres, pelo Código Civil de 1916, que vigorou até 2003, quando passou a viger o Código Civil de 2002.

Embora o país não tivesse experiência significativa e suficiente para promover um regulamento jurídico autêntico e adequado, o Código Civil incorporou um capítulo sobre os seguros terrestres com cinco seções: a primeira continha as disposições gerais, a segunda, as obrigações e deveres dos segurados, a terceira, as obrigações e deveres dos seguradores, a quarta cuidava dos seguros mútuos e a quinta foi dedicada ao seguro sobre a vida.

O exame da dogmática jurídica aplicada ao contrato de seguro no Brasil não pode prescindir da compreensão de que o país convive com projetos para a superação do subdesenvolvimento econômico e social.

É nesse contexto desenvolvimentista que, no final dos anos 1930, o país passou a contar, no âmbito de uma política de industrialização, com o monopólio do resseguro pelo Instituto de Resseguros do Brasil (IRB), sociedade de economia mista vinculada ao Ministério do Trabalho, Indústria e Comércio, criada pelo Decreto-lei n. 1.186/1939, como uma das medidas nacionalistas do chamado "Estado Novo". Com o mesmo propósito fundaram-se, entre outras, a Companhia Siderúrgica Nacional (1940), a Companhia Vale do Rio Doce (1942), a Fábrica Nacional de Motores (1943) e a Hidrelétrica do Vale do São Francisco $(1945)^{166}$.

\footnotetext{
166 A respeito, ver Gilberto BERCOVICI: “O surgimento do IRB vinculado ao Ministério do Trabalho, Indústria e Comércio é explicado pela preocupação do Governo Vargas em nacionalizar o setor de seguros juntamente com a consolidação da seguridade social. O IRB será deslocado, com a criação do Ministério da Indústria e Comércio, no início da década de 1960, e, finalmente, em 1979, será transferido para o Ministério da Fazenda. A Constituição de 1988, ao inserir os setores de seguro e resseguro no sistema financeiro nacional (artigo 192, em sua redação original), retirou de vez qualquer vínculo do IRB com a seguridade, integrando-o definitivamente no setor financeiro de atuação estatal". Estado, resseguro e a industrialização
} 
O processo de funcionalização do seguro para a atividade econômica produtiva intensificou-se com a criação do Ministério da Indústria e Comércio, no início dos anos 1960.

Durante a ditadura militar que se impôs com o golpe de 1964, o modelo desenvolvimentista não sofreu transformações profundas ${ }^{167}$, ao contrário do que sucedeu com outras ditaduras sul-americanas ${ }^{168}$.

Nesse período, foi editado o Decreto-lei n. 73/1966, que dispõe sobre o chamado Sistema Nacional de Seguros e que regula as atribuições do IRB, cria a Superintendência de Seguros Privados (SUSEP), que é a autarquia federal fiscalizadora das operações, e o Conselho Nacional de Seguros Privados, que é o órgão normativo - na verdade um organismo que legitima normativas formuladas pela SUSEP -, ambos no âmbito do Ministério da Indústria e Comércio. Disciplinou também a relação entre esses órgãos da política estatal, e deles com as seguradoras, as retrocessionárias e os corretores de seguros.

O mencionado Decreto-Lei preocupa-se com o controle da atividade e é comumente designado por "Lei de Seguro". Contém poucas regras sobre o contrato, atinentes à sua formação, efeitos do inadimplemento do prêmio e possibilidade de correção monetária da importância segurada (arts. $9^{\circ}$ a 14).

Embora essas regras sejam destinadas, primordialmente, a proteger as seguradoras nos vínculos dos seguros massificados, o Decreto-lei n. 73/66 destaca a noção de interesse, de grande relevância para a eficácia garantidora dos seguros, fazendo-lhe expressa referência no $\S 2^{\circ}$ do art. 11:

brasileira. Separata de Liber Amicorum - Homenagem ao Prof. Doutor António José Avelãs Nunes. Coimbra: Coimbra Editora, 2009, p. 352.

167 Ver Paulo G. F. VIZENTINI: "Este projeto, cujas origens ideológico-estratégicas remontam ao movimento tenentista dos anos 20, foi impulsionado a partir dos anos 30 com Getúlio Vargas e, com avanços e recuos, prosseguiu durante o período populista entre 1945 e 1964 . Apesar do golpe de 1964 encerrar o ciclo nacional-desenvolvimentista do populismo, o processo de desenvolvimento industrial prosseguiu sob outras formas. A redemocratização, por sua vez, também não apresentou um ruptura significativa no modelo, o que só veio a ocorrer em 1990, com a adoção do projeto neoliberal na Era dos Fernandos, este sim descomprometido com o desenvolvimento nacional." ("Política externa e desenvolvimento no regime militar" in Princípios, n. 51, p. 56-65, São Paulo, nov-jan de 1998 a 1999.)

${ }^{168}$ VIZENTINI, op. cit.: "Do início da década de 60 ao fim da de 80 , a história brasileira foi marcada pela ascensão e queda do regime militar, que permaneceu no poder por 21 anos e alterou profundamente a sociedade brasileira. Estabelecer um balanço deste período é algo difícil, que poucos tiveram a coragem de fazer. Basicamente, o regime militar propôs-se e cumpriu dois objetivos básicos: construir um moderno capitalismo industrial e conter o movimento popular. Quanto ao primeiro aspecto, é preciso considerar que os militares deixaram o Brasil na posição de único país ao sul do Equador dotado de um completo e diversificado parque industrial, ao contrário de seus congêneres do Cone sul, que desindustrializaram seus países. Neste sentido, é preciso reconhecer que o regime manteve um projeto de desenvolvimento e a perspectiva de projeto nacional." 
“§ $2^{\circ}$ - Será lícito à Sociedade Seguradora argüir a existência de circunstância relativa ao objeto ou interêsse segurado cujo conhecimento prévio influiria na sua aceitação ou na taxa de seguro, para exonerar-se da responsabilidade assumida, até no caso de sinistro. (...)."

O elemento interesse não fora privilegiado no Código Civil de 1916, que silencia a respeito no art. 1432, onde define o contrato, e lhe faz remissão muito específica apenas para legitimar os seguros sobre a vida de terceiro (art. 1.472). Neste Código, o legislador parecia haver francamente optado pela compreensão de que o seguro protege a "coisa segura" (arts. 1437 a 1439, 1458, 1459, 1461 e 1463) e não a relação de interesse entre um sujeito de direito e os bens da vida.

Em termos similares, e mais gerais, o interesse já aparecia no Código Comercial de 1850, cujo art. 677 expressa: “O contrato do seguro é nulo: 1 - Sendo feito por pessoa que não tenha interesse no objeto segurado".

Independentemente do direito positivo, os seguros de danos, não apenas os atinentes a grandes riscos (riscos de engenharia, riscos operacionais etc.), mas principalmente estes, tendiam a coberturas amplas para a proteção dos interesses, nos textos das apólices, na jurisprudência e na doutrina.

A caracterização dos seguros como all risks, expressão entre nós utilizada tanto em sentido próprio para acolher o leque de riscos, quanto para exprimir a amplitude do interesse garantido, instala-se na compreensão jurídica e na prática securitária, sombreando os seguros de riscos nomeados.

Com isso, rumou-se para a maior eficácia garantidora dos contratos, e foi reforçada a ideia de que as exclusões e limitações de cobertura interpretam-se restritivamente:

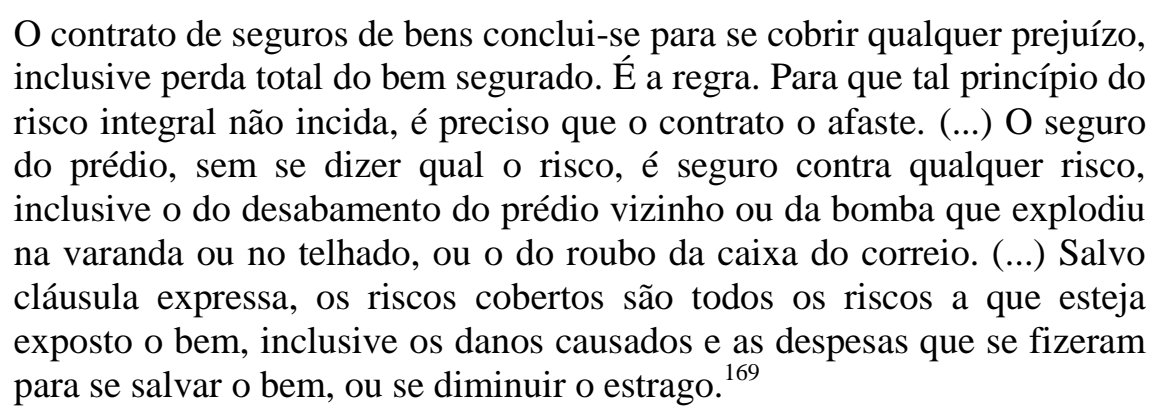

Em 1979, o ressegurador monopolista e a autarquia fiscalizadora foram transferidos do Ministério da Indústria e Comércio para o Ministério da Fazenda. O

\footnotetext{
169 PONTES DE MIRANDA, Francisco Cavalcanti. Tratado de Direito Privado, Rio de Janeiro: Borsói,
} 1958 , v. 45 , p. 344-345. 
desenvolvimentismo criador do conteúdo das nossas relações securitárias persistiu até o fim dos anos 1980 .

Nos anos 1980, os seguros brasileiros, notadamente os de riscos de engenharia e riscos operacionais, já haviam galgado qualidade superior aos congêneres latinoamericanos e equiparavam-se aos serviços securitários dos países centrais. A teoria do interesse já se amalgamara ao objeto do seguro para firmar a cultura de que o seguro garante os interesses do segurado relacionados aos empreendimentos.

O Código de Defesa do Consumidor, editado em 1990, não alterou significativamente o quadro de proteção dos segurados, pese os efeitos didáticos da campanha que sucedeu à sua edição, chamando atenção dos consumidores para seus direitos. Algumas conquistas que os tribunais haviam concedido aos segurados e beneficiários de contratos de seguro, como a ação direta da vítima contra o segurador de responsabilidade civil, foram até mesmo estorvadas pelo novo diploma, que somente autorizava agir contra o segurador em caso de quebra:

Art. 101. Na ação de responsabilidade civil do fornecedor de produtos e serviços, sem prejuízo do disposto nos Capítulos I e II deste título, serão observadas as seguintes normas:

(...)

II - o réu que houver contratado seguro de responsabilidade poderá chamar ao processo o segurador, vedada a integração do contraditório pelo Instituto de Resseguros do Brasil. Nesta hipótese, a sentença que julgar procedente o pedido condenará o réu nos termos do art. 80 do Código de Processo Civil. Se o réu houver sido declarado falido, o síndico será intimado a informar a existência de seguro de responsabilidade, facultando-se, em caso afirmativo, o ajuizamento de ação de indenização diretamente contra o segurador, vedada a denunciação da lide ao Instituto de Resseguros do Brasil e dispensado o litisconsórcio obrigatório com este.

No final dessa década, especialmente a partir do governo Sarney, o IRB começa a negligenciar o papel de ressegurador monopolista, o que se faz sentir enfaticamente nos anos 1990 e 2000, passando a atuar como um intermediário de resseguros facultativos nos chamados grandes riscos. De fato e apesar da lei, entrega a competência para regular e liquidar sinistros aos reguladores estrangeiros indicados pelos seus resseguradores internacionais. 
Entrementes, o seguro e o resseguro serão integrados ao Sistema Financeiro Nacional pelo artigo 192 da Constituição federal de 1988, que previa existência de um “órgão oficial ressegurador". 170

Atendendo ao interesse no exercício livre da atividade resseguradora e na privatização do IRB, o artigo 192, II sofre alteração pela Emenda Constitucional n. 13/1996, a qual retira do texto da Constituição a expressão "órgão oficial ressegurador". Finalmente, com a edição da Lei Complementar n. 126/2007, passa a ser permitida a atuação de resseguradores internacionais no país, colocando-se o IRB, com certos privilégios, entre os resseguradores locais (art. 22).

Não obstante na prática governamental o projeto nacional-desenvolvimentista tenha cedido passo, sucumbindo às metas do Fundo Monetário Internacional, Banco Mundial e Organização Mundial do Comércio, o que acabou por conduzir, como se verá adiante, à perda de qualidade dos seguros brasileiros, a redação sobrevivente do artigo 192 da Constituição Federal manteve a funcionalização dos seguros para a ordem econômica. Expressou, claramente, que o sistema financeiro, no qual se incluem seguro e resseguro, deve ser "estruturado de forma a promover o desenvolvimento equilibrado do País e a servir aos interesses da coletividade".

Permanece, portanto, a conformação constitucional das atividades seguradora e resseguradora aos princípios da ordem econômica e ao objetivo de promover o desenvolvimento nacional.

\subsection{Seguro e interesse}

Como mencionado no capítulo anterior, a ideia de interesse é bastante cara para a funcionalização dos seguros, pois potencializa sua transubjetividade e dá corpo ao conteúdo das coberturas e ajuda a promover a equivalência entre os sinistros e as indenizações e reembolsos a cargo das seguradoras.

Victor EHRENBERG, considerado pai do direito do seguro alemão, publicou em 1915 uma monografia - Das "Interesse" im Versicherungsrecht - a respeito de um dos temas mais importantes sobre a matéria, o interesse segurado.

\footnotetext{
${ }^{170}$ A redação original do artigo era a seguinte: “Art. 192. O sistema financeiro nacional, estruturado de forma a promover o desenvolvimento equilibrado do País e a servir aos interesses da coletividade, será regulado em lei complementar, que disporá, inclusive, sobre: (...) II - autorização e funcionamento dos estabelecimentos de seguro, resseguro, previdência e capitalização, bem como do órgão oficial ressegurador".
} 
EHRENBERG ensina que o conteúdo do contrato de seguro (Schadenversicherung) $)^{171}$ adquire sua determinação concreta pela combinação entre objeto e interesse. Para o jurista, o objeto é o bem econômico para o qual o seguro é voltado. ${ }^{172}$

Quanto ao interesse, embora seja uma palavra com diversos significados no âmbito do direito, observa que é possível extrair um núcleo duro de significado: na medida em que qualquer evento é colocado sob o ponto de vista do benefício (Nutzen) ou do dano (Schaden), da vantagem ou da desvantagem, é linguisticamente desencadeada a expressão "interesse", independentemente de se tratar de valores econômicos ou ideais (tal como o valor ideal de "interesse público", por exemplo). ${ }^{173}$

Observa que, embora o Código Civil Alemão não utilizasse o termo "interesse" de forma técnica, a Lei de Contrato de Seguro e o Código Comercial alemães utilizavam o termo num sentido bastante específico: interesse é uma relação, por força da qual alguém (o interessado) pode sofrer uma desvantagem patrimonial através de um evento previsto em um contrato de seguro. ${ }^{174}$

$\mathrm{O}$ autor explica que existe um interesse quando alguém pode sofrer uma desvantagem patrimonial. $O$ interesse só existe na medida em que se configura a possibilidade da desvantagem econômica, ou seja, a extensão e limites do interesse também envolvem a extensão dos possíveis danos e, portanto, a extensão da compensação no seguro. ${ }^{175}$

No sentido do direito de seguro, afirma EHRENBERG, o interesse é uma relação. Uma relação se constitui onde o contrato de seguro está concentrado em um objeto específico: trata-se de uma relação com esse objeto. ${ }^{176}$

Essa relação não é exclusiva de um titular de direitos, podendo existir diversos interesses sobre um mesmo bem da vida, o que leva o autor a enfatizar a importância da ideia de interesse por sua introdução no direito de seguro possibilitar o seguro de diversos tipos de interesse relacionados ao mesmo objeto - esse é seu primeiro e mais importante

\footnotetext{
${ }^{171}$ Schadenversicherung pode ser traduzido de forma ampla por seguro ou por "seguro de dano". Existe uma diferenciação na doutrina alemã entre seguro de dano e seguro de montante/soma. No primeiro, os danos devem ser cobertos. No segundo, que abarca o seguro de vida, por exemplo, o segurador só está obrigado a pagar a quantia estipulada em contrato, independentemente dos danos.

${ }^{172}$ EHRENBERG, Victor. Das "Interesse" im Versicherungsrecht. München, Duncker \& Humblot, 1915, p.3.

${ }^{173}$ Idem, p. 4.

${ }^{174}$ Idem, p. 4-5.

175 Idem, p. 6-7.

${ }^{176}$ Idem, p. 7.
} 
significado. É por essa razão que é necessário especificar o tipo de interesse que será segurado na celebração do contrato. ${ }^{177}$

Para o autor, o interesse também é de grande relevância para determinar-se o dano e apurar-se a responsabilidade da seguradora. $\mathrm{O}$ valor desses interesses de tipos distintos determina o possível prejuízo (dano) e, com isso, delimita a máxima compensação do segurador. Assim, se já se conhece esse valor no momento da celebração do contrato, sabese ao mesmo tempo o rendimento (Ertrag) máximo da compensação e é possível, portanto, determinar o prêmio de forma racional com base no tamanho do risco (classes de risco). Esse é o segundo significado do conceito de interesse. ${ }^{178}$

Com grande perspicácia, EHRENBERG já observava que é possível pensar um interesse segurado de forma abstrata, sem que haja um interessado concreto, e que isso é até mesmo necessário para o esclarecimento dos diversos tipos de interesse segurado, já que eles têm um caráter tipicamente independente da pessoa do interessado. Divisava também que se pode diferenciar o próprio valor do interesse a depender da situação em que se encontra esse ou aquele interessado. ${ }^{179}$

O autor também trata do fenômeno da pluralidade de interesses, esclarecendo que estes podem ser orientados a um mesmo objeto ou, de forma contrária, o mesmo interesse econômico pode ser atribuído a mais de uma pessoa, com expressão em direitos subjetivos idênticos ou diferentes. ${ }^{180}$

O jurista alemão também distingue que não são raras as vezes em que um interesse passível de seguro está na base de uma obrigação, como quando alguém se obriga a "assumir o risco" por um objeto segurado. ${ }^{181}$

EHRENBERG utiliza o termo "coisa" apenas para fins práticos, embora o interesse tenha a coisa, ou outros bens da vida, apenas como seu objeto, para definir a relação, diferenciando-se os interesses conforme o objeto segurado atenda às finalidades econômicas. ${ }^{182}$

\footnotetext{
${ }^{177}$ Idem, p .8.

${ }^{178}$ Idem, p. 8.

${ }^{179}$ Idem, p. 9.

${ }^{180}$ Idem, p. 10.

${ }^{181}$ Idem, p. 10.

${ }^{182}$ Idem, p.. 23. A advertência do autor sobre o fato de que utiliza a palavra coisa por mera conveniência prática é de grande importância, pois alguns textos apegam-se a essa palavra, prejudicando a compreensão daquilo que se assegura.

DONATI, Antigono. Los seguros privados - Manual de Derecho / Antigono Donati. Barcelona : Bosch, 1960, p. 221-223:“Ciertamente el interés es una relación, susceptible de valoración económica, entre un sujeto y una cosa apta a satisfacer una necesidad, a prestar una utilidad, o más brevemente una relación económica (quae inter est) entre un sujeto y un ben; su sumisión al riesgo no es requisito del interés sino de
} 
EHRENBERG distingue as três perspectivas pelas quais podem ser encarados os bens que fazem emanar os interesses.

A "coisa" - de acordo com sua substância - pode ser adquirida por uma soma em dinheiro ou por um valor patrimonial; ela também pode ser utilizada e render frutos. $\mathrm{O}$ primeiro caso é chamado pelo autor de interesse de substância e o segundo de interesse de aproveitamento. A distinção entre eles consiste em que a possibilidade de valorização se esgota de uma só vez no primeiro enquanto que a possibilidade de aproveitamento se renova ininterruptamente no segundo. A possibilidade de valorização da substância da "coisa" (também chamado de valor de troca) depende em grande parte da possibilidade de aproveitamento - atual ou futura - e, ao contrário, essa possibilidade de aproveitamento depende da existência da substância. Isso não significa igualar ambos os interesses - eles existem de forma independente, um ao lado do outro. $\mathrm{O}$ dono de uma casa pode ter dois interesses distintos: o de segurar a própria casa em razão de sua substância e em razão da possibilidade de perda de seu aluguel. Em caso de dano, o proprietário tem de ser restituído de ambos os valores. ${ }^{183}$

A terceira perspectiva se verifica quando alguém não tem interesse direto no destino de uma "coisa", que não tem interesse na substância ou no aproveitamento da "coisa", mas, apesar disso, tem o dever de compensar o dono da "coisa" em caso de dano e, portanto, o interesse na sua manutenção, quando então se está ante o chamado de interesse de responsabilidade. ${ }^{184}$

\footnotetext{
su asegurabilidad. Consistiendo en una relación entre un sujeto y un objeto determinado o cuando menos determinable, el interés sólo puede ser concebido de un modo subjetivo (por ejemplo: el interés de propiedad de Ticio sobre una cosa); una concepción objetiva está en contradicción lógica con cualquier definición del interés que siempre tiene una base subjetiva; es absolutamente incompatible con el concepto y la función del seguro, como se ha mantenido desde un principio; está en contradicción con la normas de derecho positivo de todos los países y en particular con las del seguro por cuenta y sobre la transmisión de la relación aseguradora en caso de enajenación de la cosa asegurada. (...) La introducción del interés en la teoría del seguro constituye notable progreso con respecto a la fase que vería sólo el riesgo y la cosa: pero además pone la teoría de contrato de seguro al unísono con la teoría general que no considera objeto de tutela los bienes, sino los intereses; permite una concepción unitaria del seguro y su distinción del juego y la apuesta; explica la coexistencia válida de varios seguros, con respecto a intereses de naturaliza diversa sobre la misma cosa; permite una más rigurosa construcción de la teoría del valor y constituye la base de la estructuración del seguro por cuenta." Cf. p. 23. LA TORRE, Antonio. Le Assicurazioni. Milano. Giuffré Editore, 2000, p. 141. Luigi FARENGA esclarece que "[o] interesse é normalmente representado como a relação de caráter econômico que liga o bem, objeto do seguro, ao segurado. O interesse é, portanto, o elemento que identifica o segurado, como titular do interesse, e, ao mesmo tempo, por sua intensidade, determina o valor da coisa." FARENGA, Luigi. Diritto delle Assicurazioni Private. Torino: G. Giappichelli Editore, 2001, p. 104: "L'interesse viene normalmente rappresentato come la 'relazione di carattere economico' che lega il bene, oggetto dell'assicurazione, all'assicurato. L'interesse è dunque l'elemento che identifica l'assicurato, in quanto titolare dell'interesse, e nel contempo, attraverso la sua intensità, misura il valore della cosa.

${ }^{183}$ Idem, p. 23.

${ }^{184}$ Idem, p. 26-7.
} 
O interesse, enfatiza-se, é fundamental para definir a qualidade de segurado, e parte essencial do conteúdo dos seguros, como a garantia, a lesão a ser indenizada e da indenização.

\subsection{Função desenvolvimentista do seguro e do resseguro}

Independentemente da corrente ideológica a que se alinhem, juristas, economistas, cientistas sociais e todos os demais que se debruçam sobre o seguro reconhecem que ele existe para a sociedade e promove o desenvolvimento econômico e social.

São diversos os ângulos pelos quais pode ser apreendida essa funcionalidade securitária. VAUGHAN e ELLIOT, por exemplo, enfatizam a otimização da "produtividade do capital" que o seguro promove. Sem o seguro, afirmam, os indivíduos e as empresas são obrigados a precaverem-se e para isso devem tornar ineficiente o uso do capital com o objetivo de formar reservas. A liberação da necessidade dessas poupanças individuais que o seguro proporciona libera o capital para investimentos muito mais produtivos:

O seguro também propicia uma utilização mais favorável do capital. Sem a possibilidade de seguro, indivíduos e negócios seriam obrigados a manter uma reserva de fundos relativamente grande para fazer frente ao risco que devem assumir. Esses fundos estariam sob a forma de dinheiro ocioso, ou seriam investidos em títulos seguros, de alta liquidez e baixo rendimento. Isso seria um uso ineficiente do capital. Quando o risco é transferido para o portador professional de risco, os desvios dos resultados esperados são minimizados. Como consequência, os segurados são obrigados a manter reservas muito menores do que seria o caso se o seguro não existisse. Os fundos liberados tornam-se então disponíveis para investimento em atividades mais produtivas, resultando numa produtividade bem maior do capital. $^{185}$

HANSEL também acentua que, para precaverem-se contra a ruína que um acidente pode provocar, os empresários prudentes são obrigados a inercializar parte importante de seu capital. O seguro viabiliza a alforria desse capital para a produção e o desenvolvimento das atividades empresariais e, além disso, inspira confiança indispensável

185 Emmett J. VAUGHAN e Curtis M. ELLIOTT. Fundamentals of risk and insurance: 2.ed., Nova Iorque, John Wiley \& Sons, 1978, p. 48. Original em inglês: "Insurance also provides for a more optimal utilization of capital. Without the possibility of insurance, individuals and businesses would be obligated to maintain relatively large reserve funds to meet the risk that they must assume. These funds would be in the form of idle cash, or would be invested in safe, liquid, and low-interest-bearing securities. This would be an inefficient use of capital. When the risk is transferred to the professional risk bearer, the deviations from expected results are minimized. As a consequence, insureds are obligated to keep much smaller reserves than would be the case if insurance did not exist. The released funds are then available for investment in more productive pursuits, resulting in a much greater productivity of capital." 
para a realização de muitos empreendimentos que se encontram sujeitos a riscos que podem levar os investidores à ruína:

Nenhum industrial prudente consideraria investir grandes somas de dinheiro num projeto sem alguma garantia apropriada. Na ausência de seguro, uma delas poderia ser um fundo de reserva substancial, de tal maneira que o infortúnio não trouxesse uma ruína financeira. $\mathrm{O}$ seguro tem o efeito de liberar essas reservas para novos investimentos e desenvolvimento. Isso promove o comércio e a indústria.

$[\ldots]$

O mundo dos negócios também se beneficia da confiança que o seguro inspira. Sem seguro, muitos empreendimentos sequer começariam, pois os envolvidos dificilmente se arriscariam à ruína financeira causada por incêndios acidentais etc. ${ }^{186}$

186 D. S. HANSEL. Introduction to insurance. Londres: LLP, 1996, p. 8. Original em inglês: "No prudent industrialist would consider investing large sums of money in a project without some suitable safeguards. In the absence of insurance, one of these might be a substantial reserve fund, so that misfortune would not bring financial ruin. Insurance has the effect of releasing these reserves for further investment and development. This promotes trade and industry.

(...)

The business world also benefits from the confidence which insurance inspires. Without insurance, many business ventures would never begin, as those involved would scarcely risk financial ruin by the chance happening of fire, etc."

DICKSON e STEELE também ressaltam o estímulo para o desenvolvimento da empresa em que consistem a diminuição da necessidade de reservas e a confiança proporcionadas pelo acesso ao seguro: "The main stimulus to enterprise is the release of funds, now available for investment in the productive side of a business, which would otherwise be held in easily accessible reserves if the firm had not transferred the risk to an insurer. Medium and large sized firms would probably create reserve funds for emergencies which might put their whole future viability in jeopardy. While these funds could be invested it would be imprudent to invest any sizeable part of them in the business and the rate of return which could be obtained externally for quickly realizable investments would be less than if the money were available for internal investment. The premium payable to an insurer, however, would only be a small proportion of the fund required because of the pooling arrangements, and so most of this money could be invested in new plant, buildings or stock. (...) In the small firm, the security from loss which insurance provides means that losses which would be crippling can now be faced with confidence. Even in the larger firm, the executives can concentrate on their proper function of running an efficient enterprise. They can concentrate on the production and trading risks without the worry that the objectives in these fields may not be achieved due to fire or other insurable risk." (G. C. A DICKSON e J. T. STEELE, Introduction to insurance. 2. ed, Londres, Financial Times, 1984, p. 44-45) Tradução livre: “O principal estímulo para a iniciativa empreendedora é a liberação de fundos, agora disponíveis para investimento no ladoprodutivos de um negócio, que de outra maneira seriam mantidos em reservas facilmente acessíveis se a firma não tivesse transferido o risco para uma seguradora. Empresas de médio e grande porte provavelmente criariam fundos de reserva para emergências que poderiam pôr em risco toda sua viabilidade futura. Ainda que pudessem investir esses fundos, seria imprudente investir parte considerável deles no próprio negócio e a taxa de retorno que poderiam obter externamente com investimentos rapidamente realizáveis seria menor do que se o dinheiro estivesse disponível para investimento interno. O prêmio pagável para uma seguradora, entretanto, seria apenas uma pequena parcela do fundo requerido, graças à combinação [pooling] de recursos, e portanto a maior parte desse dinheiro poderia ser investido em novas instalações, prédios ou estoque.

$[\ldots]$

$\mathrm{Na}$ firma pequena, a segurança que o seguro oferece frente a prejuízos significa que perdas que incapacitariam essa firma podem agora ser encaradas com confiança. Mesmo na firma maior, os executivos podem se concentrar na sua função própria de gerir uma empresa eficiente. Eles podem concentrar-se nos riscos de produção e de comercialização sem a preocupação de que os objetivos nesses campos possam não ser alcançados devido a um incêndio ou a outro risco segurável." 
Para LARRAMENDI, PARDO e J. CASTELO esse "carácter liberador da segurança econômica que o seguro confere, no que respeita às tensões criadas pelo risco, permite considerá-lo como um fator importante do bem-estar social e do desenvolvimento da liberdade."187

São correntes na doutrina os destaques para a função desenvolvimentista e para os controles que devem ser exercidos com o objetivo de preservar essa "importante manifestação de solidariedade econômico e social" ${ }^{\text {188 }}$. Tanto é assim que autores como Amadeo Soler ALEU chegam a classificar a atividade seguradora entre os "serviços públicos impróprios" por promoverem continuamente a satisfação de necessidades da sociedade mediante autorização e rígido controle estatais. ${ }^{189}$

Francisco BUSQUETS ROCA, salienta diversas funções cumpridas pelo seguro: (a) a função de estabilizar os preços substituindo o custo imprevisto dos sinistros pelo gasto previsível e relativamente modesto dos prêmios; (b) o fomento do desenvolvimento econômico em virtude da eliminação dos riscos seguráveis que permite criar, construir e montar projetos de grande envergadura e arriscados, como as obras de exploração offshore de óleo e gás; (c) a substituição dos ativos perdidos com o sinistro e a consequente preservação das forças produtivas (d) a formação de reservas vultosas que são reinvertidas para financiar a criação de empresas e o desenvolvimento das atividades econômicas; (e) acumular experiência com a infortunística de forma a cooperar com a Administração Pública com estudos e medidas destinados à prevenção de acidentes, o que excede a função econômica de distribuição própria do seguro para convertê-lo em instrumento com função

187 I.H. de LARRAMENDI, J.A. PARDO e J.CASTELO. Manual Básico de Seguros, tradução de Maria Armênia de Sousa Vieira, Brasil, Edições técnicas, p. 17-18

188 “(...) Não é exagerado definir o seguro como uma importante manifestação de solidariedade econômicosocial. De acordo com esta ideia, quando alguém acha que está defraudando a companhia de seguros, não é realmente a ela que prejudica e sim ao resto da comunidade de segurados, que acabarão suportando o aumento do custo que representam os falsos sinistros ou as indenizações exageradas." I.H. de LARRAMENDI; J.A. PARDO e J. CASTELO, Manual Básico de seguros, tradução de Maria Armênia de Sousa Vieira, Brasil, Edições Técnicas, p. 19.

189 "Los servicios públicos impropios son aquellos que tienen en común con los propios satisfacer, en forma más o menos continua, necesidades sociales o colectivas, pero no es el Estado quien los presta ni los concede en explotación, sino que tan sólo los autoriza, permite y reglamenta.

El ejercicio de la actividad aseguradora consiste, pues, en la prestación de un servicio público impropio; por ello el Estado autoriza la prestación; a su vez, la reglamenta y, ejercitando sus poderes de policía, la controla. Para poder ejercer el comercio de los seguros es conditio sine qua non que el Estado otorgue la licencia pertinente y que el prestador del servicio - el asegurador - se someta a las normas que regulan la actividad aseguradora (ley 20.091). Si no presta adecuadamente el servicio público impropio, como, vgr., ante la pérdida de su capacitación económico-financiera, el Estado puede retirarle la licencia oportunamente otorgada, debiendo proceder a su liquidación." (Amadeo Soler ALEU. Seguro de Incendio. Buenos Aires: Editorial Universidad, 1980, p. 80-81.) 
produtiva; (f) contribui para o aperfeiçoamento do sistema de saúde e apriomora as condições sanitárias da coletividade, reduzindo a demanda da assistência estatal; (g) contribui para manter o espírito de união da família, célula primária da vida social e da nossa organização econômica e (h) os de vida atuam como fator de estabilização monetária, na sua função de poupança, pois subtraem do consumo imediato o valor dos prêmios, que são canalizados para investimentos de largo prazo. ${ }^{190}$

Autores como François COUILBAULT, Constant ELIASHBERG e Michel LATRASSE classificam o seguro como um "fator de progresso", ressaltando sua grande relevância para os países em vias de desenvolvimento e a demanda de uma especial organização econômica, financeira e jurídica:

A história nos ensina que o desenvolvimento do seguro marítimo favoreceu o crescimento do comércio. Os marinheiros estavam em condições de financiar suas expedições graças à existência do seguro.

De maneira geral, todo progresso comporta a assunção de risco, que será melhor aceita, até mesmo tornada possível, se existirem mecanismos de compensação em caso de fracasso.

É notável como, em todos os países "em vias de desenvolvimento", tornase patente uma enorme necessidade de segurança.

Para certas atividades, o seguro é mesmo indispensável: assim, as empresas que desejam exportar não o podem fazer senão graças a seguros específicos. [...]

Parece também que o seguro, para florescer, necessita de uma sociedade organizada, tanto no plano econômico e financeiro quanto no plano jurídico. ${ }^{191}$

190 Francisco BUSQUETS ROCA, Teoría general del seguro, Barcelona, Vicens-Vives, 1988, p. 62-63: "El seguro, en su función de reparto de las consecuencias de los siniestros, contribuye a la estabilidad de los precios, por cuanto substituye, en la producción y distribución de los bienes, los gastos imprevistos y extraordinarios de los siniestros por el gasto regular de las primas, que representan una parte modestísima de los gastos fijos o proporcionales (según los casos) de cada empresa. El seguro fomenta el desarrollo económico, por cuanto, eliminando los riesgos asegurables, facilita la creación, construcción y montaje de complejos cada vez más arriesgados (piénsese en las grandes obras, las grandes industrias y, concretamente, en las plataformas petrolíferas del Mar del Norte) y, con su función indemnizatoria, permite la sustitución y reparación de los elementos siniestrados, sosteniendo la producción y los puestos de trabajo. Finalmente, la inversión de sus reservas, técnicas y patrimoniales, es fuente de financiación para el desarrollo de nuevas empresas industriales y agrícolas y la ampliación de las ya existentes. En su función de análisis, selección y tarifación de riesgos y la prevención de siniestros, sino que también, como Institución, dispone de una gran experiencia que le permite colaborar con el Estado y con sus instituciones en estudios de formas y medios de prevención e incluso promoverlos. En estos trabajos, el seguro supera la función económica de distribución para convertirse en productivo. El seguro en el plano social, ayuda también a mejorar la salud y las condiciones sanitarias de la colectividad, reduciendo la necesidad de la beneficencia pública (recordemos, como ejemplos, el Seguro de entierros y la selección médica en los Seguros de vida) y contribuye a mantener la unión y espíritu de la familia, que es aún la célula primaria de nuestra vida social y nuestra organización económica. El seguro de vida es un factor de estabilización monetaria, en su función de ahorro, pues retira sus primas del consumo inmediato y las canaliza hacia la inversión a largo plazo."

191 Constant ELIASHBERG COUILBAULT e Michel LATRASSE, Les grands principes de l'assurance, $5^{\text {a }}$ ed., Paris, L’Argus, 2002, p. 17. Original em francês : "L'histoire nous enseigne que le développement de l'assurance maritime a favorisé l'essor du commerce. Les marins étaient en mesure de financer leurs expéditions grâce à l'existence de l'assurance. D'une manière générale, tout progrés comporte une prise de risque qui sera mieux acceptée, voire rendue possible, s'il existe des mécanismes de compensation en cas 
O interesse público embalado nessa técnica preventivo-previdenciária que é o seguro privado reclama intensificada intervenção estatal, como reitera a doutrina sulamericana de STIGLITZ:

Se tiene expresado que, en materia aseguradora, la regulación estatal apunta a encauzar una actividad específica, en que convergen intereses vinculados no sólo con las economías privadas sino con la nacional, la producción en general y la confianza pública, por lo que se hace menester un control permanente que se extienda desde la autorización para opera hasta la cancelación.

(...)

Como se advierte, hay un interés público comprometido en la actuación de la empresa, por lo que el Estado debe ejercer un poder de policía, particularmente intensificado. ${ }^{192}$

HALPERIN também enfatiza a necessidade de uma vigilância mais forte nos países em vias de desenvolvimento, onde os serviços de seguro e resseguro constituem técnicas a serem aperfeiçoadas, que não se acham plenamente conhecidas e ajustadas às condutas sociais, nem lograram atuar mais plenamente para o cumprimento de suas funções essenciais:

De estos dos aspectos del seguro (su técnica y su función social) resultan los fines perseguidos por el control estatal, que halla actualmente la justificación en su proprio funcionamiento.

A) La técnica del seguro exige la formación de una masa homogénea de riesgos, cuyos titulares deben contribuir para habilitar al asegurador el pago oportuno de las indemnizaciones previstas, esto es, que el asegurador recibe una masa de capitales que debe invertir y reservar para afrontar sus obligaciones futuras eventuales o ciertas (vida)

De ahí que el primer fin del control estatal sea el de la capacitación económico-financiera del asegurador para cumplir con sus obligaciones existentes y o eventuales hacia los asegurados y sus beneficiarios.

B) Los fines sociales apuntados y la técnica de la producción fundada esencialmente en contratos tipo, realizada por grandes empresas de actuación nacional (e internacional), originan la necesidad de amparar a los asegurados con: 1) la regulación de condiciones equitativas de póliza; 2) precios adecuados a los riesgos asumidos; 3 ) cumplimiento diligente por el asegurador de las obligaciones contraídas.

En los países nuevos - como indica la experiencia argentina -, esta protección asume ciertas particularidades que no se dan en los de economía asentada. En los primeros, la buena fe aplicada al comercio es esquemática: se persigue el enriquecimiento rápido, aun con sacrificio de

d'échec. Il est remarquable de constater que dans tous les pays "en voi de développement", se fait jour un énorme besoin d'assurance. Pour certaines activités, l'assurance est même indispensable: ainsi les entreprises qui veulent exporter ne peuvent le faire que grâce à des assurances spécifiques.(...) Il apparait aussi que l'assurance, pour s'épanouir, nécessite une societé organisée, tant sur le plan économique et financier que sur le plan juridique."

192 Rubén S. STIGLITZ, Derecho de seguros, Tomo 1, 4ª ed., Buenos Aires, La Ley, 2004, p. $42-44$. 
una conducta leal; y ello se refleja sobre el espíritu de empresa. El empresario es, por lo general, improvisado: cambia de empresa según la productividad de ella, que se mide con el cartabón de la rapidez del enriquecimiento del empresario. El comercio del seguro no está libre de estos vicios. ${ }^{193}$

Conrado ETCHEBARNE, examinando, à luz do direito comparado, os fundamentos, a natureza e os sistemas legais de controle estatal sobre as empresas de seguro, conclui que a exigência de um regime especial de controle é consenso doutrinário universal, sendo esse controle indispensável para restabelecer o equilíbrio contratual para a proteção dos segurados e garantir a solvência do sistema:

La necesidad del control estatal en materia de seguros ha sido receptada con características de consenso general por la doctrina universal (...). Pienso que el panorama se clarifica si lo enfocamos desde los distintos ángulos que inciden en forma ineludible sobre la temática aseguradora, o sea, el contrato, el tráfico en masa, la técnica del seguro, la empresa aseguradora y la función social del seguro.

Desde el punto de vista del contrato de seguro, el objetivo y primordial del control es la protección de los asegurados, a fin de restablecer el equilibrio contractual que pudiera ser afectado por un sistema de libertad absoluta. (...)

La función técnica que constituye la operación aseguradora, forma expresiva del tráfico en masa, nos revela, a su vez, algunos matices distintos que se vinculan con la inversión adecuada de las sumas percibidas en concepto de prima, la observancia del régimen de reservas técnicas, los reaseguros y toda la normativa compleja que disciplina la solvencia de la empresa. Esta técnica peculiar del seguro lleva al profesor Halperin a indicar que el 'primer fin del control estatal sea de la capacitación económico-financiera del asegurador para cumplir sus obligaciones existentes y eventuales para con los asegurados y sus beneficiarios'. (...)

La intervención del Estado se explica aquí, según destaca el profesor de la Facultad de Derecho de París André Besson, en la medida en que el seguro, en relación con otros sectores de la vida económica, presenta la particularidad de la 'inversión del ciclo de producción'. (...)

La consideración de la empresa aseguradora, en cuanto representa una institución trascendente en el mercado de capitales y el instrumento para el cumplimiento de la función social del seguro, aporta nuevos fundamentos, no ya técnico-jurídicos sino de orden económico y político, al control del Estado. ${ }^{194}$

Como já indicado anteriormente, no Capítulo 1, Alessandro OCTAVIANI ressalta que esses fundamentos de ordem econômica e política enlaçados com o seguro submetem "toda regulação infra-constitucional sobre seguro, quer seja a regulação que determine os

193 Isaac HALPERIN e Nicolas Hector BARBATO. Seguros: exposición crítica de las leyes 17.418, 20.091 y 22.400. Buenos Aires: Lexis Nexis, 2003, p. 139-140.

194 Conrado ETCHEBARNE, El Control por el Estado de las Empresas de Seguro, Revista del Derecho Comercial y de las Obligaciones, Buenos Aires, 1970, p. 674-675. 
termos do contrato, a atuação da empresa ou a conformação do mercado" exigindo a "construção de um verdadeiro sistema orgânico de controle estatal" para "a proteção simultânea e articulada da (i) obrigação de garantia e (ii) manutenção de reservas técnicas, que organizam e orientam qualquer atuação de interpretação/aplicação do direito no campo do seguro". 195

Em suma, a socialidade do seguro, posta diante dos desafios concretos, exige uma proteção ampla e profunda que abraça não apenas a solvência da empresa de seguro como protege a obrigação de garantia que os contratos devem oferecer a fim de que cumpram não apenas o programa das vontades das partes faciais, nem tão só a proteção ocasional de terceiros, mas, na inteireza, a sua função-social.

Nosso modelo securitário, com monopólio de resseguro, foi desenvolvido para apoiar a política de desenvolvimento, em ambiente de intervenção típico do Estado de bem-estar social. Já o dissemos e adiante demonstraremos que os seguros de riscos de engenharia, importantes instrumentos para a execução da infraestrutura indispensável ao avanço econômico e social, chegaram a prover coberturas significativas (conteúdo com grande eficácia asseguradora), tanto nas apólices ${ }^{196}$, quanto nas regulações de sinistros ${ }^{197}$, processo positivo que começa a decair nas décadas do desmantelamento do modelo securitário brasileiro, e que tem apogeu em 2007 quando, finalmente, a Lei Complementar n. 126, de 15 de janeiro de 2007 dispõe sobre a abertura do resseguro, que se completará em 2008 com a regulamentação dessa mesma lei, e será selada no segundo semestre de 2013, com a privatização do IRB.

195 Voto do relator Alessandro S. OCTAVIANI Luis, CADE - Conselho Administrativo de Defesa Econômica, Ato de Concentração n ${ }^{\circ}$ 08012.005526/2010-39, 14.03.2012, p. 8-9.

196 Apólices são instrumentos probatórios dos conteúdos dos contratos de seguro emitidos unilateralmente pelas companhias seguradoras, em geral após o início de vigência dos contratos de seguro, cujo conteúdo é padronizado segundo as necessidades técnicas e atuariais apuradas pela seguradora e seus resseguradores. A respeito, ver TZIRULNIK, Ernesto e PIZA, Paulo Luiz de Toledo. Notas sobre a natureza jurídica e efeitos da apólice de seguro no direito brasileiro atual. Disponível em:

$<$ http://www.ibds.com.br/artigos/NotasSobreaNaturezaJuridicaeEfeitosdaApolicedeSeguronoDireitoBrasileir oAtual.pdf $>$

197 As regulações e liquidações de sinistros consistem nos procedimentos através dos quais as companhias seguradoras, em linha com seus resseguradores, utilizando seus próprios quadros ou recorrendo a profissionais especializados, prestam serviços destinados a identificar a etiologia dos eventos danosos e sua subsunção ao contrato de seguro, assim definindo a cobertura, bem como para identificar os interesses lesados e a quantificação da prestação devida ao segurado e/ou beneficiários com base no contrato de seguro. Ver TZIRULNIK, Ernesto e OCTAVIANI, Alessandro. Regulação de Sinistro (ensaio jurídico). $3^{a}$ ed. São Paulo, Max Limonad, 2001; THEODORO JÚNIOR, Humberto. A regulação do sinistro no direito atual e no Projeto de Lei n. 3.555, de 2004. In IV Fórum de Direito do Seguro José Sollero Filho. São Paulo: Instituto Brasileiro de Direito do Seguro, 2006, p. 183-215 e ROSS, H. Laurence. Settled out of Court - The social process of Insurance Claims Adnustments. $1^{\mathrm{a}} \mathrm{ed}$. Chicago: Aldine Publishing Company, 1970. 
A preocupação dos governos dos países periféricos com o sistema de resseguro decorreu não apenas de razões atinentes à proteção da economia no sentido da retenção dos fundos de prêmio, evitando evasão de divisas, e formação de poupança para a realização de investimentos.

Está na gênese da intervenção estatal no setor de resseguro a compreensão de que os contratos de seguro acham-se dependentes dos contratos de resseguro, que estes não apenas garantem financeiramente a execução daqueles, como também delimitam seus conteúdos, tornando-os mais ou menos úteis e eficazes para a sociedade, pois, como enfatizou Agamenon MAGALHÃES, “[c]om o desenvolvimento das actividades e do commercio, não era mais possível que o seguro pudesse corresponder à sua funccão social e econômica, sem resseguro". ${ }^{198}$ No mesmo sentido, cuidando da formação do mercado argentino, empreendida entre 1946 a 1952, Jorge S. ZAPPINO:

O seguro constitui a mais moderna instituição destinada a procurar a conservação da riqueza das nações, mediante a proteção de seu patrimônio econômico e humano, tornando possível a reconstrução ou a reposição do potencial produtivo destruído ou danificado por fatos eventuais previsíveis; permite, em consequência, a manutenção dos níveis de produção, transporte, consumo, moradia, etc., da economia em seu conjunto.

Dentro deste esquema, a atividade seguradora cumpre uma função econômica e social, pois não apenas garante a integridade patrimonial do país, mas também, pela técnica de sua própria operação, constitui um importante fator de formação de capital, ou seja, se transforma em uma espécie de poupança cujos fundos constitutivos são os prêmios pagos pelos segurados.

Esta massa de poupança é reinvestida no processo econômico, ao qual sustenta de suas maneiras: De um lado, indenizando as perdas ocorridas, e de outro investindo os fundos acumulados, que retém sob o rótulo de reservas para fazer frente, no momento necessário, ao pagamento das correspondentes indenizações.

Resulta lógico, então, que dentro de um processo de desenvolvimento e independência no terreno econômico, as nações busquem o crescimento e consolidação de seu mercado segurador, como um meio para contar com uma adequada proteção do seu patrimônio nacional e de evitar a drenagem de divisas que representa a contratação de seguros no exterior, mantendo dentro das fronteiras nacionais o maior volume possível de prêmios, os quais se transformam, como já dissemos, em investimentos que reingressam no fluxo econômico. Esta importante função do resseguro marca transcendência do tema dentro do contexto da política econômica de países subdesenvolvidos como a Argentina, já que o caráter internacional dessa atividade determina necessidade de evitar que se "importe" resseguro do exterior sem haver saturado previamente a capacidade local de absorção de riscos.

198 "Respostas às críticas feitas em um memorial anonymo, distribuído pelos interessados contra a nacionalização" in O Anteprojeto de nacionalização das sociedades de seguros e o Instituto de Seguros, 1936, p. 45. 
IRUKWU, abordou, na década de 1970, as vantagens e justificativas para a criação de institutos nacionais de resseguros pelos países do chamado Terceiro Mundo, que na época foi estimulada pelas Nações Unidas por meio da Conferência das Nações Unidas sobre Comércio e Desenvolvimento. Dentre as justificativas da atividade ressecuritária empreendida pelos Estados da periferia, o autor indica que o resseguro é extremamente necessário nesses Estados, especialmente em razão de planos de desenvolvimento que ensejavam a demanda crescente de seguros e, consequentemente, de resseguros. ${ }^{199}$

A transcendência desta função se verifica na expressão: "quem controla o resseguro, controla o seguro", utilizada frequentemente no jargão da atividade uma vez que o respaldo ressegurador é indispensável para possibilitar as empresas de seguros a aceitação da cobertura de grande parte dos riscos, ou determinar eventualmente sua recusa. $^{200}$

\section{Temos insistido que}

[o]s seguros, como seus funcionais resseguros, servem à solidarização e ao desenvolvimento econômico e social do país, não podendo ser transformados em instrumento de discriminação ou de constrangimento

\footnotetext{
199 "Reinsurance institutions are generally created in order to achieve a higher national retention and hence to reduce the foreign exchange outflow due to reinsurance. They are badly needed in developing countries, especially as almost all of these countries have development programmes which are generating increasing demand for insurance and, naturally, for reinsurance protection." IRIKWU, J. O. Reinsurance in the Third World. Londres: Witherby \& Co. Ltd., 1982, p. 11-12.

${ }^{200}$ ZAPPINO, Jorge S. El Instituto Mixto Argentino de Reaseguros - La formación de un mercado nacional de seguros (1946-1952), $1^{a}$ ed., junho 2007, Buenos Aires: Argentina, p. 20-21. "El seguro constituye la más moderna institución destinada a procurar la conservación de la riqueza de las naciones, mediante la protección de su patrimonio económico y humano, haciendo posible la reconstrucción o el reemplazo del potencial productivo destruido o dañado por hechos eventuales previsibles; permite, en consecuencia, el mantenimiento de los niveles de producción, transporte, consumo, vivienda, etc., de la economía en su conjunto. Dentro de este esquema, la actividad aseguradora cumple una función económica y social, ya que no sólo garantiza la integridad patrimonial del país, sino que, por la técnica de su propia operatoria, constituye un importante factor de formación de capital, es decir, se transforma en una forma de ahorro cuyos fondos constitutivos son las primas pagadas por los asegurados. Esta masa de ahorro se reinvierte en el proceso económico, al cual nutre de dos maneras: por una parte, indemnizando las pérdidas ocurridas, y por otra invirtiendo los fondos acumulados, que retiene bajo el rótulo de reservas para hacer frente, en el momento necesario, al pago de las correspondientes indemnizaciones. Resulta lógico entonces que, dentro de un proceso de desarrollo e independencia en el terreno económico, las naciones busquen el crecimiento y consolidación de su mercado asegurador, como un medio para contar con una adecuada protección de su patrimonio nacional y de evitar el drenaje de divisas que representa la contratación de seguros en el exterior, manteniendo dentro de las fronteras nacionales el mayor volumen posible de primas, las cuales se transforman, como ya dijimos, en inversiones que reingresan al flujo económico. Esta importante función del reaseguro, marca la transcendencia del tema dentro del contexto de la política económica de países subdesarrollados como la Argentina, ya que el carácter internacional de esta actividad determina la necesidad de evitar que se "importe" reaseguro del exterior sin haber saturado previamente la capacidad local de absorción de riesgos. La transcendencia de esta función se verifica en la expresión: "quien maneja el reaseguro, maneja el seguro", utilizada frecuentemente en la jerga de la actividad, dado que el respaldo reasegurador resulta indispensable para posibilitar a las empresas de seguros la aceptación de la cobertura de gran parte de los riesgos, o determinar eventualmente su rechazo."
} 
da atividade econômica. As recusas imotivadas de propostas podem levar a isso, seja excluindo setores da sociedade (por razões como local de moradia, poder aquisitivo etc.), seja discriminando atividades econômicas (fabricantes de móveis, têxteis etc.) ao sabor do chamado "apetite" dos resseguradores e seguradores, seja prejudicando empresas para as quais a contratação de seguros é vital (tomadoras de eurobonds, emissoras de ações negociadas em bolsa), seja privando de competitividade empresas que tecnicamente merecem ser seguradas. ${ }^{201}$

Não é em vão que entre as vinte regras para a regulação e supervisão das empresas de seguro e resseguro da Organização para a Cooperação e Desenvolvimento Econômico (OCDE) se tenham colocado a que enfatiza a necessidade de regras adequadas sobre os contratos de seguro, reconhecendo-as como essenciais para os cotnratantes e terceiros interessados e para o desenvovimento dos serviços (regra n. 5) e a aprovação, pelas autoridades, dos conteúdos das garantias oferecidas e das taxas para o cálculo dos prêmios (regra n. 10). ${ }^{202}$

Apesar de ser indiscutível a funcionalidadede dos contratos de seguro e da operação empresarial segurdora como um todo para servir de apoio ao processo de desenvolvimento, as circunstâncias históricas vividas nas últimas décadas acabaram por prejudicar a continuidade da proteção do desenvolvimento através dos seguros e resseguros no Brasil. Sofremos a despublicização do aparato criado para a política de desenvolvimento.

António José Avelãs NUNES ${ }^{203}$ menciona que a "reinvenção do estado mínimo" foi uma decorrência da crise dos anos 1970, quando

[o]s neoliberais aproveitaram a ocasião e, numa operação relâmpago de propaganda ideologica sem paralelo, colocaram Keynes, o 'estado keynesiano' e as políticas keynesianas no banco dos réus, culpando-os de todos os males do mundo" e com o "desmantelamento da União Soviética e da comunidade socilista, os neoliberais de todos os amtizes convenceram-se, mais uma vez, de que o capitalismo tinha garantida a

\footnotetext{
201 TZIRULNIK, Ernesto. "Contrato de Seguro: Arbitragem é Instrumento e não Função". Disponível em http://capitolio.com.br/opinioes/2013/05/09/contrato-de-seguro-arbitragem-e-instrumento-e-nao-funcao/ Acesso em 16 novembro 2013.

202 OECD Proceedings: Insurance regulation and supervision in economies in transiction: second east-west conference on insurance systems in economies in transiction. Paris: OECD, 1997, p. 54: "Rule n.5. Adequate insurance contract laws should be established. Rules governing contractual rights and obligations as well as related sanctions, are essential for the protection of both contractual and third parties and indispensable for the development of legal stability. In the absence of contract laws, the approval of policy conditions by the supervisory authority may prove all the more necessary." "Rule n.10. Initially at least, it may be advisable for economies in transition to request the submission of premium rates and insurance products for prior approval. Supervision of tariffs and products should however be adapted to the particular situation of each country and reassessed at a later stage according to the development and progress of the market."

203 A crise atual do capitalismo. São Paulo: RT, 2012, p. 20.
} 
eternidade, podendo regressar impunemente ao 'modelo' puro e duro do século XVIII.

Lembra o jurista português que:

Reinventado o estado mínimo, o estado capitalista muniu-se de outras armas, para cumprir o seu papel nas condições históricas das últimas três ou quatro décadas. Anti-keynesiano, apostou na privatização do setor público empresarial; na destruição do estado-providência; na criação das condições para a hegemonia do capital financeiro; na plena liberdade de circulação de capitais; na liberdade da 'indústria' dos 'produtos' financeiros, criados em profusão, sem qualquer relação com a economia real, apenas para alimentar os jogos de azar jogados nas bolsas-casinos; $(\ldots)^{204}$

Novamente, Avelãs NUNES, salientando o empenho das agências internacionais para o desmantelamento das estruturas estatais e contenção das políticas redistributivas que caracterizam as polítics desenvolvimentistas:

No rescaldo das dificuldades da primeira metade da década de 1970, o consenso keynesiano foi substituído pelo chamado Consenso de Washington, o consenso entre os EUA e as agências internacionais relacionadas com a economia (FMI, Banco Mundial e GATT/OMC), que se enquadra na estratégia para travar aquela perigosa tendência no sentido da baixa da taxa de lucro.

Trata-se de um consenso no sentido de impor ao mundo o catecismo monetarista e neoliberal: a liberdade plena de circulação de capitais; a desregulamentação dos mercados de capitais, incluindo o mercado de divisas; o combate prioritário à inflação e a desvalorização das políticas de promoção do emprego; a privatização das empresas públicas, incluindo as que produzem e fornecem serviços públicos; a adopção de políticas tributárias favoráveis aos muitos ticos e às grandes empresas; a rejeição de qualquer ideia de equidade e de quaisquer políticas de redistribuição do rendimento em favor dos titulares de rendimentos mais baixos; a flexibilização do mercado de trabalho e a contenção ou redução dos salários reais, num mundo em que a mundialização do mercado de trabalho significou um aumento enorme do exercício de reserva de mãode-obra e constituiu um estímulo poderoso à deslocalização de empresas, em busca de mão-de-obra mais barata e sem direitos.

A reaganomics nos EUA e o tatcherismo no Reino Unido marcam, a partir de 1979, o início deste novo ciclo, em que a ideologia neoliberal se confirmou como a ideologia dominante, a ideologia das classes dominantes (mais especificamente, a ideologia do setor dominante das classes dominantes: o setor financeiro). ${ }^{205}$

O movimento liberalizante de cunho notoriamente imperialista, que contava com a necessidade de desmontarem-se os aparatos estatais vinculados a políticas nacionais de desenvolvimento também é registrado por HOBSBAWM:

204 Idem, p. 20.

205 Op. cit., p. 30 e 35. 
Distribuição social, e não crescimento, dominaria a política do novo milênio. A alocação não mercantil de recursos, ou pelo menos uma implacável limitação da alocação de mercado, era essencial para desviar a crise ecológica iminente. De uma forma ou de outra, o destino da humanidade no novo milênio iria depender da restauração das autoridades públicas.

(...)

Não se podia prever o ritmo no qual avançariam as tomadas de decisões supranacionais. Apesar disso, certamente avançariam, e era possível ver como operariam. Já operavam, através dos gerentes de bancos globais das grandes agências internacionais de empréstimos, representando os recursos conjuntos da oligarquia dos países mais ricos, que também por acaso incluíam os mais poderosos. À medida que aumentava o fosso entre ricos e pobres, parecia que aumentaria o espaço para o exercício desse poder global. O problema era que, desde a década de 1970, o Banco Mundial e o Fundo Monetário Internacional, politicamente apoiados pelos EUA, vinham seguindo uma política sistematicamente favorecedora da economia de livre mercado, empresa privada e livre comércio global, que servia à economia americana de fins do século XX tão bem quanto servira à britânica de mercados do século XIX, mas não necessariamente ao mundo. Se as tomadas de decisões globais queriam realizar seu potencial, tais políticas teriam de ser mudadas. ${ }^{206}$

Esse movimento atuou de forma direta sobre a estrutura do Sistema Nacional de Seguros Privados, para forçar a implantação da máxima liberdade para os agentes hegemônicos do Mercado. Na matéria intitulada "FMI quer apressar abertura", publicada no Jornal do Commercio em 29 de março de 2002, é reportada a pressão exercida pelo Fundo Monetário Internacional sobre o governo brasileiro para extinguir o monopólio e privatizar o setor de resseguro:

O Fundo Monetário Internacional (FMI) aumentou as pressões sobre o Governo brasileiro para apressar o processo de abertura do mercado de resseguros, com a quebra do monopólio hoje exercido pelo IRB Brasil Re. Consultores do órgão estiveram, inclusive, oficialmente no Brasil, semana passada, para colher dados a respeito das atividades de seguros, resseguros, capitalização e previdência privada aberta. Apesar do aperto e do compromisso do Governo com o FMI para realizar a venda do IRB ainda este ano, o sentimento no mercado é de ceticismo quanto à abertura. Afinal, os seguradores entendem que o cumprimento de tal promessa está mais distante, em decorrência principalmente da demora do Supremo Tribunal Federal em julgar a ação de inconstitucionalidade impetrada pelos partidos de oposição, contra lei ordinária que dava poderes à Superintendência de Seguros Privados regulamentar o resseguro. Além do aspecto jurídico, há a questão política. Faltando pouco mais de sete meses para as eleições que definirão o sucessor do presidente Fernando Henrique, as autoridades parecem pouco inclinadas a gerar novo fato polêmico, através de uma privatização cuja necessidade já é questionada até mesmo por lideranças do mercado de seguros. Sem clima. O Governo sinaliza que pretende recorrer a novas medidas para

\footnotetext{
${ }^{206}$ HOBSBAWM, Eric. Era dos extremos. op.cit., p. 555-556.
} 
viabilizar a abertura do resseguro. Mas depende do Congresso Nacional aprovar a emenda constitucional que separa os sistemas de seguros e financeiro no artigo 192 da Constituição. Esta hipótese é vista no mercado com chances mínimas de materializar-se, considerando a ruptura do PFL com a base governista. Além disso, resta saber se o FMI não reclamará, pois essa alternativa não inclui necessariamente a venda do IRB. $^{207}$

Três anos depois, a matéria intitulada "A guerra pelo comando do IRB", publicada pela Revista IstoÉ Dinheiro em 16 de fevereiro de 2005, relata o movimento empreendido por governos estrangeiros reconhecidamente interessados na exportação de resseguros e o pano de fundo nacional envolvendo os conglomerados financeiros nacionais, notadamente Bradesco e Itaú-Unibanco, bem como a grave reação dos gestores da sociedade de economia mista. ${ }^{208}$

207 Disponível em http://www.revistacobertura.com.br/lermais_materias.php?cd_materias=51\&friurl=:FMI-quer-apressar-abertura-: Acesso em 23 de novembro de 2013.

${ }^{208}$ A guerra pelo comando do IRB

Coube ao primeiro-ministro da Alemanha, Gehard Schröder, pressionar o presidente Lula, em Davos, na Suíça, para que o Brasil abra com rapidez o mercado de resseguros. No Brasil, coube ao ministro Antônio Palocci anunciar que irá acabar com o monopólio do Instituto de Resseguros do Brasil (IRB) no setor. Palocci anunciou também que aceita discutir a privatização do IRB, estatal criada em 1939 com a função de pulverizar o risco das grandes apólices, como os seguros de aviões, navios e plataformas de petróleo. Da boca para fora, o mercado festejou. Afinal, Brasil e Cuba são os últimos países do mundo onde o resseguro é monopólio do Estado. "Essa é uma reivindicação antiga", diz João Elísio Ferraz, presidente da Federação Nacional de Seguradoras. Mas no mercado teve início imediato uma violenta guerra de bastidores. A primeira vítima foi o presidente do IRB, Lídio Duarte, que pediu demissão na véspera do Carnaval, por ser contra a privatização. "Se o governo deixar uma empresa estrangeira comprá-lo, será como entregar a Embraer para a Bombardier", disse ele à DINHEIRO. Ano passado, o IRB distribuiu US\$ 30 milhões em comissões às 23 corretoras credenciadas e teve um lucro líquido de $\mathrm{R} \$ 450$ milhões. $\mathrm{E}$ a guerra pelo destino do IRB é mesmo pesada. Em meados de 2004, o FMI começou a pressionar Palocci pela abertura do mercado de resseguros. O Itamaraty também está sendo pressionado pelos governos da Alemanha, Inglaterra e Estados Unidos. "Não devemos dar nosso ouro de presente, de graça", diz Luiz de Campos Salles, presidente da Itaú Seguros.

Em São Paulo, há ainda outra batalha de bastidores entre Bradesco, Unibanco e Itaú. Há cinco anos o Bradesco vem comprando ações do IRB no mercado. Hoje tem $42 \%$ das preferenciais e $22 \%$ do capital total. Por essa razão, nos últimos meses Unibanco e Itaú se juntaram a fim de convencer o ministro Palocci a quebrar o monopólio do IRB e enfraquecer a posição do Bradesco. A privatização não estava na pauta. A luta agora é para decidir o que virá antes - se a quebra do monopólio ou a privatização do IRB, temas distintos. O Bradesco aceita abrir o mercado para as companhias internacionais. Desde que a privatização venha antes. Assim, poderia vender suas ações para a alemã Munich Re, por exemplo, a maior do mundo. Com essa fórmula, o preço mínimo seria de R \$1,5 bilhão. A Fenaseg de João Elísio está com o Bradesco. Unibanco e Itaú querem que a abertura do mercado venha antes da privatização. Se isso ocorrer, as estrangeiras entrariam no País e as ações do Bradesco no IRB perderiam valor. A decisão agora está com o ministro Palocci. STUDART, Hugo. A guerra pelo comando do IRB. De 16 de fevereiro de 2005. Disponível em: http://www.istoedinheiro.com.br/noticias/11452 A+GUERRA+PELO+COMANDO+DO+IRB. Acesso em 12 de maio de 2013. 
O monopólio do ressseguro pelo IRB constituía instrumento fundamental da política securitária para o apoio ao desenvolvimento, como explica Gilberto BERCOVICI:

O papel estratégico do IRB para a economia nacional está também vinculado à proteção do mercado interno, constitucionalmente consagrada no artigo 219 da Constituição de 1988. Ao integrar o mercado interno ao patrimônio nacional, este artigo deve ser compreendido como um corolário da soberania econômica nacional (artigo 170, I da Constituição). O significado deste dispositivo é justamente a endogeneização do desenvolvimento tecnológico e a internalização dos centros de decisão econômicos, seguindo o programa de superação do subdesenvolvimento proposto por Celso Furtado e pela CEPAL e incorporados no texto constitucional de 1988. Afinal, desde as concepções da CEPAL, entende-se o Estado, através do planejamento, como o principal promotor do desenvolvimento. Para desempenhar a função de condutor do desenvolvimento, o Estado deve ter autonomia frente aos grupos sociais, ampliar suas funções e readequar seus órgãos e estrutura. O papel estatal de coordenação dá a consciência da dimensão política da superação do subdesenvolvimento, dimensão esta explicitada pelos objetivos nacionais e prioridades sociais enfatizados pelo próprio Estado. As reformas estruturais são o aspecto essencial da política econômica dos países subdesenvolvidos, condição prévia e necessária da política de desenvolvimento. Coordenando as decisões pelo planejamento, o Estado deve atuar de forma muito ampla e intensa para modificar as estruturas sócio-econômicas, bem como distribuir e descentralizar a renda, integrando, social e politicamente, a totalidade da população.

A abertura do setor securitário/ressecuritário ao capital estrangeiro e à maior participação da iniciativa privada não significa que o papel do IRB tenha diminuído de importância. Pelo contrário, a sua função de garantidor das operações securitárias, por meio do resseguro, bem como o seu papel na contenção e controle da evasão de divisas para o exterior são instrumentos fundamentais de que o Estado brasileiro não pode abrir mão, sob pena de comprometer todo o esforço histórico de décadas de construção e desenvolvimento de um parque industrial eficiente e autônomo no país." 209

O movimento do capitalismo internacional financeiro, atuando para o desmonte das estrutras estatais operativas do resseguro, afeta diretamente a vida contratual securitária. É importante ressaltar, desde logo, que é justamente o ressegurador que tem ascendência para a formulação do conteúdo dos contratos de seguro, notadamente dos contratos de seguro relacionados com os chamados riscos vultosos ou grandes riscos, como

\footnotetext{
209 Sobre a incorporação do ideário nacional-desenvolvimentista (e keynesiano) no texto da Constituição de 1988, vide Gilberto BERCOVICI, Desigualdades Regionais, Estado e Constituição, São Paulo, Max Limonad, 2003, p. 35-44, 54-67, 291-302 e 312-315; Gilberto BERCOVICI, "Estado, Soberania e Projeto Nacional de Desenvolvimento: Breves Indagações sobre a Constituição de 1988”, Revista Latino-Americana de Estudos Constitucionais n. 1, Belo Horizonte, Del Rey, janeiro/junho de 2003, p. 559-569 e Gilberto BERCOVICI, Constituição Econômica e Desenvolvimento: Uma Leitura a partir da Constituição de 1988, São Paulo, Malheiros, 2005, p. 45-68.
} 
são os seguros de riscos de engenharia, os seguros de riscos operacionais em geral e dos seguros de responsabilidade.

Maurício Andere von Bruck LACERDA, estudando os seguros brasileiros de responsabilidade civil dos administradores de sociedades empresárias, os chamados Directors \& Officers ou, simplesmente, D\&O, encontra-os sujeitos a padrões estranhos à realidade do país em razão da "forte influência dos $D \& O$ Insurance norte-americanos nas definições e no próprio padrão das contratações" ${ }^{\text {210 }}$, fato que o preocupa justamente porque subjaz o poder de comando dos resseguradores que são os verdadeiros conformadores dos conteúdos dos seguros:

Atualmente, é relevante e mercece destaque o patente dirigismo contratual promovido pelo setor ressegurador, que condiciona o resseguro de determinados contratos à adoção integral dos modelos de apólice e de questionário disponibilizados pelo próprio ressegurador que, além disso, estabelece o modus operandi e os outros dispositivos contratuais. Tais características acabam por confirmar a natureza de adesão de tais contratos, que dificilmente poderá ser afastada, em razão da baixíssima possibilidade de negociação do seu conteúdo. ${ }^{211}$

Enfim, é num cenário em que o resseguro brasileiro se estruturava como instrumento para a orientação da política de seguro, sendo o IRB personagem fundamental para a própria formação, controle e aperfeiçoamento dos conteúdos dos seguros, que o Brasil cedeu à política do estado mínimo ditada do centro para a periferia.

Sobreveio, como já vimos, a Lei Complementar n. 126/2007 para extinguir o monopólio de resseguro, com ele o modelo desenvolvido nas décadas de 1930 a 1960, e o IRB transformou-se em empresa privada a partir de $1^{\circ}$ de outubro de 2013 , tendo como controladores a BB Seguradora, a Bradesco Auto Re, a Itaú-Unibanco Seguros, a Itaú Vida e Previdência e o Fundo de Investimentos em Participações (FIP) Caixa Barcelona. A União detém golden share que não lhe atribui o poder de formular qualquer política de conteúdo técnico ou principiológico, conferindo-lhe apenas "direitos de veto nas deliberações sociais ou negócios jurídicos a respeito" (art. $8^{\circ}$, caput, dos estatutos sociais) da “definição das políticas de subscrição e retrocessão, representadas por normas de caráter

210 LACERDA, Maurício A von Bruck. O Seguro dos Administradores no Brasil - O D\&O Insurance Brasileiro, p. 253. Curitiba, Juruá, 2013.

211 A respeito da captura sofrida pelo IRB e empreendida pela AIG, associada à então Unibanco Seguros, ver nosso La póliza $D \& O$. In: III Jornadas de Reaseguro, 2005. Memorias de las III Jornadas de Reaseguro. México, DF: Swiss Re, 2005.

Nesse texto mostramos exemplo da grande liberdade com que, nas últimas décadas, os resseguradores estrangeiros atuaram como ghost writers do IRB e definiram de forma minuciosa o conteúdo dos seguros brasileiros. 
geral, sem indicação individualizada de negócios, devendo esse direito ser exercido de forma a se buscar o equilíbrio econômico-financeiro das carteiras correspondentes, salvo disposição expressa em acordo de acionistas do qual a União faça parte” (inc. IV).

Em suma, desaparece a sociedade de economia mista, criada em 1939, que na Constituição de 1988 recebera o título de “órgão ressegurador oficial", expressão suprimida do texto constitucional graças aos esforços das entidades representativas do financeirizado setor segurador privado, e com ela também desaparece o ressegurador comprometido e aparelhado com as competências necessárias para funcionalizar socialmente o conteúdo dos serviços de seguro (art. 44, revogado, do Decreto-lei n. 73/66).

\subsection{A intervenção estatal na doutrina sobre seguro: balanço crítico}

O processo da "financeirização" - na definição de Eros GRAU, a "arte de produzir coisa nenhuma que em si nada vale, mas vale mais do que o trabalho dos homens de bem" 212 -, para além de corromper o equilíbrio e a eficácia dos seguros coletivos de vida e acidentes pessoais, dos seguros de garantia estendida, dos seguros obrigatórios atinentes à infortunística do trânsito, do conjunto denominado microsseguro - ou seguro para micro-cidadãos -, entre outros, também atingiu os seguros atinentes aos riscos operacionais mais vultosos e os próprios seguros da construção da infraestrutura brasileira com a qual se declaram empenhados os governantes, culminando com o recente espisódio no qual as seguradoras brasileiras de Jirau, dirigidas pelas suas matrizes e resseguradores estrangeiros, não mediram esforços, nem pouparam recursos, para, ao menos, retirar da justiça estatal e do território brasileiro o assento de tribunal arbitral.

A compreensão de que importantes líderes do setor segurador têm a respeito da intervenção estatal é bastante particular e pode ser estereotipada com a doutrina de Luiz Tavares PEREIRA FILHO, bacharel em Direito, um dos mais experientes e bem sucedidos executivos do setor, vinculado ao maior grupo segurador brasileiro , ao seguro obrigatório automobilístico e ao IRB Brasil Resseguros S.A.:

“(...) o Seguro DPVAT, embora constitua modalidade de seguro privado, sofre superlativa intervenção do Estado, na medida em que: $50 \%$ dos prêmios brutos são carreados a órgãos da Administração Pública federal no ato de seu recebimento pela rede bancária; (...) De fato, nenhuma forma de intervenção do estado como empresário na atividade econômica

\footnotetext{
${ }^{212}$ Idem, p. 9.
} 
(empresa pública, sociedade de economia mista etc.) propiciaria uma receita direta e imediata correspondente a $50 \%$ dos valores brutos, sem participação em despesa alguma."213

Se, por um lado, chega a grassar nas principais lideranças do setor segurador essa visão de que a intervenção do Estado tem por único fim entesourá-lo, a qual também reflete o processo de aculturamento financeiro sofrido pelos governantes, por outro também os juristas, não só aqueles exânimes, sucumbem à pressão ideológica dos seguradores em combate.

Hoje Ministro do Supremo Tribunal Federal e antes parecerista de destaque no setor segurador, o jurista Luís Roberto BARROSO, em artigo intitulado "Natureza jurídica dos recursos que o custeiam", sustenta a legalidade da pífia eficácia indenizatória do DPVAT doutrinando que "trata-se de uma relação entre partes privadas - a seguradora e o contratante do seguro -, na qual não há subordinação jurídica entre elas e o interesse tutelado é, primeiramente, o dos próprios envolvidos, apenas que, por sua relevância e por conta de sua dispersão, tais interesses individuais acabam tendo um impacto social tão grande que o legislador decidiu instruir o contrato coativo." 214

Enfim, a relevância dada pela lei à obrigatoriedade do seguro, segundo o Ministro do Supremo Tribunal Federal, busca apenas promover sua contratação e o consequente pagamento do prêmio pelos proprietários, e não chega a penetrar no âmago do vínculo e reconhecer o interesse das vítimas dos acidentes de trânsito no contrato, nem os da sociedade em geral (interesse público) na dignificação da eficácia indenizatória. O impacto social leva apenas à obrigatoriedade da contratação, não à configuração interna dos contratos.

São inúmeros os exemplos de pretensas questões técnicas alarmantes, a convencer os juristas a opinarem em prol do enriquecimento do arcabouço jurídico protetivo das posições de interesse das seguradoras. Concordando com as críticas feitas por Fábio Konder COMPARATO na década de 1960 a decisões do Supremo Tribunal Federal que consideravam nulas ou ineficazes as cláusulas de rateio ou regras proprocionais dos seguros de danos ${ }^{215}$, por deprimirem o conteúdo esperado da obrigação indenizatória a

${ }^{213}$ PEREIRA FILHO, Luiz Tavares. Introdução. In: DPVAT - Um seguro em evolução. O Seguro DPVAT visto por seus administradores e pelos juristas. Rio de Janeiro: Renovar, 2013, p. 23.

${ }^{214}$ BARROSO, Luís Roberto. Natureza jurídica dos recursos que o custeiam. In: DPVAT - Um seguro em evolução. O Seguro DPVAT visto por seus administradores e pelos juristas. Rio de Janeiro: Renovar, 2013, p. 120.

${ }^{215}$ A cláusula de rateio tem por efeito diminuir proporcionalmente a indenização quando o valor da importância segurada é inferior ao valor do bem sobre o qual recai o interesse garantido. Para evitar que os 
cargo das seguradoras, Luis Gustavo HADDAD encontra aí um exemplo de aplicação do que considera "uma visão prospectiva e reguladora, que busca identificar os custos, ganhos e incentivos individuais e coletivos que serão gerados pelas duas ou mais decisões que podem ser tomadas". Sustenta que a função social do seguro estaria sendo violada por tais decisões, que elevariam as indenizações pagas pelas seguradoras, a superar os prêmios recebidos da coletividade segurada e tornaria "manifestamente inviável a empresa de seguros"216.

Verdadeira cruzada, que exigiu importantes investimentos, foi feita nos últimos três anos pelas companhias seguradoras contra o fantasma da destruição do sistema de seguro de responsabilidade civil diante da ação direta da vítima. Como já vimos, o incompleto fracasso foi festejado e é divulgado como absoluta vitória, enquanto a comunidade jurídica continua sustentando e aplicando a autonomia entre as pretensões das vítimas e as dos segurados contratantes do seguro de responsabilidade. Está aí presente, na raiz do discurso jurídico, a miopia social que têm ou optam por defender os arautos do liberalismo individualista, como há mais de meio século observava Abelardo Barreto do ROSÁRIO:

Na verdade, um único mérito há de ter tido essa nossa primeira investida no terreno da obrigação supletiva do segurador: o de enfocar em cores vivas e apaixonadas um problema a que nossos meios jurídicos não davam até então as primícias de uma discussão ou profundidade.

$\mathrm{O}$ primeiro grande obstáculo a transpor na ousada investida foi o da estraneidade da vítima nas relações contratuais estabelecidas entre segurado e segurador. Parecia infrangível aos olhos de juízes e doutrinadores o princípio res inter alios acta, a proteger, qual escudo romano, a viseira do segurador afortunado.

(...)

Falta-nos ainda, forçoso é reconhecer, uma noção exata do papel do seguro no mecanismo social. O seguro, para nós, está longe de ser o elemento pacificador e tranquilizador que justifica a sua contratação. Para isto, muito concorre um certo espírito de luta e de debate que anima e estimula o segurador, afugentando a confiança que em outros países já conseguiu impor à consciência dos cidadãos.

No dia em que tivermos da instituição do seguro a exata noção social que ele representa, em muito se reduzirão os pleitos judiciais e se poupará aos

segurados se habituem a assegurar por valores inferiores aos reais, elevando, assim, artificialmente a quantidade de perdas totais do interesse, e gerando desajustes na taxa desenvolvida para serem calculados os prêmios, em razão de se confundirem perdas parciais com perdas totais, faz-se a redução da indenização na mesma proporção em que se verificou o infrasseguro. A respeito, TZIRULNIK, Ernesto. $O$ contrato de seguro de acordo com o novo Código Civil. $2^{\text {a }}$ ed. São Paulo: Revista dos Tribunais, 2003, p. 117-120.

${ }^{216}$ HADDAD, Luis Gustavo, op. cit, p. 224-227. 
responsáveis diretos os percalços que por lei e pelo contrato devem recair sobre o segurador, como garantidor da obrigação. ${ }^{217}$

Voltando à preocupação de HADDAD com a regra proporcional e os prejuízos que seu afastamento poderiam causar para a estrutura dos seguros de danos, outrora invocados por COMPARATO, tal como ocorre com a abertura dos conceitos de riscos e danos indenizáveis nos seguros obrigatórios dos proprietários de veículos automotores temida por TEPEDINO ${ }^{218}$, passa-se o mesmo que Barreto do ROSÁRIO viu acontecer com a ação direta. Ela se transformou em cavalo de batalha do "espírito de luta e de debate que anima e estimula o segurador, afugentando a confiança". ${ }^{219}$

Com efeito, após ter-se consolidado na jurisprudência, independentemente da racionalidade matemática da cláusula de rateio proporcional, a vedação a essas regras havia levado, ao longo dos anos 1970 e 1980, as próprias seguradoras a reduzirem substancialmente seu uso. Assim optou o próprio setor segurador porque o uso do rateio causava grande litigiosidade e era perfeitamente possível evitar os prejuízos financeiros e de imagem, bastando para isso fazer uso dos chamados seguros a primeiro risco absoluto em que o rateio não se verifica. Ao invés de determinarem a inviabilidade da empresa seguradora, aquelas decisões sobre o rateio criticadas a partir do "raciocínio segundo as consequências", conduziram os negócios securitários a um menor grau de litigiosidade, reservando-se a regra proporcional para aqueles poucos seguros de riscos vultosos em que potencializam utilidade para as seguradoras, em caso de perdas parciais.

Todas essas questões se colocam ante um grande universo de pessoas, pois dizem respeito não apenas aos segurados que celebraram o seguro e que, portanto ocupam a posição de parte, tal como usualmente definida no contexto do contrato clássico para fruição e suportação dos efeitos internos ${ }^{220}$, nem tão só aos beneficiários instituídos pelos

${ }^{217}$ ROSÁRIO, Abelardo Barreto do. “Ação Direta da Vítima Contra o Segurador”. Rede Ferroviária Federal S.A. Estrada de Ferro Central do Brasil. Departamento Jurídico, Rio de Janeiro: 1967. Serviço de Divulgação, p. 1 e 11.

${ }^{218}$ TEPEDINO, Gustavo. "O problema da causalidade no seguro obrigatório por danos pessoais causados por veículos automotores de via terrestre (DPVAT)". In: DPVAT - Um seguro em evolução. O Seguro DPVAT visto por seus administradores e pelos juristas. Rio de Janeiro: Renovar, 2013, p. 339-40: ver a preocupação, a nosso ver exagerada, com a amplitude da casualidade protegida pelo seguro obrigatório automobilístico, a ser restringida "sob pena do colapso do sistema, dilacerado pela banalização do ressarcimento e o consequente encarecimento dos acidentes, refletidos nas apólices futuras, indenizados de forma não criteriosa."

${ }^{219}$ ROSÁRIO, Abelardo Barreto do. Op. cit., p. 11

${ }^{220}$ POPP, Carlyle. "A eficácia externa dos negócios jurídicos". In: LOTUFO, Renan e NANNI, Giovanni Ettore (coords.). Teoria Geral dos Contratos. São Paulo: ATLAS, 2011, p. 160: "Os efeitos internos, quais sejam, as obrigações contratuais stricto sensu, somente podem ser exigidos das próprias partes, pois 
estipulantes dos seguros, repercutindo efeitos positivos e negativos para todos que vivem em sociedade, como aqueles que porventura vierem a ser vítimas da infortunística do trânsito.

Qualquer brasileiro que vá contratar seguro tem interesse na amplitude das coberturas, na modicidade dos prêmios, na inexistência de cláusulas que causem surpresas e deprimam a prestação na seguradora no momento do sinistro. E cada um de nós quer que as obras de engenharia privadas e públicas, que nos trarão benefícios e avançarão o desenvolvimento nacional, sejam adequadamente protegidas por conteúdos contratuais eficazes e equilibrados.

Autor do primeiro projeto de lei de contrato de seguro da história do país, o atual Ministro da Justiça, José Eduardo Martins CARDOZO enfatiza a relevância social e econômica dos seguros ${ }^{221}$, o que remete à "dialética de complementariedade" invocada por Gerson Luiz Carlos BRANCO para explicar o convívio entre liberdade e função social, destacando a "importância que publicistas e civilistas dêem as mãos":

O seguro, enfim, é uma atividade que, embora não seja serviço público, pelas repercussões sociais que tem, dificilmente deixará de reclamar uma forte dose de atuação estatal. É, pois, de fundamental importância que publicistas e civilistas dêem as mãos e façam um diagnóstico preciso do papel do Estado no setor, dos seus direitos, dos seus deveres, de suas responsabilidades perante a sociedade. Obviamente, o seguro deve ser compreendido como um contrato de direito privado. Mas é um equívoco entender que o seguro também não está marcado por normas de direito público, por institutos de direito público, de maneira que sua compreensão requer o manejo dos conceitos próprios a este campo.

Sob a alegação de que o setor de seguros cresce vertiginosamente no Brasil, alguns postulam pelo imobilismo legislativo, por crerem que, havendo o crescimento, as relações contratuais de seguro estariam bem resolvidas.

Isso é falso. A conflituosidade está bastante aflorada, como todos os que militam no setor têm percebido: 'a judicialização da atividade seguradora está crescendo'.

Um Estado não é forte, nem mesmo se justifica, porque seus empresários faturam fortunas; ele só se justifica, e só será saudável, se cada um do povo for realmente protegido por suas instituições. Enquanto os seguros de crédito forem mascarados de seguro de vida (art. 104), enquanto os seguros dos cidadãos custarem nababescos carregamentos artificiais, algumas vezes mais de 90\% dos valores do prêmio (art. 58, XII); equanto setores da sociedade, da indústria e do comércio forem excluídos (art. 50, $\S 6^{\circ}$ ), por mais que sejam as arrecadações de prêmio e por mais solventes

decorrentes do princípio da autonomia privada. Quem não desejou contratar e, portanto, nãos e obrigou, não pode ser atingido por contrato realizado por terceiro."

${ }^{221}$ CARDOZO, José Eduardo Martins. O Resseguro na Lei do Contrato de Seguro - Constitucionalidade. Revista Brasileira de Direito do Seguro e da Responsabilidade Civil. Vol. 1, n. 2. São Paulo: MP, Dezembro2009, p. 129-135; CARDOZO, José Eduardo Martins. Disposições transitórias: Projeto de Lei $n$. 3.555/2004. IV Fórum de Direito do Seguro José Sollero Filho. 2006, p.597-605. 
que seja nossos seguradores, o país não estará no caminho preconizado pela Constituição Federal: o da democracia social e econômica e do desenvolvimento. ${ }^{222}$

\subsection{Seguro, soberania e solidariedade}

A questão que se coloca para a sociedade e, logicamente, para o Direito, não é apenas a da simples proteção dos direitos subjetivos individuais, mas a própria afirmação de soberania para o estabelecimento de uma ordem que proteja os cidadãos contra as tendências do capital e da tecnocracia capturada, o que em alguns casos demanda até mesmo a cooperação internacional, como lembra Benjamin R. BARBER:

Precisamos da soberania democrática para moderar a anarquia e o monopólio de mercado. Mas a soberania já não é viável de modo isolado dentro das nações. Paradoxalmente, como seus defensores mais entusiasmados reconhecem, o próprio capitalismo requer essa moderação para ele próprio florescer. Mas, considerando a realidade do etos cultural aqui retratado, moderar o capitalismo e renovar o chamado cívico são tarefas enormes, principalmente porque terão de ser realizadas tanto global como domesticamente. ${ }^{223}$

Essa também a reflexão de COMTE-SPONVILLE, para quem

[a] verdadeira questão não é ser a favor ou contra a mundialização; é saber que tipo de mundialização queremos. Uma mundialização ultra liberal, que retiraria todo o poder dos Estados? Uma mundialização coletivista, com a qual alguns continuam a sonhar? Ou uma mundialização regulada, controlada, acompanhada, o que supõe instâncias internacionais de decisão e de controle? ${ }^{224}$

Essa interação internacional para a contenção de políticas que desafiam as ordens públicas econômicas nacionais, por certo, deve ocorrer de forma que não se aprofundem ainda mais as exclusões, o que há de sempre merecer maior atenção no campo do seguro, onde já é conatural a dependência do resseguro internacional, com redobrada ênfase em países subdesenvolvidos como o Brasil. ${ }^{225}$ Afinal, aqui estamos diante da mais importante técnica de socialização das responsabilidades e intensifica-se, por isso, o seguinte questionamento de François EWALD: “A questão à qual somos confrontados poderia ser

\footnotetext{
${ }^{222}$ INSTITUTO BRASILEIRO DE DIREITO DO SEGURO. Contrato de seguro: uma Lei para todos. São Paulo: Quartier Latin, 2013.

${ }^{223}$ BARBER, Benjamin R. Consumidor - Como o mercado corrompe crianças, infantiliza adultos e engole cidadãos. Rio de Janeiro: Record, 2009, p. 376.

${ }^{224}$ Op. cit., p. 182 e ss.

${ }^{225}$ Ver nota 208 contendo matéria jornalística a respeito do IRB e suas interações com o resseguro internacional.
} 
assim formulada: sabendo que o processo de transformação social que agita nossas sociedades desde há dois séculos pode acolher políticas do pior, em quais condições pode ele conduzir ao melhor?"226

As melhores respostas estão situadas na ordem do comunitário, no campo do direito da solidariedade, na compreensão de que somos todos unidos pelo acidente e interessados no enfrentamento de suas consequências, individualmente impotentes, ao fim e ao cabo. E como de anteparos vêm soluções como a preconizada por Eros GRAU, citando não por mera coincidência os seguros, o deitar-se por terra "em nome da realização de justiça social - mas também do desenvolvimento - o princípio da liberdade de contratar" ${ }^{\text {} 227}$.

Tais respostas, contudo, como vimos, não obstante o esforço dos nossos juristas para a criação de um direito civil constitucional ou da potencialização do sentido da função social no sistema, confrontam na seara jurídica, e em quaisquer outros espaços, com a tradição individualista e a tendência à internalização solitária do exógeno social, de forma que as emanações dos profissionais em geral, mesmo os mais atentos, incluído aí de forma muito destacada os juristas, tendem para a obnubilação da dimensão social dos fenômenos, como já expusemos e também salienta COMTE-SPONVILLE:

Toda vez, ou quase, diante de problemas que são coletivos, sociais, conflituais - logo, políticos -, a tendência é, nas duas últimas décadas, dar apenas respostas individuais, morais, para não dizer às vezes sentimentais, claro que perfeitamente respeitáveis em sua ordem, mas, como é óbvio, igualmente incapazes de resolver e, no fundo, até de colocar esses problemas sociais, conflituais, políticos com que nos confrontamos. ${ }^{228}$

Hoje em dia, quando perguntamos às pessoas sobre seus seguros de automóvel "com perfil" - essa modalidade moldada em função dos anseios empresariais de lucro no lugar do tradicional seguro automobilístico - e ponderamos que elas estão pagando um pouco menos do que pagavam antes da entrada dos seguros "com perfil" no mercado, mas em contrapartida estão deixando a sociedade como um todo desprotegida e, em largo prazo, legitimando uma política de exclusão que não é assimilada em diversos outros países. O mais provável é escutarmos que não interessam os efeitos para a sociedade, pois não se pode ficar fazendo generosidade com os seguros próprios. Enquanto isso, a seguradora faz sua publicidade dizendo que "o seguro perfil feito exclusivamente

\footnotetext{
${ }^{226}$ EWALD, François. L'Etát Providence. Introdução - final. Paris: Grasset, 1986.

${ }^{227}$ GRAU, Eros Roberto. Elementos de Direito Econômico, São Paulo, Revista dos Tribunais, 1981, p. 17981.

${ }^{228}$ Op. cit., p. 23-4.
} 
para cada um dos seus clientes", um enganoso "a Cesar o que é de Cesar" que convence os consumidores a abandonarem os seguros tradicionais, "sem perfil".

O que falta ser compreendido, como adverte COMTE-SPONVILLE é que a generosidade

[é] diferente da solidariedade, que consiste em levar em conta os interesses do outro porque você compartilha esses interesses. Você faz um benefício a ele, e isso lhe traz ao mesmo tempo um benefício. (...) Quanta generosidade! (...) Ora, que eu saiba ninguém contrata uma apólice de seguro por generosidade: todos nós o fazemos por interesse. Mas essa cotização para cobrir os riscos, que é um seguro, permite-nos criar uma convergência objetiva de interesses entre os diversos segurados, em outras palavras, pelo menos uma solidariedade objetiva. É assim que nós nos protegemos - ao mesmo tempo todos juntos e cada um por si - contra as vicissitudes da existência. É o princípio do seguro: compartilhamento dos riscos, adição dos meios, convergência dos interesses, solidariedade. O que cada um faz para si faz também, quer queira, quer não, para os outros; o que faz para os outros, os outros também fazem por ele. Não é preciso ser generoso para tanto: o seguro é um negócio; o que equivale a dizer que funciona na base do egoísmo. É sem dúvida por isso que funciona tão bem. ${ }^{229}$

A superação das lesões causadas pelo convívio social não pode prescindir dessa solidariedade tecida com fios de necessidade e de egoísmo, mais do que animada pelo amor ao próximo. A tarefa que se impõe é a de estabelecer uma nova forma de julgamento, aquele que se atém à regra fundamental da repartição social:

O acidente moderno é contemporâneo das sociedades de massa e seu tipo de promiscuidade. Isto é evidente para os acidentes de trânsito: pode-se atribuí-los a falhas ou a erros pessoais; sabe-se, aliás, que a sua probabilidade aumenta com a circulação, o estado das estradas, etc. No limite, poder-se-ia dizer que, em certas condições de circulação, o acidente, longe de ser exceção, tende a tornar-se a regra; e que aquilo que é excepcional é não haver acidentes ou mais acidentes. ${ }^{230}$

Essa função, a de socializar a resposta dos indivíduos perante o acidente, única forma de enfrentar ou atenuar seus efeitos, mais do que uma utopia é precisamente a função securitária. E ela não se restringe ao campo da previdência (riscos aferidos, constatados - estatística), mas extravasa para a precaução (riscos suspeitados), pois o objeto do seguro, em que se "garante interesse legítimo contra riscos predeterminados" (art. 757 do CCB), pode-se constituir dos riscos da prevenção e da precaução.

\footnotetext{
${ }^{229}$ Op. cit., p. 122 e ss.

${ }^{230}$ EWALD, L'État Providence, op. cit.
} 
Essa amplitude da função protetiva da sociedade, mais recentemente posta na ordem das preocupações jurídicas em geral, já é antiga no campo securitário. ${ }^{231}$ Fazê-la fluir, contudo, não poderá depender dos governantes, quanto mais dos empreendedores dos seguros, sejam públicos sejam privados, como dá mostra a matéria jornalística antes referida em que um presidente do IRB, o que de mais importante o pais já teve em termos de promoção da função securitária e de sua democratização, declara que

[o]utros riscos poderão ser aceitos, porém serão olhados com lupa. É o caso dos seguros de responsabilidade civil, um ramo de pouca tradição no Brasil. Nesse caso, o IRB poderá entrar para ficar com uma pequena fatia, apenas para acompanhar o setor, obter informações para formar um banco de dados. "Mas desde que tenha cláusulas muito claras de exclusão de determinados riscos", avisa. ${ }^{232}$

Abra-se um parêntese para recordar que se, de um lado, ainda é ultraindividualista o ângulo pelo o qual é encarada a responsabilidade civil no meio judicial, de outro, o seguro dessa responsabilidade civil é reconhecido como instrumento capaz de promover a solidarização social, como ressalta Anderson SCHREIBER, o que, no entanto, será mais do que nunca freado pela lupa do underwriter estatal brasileiro ${ }^{233}$ :

Tem-se, em síntese, de reconhecer que a construção da responsabilidade social mostra-se, hoje, como um caminho a ser trilhado. No Brasil, embora as cortes judiciais tenham acelerado o processo de solidarização com relação aos pressupostos tradicionais da reparação, as decisões continuam necessariamente vinculadas à resposta individual que lhes reserva o ordenamento jurídico. A superação desta incoerência flagrante exige uma revisão critica da função da responsabilidade civil, que só mais recentemente vem-se propondo. As soluções securitárias, relativamente bem-sucedidas em outras experiências, devem ser estudadas com afinco, procedendo-se às necessárias adaptações do instituto à realidade dos países latino-americanos. ${ }^{234}$

\subsection{Intervenção estatal e constituição econômica}

A Constituição Federal contém o conjunto de princípios e regras essenciais ordenadoras da economia justamente por causa da impossibilidade de contarmos com a moral ou a ética vindas de forma espontânea da economia. Não se trata de um julgamento moral, mas do encaramento da realidade histórica, como registra Eros GRAU:

${ }^{231}$ M. MAYAUX, LUC. "Réflexions sur le principe de précaution et le droit des assurances" in Revue genérale du droit des assurances, $\mathrm{n}^{\circ} 2$. Paris L.G.D.J., 2003, p. 269-86.

${ }^{232}$ ROCHA, Janes. IRB quer risco rentável. Valor Econômico - 08 de dezembro de 2009.

${ }^{233}$ Idem anterior.

234 SCHREIBER, Anderson. Novos paradigmas da responsabilidade civil - Da erosão dos filtros da reparação à diluição dos danos, 2a ed., São Paulo, Atlas,2009, p. 237. 
As imperfeições do liberalismo, no entanto, associada à incapacidade de auto-regulação dos mercados, conduziram à atribuição de nova função ao Estado. À idealização de liberdade, igualdade e fraternidade se contrapôs a realidade do poder econômico. ${ }^{235}$

Entre outros, um dos papéis do Estado é o de regular a economia:

Evidente a inviabilidade do capitalismo liberal, o Estado, cuja penetração na esfera econômica já se manifestara na instituição do monopólio estatal da emissão da moeda - poder emissor -, na consagração do poder de polícia e, após, nas codificações, bem assim na ampliação do escopo dos serviços públicos, assume o papel de agente regulador da economia. ${ }^{236}$,

Mas, o Estado atuará - ou ao menos deveria - segundo os princípios e regras conformadores de da ordem econômica juridicamente projetada através da chamada constituição econômica: "conjunto de princípios que institui determinada ordem econômica (mundo do ser) ou conjunto de princípios e regras essenciais ordenadoras da economia, é de se esperar que, como tal, opere a consagração de um determinado sistema econômico." 237

Cabe verificar que os objetivos da República são consignados na Constituição Federal de 1988 por meio de comandos democratizadores do "mercado interno, que integra o patrimônio nacional" (CF, art. 219) $)^{238}$, e que buscam um projeto de desenvolvimento, ao mesmo tempo, internalizador dos centros de decisão $\left(\mathrm{CF}\right.$, art. $3^{\circ}$, caput) e redutor das desigualdades sociais $\left(\mathrm{CF}, \text { art. } 3^{\circ} \text {, incisos }\right)^{239}$

A constituição econômica existe para que se garanta a construção de uma "sociedade livre, justa e solidária" (art. $\left.3^{\circ}, \mathrm{I}\right)$ e, para tanto, estabelece no art. 170, entre outros, os princípios que se coordenam com os "objetivos da República" (art. $3^{\circ}$ e incisos), a soberania nacional, a função social da propriedade, a livre concorrência, a defesa do consumidor, a defesa do meio ambiente, a redução das desigualdades regionais e sociais, a

${ }^{235}$ GRAU, Eros Roberto. A Ordem Econômica na Constituição de 1988, $9^{\text {a }}$ ed. São Paulo, Malheiros, 2004, p. 17.

${ }^{236}$ GRAU. op. Cit. p. 21

${ }^{237}$ Idem anterior, p. 72.

${ }^{238}$ Art. 219 . O mercado interno integra o patrimônio nacional e será incentivado de modo a viabilizar o desenvolvimento cultural e sócio-econômico, o bem-estar da população e a autonomia tecnológica do País, nos termos de lei federal.

${ }^{239}$ Art. $3^{\circ}$ Constituem objetivos fundamentais da República Federativa do Brasil:

I - construir uma sociedade livre, justa e solidária;

II - garantir o desenvolvimento nacional;

III - erradicar a pobreza e a marginalização e reduzir as desigualdades sociais e regionais;

IV - promover o bem de todos, sem preconceitos de origem, raça, sexo, cor, idade e quaisquer outras formas de discriminação. 
busca do pleno emprego e o tratamento favorecido para as empresas de pequeno porte constituídas sob as leis brasileiras e que tenham sua sede e administração no País. ${ }^{240}$

Esse passeio pela Constituição Federal já é o bastante para dar conta de que lesões à ordem econômica constituem inconstitucionalidades e, portanto, será inconstitucional a regulação dos contratos (por norma ou decisão) que verter em sentido contrário a ela.

Para ainda mais equipar o Estado brasileiro com o objetivo de garantir a consecução da ordem econômica constitucional, foi editada a Lei n. 8.884, de 11 de junho de 1994, que transformou o Conselho Administrativo de Defesa Econômica (CADE) em autarquia e dispôs sobre a prevenção e a repressão às infrações contra a ordem econômica. Com o fim de tutelar bens jurídicos da comunidade, versou sobre a prevenção e a repressão às infrações contra a ordem econômica, orientada pelos ditames constitucionais de liberdade de iniciativa, livre concorrência, função social da propriedade, defesa dos consumidores e repressão ao abuso do poder econômico." (art. $1^{\circ}$ e par. único). Essa lei aplicava-se a "pessoas físicas ou jurídicas de direito público ou privado (...), ainda que temporariamente, com ou sem personalidade jurídica, mesmo que exerçam atividade sob regime de monopólio legal" (art. 15) e os tipos nela previstos previa implicarem "a responsabilidade da empresa e a responsabilidade individual de seus dirigentes ou administradores, solidariamente" (art. 16), solidariedade essa que se estendia às empresas ou entidades integrantes de grupo econômico, de fato ou de direito, que praticarem infração da ordem econômica (art. 17), sendo ainda passível de desconsideração a personalidade jurídica do responsável por infração da ordem econômica, quando houver da parte deste abuso de direito, excesso de poder, infração da lei, fato ou ato ilícito ou violação dos estatutos ou contrato social, bem como houver falência, estado de insolvência,

\footnotetext{
${ }^{240}$ Art. 170. A ordem econômica, fundada na valorização do trabalho humano e na livre iniciativa, tem por fim assegurar a todos existência digna, conforme os ditames da justiça social, observados os seguintes princípios:

I - soberania nacional;

II - propriedade privada;

III - função social da propriedade;

IV - livre concorrência;

$\mathrm{V}$ - defesa do consumidor;

VI - defesa do meio ambiente, inclusive e diante tratamento diferenciado conforme o impacto ambiental dos produtos e serviço se de seus processos de elaboração e prestação;

VII - redução das desigualdades regionais e sociais;

VIII - busca do pleno emprego;

IX - tratamento favorecido para as empresas de pequeno porte constituídas sob as leis brasileiras e que tenham sua sede e administração no País.
} 
encerramento ou inatividade da pessoa jurídica provocados por má administração (art., $18) .^{241}$

Em seu art. 20 a Lei de prevenção e repressão ao abuso contra a ordem econômica definia as infrações de que se ocupava, valendo notar ser indiferente o viés subjetivo que as deflagrou. $^{242}$

Nesse contexto, para a construção de uma sociedade "justa e solidária", para fortalecer o mercado interno, cumprir os objetivos da república e atuar segundo os princípios constitucionais, o Estado Brasileiro, como visto, criou um órgão voltado para a defesa da ordem econômica securitária, o denominado Sistema Nacional de Seguros Privados, nele colocando a sociedade de economia mista IRB como como órgão regulador do resseguro, co-seguro e retrocessões e como sociedade monopolista do resseguro, como se vê do Decreto-lei n. 73, de 21 de novembro de 1966, especialmente no art. $44^{243}$.

O mesmo decreto ainda dispõe que o controle confiado aos órgãos estatais deve ser feito no interesse dos consumidores, "segurados e beneficiários" (art. $2^{\circ}$ ), cumprindo ao

${ }^{241}$ Posteriormente, foi revogada pela Lei n. 12.529, de 30 de novembro de 2011, a qual mantém o regime da lei revogada no tocante ao que aqui é relevante.

${ }^{242}$ Art. 20. Constituem infração da ordem econômica, independentemente de culpa, os atos sob qualquer forma manifestados, que tenham por objeto ou possam produzir os seguintes efeitos, ainda que não sejam alcançados:

I - limitar, falsear ou de qualquer forma prejudicar a livre concorrência ou a livre iniciativa;

II - dominar mercado relevante de bens ou serviços;

III - aumentar arbitrariamente os lucros;

IV - exercer de forma abusiva posição dominante."

Ver a especificação no artigo seguinte: "Art. 21. As seguintes condutas, além de outras, na medida em que configurem hipótese prevista no art. 20 e seus incisos, caracterizam infração da ordem econômica;

I - fixar ou praticar, em acordo com concorrente, sob qualquer forma, preços e condições de venda de bens ou de prestação de serviços;

II - obter ou influenciar a adoção de conduta comercial uniforme ou concertada entre concorrentes; (...)

$\mathrm{V}$ - criar dificuldades à constituição, ao funcionamento ou ao desenvolvimento de empresa concorrente ou de fornecedor, adquirente ou financiador de bens ou serviços; (...)

$\mathrm{X}$ - regular mercados de bens ou serviços, estabelecendo acordos para limitar ou controlar a pesquisa e o desenvolvimento tecnológico, a produção de bens ou prestação de serviços, ou para dificultar investimentos destinados à produção de bens ou serviços ou à sua distribuição; (...)

XII - discriminar adquirentes ou fornecedores de bens ou serviços por meio da fixação diferenciada de preços, ou de condições operacionais de venda ou prestação de serviços;

${ }^{243}$ Art. 44. Compete ao IRB:

I - Na qualidade de órgão regulador de cosseguro, resseguro e retrocessão:

a) elaborar e expedir normas reguladoras de cosseguro, resseguro e retrocessão;

b) aceitar o resseguro obrigatório e facultativo, do País ou do exterior;

c) reter o resseguro aceito, na totalidade ou em parte;

d) promover a colocação, no exterior, de seguro cuja aceitação não convenha aos interesses do País ou que nele não encontre cobertura; (...)

g) proceder à liquidação de sinistros de conformidade com os critérios traçados pelas normas de cada ramo de seguro;

h) distribuir pelas sociedades a parte dos resseguros que não retiver e colocar no exterior as responsabilidades excedentes da capacidade de mercado segurador interno, ou aquelas cuja cobertura fora do País convenha aos interesses nacionais; $(\ldots)$

j) promover o pleno aproveitamento da capacidade do mercado nacional de seguros. 
resseguro, ao cosseguro e à retrocessão a tarefa de pulverizar os riscos e fortalecer as relações de mercado (art. $4^{\circ}$ ), este submetido a uma política voltada para a expansão dos serviços securitários e sua integração no processo econômico e social do país (art. $5^{\circ}$ ). ${ }^{244}$

Justamente prevenindo o estabelecimento de políticas de discriminação quando do desenvolvimento dos negócios securitários, o legislador retirou das seguradoras o direito de conceder benefícios diferenciados entre os seus clientes, dispondo seu art. 30 que "[a]s Sociedades Seguradoras não poderão conceder aos segurados comissões ou bonificações de qualquer espécie, nem vantagens especiais que importem dispensa ou redução de prêmio".

Aproximando o foco para os objetivos deste estudo, observamos que mesmo para além da autarquia federal fiscalizadora, a Superintendência de Seguros Privados - SUSEP - que notabilizou-se durante muito tempo por assumir de fato, e com extravagâncias inconstitucionais, as funções de outro órgão, o quase inanimado Conselho Nacional de Seguros Privados - CNSP -, o IRB foi destinatário de grande ênfase sendo um caso raro, senão único, de sociedade de economia mista (art. 41) cujo presidente e vice-presidente eram nomeados pelo próprio Presidente da República. ${ }^{245}$

Em parecer atinente às funções do IRB, antes e depois de viger a Lei Complementar n. 126/2007 que extinguiu o monopólio do resseguro e transportou a competência de regulação sobre as relações de resseguro do IRB para a SUSEP, BERCOVICI cuida da relevância da função cometida pelo Estado Brasileiro ao IRB para a ordem econômica do país:

Deste modo, a importância do antigo monopólio legal do IRB e do controle estatal sobre a política de seguros privados justificava-se (e, em certa medida, ainda se justifica) para garantir o interesse dos segurados e beneficiários dos contratos de seguro, fortalecer as relações econômicas do mercado e para promover a expansão e integração do mercado de seguros no processo econômico e social do país, evitar a evasão de divisas, preservar a liquidez e solvência das seguradoras e coordenar a

\footnotetext{
244 Art. $2^{\circ} \mathrm{O}$ controle do Estado se exercerá pelos órgãos instituídos neste Decreto-lei, no interesse dos segurados e beneficiários dos contratos de seguro.

Art. $4^{\circ}$ Integra-se nas operações de seguros privados o sistema de cosseguro, resseguro e retrocessão, por forma a pulverizar os riscos e fortalecer as relações econômicas do mercado.

Art. $5^{\circ}$ A política de seguros privados objetivará: I - Promover a expansão do mercado de seguros e propiciar condições operacionais necessárias para sua integração no processo econômico e social do País;

245 Art. 46 (...) $\S 2^{\circ}$ A Diretoria do IRB é composta por seis membros, sendo o Presidente e o VicePresidente Executivo nomeados pelo Presidente da República, por indicação do Ministro de Estado da Fazenda, e os demais eleitos pelo Conselho, de Administração.
} 
política de seguros com as políticas de investimentos, monetária, creditícia e fiscal do Governo Federal. ${ }^{246}$

Comenta BERCOVICI, ainda, a subsunção da atividade do IRB à tipologia das infrações contra a ordem pública econômica:

Como a atividade de resseguro é uma atividade econômica de relevante interesse coletivo, tem-se que a Lei n. 8.884/1994 se aplica às condutas do IRB que violem as regras concorrenciais, mesmo tendo sido o IRB monopolista por força de lei, por se tratar da prestação de uma atividade econômica em sentido estrito (o resseguro), e não de um serviço público. Tal atividade econômica em sentido estrito, conforme destacado anteriormente, é de relevante interesse coletivo, possuindo a função de implementar uma política pública específica. Se, por um lado, não é serviço público, de outro, está adstrita a deveres e condutas explícitos e específicos, que tornam o regime de direito administrativo e de direito concorrencial fundamentos rigorosos de sua implantação. E, justamente, uma das tarefas do direito econômico é a de controlar o comportamento dos poderes econômicos. ${ }^{247}$

\subsection{Seguro e captura institucional}

Em declaração do dia 8 de dezembro de $2009^{248}$, o representante do IRB comemorava que a sociedade de economia mista resseguradora se encontrava numa em nova fase. Agiria com agressividade para recuperar o tempo perdido e através de politica de subscrição feita com lupa fugirá dos seguros de responsabilidade civil.

Éramos também surpreendidos, ao navegar pelo site do IRB e consultar o que ali existia a respeito do seguro de responsabilidade civil de administradores e conselheiros de sociedades, mais conhecido pelo seu nome anglo-saxão "Directors \& Officers" ou, simplesmente, "D\&O”. Examinando as condições de seguro estampadas como padrão para o mercado brasileiro, no canto inferior esquerdo da tela distinguia-se "AIU D\&O - IRB Brasil RE/Review 01/04”. No documento eletrônico, via-se que, em janeiro de 2004, o IRB fora capturado pela American International Underwriters, uma seguradora e resseguradora norte-americana do AIG - American International Group, associado à época com a

\footnotetext{
${ }^{246}$ BERCOVICI, Gilberto. IRB - Brasil Resseguros S.A. Sociedade de Economia Mista. Monopólio de Fato, Dever de Contratar e Proteção à Ordem Pública Econômica. RDE. Revista de Direito do Estado, v. 12, 2008, p. 27.

${ }^{247}$ Idem.

${ }^{248}$ Ver matéria jornalística preproduzida na nota 315.
} 
Unibanco Seguradora S.A., uma das acionistas do então órgão ressegurador oficial monopolista. ${ }^{249}$

$\mathrm{Na}$ época coexistiam diferentes clausulados, como é próprio da concorrência no setor, mas o IRB foi capturado pela AIU/AIG que impôs o seu "Business Guard 08/03/Civil Law Countries".

A automaticidade com que são feitas as capturas nos etor de seguro não comportam caprichos. A péssima elaboração da tradução utilizada dá clara mostra do desrespeito aos consumidores de seguros brasileiros:

As partes declaram que participaram ativamente da preparação deste contrato e que não há nenhum tipo de vício ou erro em sua elaboração que possa afetar a nulidade do mesmo. - IRB Brasil RE/Review 01/04 (p. 03-18).

Entre tantas teratologias, o documento que a AIG-Unibanco impôs no IRB em 1994, e que se transformou em padrão para o mercado monopolizado, em detrimento dos contratantes do seguro e das seguradoras que concorriam com clausulados diferentes e até mesmo reconhecidamente melhores, como era o caso da CHUBB, ignorava o disposto no artigo 787 do Código Civil brasileiro, que esclarece que o seguro de responsabilidade é destinado a garantir o pagamento devido à vítima, pois permitia que todo o valor segurado fosse consumido para pagar exclusivamente os honorários e despesas com o custo de defesa, esvaziando a função do seguro de responsabilidade civil expressa na lei e impondonos um padrão de seguro estadunidense. ${ }^{250}$

A consecução da ordem econômica, requer, nesse jogo de captura e omissão, o constante aperfeiçoamento do sistema legislativo, formando-se um guia o mais preciso possível para evitar que as operações práticas de aplicação do direito (regulamentações, decisões, pareceres) desgarrem para atuar no sentido inverso daquele que se planificou na Constituição Econômica.

Embora tanto o IRB e a SUSEP devessem promover o atendimento ao art. 787 do Código Civil, também a SUSEP aquiescia com o desvio, ao manter vigente, sem ressalva alguma, sua Circular n. 57, de 04 de novembro de 1981, em que estabelecia, a propósito do

\footnotetext{
249 TZIRULNIK, Ernesto. "La póliza D\&O” in III Jornadas de Reaseguro, 2005. Memorias de las III Jornadas de Reaseguro. México, DF: Swiss Re, 2005.

${ }^{250}$ Art. 787. No seguro de responsabilidade civil, o segurador garante o pagamento de perdas e danos devidos pelo segurado a terceiro.
} 
limite de responsabilidade do seguro de responsabilidade civil que esta se esgotaria com a "soma das indenizações e despesas pagas".

A captura do IRB fora tão brutal que, nas Condições Gerais do D\&O, item 5.1.3., encontrava-se uma regra de tratamento privilegiado para clientes do grupo norteamericano:

A cobertura prevista por esta cláusula será somente uma cobertura adicional a todas essas indenizações e pagamentos dessa maneira obtidos e recuperados. Na hipótese de o referido seguro ter sido contratado junto à Seguradora ou qualquer empresa associada à AIU (ou tenha sido contratado para cobertura destinada especificamente a cobrir valores que excedam os limites de responsabilidade desta Apólice), o limite total agregado de responsabilidade por todas as indenizações cobertas em virtude da extensão de cobertura ora prevista nesta cláusula será reduzido na proporção do limite de responsabilidade especificado na apólice do outro seguro contratado pela Entidade Sem Fins Lucrativos junto à empresa da AIU.

O fato não é isolado. São tantos os casos que sucedem no âmago da SUSEP que a descaracterização ou a desnaturação dos contratos somente não acontece com plenitude porque as instituições solidamente criadas pelos homens, e tão necessárias como o seguro, tendem a sobreviver.

Antes de examinarmos o que se passou no âmbito dos seguros de riscos de engenharia ou construção, convém mais um exemplo do sucumbimento institucional brasileiro.

Imediatamente após o advento do chamado Plano Collor, com o objetivo de beneficiar as companhias seguradoras, permitindo-lhes desfazerem-se dos Cruzados Novos, a SUSEP expediu a Circular n. 6, de 2 de abril de 1990 , cujo $\S 1^{\circ}$ do art. $2^{\circ}$ dispunha:

\footnotetext{
Art. $2^{\circ}$. (..)

$\S 1^{\circ}$ Os sinistros ocorridos anteriormente a 16 de março de 1.990 , ainda pendentes de pagamento, poderão ser indenizados, a critério do segurador, mediante transferência de titularidade dos cruzados novos correspondentes ao segurado.
}

A regra permitiu que as companhias seguradoras extinguissem as dívidas de indenização por sinistros ocorridos até 16 de março de 1990 com a simples transferência da titularidade de Cruzados Novos aos segurados e beneficiários, contrariando frontalmente o art. $2^{\circ}$ do Decreto-lei n. 73/66, violando princípio fundamental dos seguros (princípio indenizatório), e também negando incidência para o art. 1.458 do CCB/1916, então vigente, que obrigava o pagamento da indenização em dinheiro: “[o] segurador é obrigado 
a pagar, em dinheiro, o prejuízo (...) e conforme as circunstâncias o valor total da coisa segura".

Os segurados, ao invés de receberem moeda com poder liberatório e, assim, verem-se aptos para a continuidade de seus negócios, repondo as mercadorias incendiadas ou a máquina que quebrou, recebiam das seguradoras um título da dívida pública, sem o necessário poder liberatório. ${ }^{251}$

${ }^{251}$ Nesse sentido, ver EJZENBERG, Wolf. "Fiscalização da atividade seguradora - Limites do controle estatal". Revista brasileira de Direito do Seguro e da Responsabilidade Civil. São Paulo, Ano I, n. 1, p. 311343, 2008. 


\section{Capítulo 4: Seguro de Riscos de ENGenharia}

\subsection{Histórico e características}

A responsabilidade pelos acidentes da engenharia é tema relevante desde a antiguidade. Cinco dispositivos do Código de Hamurabi (1760 AC) ${ }^{252}$ promovem as regras da arte de projetar e construir. ${ }^{253}$

Alguns autores identificam nesse mesmo Código do "estágio inicial do desenvolvimento das necessidades sociais" o princípio geral securitário de distribuição das perdas ou pulverização dos riscos. Isto porque a regra n. 22 prevê que aquele que for flagrado roubando será condenado à morte, enquanto que a seguinte regra (n. 23) dispõe que na hipótese de o agente não ser capturado, a vítima deve solenemente declarar o que lhe foi subtraído - é diversa a fidúcia dada à vítima do quanto usam creditar-lhe os

\footnotetext{
252“"As cinco regras relacionadas com a engenharia de construções civis são as seguintes:

§229. Se um engenheiro construiu uma casa para um senhor, mas não deu solidez à obra e a casa que construiu desabou e causou a morte do proprietário da casa, o engenheiro receberá a morte.

$\S 230$. Se é o filho do proprietário da casa quem morre, receberá a morte o filho do engenheiro.

$\S 231$. Se é o escravo do proprietário da casa quem morre, dará ao proprietário da casa um escravo pelo escravo.

$\S 232$. Se destruiu objetos, tudo o que tenha destruído, pagará. E posto que não deu solidez à casa que edificou e desabou, reconstruirá às suas expensas a casa que desabou.

$\S 233$. Se um engenheiro construiu uma casa para um senhor e não executou seu trabalho seguindo as normas e um muro inclinou, esse engenheiro às suas próprias expensas reformará o muro."

Original: "\$229. Si un albañil ha edificado una casa para un señor, pero no ha dado solidez a la obra y la casa que construyó se ha desplomado y ha causado la muerte del propietario de la casa, ese albañil recibirá la muerte; §230. Si es al hijo del propietario de la casa a quien ha causado la muerte, recibirá la muerte el hijo de ese albañil; §231. Si es al esclavo del propietario de la casa a quien ha causado la muerte, dará al propietario de la casa un esclavo por (el) esclavo; §232. Si ha destruido bienes, todo lo que haya destruido (lo) pagará. Y puesto que no dio solidez a la casa que edificó y se desplomó, (re)construirá a sus propias expensas la casa que desplomó; §233. Si un albañil ha edificado una casa para un señor y no ha ejecutado su trabajo siguiendo las normas y un muro se ha inclinado, ese albañil a sus propias expensas reforzará el muro."

Além dessas disposições relativas às construções civis, o Código também traz uma disposição atinente à responsabilidade do construtor naval: "\$235. Se um barqueiro calafetou uma embarcação para um senhor, mas não assegurou seu trabalho e nesse mesmo ano a embarcação inclina ou manifesta algum defeito, ele assumirá a culpa; o barqueiro desmontará essa embarcação e a reforçará às suas próprias expensas; (depois) devolverá a embarcação reforçada ao proprietário da embarcação". Original: "§ 235. Si un barquero ha calafateado una embarcación para un señor, pero no ha asegurado su obra y (si) en ese mismo año esa embarcación escora, o manifiesta algún defecto, él asumirá la culpa; el barquero desmontará esa embarcación y la reforzará a sus propias expensas; (después) devolverá la embarcación reforzada al propietario de la embarcación". Código de Hammurabi. Tradução espanhola de Federico Lara Peinado, 4a . ed. Madri: Tecnos, 2008 , p. 14.

253 BUNNI, Nael G. Risk and Insurance in Construction. $2^{\mathrm{a}}$ ed. Oxon: Spon Press, 2003, p. 1-3.
} 
seguradores atuais - e a cidade e governantes deverão restituir-lhe integralmente os bens perdidos. $^{254}$

BUNNI vê nesses dispositivos, somados às regras atinentes aos riscos que um investidor assume em troca de parte dos lucros de uma viagem, o princípio da partilha de prejuízos (loss-sharing):

Assim, os babilônios naquele tempo sabiam como partilhar perdas por meio de certos costumes comerciais, o que hoje chamamos 'bodemeria'. É um termo usado para descrever um contrato marítimo segundo o qual o dono de uma embarcação toma dinheiro emprestado por um período específico de tempo para financiar uma viagem, dando como garantia a própria embarcação. (...) Portanto, poderia ser dito que, com os dois conjuntos de regras codificadas acima, Hammurabi deu início a todo o processo de gerenciamento de risco. Os riscos de acidentes, perdas e danos nos contratos de construção foram identificados e distribuídos entre as partes contratantes. Os riscos comerciais e os riscos de construção e posse de uma propriedade também foram identificados e distribuídos segundo uma base lógica que permanece conosco até o dia de hoje.

Os programas concentrados de reconstrução em áreas devastadas do mundo, acompanhados pelos rápidos avanços tecnológicos que ocorreram com novos materiais e métodos de construção, consolidaram os princípios de risco, responsabilidade, compromisso e indenização na área que deu origem, de um modo ou de outro, a uma forte necessidade de seguro de construção. . ${ }^{255}$

De todo modo, o seguro contemporâneo, técnico, surge bem depois do entre rios, por volta do século XV com o desenvolvimento do comércio marítimo. Em 1601, o Parlamento inglês edita uma lei de seguro (Insurance Act) definindo o seguro a partir de três objetivos que seguem atuais: distribuir as perdas de alguns entre muitos, encorajar aqueles que são reticentes para assumir riscos antes da garantia de uma compensação e convocar os mais jovens a serem empreendedores, assim se descortinando, o seguro, enfim

254 “\$22. Se um senhor se entrega à bandidagem e chega a ser preso, esse senhor receberá a morte. §23. Se o bandido não é preso, o senhor (que tenha sido roubado) declarará oficialmente perante Deus (os pormenores de) o que perdeu; depois, a cidade e o governador em cujo território e jurisdição se cometeu a bandidagem, lhe compensará (por todo) o perdido". Original: “\$22. Si un señor se entrega al bandidaje y llega a ser prendido, ese señor recibirá la muerte. \$23. Si el bandido no es prendido, el señor (que ha sido robado) declarará oficialmente delante del dios (los pormenores de) lo perdido; después, la ciudad y el gobernador en cuyo territorio y jurisdicción se cometió el bandidaje, le compensarán (por todo) lo perdido." Código de Hammurabi, op. cit., p. 10.

255 BUNNI, Nael G. Risk and Insurance in Construction, op. cit., p. 3. Original em inglês: "Thus, the Babylonians knew at that time the loss-sharing principle through trading customs in what is referred to today as 'bottomry' in the English language. It is a term given to describe a maritime contract, under which a vessel owner borrowed money for a specific period of time to finance a voyage, on the security of the vessel. (...) Therefore, it could be said that with the above two sets of codified rules, Hammurabi started the whole process of risk management. The risks of injury, loss and damage in construction contracts were identified and allocated between the contracting parties. The commercial risks and the risks of building and owning property were also identified and allocated on a logical basis that remains with us till this day." 
como uma técnica de pulverização do risco ou distribuição comunitária do custos dos acidentes para evitar as perdas individuais e promover as ações empreendedoras. ${ }^{256}$

À margem do discurso moralista que costuma impregnar páginas de livros técnicos e jurídicos sobre o tema seguro, é interessante notar que, atualmente, os seguradores, ainda que estimulados por razões comerciais, seguem voluntariamente assumindo riscos intensificados pela ousadia econômica. A realidade da vida econômica impõe a postura. Num mundo financeirizado, todas as áreas da atividade econômica e da vida social vêm exigindo radical redução de custos para aumento de margens e, com isso, decai a qualidade dos riscos que lhes são inerentes, o que é obstado pelo avanço tecnológico, igualmente comprometido com a produção de resultados financeiros. É muito interessante, a respeito, a pesquisa de ERICSON, DOYLE e BARRY:

Em condições favoráveis de subscrição de riscos, as seguradoras trabalham com seus clientes comerciais numa relação que visa primordialmente adequar e melhorar o ambiente de prevenção de perdas. Entrevistamos um especialista do serviço técnico de prevenção de perdas de uma seguradora comercial multinacional. Ele tinha uma equipe de engenheiros de controle de perdas que inspecionava propriedades comerciais na etapa de subscrição de riscos e fazia recomendações para melhorá-las. Ele disse: 'Podemos fazer o seguro mesmo que eles não sigam as recomendações. Trabalhamos com a subscrição o tempo todo e com a corretora para tentar motivar o cliente a seguir as recomendações'. Este entrevistado descreveu a subscrição de uma firma comercial que tinha um sistema inadequado de sprinklers para combater incêndios. Um sistema novo custaria US\$350.000 e a abordagem adotada foi instalar esse sistema ao longo de vários anos para diluir o custo. Se um sistema completamente novo fosse exigido logo no início como condição para fazer o seguro, o cliente poderia facilmente ter encontrado outra seguradora e teríamos perdido uma relação lucrativa de seguro. Além disso, a corretora de seguros envolvida também tinha uma relação importante com o cliente e com a seguradora, que poderia ser prejudicada se o cliente fosse pressionado além da conta em detalhes da prevenção de perdas. $\mathrm{O}$ entrevistado usou esse caso para ilustrar como uma situação inadequada de segurança preventiva pode ainda ser segurada 'porque faz sentido comercial oferecer a apólice, visto que estamos tentando crescer junto com essa corretora. Ou, este é um plano de seguro em vinte; os outros dezenove são impecáveis e trata-se potencialmente de $\$ 10$ milhões ou seja o que for, $\$ 12$ milhões em prêmios, e estou diposto a assumir um negócio ruim a fim de escrever os outros dezenove'. ${ }^{257}$

\footnotetext{
${ }^{256}$ BUNNI, Nael G. Risk and Insurance in Construction, op. cit., p. 4.

${ }^{257}$ Op. cit., p. 295. Original em inglês: "In soft market underwriting conditions, insurers work with their commercial clients in more of a compliance relationship to improve the loss prevention environment. We interviewed a loss prevention techinical service specialist for a multinational commercial insurer. He had a team of loss control engineers who inspected commercial properties at the underwriting stage and made recommendations for improvement. He said 'We may underwrite it without them complying with the recommendations. We work with underwriting all the time and the broker to try and help get the client motivated to comply with the recommendations.'
} 
Ao desenvolvimento do comércio marítimo, segue o dos seguros de vida e, especialmente após o grande incêndio de Londres de 1666, o do seguro incêndio. Os seguros relacionados com os demais acidentes florescem a partir do desenvolvimento tecnológico promovido pelo capitalismo industrial, a Revolução Industrial do século XIX. As máquinas a vapor estão nessa nova gênese securitária.

Os seguros de riscos relacionados à tecnologia remontam ao século XIX, às caldeiras inventadas e desenvolvidas por PAPIN (1690), NEWCOMEN (1725) e James WATT (1781). Os fabricantes de caldeiras organizaram-se como prestadores de serviços de manutenção e prevenção dos riscos envolvidos com a operação desses equipamentos fundamentais da indústria da época e logo se transformaram em seguradores de riscos industriais. Os fabricantes e usuários de caldeiras, ao que se conta liderados pelo depois cavaleiro William FAIRBAIRN, começaram a se reunir para discutir a infortunística das caldeiras e as soluções de engenharia, criando, depois, a associação de usuários de vapor de Manchester. Essa associação prestava serviços de inspeção de riscos e assistência técnica aos usuários das caldeiras. Como registra o curso de seguros de riscos de engenharia do Chartered Insurance Institute, nasce aí a primeira seguradora especializada:

(...) Se pensó que la inspección con seguro sería un paso importante hacia adelante y bastante atractivo para los industriales y usuarios de vapor. Como no todos los miembros de esa asociación estaban conformes con el seguro, varios de ellos fundaron en 1858 la primera compañía de seguros de ingeniaría, la Steam Boiler Assurance Company, a la que siguieran otras compañías similares. ${ }^{258}$

Dessa mesma obra destaca-se o seguinte:

16. El servicio de inspección es importante para las compañías de seguros, no solo porque la mayor parte del negocio de ingeniaría depende de ello, sino también porque toda la prevención de perdidas redunda en su propio interés, desde el punto de vista de las reclamaciones.

This interviewee described the underwriting of a commercial firm that had an inadequate sprinkler system. A new system would cost $\$ 350,000$, and the approach taken was to have a new system installed over several years to spread the cost. If a complete new system were demanded at the outset as a condition of underwriting, the client could easily have found another insurer and a profitable insurance relationship would have been lost. Moreover, the insurance broker involved also had an important relationship to both the client and the insurer which may have been lost in the client was presses too far on loss prevention details. The interviewee used this case to illustrate that an inadequate preventive security situation may still be underwritten 'because it makes good business sense to write it because we're trying to grow with this broker. Or, this is one insurance plan in twenty, the other nineteen are spotless and it's potentially $\$ 10$ million or whatever, $\$ 12$ million in premiums and I'm willing to take one bad one to write the other nineteen good ones."

258 CHARTERED INSURANCE INSTITUTE. Seguro de ingeniaría. $2^{a}$ edição. Tradução espanhola por Manuel Vivas Díaz-Berrio, Madri: Ed. Mapfre, 1979, p. 3. 
17. Algunas compañías de seguros cubren riesgos de maquinaria, sin establecer un servicio de inspección, pero únicamente de forma limitada. La maquinaria objeto de dichos seguros sin inspección (por ejemplo, motores eléctricos, maquinas y equipos mecánicos rotatorios) no está sujeta a requisitos legales de inspección. Otras compañías de seguros prefieren inspeccionar toda la instalación asegurada porque mediante una inspección periódica a cargo de ingenieros calificados se reduce el peligro de fallo. (...)

19. Las ventajas de un servicio de inspección completo en todas las instalaciones aseguradas son las siguientes:

a) Se reduce el riesgo de averías con los perjuicios subsiguientes y la posible perdida de producción.

b) Se benefician del asesoramiento del ingeniero inspector en materia de reparación, mantenimiento y renovación de la instalación. Se puede solicitar su ayuda en caso de dificultades o ineficacia de la instalación.

c) Se mantiene la seguridad. ${ }^{259}$

Os seguros relacionados à tecnologia, como se vê, surgem com a experiência industrial e conectados à ideia de prevenção, cumulando a garantia de seguro com a prestação de serviços, modelo que, embora não predominante, segue existindo até o presente. Um exemplo atual é a "The Boiler Inspection and Insurance Company of Canada”, companhia líder canadense no fornecimento de seguros e serviços técnicos de inspeção preventiva de acidentes. A companhia "é líder no fornecimento de subscrição especializada e habilidades técnicas exigidas para segurar equipamentos. A HSB BI\&I oferece soluções inovadoras contra risco que lhe mostram não se, mas como você pode permanecer à frente dos desafios emergentes no mundo complexo de hoje. ${ }^{, 260} \mathrm{O}$ interessante site da seguradora canadense confirma a origem e a função do seguro de riscos atinentes às tecnologias:

Embora as origens de nosso negócio datem da Era do Vapor, a necessidade básica permanece a mesma - as empresas são vulneráveis a danos e interrupções causados pelo colapso de equipamentos. No mundo complexo e altamente interconectado de hoje, com a nossa ampla dependência de sistemas de comunicação eletrônica, a potencial interrupção dos negócios devido a falhas de equipamento ou perda de dados pode ser ainda maior. Como o seguro convencional de propriedade não cobre essas perdas, a mitigação desses riscos mediante seguros de avaria de equipamento não é um item opcional 'desejável', mas uma ferramenta essencial de gestão. ${ }^{261}$

\footnotetext{
${ }^{259}$ CHARTERED INSURANCE INSTITUTE. Seguro de ingeniaría, op. cit. p. 5-6.

${ }^{260}$ Original do inglês: "has been the leader in providing the specialized underwriting and technical skills required for insuring equipment. HSB BI\&I offers innovative risk solutions that show you not if, but how you can stay ahead of emerging challenges in today's complex world."

261Disponível em <http://www.biico.com>. Acesso em 10 de dezembro de 2013. Original em inglês: "While the origins of our business date from the steam age, the basic need remains the same - businesses are vulnerable to damage and interruptions caused by equipment breakdown. In today's complex and highly interconnected world, with our extensive reliance on electronic communication systems, the potential business disruption from equipment failure or data loss may be even greater. Since conventional property
} 
Dos seguros de engenharia, conatos à infortunística ligada às máquinas e equipamentos, descendem os seguros de construção. Há países em que a expressão seguro de engenharia se aplica num primeiro significado às chamadas "garantias de riscos operacionais com quebras de máquinas", enquanto o seguro atinente aos projetos de engenharia de construção, instalação e montagem são mais conhecidos sob a expressão seguro de construçãoo. ${ }^{262}$ Os seguros atinentes às construções, em particular, surgem nos anos 1930 e se desenvolvem mais enfaticamente após a Segunda Guerra, ao serem intensamente demandadas obras de reconstrução de infraestrutura e edificações em geral, como enfatiza BUNNI:

The concentrated rebuilding programmes in the devastated areas of the world, accompanied by the rapid technological advances which took place in new materials and methods of construction, consolidated the principles of risk, responsibility, liability and indemnity in that area which gave rise, in one way another, to a strong need for construction insurance. $^{263}$

Uma das principais características desses seguros relacionados com os riscos da engenharia consiste no fato de que, desde sua origem, tendem à compreensão, nas garantias que oferecem, da maior amplitude de interesses e riscos e a se estenderem pelo período integral dos empreendimentos assegurados. Referindo-se aos seguros de instalação e

insurance does not cover these losses, mitigation of such risks through equipment breakdown insurance is not an optional "nice-to-have," but an essential management tool."

262 "The types of insurance that come under the general term of 'engineering insurances' may be subdivided into two groups: insurances covering permanently installed risks for an indefinite period, and insurances covering temporary, nonrecurring risks. The first group consists above all of machinery, machinery loss of profits (MLOP), electronic equipment (EE or low voltage), and, in the United Kingdom and other markets influenced by British insurers, boiler insurance. Since this type of insurance cover is for long-term protection of the insured objects, policies are generally renewed annually. In addition to machinery guarantee insurance, the second group comprises in particular erection all-risks (EAR) and contractors' all-risks (CAR) insurance, where the term of cover is naturally limited to the guarantee period or the period of erection and construction." GERATHEWOHL, Klaus et. alli. Reinsurance Principles and Practice. vol. II. p. 149-150. Tradução livre: "Os tipos de seguro incluídos sob o termo geral de 'seguros de engenharia' podem ser subdivididos em dois grupos: seguros cobrindo riscos permanentemente instalados por um peíodo indefinido, e seguros cobrindo lucros cessantes, não recorrentes. O primeiro grupo consiste acima de tudo em maquinário, lucros cessantes do maquinário do maquinário (MLOP ['machinery loss of profits']), equipamento eletrônico (EE ou baixa voltagem) e, no Reino Unido e outros mercados influenciados pelas seguradoras britânicas, seguro de caldeira. Como esse tipo de cobertura de seguro é para a proteção a longo prazo dos objetos segurados, as apólices em geral são renovadas anualmente. Somando-se ao seguro de garantia do maquinário, o segundo tipo compreende, em particular, seguro contra todos os riscos de edificação (EAR [erection all-risks]) e contra todos os riscos de montagem e instalação (CAR [contractors'all-risks]), em que a duração da cobertura é naturalmente limitada ao período de garantia ou ao período de montagem e construção."

263 BUNNI, Nael G. Risk and Insurance in Construction, op. cit. p. 5. 
montagem $\left(\mathrm{EAR}^{264}\right)$ e de construção $\left(\mathrm{CAR}^{265}\right)$, GERATHEWOHL também observa que

"a cobertura assim oferecida por esses seguros é talhada para os interesses variados de diferentes detentores de apólices [segurados] ${ }^{266}$

Essa característica da abrangência dos seguros de construção é enfatizada por BUNNI, que a recolhe na publicação comemorativa do centenário da experiência com seguros de engenharia da Companhia Resseguradora de Munique:

Diferentemente dos seguros de engenharia, que surgiram na Inglaterra com a Revolução Industrial nos meados do século XIX, a necessidade de segurar vários aspectos de um projeto de construção durante o período de construção foi reconhecida quando as formas padrão de contrato se desenvolveram. A mais antiga exigência de o contraente fazer seguro contra todos os riscos apareceu em 1929 nos contratos individuais de engenharia civil, na construção da Ponte Lambeth sobre o Tâmisa, em Londres. Na Alemanha, esse tipo de seguro foi introduzido em 1934, fazendo uso de termos e condições derivados de um seguro contra todos os riscos de edificação, desenvolvido para a edificação e o teste de instalações industriais, que havia sido lançado em $1924 .^{267}$

264 "EAR insurance covers machinery and plant during erection and testing at the erection site as well as installed (i.e. erected) machinery during conversion or any other disassembly or reassembly process. Coverage is also provided for erection equipment. Indemnification is thus granted for material damage sustained on account of a 'sudden and unforeseen' event during erection and testing, and covers nearly all hazards with just a few exclusions (in particular war, civil war, nuclear energy). EAR insurance is therefore tailored to the needs of policyholders engaged in the erection of machinery and plant." GERATHEWOHL, Reinsurance Principles and Practice. op. cit., p. 152. Tradução livre: "O seguro EAR ["erection all-risks"] cobre maquinário e instalações durante a montagem e os testes no local de montagem, assim como o maquinário instalado (isto é, montado) durante o processo de conversão ou durante qualquer outro processo de desmontagem ou remontagem. A cobertura também abrange o equipamento de montagem. Indenização é portanto concedida para danos materiais sofridos devido a um evento 'repentino e imprevisto' durante a montagem e os testes, e cobre praticamente todos os danos com apenas poucas exclusões (particularmente guerra, guerra civil, energia nuclear). O seguro EAR é, por isso, talhado para as necessidades dos detentores de apólices engajados na montagem de maquinário e instalações."

265 "Contractors' all-risks (CAR) insurance provides protection during the construction or conversion of buildings against material damage suffered by the building under construction and, if so agreed, against material damage to adjacent buildings already in existence, even if they belong to third parties." Idem, p. 152-53. Tradução livre: "O seguro contra todos os riscos do contraente (CAR [contractor all-risks]) oferece proteção durante a construção ou a conversão de edifícios contra danos materiais sofridos pelo edifício em construção e, se isto for acordado, contra dano material a edifícios adjacentes já existentes, mesmo que pertencentes a terceiros."

${ }^{266}$ GERATHEWOHL, Reinsurance Principles and Practice. op. cit., p. 153. Original em inglês: "[t]he coverage thus offered by these insurances is tailored to the varying interests of different policyholders."

${ }^{267}$ BUNNI, Nael G. Risk and Insurance in Construction, op. cit., p. 15. Original em inglês: "As distinct from engineering insurance, which began in England with the industrial revolution around middle of the nineteenth century, the necessity to insure various aspects of a construction project during its period of construction was recognised when the standard forms of contract were developed. The earliest contractor's all risks insurance requirement appeared in individual civil engineering contracts as early as 1929 for the construction of the Lambeth Bridge over the Thames in London. In Germany, this type of insurance was introduced in 1934 using terms and conditions derived from erection all risks insurance developed for erection and testing industrial facilities, which had been launched in 1924." 
A amplitude do conteúdo e da duração do seguro de riscos de engenharia também é encontrada nas Condições Gerais do Contrato de Construção de Obras Civis da Comissão de Fornecedores de Energia da Irlanda, de 1935:

Cláusula 26 - Seguro

O Contraente deve segurar, com uma Companhia previamente aprovada pelo Conselho, por escrito, as instalações e os materiais que possam temporariamente estar no local e deve mantê-los segurados contra a destruição ou dano pelo valor integral dessas instalações e materiais até a finalização dos trabalhos. E ele deverá, de tempos em tempos, quando isso for solicitado pelo Engenheiro, apresentar para inspeção a apólice e os recibos do prêmio. Todas as quantias recebidas sob tais apólices deverão ser aplicadas na ou para a reconstrução ou substituição das instalações e materiais destruídos ou danificados, mas esta provisão não afetará as responsabilidades do Contraente no âmbito do Contrato. ${ }^{268}$

Os riscos da engenharia sofrem importantes modificações após a segunda grande guerra, com o surgimento de novos materiais e metodologias construtivas, enfim, com o avanço tecnológico das artes de construir, montar e instalar.

Percebe-se que as seguradoras sentem dificuldade de acompanhar pari passu a forte mudança, o que cria uma "diferença significativa entre as exigências das condições do contrato e o que o mercado de seguro estava disposto a segurar" ${ }^{269}$, determinando inúmeras mudanças nos standards contratuais com o objetivo de atender à necessidade de proteção exigida pela engenharia e de promover a eliminação de descompassos entre os interesses asseguráveis e os riscos a serem enfrentados, de um lado, perante as coberturas de seguro, de outro. ${ }^{270}$

É importante enfatizar que os seguros, notadamente os aplicáveis à engenharia e aos riscos operacionais das empresas de extração, fabricação, serviços e logística, entre outros, "desenvolveram-se e difundiram-se como um resultado das necessidades e demandas da sociedade" 271 , e o fato de existirem por si "influenciou desenvolvimentos em

\footnotetext{
${ }^{268}$ BUNNI, Nael G. Risk and Insurance in Construction, op. cit., p. 15. Original do inglês:

"Clause 26 - Insurance

The Contractor shall insure with a Company previously approved by the Board in writing such plant and materials as may for the time being be upon the site and shall keep them insured against destruction or damage for the whole value of such plant and materials until the completion of the Works. And he shall, from time to time, when so required by the Engineer, produce the policy and the receipts for the premium for inspection. All monies received under such policies shall be applied in or towards the reconstruction or replacement of the plant and materials destroyed or damaged, but this provision shall not affect the Contractor's liabilities under the Contract."

${ }^{269}$ Original do inglês: "significant difference between the requirements of the conditions of contract and what the insurance market was prepared to insure".

${ }^{270}$ Idem, p. 16.

${ }^{271}$ Original do inglês: “developed and spread as a result of society’s needs and demands”.
} 
outras facetas da sociedade, formando um diálogo entre o seguro e, por exemplo, o direito ou as finanças". 272

Essas funções securitárias já foram vistas no capítulo em que cuidamos da socialidade do seguro. As obras de engenharia em geral sempre se caracterizam pela interação de suas etapas. Unem-se num todo indissociável a decisão sobre o local onde será feita a obra ou seu traçado, as investigações de solo, os projetos, a escolha dos materiais, sua fabricação, os métodos construtivos adotados e a sua execução, as decisões de campo, os testes de comissionamento, enfim, todas as etapas ou fases da obra ligam-se e interagem, umas com as outras. Isso recomenda que os seguros sejam desenhados para contemplar essa totalidade. Um defeito de fabricação ou execução, por exemplo, uma simples falha de leitura das investigações preliminares ou um erro de projeto qualquer, podem gerar prejuízos para os interessados no empreendimento de engenharia que somente surgirão, ou se tornarão conhecidos, quando a obra, já completa, for submetida aos testes finais.

Atualmente, a empreitada com cláusula "turn key", ou seja, obrigando o construtor até o esgotamento da conclusão do empreendimento, que deve ser entregue ao contratante pronto para funcionar com plena utilidade, é uma das formas mais comuns de contratos de construção, instalação e montagem, no âmbito das obras do setor privado, como acontece com a construção de unidades industriais, e nas que têm a participação do Estado, como é o caso das vias de transporte, portos e projetos para a produção de energia.

Por essas razões, a unidade técnica do risco, a possibilidade de os acidentes decorrerem da interação entre atos e fatos diversos, ou mesmo a probabilidade de que manifestações danosas de causas situadas numa fase somente possam ser percebidas e compreendidas etiologicamente em momento futuro, determinam a celebração desses seguros na modalidade "all risks", isto é, garantindo todos os interesses contra todos os riscos.

Outro aspecto interessante é o de que os seguros de riscos de engenharia, especialmente os que são praticados no Brasil sob essa denominação, que são aqueles atinentes às instalações e montagens de equipamentos industriais e estruturas em geral e às construções de obras civis em geral, apesar de terem suas coberturas modeladas país a país, não encontram suficiente base estatística para uma adequada solução atuarial (fixação da taxa para cálculo do prêmio), dependendo de forma muito especial da estrutura de

${ }^{272}$ Idem, p. 7. Original do inglês: "influenced developments in other facets of society, forming dialogue between insurance and, for example, law or finance". 
resseguro, pois aqui o universo em que os riscos são dispersos é muito mais amplo do que o universo de dispersão das carteiras de cada seguradora:

Uma característica que distingue os seguros de engenharia da maioria das outras classes de seguro de propriedade é a ausência de um sistema detalhado de precificação (tarifas) em grandes setores dos negócios de engenharia. Enquanto, no seguro de maquinário, estatísticas significantes e válidas estão disponíveis para o cálculo dos prêmios para a maioria dos tipos de máquina - embora não para os modelos mais recentes -, não é possível, particularmente no caso dos seguros EAR e CAR, estabelecer valores precisos de prêmios com base na estatística. Em vez disso, a única possibilidade é compilar diretrizes de classificação com certa margem de variação estendendo-se acima e abaixo do valor médio dos prêmios - cada risco exigindo assim o cálculo individualizado do prêmio que leve em consideração as características técnicas do projeto em questão, sua exposição específica a forças maiores, etc. A cooperação com um ressegurador experiente e especializado na avaliação e classificação de riscos proporciona ao segurador direto nítidas vantagens neste contexto. ${ }^{273}$

Os principais problemas que afligem os seguros de riscos de engenharia no Brasil, que apresentaremos a seguir, não incidem apenas sobre os seguros de riscos diretos da construção, instalação, montagem e garantia de manutenção dos projetos ou empreendimentos de engenharia. Embora não nos detenhamos a respeito, eles também afetam os seguros de responsabilidade civil do construtor, instalador e montador, os seguros de dano direto e de responsabilidade atinentes aos riscos operacionais dos empreendimentos. Em certa medida, atuam também sobre os seguros que caucionam as obrigações dos contratados para os trabalhos de engenharia, desde o projetista até os testadores da obra.

\subsection{Crise do seguro de riscos de engenharia no Brasil}

\subsubsection{Negação do interesse e redução do conteúdo de garantia dos seguros de riscos de engenharia}

\footnotetext{
${ }^{273}$ GERATHEWOHL, op. cit., p. 159-60. Original em inglês: "One feature that distinguishes engineering insurances from most of the other classes of property insurance is the lack of detailed pricing system (tariffs) in large sectors of engineering business. While, in machinery insurance, meaningful and valid statistics are available for calculating the premiums for most types of machines - although not for the more recent models -, it is not possible, particularly in EAR and CAR, to establish accurate premium tariffs on the basis of statistics. Instead, the only possibility is to compile rating guidelines with a certain bandwidth extending above and below the mean premium rates - each risk thus requiring individual premium calculation that makes due allowance for the technical features of the project concerned, its specific exposure to acts of God, etc. Cooperation with an experienced reinsurer specialized in assessing and rating risks provides the direct insurer with distinct advantages in this context."
} 
O interesse é elemento essencial aos seguros. Doutrina internacional ${ }^{274}$ e brasileira $^{275}$ apontam para a relação econômica entre o segurado e o bem da vida.

A teoria do interesse, o compreender que é um interesse que se protege através do contrato de seguro, e não o bem da vida que projeta esse interesse para uma diversidade de sujeitos de direito que com ele mantém uma relação econômica, esse modo de perceber é onde se pode encontrar a própria função do contrato de seguro, como ressalta Valeria DE

\section{LORENZI:}

O conceito de interesse foi reformulado pela teoria indenitária moderna. O interesse é normalmente considerado uma relação de natureza econômica entre um sujeito e um bem. O risco é a possibilidade de lesão do interesse; o dano, a lesão do interesse. A prestação do seguro é voltada ao ressarcimento do dano do segurado, antes eventual e depois atual; e nela deve se encontrar a função do contrato de seguro (art. 1.882, 1.904, $\left.1.905, \S 1^{\circ}, 1908, \S 1^{\circ}, \mathrm{CC}\right)$.

O interesse, como exposto, é uma abstração econômica do bem segurado, da coisa segurada, considerados relacionados com quem se assegura. $\mathrm{O}$ interesse liga o bem ao sujeito, torna subjetivo, relativo ao sujeito; o bem, a coisa exposta ao risco, e, todavia, é suscetível da avaliação econômica em si: o interesse é subjetivo, mas, ao mesmo tempo, é objetivo. $\mathrm{O}$ interesse é o quid exposto ao risco, é o pressuposto de validade do contrato de seguro.

De acordo com os defensores, a teoria do interesse revelaria sua superioridade na explicação da possível coexistência de uma pluralidade de seguros, de diferentes formas, sobre o mesmo bem; nesse caso, não seriam segurados riscos diversos, mas interesses diversos presentes no bem (por exemplo: do proprietário, do usufrutuário, do motorista, do credor hipotecário, etc).

O conceito de interesse, como relação entre um sujeito e um bem que possui um valor econômico, que é assegurado, e que pode ser lesado, cuja

${ }^{274}$ HALPERIN, Isaac. Seguros: Exposición crítica de las leyes 17418, 20091 y 22400. 3. Ed. Buenos Aires: Depalma, 2001, p. 889-893: "El concepto de interés asegurable adquiere en el contrato de seguro una importancia extraordinaria, porque constituye el objeto del contrato; su existencia es esencial para legitimar el contrato e impedir que degenere en una apuesta, y porque en el seguro de daños, es la medida de la indemnización."

${ }^{275}$ COELHO, Fábio Ulhoa. Curso de Direito Civil. $2^{a}$ ed. São Paulo : Saraiva, 2007. Vol. 2, p. 353-354: "Segurado é o titular direto do interesse garantido. Normalmente é ele o contratante do seguro e seu beneficiário; existem casos, entretanto, em que o seguro é contratado por ou liquidado em favor de quem titulariza apenas interesse indireto sobre a garantia." PONTES DE MIRANDA, Francisco Cavalcanti. Tratado de direito privado - Parte especial, $3^{\mathrm{a}}$ ed. São Paulo : RT, 1984, vol. XLV, p. 275: “O que se assegura não é propriamente o bem, razão porque, nas expressões seguro de bens ou seguros de coisas e seguro de responsabilidade, há elipse. O que se segura é o status quo patrimonial ou do ser humano (acidentes, vida). Segura-se o interesse positivo como se segura o interesse negativo. Assim, há o seguro contra incêndio, o seguro de vida, o seguro de responsabilidade, que é o seguro para indenizar o que resulte de dívida ou obrigação que nasça ao segurado. (...)." Ver tb. TEPEDINO, Gustavo; BARBOZA, Heloisa Helena; MORAES, Maria Celina Bondin de. Código Civil interpretado conforme a Constituição da República, vol. 2. Rio de Janeiro: Renovar, 2006, p. 561. VENOSA, Sílvio de Salvo. Direito civil: contratos em espécie, 5a ed. São Paulo: Atlas, 2005, p. 370-377. . POLIDO, Walter A. Contrato de seguro: novos paradigmas. São Paulo : Editora Roncarati, 2010, p. 107. 
lesão constitui o dano e, portanto, enseja o ressarcimento, está ligado à teoria indenitária e ao princípio indenitário. ${ }^{276}$

Até a década de 1980, a praxe securitária brasileira guiou-se primordialmente segundo a teoria do interesse. O seguro de Itaipu Binacional, projeto da década de 1970, por exemplo, funcionava a partir da consideração dos interesses dos segurados nos bens que compunham o empreendimento. ${ }^{277}$ A apólice de Itaipu acabou servindo de modelo para o mercado.

A solução adotada fora a inclusão, estampada a partir de então nos seguros de construção, de uma cláusula (Cláusula II) nas condições especiais para obras civis em construção dizendo que “(...) a Seguradora se obriga a indenizar o Segurado pelas avarias, perdas e danos materiais, decorrentes de acidentes de origem súbita e imprevista, causados aos bens descritos nesta apólice por qualquer causa, exceto os riscos excluídos.”278

Ao lado dessa cláusula, a qual deixa claro que o seguro é contra todos os riscos e que cobrirá não apenas avarias ou danos físicos, mas também os demais tipos de perdas e danos, seguia disposição nas condições particulares expressando que "A 'Modalidade de

${ }^{276}$ LORENZI, Valeria De. Contratto di assicurazione - Disciplina giuridica e analisi econômica. Padova: 2008, p. 184-185: "Il concetto di interesse è stato rielaborato dalla teoria indennitaria moderna. L'interesse è ritenuto normalmente una relazione di natura economica tra un soggetto e un bene, il rischio è la possibilità di lesione dell'interesse, il danno la lesione dell'interesse; la prestazione dell'assicuratore è volta a risarcire il danno, prima eventuale, poi attuale, dell'assicurato, e in essa è da ritrovare la funzione del contratto di assicurazione (artt. 1882, 1904, 1905, $1^{\circ}$ co., 1908, $1^{\circ}$ co., c.c.). L'interesse, quale esposto, è un'astrazione economica del bene assicurato, della cosa assicurata, considerati in collegamento con chi si assicura. L'interesse lega il bene al soggetto, rende soggettivo, relativo al soggetto, il bene, la cosa esposta al rischio, $\mathrm{e}$, però, è suscettible di valutazione economica in sé: l'interesse è soggettivo, ma, al tempo stesso, è oggettivo. L'interesse è il quid esposto al rischio, è presupposto di validità del contratto di assicurazione. Secondo i fautori, la teoria dell'interesse rivelerebbe la sua superiorità nella spiegazione della possibile coesistenza di una pluralità di assicurazioni, a diverso titolo, sul medesimo bene; in tale ipotesi, non sarebbero assicurati rischi diversi, ma interessi diversi presenti sul bene (ad esempio, del propietario, dell'usufruttuario, del conduttore, del creditore ipotecario, ecc.). Il concetto di interesse, come rapporto tra un soggetto e un bene avente un valore economico, che viene assicurato, che può essere leso, la cui lesione costituisce danno, quindi dà luogo a risarcimento, è unito in dottrina alla teoria indennitaria e al principio indennitario."

277 O texto da apólice pertinente ao seguro dos riscos de engenharia, fornecimento, transporte e responsabilidade civil atinentes ao projeto binacional, então a maior obra de engenharia da nossa história, somente veio a ser escrito nos anos 1980. O consenso guiava sem maiores conflitos o funcionamento do seguro no Brasil, supervisionado diretamente pelo ressegurador monopolista, que também tinha a competência para a regulação e liquidação dos sinistros, sob assistência da seguradora líder. A redação da apólice foi escrita a partir das atas de decisões do comitê de seguro da obra, do qual participavam os governos brasileiro e paraguaio, os administradores do empreendimento, as seguradoras de ambos os países e o Instituto de Resseguros do Brasil, graças aos esforços do Sr. Fernando Lopes Nunes, à época vicepresidente técnico da Companhia de Seguros Aliança da Bahia, líder do cosseguro brasileiro, conhecido no empreendimento como "Mr. Acta", e dos então diretores do IRB - Instituto de Resseguros do Brasil, Luiz de Souza Alves Dulce Pacheco Fonseca Soares e Aristeu Siqueira da Silva.

${ }^{278}$ Texto da apólice emitida em 1987 pela Companhia de Seguros Aliança da Bahia para garantir a Construtora Norberto Odebrecht S.A. e a Petrobras - Petróleo Brasileiro S.A. contra os riscos relacionados com a construção do Terminal Portuário do Sergipe. 
Seguro' definida na Cláusula II anterior destina-se a amparar os riscos inerentes à execução do Projeto do Terminal Portuário de Sergipe previsto no Contrato n. 2-811-0050-87 (...) abrangendo as seguintes principais etapas da construção (...)”.

Os interesses garantidos, portanto, eram aqueles sujeitos aos riscos incidentes sobre a execução do empreendimento ou projeto. Entendia-se, na prática das regulações de sinistro, como ocorreu com a solução da regulação de sinistro sofrido no âmbito do terminal sergipano ${ }^{279}$ que o seguro garantia, assim, os interesses do segurado na execução do projeto da obra de engenharia, devendo isso disparar a cobertura do seguro e determinar os prejuízos a serem indenizados.

A doutrina do interesse está plasmada na primeira regra atinente ao contrato de seguro do Código Civil, o art. 757, e alguns autores consideram-no causa, enquanto outros optam por ser ele o objeto do contrato de seguro; a nosso ver consiste no objeto mediato do contrato e sua compreensão é de grande utilidade para que o seguro possa cumprir sua função social:

\begin{abstract}
A boa compreensão do interesse, legítimo e real, como elemento do contrato de seguro, dele se extraindo consequências jurídicas, vem ao encontro da ideia de comutatividade do comércio jurídico, pautada pela regra da adequação entre as prestações, não obstante o princípio hipertrofiado pela tradição liberal segurado o qual o contrato é lei entre as partes. As soluções obrigacionais devem ser no sentido da maior reciprocidade de interesses de modo a evitar que a indenização beneficie aquele que não possui legitimidade, ou que a ausência de interesse daquele que figura no contrato sirva de escudo para o não cumprimento de obrigação perante o verdadeiro segurado. Como se sabe, o pacta sunt servanda sofre ainda, no Direito contemporâneo, os temperos da boa-fé objetiva e da moralização das relações econômicas, fazendo sobressair a função social do contrato, acolhida no novo Código como princípio (art. 421) de ordem pública inderrogável (art. 2.035, parágrafo único). ${ }^{280}$
\end{abstract}

A tentativa de sublimação da teoria do interesse tem-se constituído num dos principais artifícios dos seguradores e resseguradores para deprimir as coberturas de seguro e para rechaçar ou reduzir a grandeza das prestações em caso de sinistro, especialmente nos seguros de riscos operacionais e de engenharia ou construção.

Tem sido comum no Brasil a tentativa de aniquilamento das potencialidades da teoria - o que sucede enfaticamente com os seguros de riscos de engenharia -, e é questão conhecida no estrangeiro, já tendo levado a disputas nos países anglo-saxões.

\footnotetext{
${ }^{279}$ Rompimento do quebra mar ocorrido em 12 de outubro de 1989.

280 TZIRULNIK, Ernesto; CAVALCANTI, Flávio de Queiroz B.; PIMENTEL, Ayrton. O Contrato de

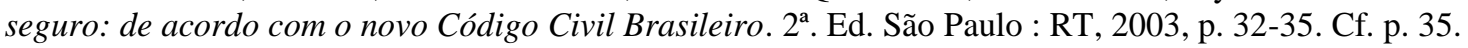


G.C.A. DICKSON e J.T. STEELE, ao cuidarem do interesse segurado, lembram que a matéria já fora examinada pelo judiciário inglês no século XIX, decidindo-se que "não se garantem os tijolos e materiais utilizados na construção da casa, mas o interesse do segurado no objeto do seguro."281 Da mesma forma, a Corte Federal em Tucson, nos Estados Unidos da América do Norte, ao discutir a definição de "dano físico", considerou "arcaica" a definição tradicional que exige lesão física a uma coisa segurada, como relatam Doug BERRY e Butler PAPPAS a respeito de caso em que a companhia seguradora exerceu uma ação declaratória contra sua segurada que havia sofrido uma interrupção de atividades em razão de perda de energia, com o objetivo de confortar a negativa de pagamento de indenização por ausência de dano físico. ${ }^{282}$

John HANSON e Christopher HENLEY também registram a recusa de uma corte norte-americana a acatar a alegação de que deveria incidir a limitação da garantia a danos físicos, e o ombudsman de seguros acatou a pretensão de estender-se a cobertura de dano material para abarcar perdas de utilidades, como os custos para desentupimento de chaminé, em seguros residenciais. ${ }^{283}$

A seguir, examinaremos a regulamentação sobre seguro de riscos de engenharia ou construção, desde os anos 1970 até o presente, onde ficará evidenciado que a teoria do interesse veio sendo despejada pela administração pública brasileira, privilegiando o

${ }^{281}$ DICKSON, G.C.A. e STEELE J.T. Introduction to Insurance. Londres: Financial Times Management $2^{\mathrm{a}}$. ed., 1984, p. 35: "It is now extremely important to grasp one fundamental fact which may appear, at first, to be paradoxical. By this we mean that it is not the house, ship, machinery, potential liability or life that is insured. It is the pecuniary interest of the insured in that house, ship, machinery, etc. which is insured. The subject matter of the contract is the name given to the financial interest which a person has in the subject matter of the insurances. This concept is at the root of the doctrine of insurable interest and was expounded very clearly in the case of Castellain v. Preston (1883) in these words: "What is it that is insured in a fire policy? Not the bricks and materials used in building the house, but the interest of the insured in the subject matter of insurance.' This is one of those questions that is well worth committing to memory as it conveys in a few words a very complex concept."

${ }^{282}$ BERRY, Doug e PAPPAS, Butler. 'Physical Damage'. In: The First-Party Property Policy: A New Definition Coming?. Disponível em http://www.irmi.com/expert/articles/2000/berry09.aspx?cmd=print. Acesso em 17 de novembro de 2012: "In American Guarantee \& Liability Ins. Co. v Ingram Micro, Inc., 2000 U.S. Dist. LEXIS 7209 (DC Ariz April 18, 2000), the district court considered the defendant's claim for business and service interruption following a power outage due to a ground fault in the fire alarm panel at its Tucson Data Center. (...) the insurer filed a declaratory action on the issue of whether the power outage caused 'direct physical loss' or damage from any cause, howsoever or wherever occurring.(...) Following cross-motions for summary judgment on the issue, the court rejected the insurer's traditional definition of 'physical damage' and accepted Ingram's 'broader definition' which included 'loss of use and functionality'." ${ }^{283}$ All Risks Property Insurance - Londres: LLP - Lloyd's of London Press Ltd., 1a ed., 1995, p. 4: "In a recent US authority, however, a court found that where there was no clear definition of physical loss or damage it decided that 'damage' was not necessarily limited by the phrase 'physical' unless it was specifically state to be such. (...) It is just a reminder that insurers cannot be too careful in drafting key phrases in polices. (...) On household policies the Insurance Ombudsman has extended the meaning of 'damage' to include impairment of usefulness. For example, in one case the assured successfully claimed for the cost of unblocking a pipe." 
interesse dos seguradores e resseguradores em detrimento dos segurados e das atividades empresariais, especialmente aquelas atinentes a obras de infraestrutura.

$\mathrm{O}$ ataque verte não apenas para (i) reduzir as garantias, seja restringindo a definição de sinistro indenizável para "danos à propriedade física tangível”, como também para (ii) permitir que as companhias possam evitar a prorrogação dos seguros dos projetos de engenharia, naturalmente sujeitos a atrasos por força das mais diversas razões. Também aludiremos a outras disfunções, como a condescendência das autoridades do setor securitário com (iii) a morosidade e o regime inquisitorial das regulações de sinistro, com (iv) o uso indiscriminado de arbitragens onerosas para os segurados e beneficiários brasileiros e, finalmente, (v) o esvaziamento da obrigação legal de ressarcimento das despesas de salvamento.

\subsubsection{Regulamentação dos seguros de risco de engenharia no Brasil}

No mercado brasileiro, até o advento do chamado "Plano Diretor" instituído por Decreto sem número publicado em 1990, os contratos de seguro de todas as seguradoras brasileiras viam-se sujeitos às mesmas cláusulas e condições, fixadas pela Superintendência de Seguros Privados - SUSEP, pelo Instituto de Resseguros do Brasil, posteriormente denominado IRB Brasil Resseguros S.A. e pelo Conselho Nacional de Seguros Privados - CNSP. ${ }^{284}$

Vigia a chamada "tarifação", que alcançava não apenas as "notas técnicas" pertinentes a cada modalidade, mas o próprio conteúdo contratual. ${ }^{285}$ Posteriormente, por

\footnotetext{
${ }^{284}$ Sobre o referido "Plano Diretor", cf., p. ex., José T. C. de MOURA e Walter GRANEIRO, Em Busca da Nova Ordem Financeira. Rio de Janeiro: Rio Fundo, 1992.

${ }^{285}$ Cf. Ernesto TZIRULNIK e Paulo Luiz de Toledo PIZA, "Notas sobre a natureza jurídica e efeitos da apólice de seguro no direito brasileiro atual", op. loc. cit., onde se sugeria, à vista da tarifação então vigente, a semelhança das apólices aos chamados "atos união". Cf. tb. cf. Eros Roberto Grau, Elementos de Direito Econômico, S. Paulo, RT, 1981, esp. p. 78-79, onde se refere às "cláusulas padronizadas por ato estatal". O art. $8^{\circ}$ do Decreto n. 60.459, de 1967, antes da sua alteração pelo Decreto n. 605, de 17.7.1992, era do seguinte teor: "Art. $8^{\circ}$. As Sociedades Seguradoras submeterão à aprovação da SUSEP as suas tarifas de prêmios mínimos, dependendo igualmente dessa.aprovação quais quer alterações a introduzir ou a inclusão de novas classes de riscos. Parágrafo único. Esta obrigação abrange somente as modalidades de seguros para as quais não exista tarifa única já aprovada, para uso de todo o mercado segurador." Atualmente, o art. $8^{\circ}$ do Decreto n. 60.459, de 1967, tem a seguinte redação, dada pelo Decreto n. 3.633, de 18.10.2000: "Art. 8. As Sociedades Seguradoras enviarão à Superintendência de Seguros Privados - SUSEP, para análise e arquivamento, as condições dos contratos de seguros que comercializarem, bem como respectivas notas técnicas de prêmios. $\S 1^{\circ}$ A SUSEP poderá, a qualquer tempo, diante da análise que fizer, solicitar informações, determinar alterações, promover a suspensão do todo ou de parte das condições e das notas técnicas a ela apresentadas, na forma deste artigo. $\S 2^{\circ}$ As condições de seguro deverão incluir cláusulas obrigatórias determinadas pela SUSEP. $\S 3^{\circ}$ As notas técnicas de prêmios deverão explicitar o prêmio puro, o carregamento, a taxa de juros, o fracionamento e todos os demais parâmetros concernentes à mensuração do
} 
influxo do citado Decreto - que promoveu a chamada "destarifação" - as seguradoras passaram a predispor, embora limitadamente, pois sujeitas a regras administrativas e aos imperativos postos pelo IRB para fins de concessão de resseguro, o conteúdo das apólices que passariam a emitir. Isso, todavia, sem que se tivesse suprimido a sua sujeição ao controle pela citada SUSEP, pelo IRB, ou às regras postas pelo CNSP.

Nossos seguros haviam-se desenvolvido ao longo da intervenção estatal iniciada nos anos 1930 e as garantias oferecidas eram de boa qualidade.

O primeiro documento relevante sobre os seguros de riscos de engenharia atinentes a obras civis, instalações e montagens, também chamados seguros de construção, foi uma norma expedida pelo IRB, a Circular IRB PRESI-030 (RISEN-003), de 20.02.74.

A Circular IRB PRESI-030/74 continha regras importantes para o fortalecimento do conteúdo desses seguros.

Seu art. $2^{\circ}$ desse ato previa no seu item que "[o] prazo do seguro deverá coincidir com o período integral de duração da obra civil ou de montagem." Essa regra determinava que o empreendimento de engenharia deveria ser garantido do princípio ao fim, evitando períodos de exposição sem garantia de seguro. A vigência do seguro não se ateria ao prazo previsto para a execução integral da obra de engenharia que projetava os interesses garantidos pelo contrato de seguro, mas, isto sim, ao prazo real da obra, devendo a seguradora aditar a apólice para esse fim, para isso dispondo também o art. $2^{\circ}$ que "[a] prorrogação do prazo de vigência da apólice deverá ser efetuada por endosso."

$\mathrm{O}$ mesmo conforto que era outorgado pelo art. $3^{\circ}$ quanto à completude dos interesses garantidos, sendo ali previsto que a importância segurada necessariamente corresponderia (i) "com relação à cobertura de obras civis, ao valor integral dos bens segurados, após completada a construção, incluídas as parcelas de mão-de-obra, frete,

risco e dos custos agregados, observando-se, em qualquer hipótese, a equivalência atuarial dos compromissos futuros. $\S 4^{\circ} \mathrm{A}$ partir da data de publicação deste Decreto, os prêmios mínimos aprovados pela SUSEP passarão a ser obrigatoriamente adotados pelas Sociedades Seguradoras para todos os efeitos de cálculo de provisões técnicas e de resseguro, exceto nos casos previstos nos $\S \S 5^{\circ}$ e $6^{\circ}$ seguintes. $\S 5^{\circ}$ A SUSEP poderá aprovar notas técnicas atuariais para cálculo de provisões propostas por Sociedades Seguradoras, especificamente para cada caso. $\S 6^{\circ}$ Os planos de resseguro poderão, caso a caso, ser livremente negociados entre a Sociedade Seguradora e o ressegurador. $§ 7^{\circ}$ A SUSEP divulgará estudos, por ela aprovados, sobre taxas referenciais de prêmios, calculadas por entidades científicas ou representativas do mercado de seguros e de previdência privada, de molde a estabelecer bases atuariais adequadas às condições de risco conjunturalmente existentes. $\S 8^{\circ}$ Para efeito de base de cálculo das provisões técnicas, a SUSEP poderá exigir que as taxas referenciais mencionadas no parágrafo anterior sejam utilizadas. $\S 9^{\circ}$ Os seguros de vida que prevejam cobertura por sobrevivência somente poderão ser comercializados após prévia aprovação pela SUSEP dos respectivos regulamento e nota técnica atuarial. § 10. Nos seguros de que trata o parágrafo anterior, a obrigatoriedade de explicitação do prêmio puro na nota técnica atuarial só se aplica àqueles estruturados na modalidade de benefício definido". 
despesas aduaneiras, impostos e emolumentos, assim como os materiais ou itens fornecidos pelo proprietário" e (ii) "com relação à cobertura de montagem: ao valor integral dos bens segurados após completada a montagem, incluídas as parcelas de frete, despesas aduaneiras, impostos e emolumentos, e custo da montagem (inclusive o valor dos materiais fornecidos e da mão-de-obra eventualmente não incluídos no custo do contrato)".

A intenção de oferecer garantias integrais e abrangentes se confirmava no art. $7^{\circ}$, onde se estabelecia que "[o] seguro deverá abranger a totalidade das Obras Civis, sendo vedada a realização de seguros parciais que abranjam parte delas num mesmo local " e que “[o] seguro poderá, também, incluir, mediante verba própria, as obras temporárias indispensáveis à execução do projeto", sendo já predeterminada a taxa para o cálculo de prêmio das obras temporárias que se pretendesse garantir: "[o] prêmio devido para esta cobertura deverá corresponder à aplicação da taxa básica da apólice e das taxas das coberturas adicionais cabíveis, sobre o valor dessas obras".

Esse também era o tratamento dado no art. $9^{\circ}$ relativamente à garantia de desmontagem e remontagem de máquinas ou equipamentos usados, fixando-se como cláusula obrigatória a que estabelecia que para a determinação dos prejuízos indenizáveis, no caso de qualquer dano que pudesse ser reparado, deveria ser feita levando em conta o custo dos reparos necessários a restabelecer o bem sinistrado no mesmo estado que se encontrava imediatamente antes da ocorrência do sinistro, deduzido o valor dos salvados, devendo a seguradora também indenizar o custo de desmontagem e remontagem que se fizer necessário para os reparos, assim como as despesas normais de transporte, de ida e volta da oficina de reparos e despesas aduaneiras.

Caso os reparos fossem executados na oficina do próprio segurado, a seguradora ficava obrigada a incluir o custo do material e da mão-de-obra decorrentes dos reparos efetuados e mais uma percentagem razoável de custos fixos ou indiretos, sendo vedada à seguradora qualquer redução na indenização, a título de depreciação, com relação às partes substituídas. Na hipótese de se tratar de perda total, a seguradora fica obrigada a ter como base o real valor do bem sinistrado imediatamente antes da ocorrência do sinistro, calculando-se tal valor real mediante dedução de depreciação cabível do valor da reposição do objeto sinistrado, deduzido o valor dos salvados.

A seguradora também estava obrigada a indenizar as despesas aduaneiras, as despesas normais de transportes e de montagem, assim como as despesas normais de desmontagem do objeto destruído, apenas deduzindo o valor dos salvados. 
Como se verifica com grande facilidade, as normas expedidas pelo ressegurador monopolista, instrumento da política desenvolvimentista brasileira no setor securitário, buscavam obrigar as seguradoras a oferecerem um conteúdo mínimo que fosse compreensivo de todas as projeções do interesse, seja quanto à duração, seja quanto ao conteúdo do seguro e às indenizações em caso de sinistro.

Quase uma década após é editada a Circular SUSEP n. 016, de 14.04.1983. Vigorava o Código Civil de 1916.

A hipótese de reticência ou inexatidão das informações prestadas pelos segurado à seguradora na formação do contrato era regulada pelo art. 1.444 do CCB1916, segundo o qual a sonegação de informações relevantes para o juízo de subscrição ou para a taxação do prêmio determinaria a perda ao valor do seguro e ao pagamento do prêmio vencido. ${ }^{286}$ A matéria gerava muita litigiosidade em situações de sinistro envolvendo os mais diversos ramos de seguro, como ocorre até hoje, ao passo que o IRB e as poucas seguradoras que operavam o ramo de engenharia ou construção dispunham de equipes técnicas capazes de avaliar com boa margem de segurança os pressupostos para a subscrição, rareando a possibilidade de má informação, em geral envolvendo divergências entre as informações prestadas quando da simples cotação do seguro, que modulava a vontade das seguradoras, e as circunstâncias concretas ao tempo da apresentação da proposta de seguro levada em conta para a formação do negócio.

A Circular SUSEP n. 016/83, ao cuidar da questão relacionada com o agravamento do risco sobreveio apenas para confirmar o direito positivo. $\mathrm{Na}$ hipótese de suceder agravamento relevante ("além do que era possível antever no contrato"), o art. 1.453 do CCB1916 condicionava o direito da seguradora a aumento de prêmio à existência, no contrato, de previsão expressa neste sentido ${ }^{287}$ e previa a "perda do direito ao seguro" ou perda do direito à garantia (resolução do contrato) quando sucedesse um tal agravamento ou fosse ele iminente e o segurado não o comunicasse à seguradora. ${ }^{288}$

\footnotetext{
286 Art. 1.444. Se o segurado não fizer declarações verdadeiras e completas, omitindo circunstâncias que possam influir na aceitação da proposta ou na taxa do prêmio, perderá o direito ao valor do seguro, e pagará o prêmio vencido.

${ }^{287}$ Art. 1.453. Embora se hajam agravado os riscos, além do que era possível antever no contrato, nem por isso, a não haver nele clausula expressa terá direito o segurador a aumento do prêmio.

${ }^{288}$ Art. 1.454. Embora vigorar o contrato, o segurado abster-se-á de tudo quanto possa aumentar os riscos, ou seja contrário aos termos do estipulado, sob pena de perder o direito ao seguro.

Art. 1.455. Sob a mesma pena do artigo antecedente, comunicará o segurado ao segurador todo incidente, que de qualquer modo possa agravar o risco.
} 
No entanto, à época a doutrina passara a exigir o agravamento voluntário para que pudesse incidir a gravosa penalidade. ${ }^{289}$ A cláusula $8^{\text {a }}$ da Circular SUSEP n. 016/83, porém, reagindo à construção doutrinária, previu que na hipótese de o fato não ter sido comunicado pelo segurado à seguradora esta ficaria "isenta de responsabilidade pelo não cumprimento desta disposição e com o direito de cobrar prêmio adicional para a manutenção da cobertura, desde que tal modificação implique a agravação do risco".

No tocante aos seguros de Obras Civis em Construção e Instalação e Montagem, a cláusula $4^{\mathrm{a}}$, disciplinando os prejuízos Indenizáveis, esclarece que também serão indenizáveis as avarias, perdas e danos materiais sofridos e que não estejam especificamente excluídos nas Condições Especiais do seguro, o que abre para a seguradora a possibilidade de restringir a eficácia do seguro na apólice de sua emissão, o que torna a previsão pejorativa para os segurados e beneficiários em relação ao regime posto na anterior regra dos artigos $3^{\circ}$ e $7^{\circ}$ da Circular IRB PRESI-030/74.

De todo modo é importante reter que a norma diz que "serão indenizáveis as avarias, perdas e danos materiais", preservando a possibilidade de se compreender que as avarias equivalem aos danos físicos sofridos pelas coisas asseguradas e as perdas e danos

\footnotetext{
289 Miguel REALE, por exemplo, após pontuar que "a máxima pena aplicável nos domínios do Direito Privado" consiste em "privar um contrato dos seus efeitos naturais", destacava o cuidado do legislador ao disciplinar a matéria, "exigindo que o aplicador da pena não se deixe levar por elementos aparentes ('probabilidades infundadas') e só prive o seguro da eficácia quando haja elementos tangíveis que comprovem tenha o segurado efetiva e intencionalmente agido de modo a aumentar os riscos do contrato." ("A equidade nos contratos de seguro" in Teoria e Prática do Direito, S. Paulo, Saraiva, 1984, p. 307-318.) Quando muito, o entendimento era o de que a agravação dos riscos por fatores alheios ao segurado poderia, mas desde que havendo expressa disposição contratual na apólice nesse sentido, levar a um aumento do prêmio, consoante o disposto no então vigente art. 1.453 do Código Civil de 1916, ao qual se poderia equiparar o art. 769 do Código Civil vigente. Fábio Konder COMPARATO, a propósito dessas disposições, afirmou, no mesmo sentido, depois de esclarecer que não é qualquer agravação intencional do risco que dá ensejo à pena de caducidade, mas a agravação intencional que não leve em conta probabilidades infundadas (art. 1.456) e que importe "agravação essencial do risco segurado", pontuava que "no sistema do nosso Código Civil, a agravação não intencional do risco somente autoriza um aumento de prêmio, se a apólice for expressa nesse particular", para em seguida acrescentar que "o ônus da prova da agravação essencial do risco, acarretando a responsabilidade do segurado, incumbe inequivocamente ao segurador, segundo o princípio de que o devedor que se pretende liberado de sua obrigação deve fazer a prova do fato que autoriza essa liberação" (Novos Ensaios e Pareceres de Direito Empresarial, Rio de Janeiro: Forense, 1981, p. 363). À época, vale anotar, a disposição legal vigente não era tão clara em exigir a intencionalidade do ato, como acontece presentemente, observada a redação dos arts. 768 e 769 acima citados. À luz do atual diploma civil, por isso mesmo, Antonio JUNQUEIRA DE AZEVEDO sustentou a necessidade de prova da má-fé do segurado, para que se possa falar em agravação de risco capaz de exonerar o segurador do dever de indenizar. $\mathrm{O}$ autor, com efeito, depois de listar algumas normas sobre o contrato de seguro presentes no Código Civil em vigor, anotando que "todas exigem má-fé do segurado e prova dessa má-fé pelo segurador", destacou o seguinte: "Prosseguindo, veja-se que também o art. 768, que foi reformulado em relação ao Código Civil de 1916, trazendo expressamente a exigência de agravamento intencional do risco para se excluir a garantia do seguro", entendendo que essa prova "deve ser cabal" (Novos Estudos e Pareceres de Direito Privado, S. Paulo: Saraiva, 2009, p. 315 e ss.).
} 
materiais aos demais danos patrimoniais ou, na expressão cara para o seguro, demais interesses segurados afetados pelo sinistro..

Continuando a tendência depressora da eficácia dos seguros de que trata, a mesma cláusula $4^{\mathrm{a}}$ da Circular SUSEP n. 016/83 limitava o ressarcimento das despesas de salvamento, isto é, determinava o ressarcimento daquelas "que, antes da chegada do representante da Seguradora ao local do sinistro, tiverem sido realizadas para proteção dos bens sinistrados e, redução dos prejuízos", porém desde que tivessem "valor inferior ao custo do agravamento dos danos evitados", uma limitação que não existia à época.

A lei italiana que tem regra idêntica, proíbe a derrogação contrária aos segurados do direito ao reembolso das despesas de salvamento, como se vê com Antígono DONATI e Giovanna Volpe PUTZOLU:

As despesas devem ser reembolsadas pela seguradora, mesmo se o seu valor, juntamente com o dos danos, ultrapassar o montante segurado. Esta disposição visa evitar a preocupação de que com os custos excedentes ao montante segurado constituam um obstáculo para a operação de salvamento (art. 1914 co. 2) e é inderrogável em sentido desfavorável ao segurado (ver art. $1.932 \mathrm{cc}$ ).

O segurador não é, no entanto, obrigado a reembolsar os gastos feitos imprudentemente (por exemplo, despesas com aluguel de helicóptero para perseguir um ladrão que foge com bens roubados de valor módico). ${ }^{290}$

A doutrina formada em torno do parágrafo único do artigo $1.457^{291}$ e da regra do art. 1.461 do CCB1916 $6^{292}$ se encontrava pacificada quanto a ser devido integralmente o ressarcimento, independentemente da eficácia das medidas ou do seu valor ${ }^{293}$ e o direito

290 DONATI, Antígono; VOLPE PUTZOLU, Giovanna. Manuale di diritto delle assicurazioni. 10 $0^{\mathrm{a}}$ ed., Milão: Giuffrè Editore, 2012, p. 157: “3. Obbligo di salvataggio. (...) Le spese devono essere rimborsate dall'assicuratore anche se il loro importo unitamente a quello del danno supera la somma assicurata. Questa disposizione ha lo scopo di evitare che la preoccupazione di dover sostenere spese che comportino il superamento della somma assicurata costituisca una remora all'opera di salvataggio (art. 1914 co. $2^{\circ}$ ) ed è inderogabile in senso sfavorevole all'assicurato (v. art. 1932 c.c). L'assicuratore non è tuttavia tenuto a rimborsare spese fatte inconsideratamente (ad es. le spese per l'affitto di un elicottero per inseguire un ladro che fugge con una refurtiva di moderato valore."

${ }^{291}$ Art. 1.457. Verificado o sinistro, o segurado, logo que saiba, comunicá-lo-á ao segurador.

Parágrafo único. A omissão injustificada exonera o segurador, se este provar que, oportunamente avisado, lhe teria sido possível evitar, ou atenuar, as consequências do sinistro.

292 Art. 1.461. Salvo expressa restrição na apólice, o risco do seguro compreenderá todos os prejuízos resultantes ou consequentes, como sejam os estragos ocasionados para evitar o sinistro, minorar o dano, ou salvar a coisa.

293 Ver ALVIM, Pedro. O contrato de seguro. Rio de Janeiro: Forense, 1999, p.399-401: "340 - As providências tomadas no interesse do segurador que se beneficia com a redução dos prejuízos indenizáveis. Deve, pois, reembolsá-los ao segurado. (...) O legislador não estabelece critério para limitar os gastos de salvamento. Entende Vivante que podem ultrapassar o valor dos bens salvos, porque, limitando-se o reembolso àquele valor, irá recair sobre o segurado o azar do salvamento, o que poderia servir de pretexto para permanecer inativo no momento do sinistro, quando o socorro deve ser mais rápido e mais decidido. Pode acontecer que, não obstante todos os esforços e os gastos feitos pelo segurado, sejam menores os 
estrangeiro também enfatizava, como ocorre até hoje com a maioria dos ordenamentos nacionais.

Desde a Circular SUSEP n. 016/83, o regime do salvamento securitário veio sendo desconstruído pelas nossas autoridades administrativas, permitindo a confusão do salvamento e correlativa obrigação de reembolso de despesas pela seguradora com os danos e prejuízos cobertos e correlativa indenização. ${ }^{294}$

A questão é de relevância incomensurável para o funcionamento dos seguros, notadamente dos seguros de construção em que medidas de salvamento costumam ser demandadas e adquirem grande eficácia.

É necessário entender que, como acontecia no regime do CCB/1916, também hoje um segurado que quer proteger seu prédio de $\mathrm{R} \$ 100$ contra o fogo, não pode contratar seguro por $\mathrm{R} \$ 150$, pois o limite admitido pela lei é o valor do interesse segurado. Se ele fizer isso, contratar o seguro por valor maior, "perderá o direito o direito à garantia, além de ficar obrigado ao prêmio vencido" (art. 766 do Código Civil). Na verdade, quem fizer seguro por valor extravagante, fica sujeito a medidas criminais, pois "[n]o seguro de dano a garantia prometida não pode ultrapassar o valor do interesse segurado no momento da conclusão do contrato, sob pena do disposto no art. 766, e sem prejuízo da ação penal que no caso couber." (art. 778 do Código Civil).

O contrato de seguro de danos visa garantir o patrimônio de alguém em virtude da ocorrência de um risco. Num primeiro momento, essa garantia patrimonial se dá com a mera proteção do seguro, e para isso é que são feitas provisões e reservas capazes de preservar a solvabilidade do segurador, tornando-o apto para garantir o cumprimento das obrigações contraídas e, no caso de se realizar o risco coberto pelo seguro, dispor dos

resultados finais ou que não se tenha mesmo evitado a destruição total dos bens ameaçados pelo sinistro. Ocorre, também, que não há muito tempo para ponderar as medidas de salvamento. O tempo urge, a situação é aflitiva e a exaltação do estado de espírito que os acontecimentos provocam, nem sempre favorece o exame mais detido da melhor maneira de proceder em tais circunstâncias."

${ }^{294}$ A respeito, publicamos um artigo intitulado "A circular SUSEP n. 256/2004 e as medidas de salvamento", disponível em http://www.ibds.com.br/artigos/TZIRULNIK_Medidas_de_salvamento.pdf. Também em doutrina, abordando o regime do CCB1916, observamos que o salvamento não traduz atividade de recuperação dos danos e sim ação preventiva de danos obrigatória, no interesse da seguradora e do cumprimento da função social do seguro, a ser reembolsada (TZIRULNIK, Ernesto. Regulação de Sinistro (ensaio jurídico). $2^{\mathrm{a}}$ ed. Revista. São Paulo: Max Limonad, 2000, p. 95-6). A mesma posição é hoje sustentada por Walter Antonio POLIDO (Contrato de Seguro: novos paradigmas. São Paulo: Roncarati, 2010, p. 114-124). A jurisprudência brasileira não se formou, embora algumas manifestações revelem a compreensão sobre a diferença entre ressarcimento determinado pela lei e indenização fundada no contrato (Apelação Cível n. 761.071-5. Tribunal de Justiça do Paraná, 10ª Câmara Cível. Rel. Magistrada Denise Antunes, participaram Desembargadores Luiz Lopes (Presidente) e Arquelau Araújo Ribas. J. 30.08.2012), enquanto que a experiência arbitral, por certo mais densa, se vê subtraída do domínio social pelo encarceramento da experiência jurídica e da produção de precedentes que decorrem da sua confidencialidade estrita. "A circular SUSEP n. 256/2004 e as medidas de salvamento" 
meios financeiros destinados à reparação da lesão sofrida pelo segurado ou beneficiário do seguro. Nesse segundo momento, portanto, depois de verificado o sinistro, a proteção faz nascer a função de indenização do seguro.

Essa indenização depende do adequado estabelecimento de regras e limites, a se integrarem no chamado princípio indenizatório para que o seguro, à medida do contratado, sempre reposicione o segurado ou beneficiário para o estado ou situação patrimonial em que se encontrava antes do sinistro.

A atuação do princípio indenizatório deixaria de existir caso o segurado, vitimado pelo sinistro, ou sendo este iminente, não fosse recuperado das despesas feitas com o objetivo de evitar sua concretização e, acaso já ocorrido ou iminente, evitar ou atenuar os danos e prejuízos. Tais medidas correspondem a ações preventivas de sinistro e dano. São medidas diferentes da ação preventiva de realização de risco. A prevenção da realização do risco, assim como a prevenção do surgimento de risco (precaução), em geral não serão protegidas por meio de seguro, e nada têm a ver com sinistro ocorrido ou iminente. Por isso é importante deixar claro que o salvamento está no âmbito das ações preventivas de sinistro e dano.

Se o segurado ou beneficiário adotou as medidas ao seu alcance na tentativa de prevenir a concretização ou as dimensões do sinistro iminente, ou dos danos, ele poderá ter sido levado a gastar uma quantia importante e, ainda assim, sofrer a perda total do interesse que havia procurado garantir quando contratou o seguro. Poderá, por exemplo, perder os $\mathrm{R} \$ 100$ e mais $\mathrm{R} \$ 100$. Se o segurado, ou o beneficiário, deixar de adotar as ações preventivas de sinistro e dano, ele perderá o direito ao seguro (art. 771 do Código Civil vigente). Então, embora esteja obrigado a gastar com o salvamento, se ele receber apenas $\mathrm{R} \$ 100$ do seguro, terá persistido no todo o estado de prejuízo, deixando o seguro de cumprir, no mundo real, sua função indenizatória.

É por isso que o princípio indenizatório faz coexistirem o dever de salvamento com a obrigação da seguradora de prover os meios necessários para tanto (parágrafo único do art. 771), reembolsando o segurado. Caso esse reembolso fosse de $\mathrm{R} \$ 100$ e, portanto, consumisse todo o capital do seguro, o sinistro (os prejuízos do sinistro) jamais teria sido indenizado, ainda que estivesse "coberto".

Há legislações que preveem que as quantias a serem reembolsadas a título de salvamento devem ser deduzidas do valor da garantia do seguro ou importância segurada. Desse tipo é a portuguesa que, apesar de prever que tais quantias devem ser reembolsadas 
pelo seguro e antes do término da regulação e liquidação do sinistro (art. 127- Obrigação de reembolso), diz que "[o] valor devido pelo segurador (...) é deduzido ao montante do capital seguro disponível, salvo se corresponder a despesas efectuadas em cumprimento de determinações concretas do segurador ou a sua cobertura autónoma resultar do contrato." No mesmo sentido, o art. 40, da LCS da Venezuela (2001).

Não obstante o regime jurídico do contrato de seguro instaurado em Portugal, contudo, considerado excessivamente protetor das companhias de seguros por autores do porte de José Carlos Moitinho de ALMEIDA $^{295}$, não é representativo da experiência dogmática internacional. O Código Civil italiano, por exemplo, estabelece, no art. 1914, que as despesas de salvamento para evitar ou diminuir o dano devem ser reembolsadas pelo segurador, mesmo que, excedam a importância segurada quando somadas ao prejuízo indenizável. Essa mesma solução se encontra no art. 70 da Lei de Contrato de Seguro (LCS) suíça (alterada em 2004) e no art. 73 da LCS argentina (1967). A LCS espanhola (1980), no art. 70, limita o ressarcimento das despesas a montante equivalente ao da importância segurada. ${ }^{296}$

Embora a matéria não fosse polêmica, entre nós, desde o Código Civil de 1916, e a doutrina brasileira haja diferenciado o reembolso do salvamento da indenização dos danos, atualmente nos deparamos com (a) autores que consideram que o reembolso do gasto com o salvamento sempre é ilimitado quando não prefixado limite específico na apólice, (b) autores que consideram que o salvamento é limitado a uma vez a importância segurada quando não prefixado limite específico na apólice, (c) autores que defendem a livre fixação de limite para o salvamento, (d) autores que enfatizam a importância de que a fixação de limite deva ser coerente com a expectativa de medidas capazes de materializar a tentativa de salvamento e (e) apólices e regulamentos que convertem o salvamento em cobertura, confundindo os regimes e propiciando a conclusão de que as despesas de contenção fazem parte dos prejuízos indenizáveis.

A Circular SUSEP n. 016/83 também deprimiu a vigência dos seguros de riscos de engenharia. Sua cláusula $8^{\mathrm{a}}$ dispunha (i) que "a responsabilidade da Seguradora se inicia imediatamente após a descarga dos bens segurados no canteiro de obras, especificado na

\footnotetext{
${ }^{295}$ Contrato de seguro: estudos. Coimbra: Coimbra Editora, 2009, p. 5-7.

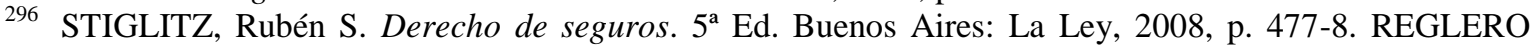
CAMPOS, L. F. et. al. Ley de contrato de seguro: jurisprudencia comentada. Navarra: Aranzadi, 2007, p. 366 e ss. SÁNCHEZ CALERO. F. Ley de contrato de seguro. (coord. F. Sánchez Calero). Madri: Edit. Aranzadi, 1999, p. 308. MAGALLANES, Pablo Medina. Ley sobre el contrato de seguro comentada. México: Porrúa, 2011, p. 201.
} 
apólice, respeitado o início de vigência nela estipulada”, condicionando o início de vigência a entrega de bens materiais no canteiro e ficando a descoberto o período em que ele acha em preparação e (ii) “que a responsabilidade da Seguradora cessará em relação ao conjunto segurado, ou parte dele, logo que termine o prazo de vigência da apólice, ou durante a sua vigência, assim que se verifique o primeiro dos seguintes casos: (a) tenha sido aceito, mesmo que provisoriamente, por outra entidade que não o Segurado; (b) seja colocado em uso, ainda que em apoio ao projeto segurado; (c) tenha sido efetuada a transmissão de propriedade e (d) de qualquer modo tenha terminado a responsabilidade do Segurado sobre os bens segurados.”, fazendo assim desaparecer a regra básica antes fixada no art. $2^{\circ}$ da Circular IRB PRESI-030/74, o qual dispunha que "[o] prazo do seguro deverá coincidir com o período integral de duração da obra civil ou de montagem."

Ao invés de ser imperativa, como o mencionado art. $2^{\circ}$ da IRB PRESI-030/74, dizendo que a duração da garantia deve coincidir coma duração da obra, a Circular SUSEP n. 016/83 traz dispositivo cuja clareza não é suficiente para evitar polêmicas sobre ser, ou não, compulsória a prorrogação do seguro pela seguradora, quando o segurado solicitá-la, mas, no entanto, clara o suficiente para assentar que o prêmio devido pela prorrogação não mais será aquele resultante da taxa aplicada originalmente, quando da contratação do seguro, mas novo prêmio fixado pela seguradora, o que, evidentemente resulta em detrimento dos interesses dos segurados e beneficiários: "3 - sempre que o prazo de vigência da apólice não tiver sido suficiente, para a conclusão da obra, o Segurado poderá solicitar sua prorrogação a qual será concedida mediante pagamento de prêmio adicional a ser estabelecido de acordo com as disposições tarifárias então vigentes, atualizados os dados constantes da ficha de informações.

Nos anos que se seguiram, especialmente após o advento da democracia, o mercado brasileiro de seguros assistiu a paulatina desmobilização do $\operatorname{IRB}^{297}$ período no qual o ressegurador monopolista passou a atuar na prática como intermediário privilegiado das colocações de resseguro, disponibilizando para os interesses dos retrocessionários a

\footnotetext{
${ }^{297}$ BERCOVICI, Gilberto. "IRB - Brasil Resseguros S.A. Sociedade de Economia Mista. Monopólio de Fato, Dever de Contratar e Proteção à Ordem Pública Econômica”. RDE. Revista de Direito do Estado, v. 12, p. 335-376, 2008: "Com a promulgação da Lei n. 9.482, de 13 de agosto de 1997, que renomeou o IRB para Brasil Resseguros S.A. e dispôs sobre a abertura do seu capital social, foi reafirmada sua natureza jurídica de sociedade de economia mista. Esta lei foi editada no contexto da quebra do monopólio constitucional do IRB no setor de resseguros, por meio da alteração do artigo 192, II da Constituição de 1988 pela Emenda Constitucional n. 13, de 21 de agosto de 1996, e, posteriormente, com a edição da Lei Complementar n. 126, de 15 de janeiro de 2007, que passou a permitir a atuação de resseguradores estrangeiros no país, embora mantendo o IRB como ressegurador local (artigo 22).”
} 
autoridade de plenipotenciário instrumento da política de governo que lhe conferiam as competências fixadas no art. 44 do Decreto-lei n. 73, de 21 de novembro de 1966.

Como visto, a Lei Complementar n. 126, de 15 de janeiro de 2007 dispôs sobre a extinção do monopólio de resseguro, encerrando a política desenvolvimentista planejada que implantara o monopólio. A lei entraria em vigor no ano seguinte, com a regulamentação nela prevista. ${ }^{298}$.

Justamente no apagar das luzes do monopólio, valendo-se da competência normativa que detinha, a sociedade de economia mista IRB Brasil Resseguros S.A., no dia 18 de dezembro de 2007, expediu a norma SEREG - 2428/2007, instituindo um "Novo Clausulado de Riscos de Engenharia" a ser utilizado obrigatoriamente nas operações de seguros de riscos de engenharia no país.

Com o evidente objetivo de impor a coisificação do seguro, eliminado as potencialidades abertas para os segurados e beneficiários pela teoria do interesse que, como vimos, revela que o seguro não garante as coisas, os créditos, as pessoas, mas os interesses que projetam, o IRB acolheu a expressão tangible property, utilizada no direito de ascendência inglesa.

\footnotetext{
${ }^{298}$ Acórdão do Tribunal de Justiça do Estado do Rio de Janeiro proferido em 05.11.2009 no agravo de instrumento $\mathrm{n}^{\circ}$ 2008.002.11982, agravante o IRB Brasil Resseguros S.A. e agravada a Companhia Siderúrgica Nacional, Relator o Des. Fernando FOCH, reconhece persistir o monopólio de fato em fevereiro de 2008. Recente decisão do Magistrado André Augusto SALVADOR BEZERRA, da 42 ${ }^{\mathrm{a}}$ Vara Cível do Foro Central da Capital do Estado de São Paulo, nos autos do processo de rito ordinário n. 021311870.2011.8.26.0100 (583.00.2011.213118), pertinente a ação condenatória proposta por Companhia Siderúrgica Nacional e Nacional Minérios S.A. contra Sul América Companhia Nacional de Seguros e IRB Brasil Resseguros S.A., decidindo questão preliminar de ilegitimidade passiva arguida pelo corréu IRB Brasil Resseguros S. A. entendeu que o monopólio foi extinto com a publicação da Resolução SUSEP n. 168 de 17 de dezembro de 2007, publicação essa feita no dia 19 de do mesmo mês e retificada no dia 10 de janeiro de 2008: "Nesse aspecto, verifico que a Lei Complementar 126 de 15 de Janeiro de 2007 abriu o mercado brasileiro de resseguros, colocando fim ao monopólio até então exercido pela ré. Diante da data da apólice em questão (fls. 275), o mencionado diploma legal é aplicável ao caso, o qual entrou em vigor na data de sua publicação. Ocorre que, ao contrário do que defende a requerida, à época da confecção da apólice, as atividades concernentes ao novo mercado de resseguros ainda não haviam sido regulamentadas. Isto só veio a ocorrer com a Resolução de n. 168 da SUSEP, publicada no mês de Dezembro do mesmo ano, portanto, depois que a apólice foi confeccionada, derrubando por terra os argumentos articulados em resposta referentes à ilegitimidade passiva." Para BERCOVICI o monopólio legal vigorou até a edição da Portaria SUSEP n. 2.886, de 25 de março de 2008. BERCOVICI, Gilberto. "IRB - Brasil Resseguros S.A. Sociedade de Economia Mista. Monopólio de Fato, Dever de Contratar e Proteção à Ordem Pública Econômica". RDE. Revista de Direito do Estado, v. 12, p. 335-376, 2008: “A Lei n. 8.884/1994, é expressa, em seu artigo 15, ao determinar sua aplicação às pessoas físicas ou jurídicas de direito público ou privado, mesmo que exerçam atividade sob regime de monopólio legal. Em princípio, portanto, a Lei n. 8.884/1994 se aplicaria a uma sociedade de economia mista, mesmo exercendo o monopólio legal, como o IRB exerceu sobre o setor de resseguros, constitucionalmente, até o advento da Emenda Constitucional n. 13/1996, e, legalmente, até a edição da Lei Complementar n. 126/2007, do cumprimento do prazo de 120 (cento e vinte) dias fixado pela Resolução CNSP (Conselho Nacional de Seguros Privados) n. 168, de 17 de dezembro de 2007, e da edição da Portaria SUSEP n. 2.886, de 25 de março de 2008, que cadastrou o primeiro ressegurador eventual no Brasil que não o IRB."
} 
Nos anos 2000, durante regulações de sinistro em que a expressão estrangeira, traduzida ao pé da letra para propriedade tangível, sofreu crítica por não constituir terminologia apta para gerar as pretendidas limitações de conteúdo do seguro, diante da regra do art. 423 do Código Civil ${ }^{299}$, as apólices passaram a conter, a palavra coisa que em nossa língua e no nosso direito tem o significado corpóreo desejado, sem o abandono da presença, nos clausulados da expressão forasteira que certamente os resseguradores estrangeiros encareceram não fosse suprimida das apólices das seguradoras brasileiras.

Assim, a norma do IRB na sua primeira cláusula apresenta um glossário para esclarecer o que é dano físico:

\section{Cláusula $1^{\text {a }}$ - Glossário}

Dano físico - é aquele que atinge a propriedade tangível (coisas)

A disposição seguinte, "Cláusula $2^{\mathrm{a}}$ - Objeto do Seguro", fere de morte as potencialidades da doutrina do interesse, teoria incorporada por nosso direito positivo, na regra do art. 757 do Código Civil, entre outras, além corresponder às práticas de hermenêutica do seguro, e à cultura de regulação e liquidação de sinistros. Há décadas se compreendia que o sinistro era a lesão ao interesse pertinente aos bem e não pressupunha necessariamente sua avaria.

A norma posta pelo IRB, contudo, dispõe que o "seguro tem por finalidade garantir interesse legítimo do Segurado, (...) contra danos físicos à propriedade tangível (coisas seguradas)." As perdas acidentais de utilidade e funcionalidade de um bem, mesmo absolutas, deixam de estar garantidas pelo seguro, a menos que coisa abrangida pelo seguro sofra dano físico. Outros dispositivos reforçam o empenho depressor da garantia disposto na cláusula $2^{\mathrm{a} 300}$

Além disso, a norma restringe a garantia para os prejuízos decorrentes de danos físicos que tenham ocorrido durante a vigência do seguro, o que também deprime a garantia à medida que muitas vezes a causa do dano acontece durante a vigência do seguro

\footnotetext{
${ }^{299}$ Art. 423. Quando houver no contrato de adesão cláusulas ambíguas ou contraditórias, dever-se-á adotar a interpretação mais favorável ao aderente.

${ }^{300}$ Cláusula $8^{\mathrm{a}}$ - Cálculo da indenização

8.1 - A indenização corresponderá ao custo dos reparos ou reposição das coisas já instaladas, construídas ou montadas, incluídas despesas aduaneiras e de transporte, desmontagem e remontagem, que tenham sido danificadas fisicamente, de modo a repô-las no estado em que se encontravam imediatamente antes do sinistro, acrescido, se for o caso, dos valores correspondentes às coberturas adicionais contratadas menos o valor de salvados, quando couber, e deduzindo-se do valor então obtido a participação do Segurado em consequência do rateio, se houver, deduzindo-se, em seguida, a franquia.

(...)

8.3 - Em nenhuma hipótese, a indenização compreenderá o valor dos danos físicos que excederem ao valor das coisas individualmente danificadas na data do sinistro.
} 
e o dano em si surge somente depois de haver terminado a garantia, sendo corrente na doutrina jurídica securitária o reconhecimento de que o sinistro inicia com a causa e deve ser indenizado. Exemplificativamente, o IRB já havia indenizado prejuízos causados em sinistros de incêndio em situações nas quais a ignição foi iniciada antes da meia noite, quando se encerraria a vigência do seguro, e a combustão sobreveio quando já se havia encerrado a vigência. Na infortunística da engenharia é bastante comum, senão predominante, a manifestação tardia dos danos causados por erros de projeto ou de construção precedentes.

Veja-se a disposição que instaura a coisificação do seguro de construção no Brasil:

Cláusula $2^{\text {a }}$ - Objeto do Seguro

$\mathrm{O}$ presente seguro tem por finalidade garantir interesse legítimo do Segurado, até o Limite Máximo de Garantia da Apólice ou o Limite Máximo de Garantia por Cobertura Adicional, constante na especificação da Apólice, contra danos físicos à propriedade tangível (coisas seguradas) que o Segurado venha a sofrer, somente durante a vigência da apólice, em consequência de riscos cobertos, enquanto permanecerem inalterados os dados constantes da proposta de seguro, da ficha de informações, do contrato de construção civil, instalação e montagem e outros documentos juntados, dados esses que serviram de base à emissão da Apólice, da qual os documentos antes citados passam a fazer parte integrante.

O declínio do conteúdo dos contratos de seguro de riscos de engenharia promovidos pelo IRB prossegue para evitar que a seguradora deva garantir, como outrora, todo o período demandado para a conclusão da obra, a exemplo do que dispunha a Circular PRESI-030/74 no art. $2^{\circ}$ : “[o] prazo do seguro deverá coincidir com o período integral de duração da obra civil ou de montagem.” Já não satisfazia a regra da Circular SUSEP n. 016/83, pois embora garantisse às seguradoras discricionariedade para decidir sobre o valor do prêmio adicional, havia fundamentado decisões judicias que impunham a prorrogação.

A SEREG 2428/2007 dispôs sobre as prorrogações tornando-as burocráticas, instituindo para as mesmas um procedimento mais complexo do que o pertinente à aceitação de seguros novos.

No princípio a vigência abrangente era obrigatória, como dispunha a Circular PRESI-030/74, depois se tornou necessário solicitar a prorrogação, nos termos da Circular SUSEP n. 016/83.

Agora o pedido deve ser formal, está sujeito a um complexo regime de declarações e a prorrogação poderá ou não ser acatada pela seguradora, a qual fixará discricionariamente o prêmio para o período prorrogado e, finalmente, poderá ser inovado, 
a critério exclusivo da seguradora, o conteúdo da garantia. ${ }^{301}$ A preocupação do IRB em travar as prorrogações é tanta que a normativa contém mais uma regra no mesmo sentido: “19.3 - Se o prazo do seguro não for suficiente, o Segurado poderá solicitar a prorrogação, que poderá ou não ser concedida, aplicando-se, na hipótese, o disposto na cláusula $7^{\mathrm{a}}$ destas Condições Gerais.”

A norma do IRB também coisifica e transforma em indenizações contratuais o dever de reembolsar as despesas de salvamento, que a lei impõe para as seguradoras. ${ }^{302}$

Outra redução relevante é feita com a adição do adjetivo "parcial" para expressar que a colocação em uso e a aceitação da obra determinadoras da liberação da responsabilidade da seguradora não necessitam ser de toda a obra, bastando parte dela.

Além disso, tomando-se por base a Circular SUSEP n. 016/83, é acrescido um novo e amplíssimo fator de liberação: “assim que o prazo se esgote, definido no cronograma de

${ }^{301}$ Cláusula $7^{\mathrm{a}}$ - Modificação e prorrogação do seguro

7.1 - A prorrogação ou a modificação do seguro será feita mediante proposta de seguro assinada pelo proponente, por seu representante legal ou por corretor habilitado e entregue sob o protocolo fornecido pela Seguradora.

7.2 - A aceitação da prorrogação, bem como da modificação, estarão sujeitas à análise prévia do risco pela Seguradora, a qual poderá solicitar informações e documentos complementares àqueles inicialmente indicados na proposta.

7.3 - Na hipótese de não aceitação da proposta de seguro, pertinente à prorrogação ou à modificação, a Seguradora fará comunicação formal ao proponente, apresentando a justificativa da recusa.

7.4 - Sempre que o prazo de vigência da Apólice não tiver sido suficiente para a conclusão da obra civil ou da instalação/montagem, o Segurado poderá solicitar sua prorrogação, com antecedência mínima de 30 (trinta) dias antes do término da vigência, a qual poderá ou não ser concedida.

7.5 - A concessão da prorrogação dependerá do exame das justificativas para sua solicitação, da atualização dos dados constantes da ficha de informações e outros documentos que deram origem ao seguro contratado e demais documentos necessários à análise do pedido. Se concedida a prorrogação, será estipulado o pagamento de um prêmio adicional a ser estabelecido de acordo com o estado do risco segurado na época do pedido. Termos e condições originais da apólice poderão ser revisados pela Seguradora, em função do exame que ela realizará. Se a necessidade de prorrogação ocorrer por motivo de sinistro, o prêmio a ser cobrado não poderá, em nenhuma circunstância, ser recuperado pelo Segurado como prejuízo indenizável.

9.4 - Sempre que o prazo de vigência da Apólice não tiver sido suficiente para a conclusão da obra civil ou da instalação/montagem, o Segurado poderá solicitar sua prorrogação, com antecedência mínima de 30 (trinta) dias antes do término da vigência, a qual poderá ou não ser concedida.

9.5 - A concessão da prorrogação dependerá do exame das justificativas para sua solicitação, da atualização dos dados constantes da ficha de informações e outros documentos que deram origem ao seguro contratado e demais documentos necessários à análise do pedido. Se concedida a prorrogação, será estipulado o pagamento de um prêmio adicional a ser estabelecido de acordo com o estado do risco segurado na época do pedido. Termos e condições originais da apólice poderão ser revisados pela Seguradora, em função do exame que

ela realizará. Se a necessidade de prorrogação ocorrer por motivo de sinistro, o prêmio adicional a ser cobrado não poderá, em nenhuma circunstância, ser recuperado pelo Segurado como prejuízo indenizável.

3024.1 - São indenizáveis, até o Limite Máximo de Garantia da apólice ou até o Limite Máximo de Garantia por Cobertura Adicional contratado, estipulado na especificação da apólice, obedecidos os exatos termos e condições do presente contrato de seguro, os seguintes itens:

I. danos físicos, diretamente resultantes dos riscos cobertos, que venham a sofrer as coisas seguradas;

II. eventuais encargos de tradução referentes ao reembolso de despesas efetuadas no exterior;

III. danos físicos e/ou despesas incorridas para evitar o sinistro ou minimizar seus efeitos. 
eventos submetido à Seguradora, pertinente ao conjunto de atividades envolvendo a coisa segurada."

O regime instituído pelo IRB em 2007 não é alterado com a edição da CIRCULAR SUSEP N. 419 DE 17.01.2011, não obstante possa flexibilizar a interpretação do seguro em razão do abandono da expressão dano físico que é substituída por "prejuízos materiais às máquinas, equipamentos, estruturas metálicas e a outros bens instalados e/ou montados de forma permanente durante a fase de instalação e/ou montagem destes bens".

A captura ideológica ocorrida na agência estatal migra para os demais órgãos de governo e acaba por prejudicar até mesmo as iniciativas destinadas a instrumentar novamente o país diante da extinção do monopólio de resseguro e da perda de capacidades sofrida pelo mercado. Prova disto é a já mencionada regra do artigo 28 da Medida Provisória n. 564/2012, convertida na Lei n. 12.712, de 30 de agosto de 2012, que autorizou a criação da Agência Brasileira Gestora de Fundos e Garantias S.A. - ABGF, pois retringe as garantias a serem prestadas pela mesma aos danos físicos:

“Art. 28. A ABGF terá por objeto:

I - a concessão de garantias contra riscos:

(...)

b) de danos físicos ao imóvel - DFI, em operações de crédito habitacional no âmbito de programas ou instituições oficiais;

Segue comparativo entre seguro para obra de Metrô da Inglaterra, país central, e o mesmo seguro no Egito, país de periferia. O conteúdo dos seguros de risco de engenharia no Brasil acercava-se do primeiro grupo e foi reconduzido ao segundo em 2007:

\begin{tabular}{|c|c|}
\hline Londres & Cairo \\
\hline $\begin{array}{l}\text { Interest: The interest insured by this } \\
\text { Policy includes all } \\
\text { (i) activities associated with the } \\
\text { Insured Programme } \\
\text { commencing during the Period } \\
\text { of Insurance (or prior thereto } \\
\text { with approval of Insurers) } \\
\text { including all associated and } \\
\text { ancillary works connected } \\
\text { therewith and all activities and } \\
\text { operations forming part of the } \\
\text { Insured Programme. } \\
\text { Liabilities towards third parties } \\
\text { arising form (i) above. }\end{array}$ & $\begin{array}{l}\text { Interest } \\
\text { To identify the Insured in respect of a } \\
\text { physical loss of or material damage to the } \\
\text { Tunnelling Boring Machine named } \\
\text { CLEOPATRA occurring during the period } \\
\text { of insurance arising from the erection, } \\
\text { disassembling, testing commissioning } \\
\text { whatsoever as hereinafter. } \\
\text { - Erection, testing and } \\
\text { commmissioning near Abbasia } \\
\text { shaft } \\
\text { - Dismantling near Abbasia shaft } \\
\text { - Loading and unloading of the } \\
\text { TBM into Abbasia shaft, erection, } \\
\text { testing and commissioning }\end{array}$ \\
\hline
\end{tabular}


Embora o Brasil também contasse com praxe estável e inclusive dispusesse de norma administrativa garantindo que as prorrogações necessárias seriam concedidas mediante a mera solicitação dos segurados, a nova normativa do IRB incorporou padrões que vinham sendo buscados pelos resseguradores estrangeiros em atividade no país, ainda enquanto retrocessionários do monopolista, no sentido de bloquear as prorrogações e tornálas mais complexas do que as próprias assunções originais de ricos. Isso vem na contramão da experiência nacional, como da conjuntura especial de demanda por infraestrutura que o país vive.

Há uma evidente contradição entre os anseios do setor ressegurador e a orientação da Constituição Federal de 1988 que reflete na conformação da cultura jurídica securitária brasileira, a exigir medidas urgentes para a garantia da melhora dos conteúdos dos contratos de seguro e da consciência jurídica que lhes atribui significado, como bem adverte o Conselho Admnistrativo de Defesa Econômica:

6.16. A redemocratização do Brasil trouxe ao texto constitucional pautas que buscavam contrariar o espírito do tempo anterior, o que pode ser encontrado em inúmeros trechos do diploma, sendo marcantes os comandos com caráter redistributivo do artigo $3^{\circ}$. (que buscam dar uma resposta a um modelo econômico extremamente concentrador) e com caráter de soberania econômica (resposta a uma economia altamente internacionalizada a partir da vinda das automobilísticas e da indústria química, sob a égide da politica de alinhamento - alguma vez tensa com os Estados Unidos). Nesse sentido, a dicção do artigo 192 estabelecia que "o sistema financeiro nacional, estruturado de forma a promover o desenvolvimento equilibrado do País e a servir aos interesses da coletividade, será regulado por Lei Complementar que disporá, inclusive, sobre (...) autorização e funcionamento dos estabelecimentos de seguro, previdência e capitalização, bem como do órgão oficial ressegurador", que veio a ser substituído por "órgão oficial fiscalizador", até a última emenda, de 2003, torná-lo cláusula mais geral e abrangente (mas mantendo sua subordinação aos objetivos de "promoção do desenvolvimento"), segundo a qual "o sistema financeiro nacional, estruturado de forma a promover o desenvolvimento equilibrado do País e a servir aos interesses da coletividade, em todas as partes que o compõem, abrangendo as cooperativas de crédito, será regulado por leis complementares que disporão, inclusive, sobre a participação do capital estrangeiro nas instituições que o integram.

6.17. Dessa maneira, toda regulação infra-constitucional sobre seguro, quer seja a regulação que determine os termos do contrato, a atuação da empresa ou a conformação do mercado, está submetida à pauta simultânea dos artigos $3^{\circ}, 219$ e 192, entre outros, de nossa Constituição, que instrumentalizam a superação do estado de subdesenvolvimento, isto é, os valores da distribuição de recursos em uma sociedade estruturalmente desigual e da defesa do "mercado interno 
como patrimônio nacional, vertido ao bem-estar da população, seu desenvolvimento cultural e a autonomia tecnológica do país.

6.18. Para ser um instrumento na busca desse fim, como o determina o texto Constitucional, o seguro não pode estruturar-se como mero jogo e aposta, em bases individualistas (que, se funcionam algumas vezes, não apresentam certeza sistêmica de continuidade). Para que os fins constitucionais sejam alcançados, toda a técnica e teoria acima descritas (advinda dos profundos avanços matemáticos, estatísticos e atuariais) resta funcionalizada à construção de um verdadeiro sistema orgânico de controle estatal (...)".303

Se outrora o Brasil perseguiu evitar a evasão de divisas, com isso se justificando o mais estrito controle da atividade seguradora e resseguradora, hoje o problema é, fundamentalmente, evitar o esvaziamento dos conteúdos dos contratos de seguro conquistado ao longo de décadas, especialmente dos seguros de riscos relacionados com as obras necessárias para o desenvolvimento econômico e social do país.

Essa delicada questão não se encontra numa problemática restrita ao país. Em Portugal, João Calvão da SILVA identifica esse mesmo movimento e enfatiza a necessidade de uma intervenção estatal mais atenta,

Neste tempo crescentemente financeirizado, em ordem a evitar o triunfo de um metacapitalismo financeiro selvagem, um capitalismo financeiro e apátrida extremamente desigual e injusto, à procura da (...) terra prometida, mais forte que os Estados ou regulador principal dos Estados e sociedades, indiferente aos custos econômicos, sociais, culturais e morais. ${ }^{304}$

O problema torna-se crítico quando a intervenção estatal passa a caracterizar-se como um "novo estado de regulação", ou "capitalismo de regulação", isto é, quando o setor público incorpora um modo de pensar bastante similar ao empresarial e a "ética pública" se vê sucedida por "critérios de empresa", onde o objetivo de eficiência deixa sua dimensão política, para assumir gradativamente uma dimensão igual àquela que exigiu a intervenção. Isso esgarça a ação desmedida e incontrolável do metacapitalismo financeiro e apátrida à busca da terra de ninguém. ${ }^{305}$

303 CONSELHO ADMINISTRATIVO DE DEFESA ECONÔMICA. Ato de Concentração n ${ }^{\circ}$ 08012.005526/2010-39. Requerentes: Banco do Brasil S.A., BB Seguros Participações S.A. e Mapfre Vera Cruz. Relator Alessandro Luis S. Octavini. Voto publicado no Diário Oficial da União de 10.02.2012 n. ${ }^{\circ} 30$, Seção 1, páginas 44, 45 e 46, p. 8-9.

304 "Globalização e direito da banca, da bolsa e dos seguros: uma resposta européia". In: Boletim STVDIA IURIDICA, n ${ }^{\circ} 73$ Coimbra Editora, Boletim da Faculdade de Direito, Stvdia ivridica, 2003.

${ }^{305}$ SHEARING, Clifford e WOOD, Jennifer. Imagining Security. Cullompton: Willan Publishing, 2007, p. 152. 
Essa curva ascendente de deterioração da consciência a respeito dos fins da intervenção estatal, a confusão entre o ser Estado e o ser empresa ganha destaque, ainda mais especial, quando lembramos com Pablo González CASANOVA que

os dirigentes governamentais conhecem as ameaças de uma 'sociedade insustentável' e de um 'mundo ingovernável', mas sua 'vontade de conhecer' se reduz à busca de uma 'sociedade sustentável' e de uma 'governabilidade melhorada' que não afetem um só de seus interesses imediatos e particulares. ${ }^{306}$

A evidenciar o risco que sofre a segurança da nossa ordem econômica está o fenômeno da recepção das ordens jurídicas globais ou hegemônicas pelos sistemas jurídicos dos países em desenvolvimento. A recepção de regras jurídicas moldadas em outros ambientes tende a significar a absorção de ideias de um sistema cultural e economicamente distinto, disfuncionais para o sistema jurídico receptor.

Os países localizados na periferia do capitalismo, onde, apesar de períodos de aceleração ou crescimento econômico, o quadro de subdesenvolvimento remanesce, vivem um estado econômico de exceção permanente onde coadjuvam o

decisionismo de emergência para salvar os mercados com o funcionamento dos poderes constitucionais, bem como a subordinação do Estado ao mercado, com a adaptação do direito interno às necessidades do capital financeiro, exigindo cada vez mais flexibilidade para reduzir as possibilidades de interferência da soberania popular. 'A razão de mercado passa a ser a nova razão de Estado', ${ }^{307}$

Apesar de ser evidente que os conteúdos dos seguros empresariais são predeterminados pelos resseguradores, e que as empresas de maior envergadura não conseguem atingir grau minimamente relevante de intervenção para a formulação desses conteúdos, o atual superintendente da SUSEP, em depoimento à Câmara dos Deputados, no dia 31 de outubro de 2012, chega a propor que os grandes segurados brasileiros estipulam livremente o conteúdo dos seguros com os resseguradores internacionais, uma crença que não se verifica em canto algum da realidade seguradora mundial, onde as próprias companhias de seguro, muitas vezes, especialmente nos grandes riscos, não logram intervir nas disposições essenciais do clausulado que lhes são impostos pelos resseguradores.

${ }^{306}$ CASANOVA, Pablo González. O colonialismo global e a democracia. Rio de Janeiro: Civilização Brasileira, 1995.

${ }^{307}$ BERCOVICI, Gilberto. O Estado de exceção econômico e a periferia do capitalismo. Disponível em $\langle$ http://www.unicamp.br/nee/epremissas/pdfs/2/03.02.pdf> . Acesso em 01 de julho de 2011. 
O momento vivido pelos contratos securitários brasileiros nas duas décadas caracteriza fase de desconstrução dos avanços do desenvolvimentismo, o que se dá com a incursão e prevalência de determinadas más práticas forasteiras e a replicação deste mesmo comportamento pelos seguradores locais e pelos agentes do Estado.

Apesar da grande expectativa com o Código Civil, a real contribuição do diploma de 2002 para o desenvolvimento do regramento positivo do nosso direito securitário foi bastante restrita, talvez merecendo menção exclusivamente as regras que assentam a chamada teoria do interesse.

Típico texto oitocentista, remodelado ao longo dos anos 1960 com base em questões já amadurecidas no Supremo Tribunal Federal depois de morosos processos judiciais e sem merecer qualquer debate significativo ao longo da tramitação, o capítulo do Código dedicado ao contrato de seguro trouxe normas que já não mais refletiam o estágio de desenvolvimento das operações de seguros no país e, na verdade, com linguagem completamente avessa às novidades trazidas na parte geral do direito das obrigações.

Seu artigo 758 diz que o contrato de seguro é provado por meio da apólice, do bilhete do seguro e, na falta desses documentos, pelo recibo de pagamento do respectivo prêmio. Alguns autores, estarrecidos, identificaram, aí o restabelecimento do já abandonado regime da prova legal. De qualquer modo, independentemente de se concluir que não se trata de prova legal, a norma se mostra contrária à realidade, seja porque o seguro é consensual, e algumas vezes seu documento típico deixa de ser emitido pela seguradora, seja porque quase invariavelmente a emissão do documento é feita muito depois de iniciada a vigência do contrato, seja porque o pagamento do prêmio é ato de execução que devido a inúmeras razões pode ser diferido no tempo.

O artigo 759 estabelece que "a apólice deverá ser precedida de proposta escrita", quando inúmeros seguros são celebrados diante da simples adoção de comportamentos sociais típicos, uso de cartão de crédito, meios eletrônicos diversos etc., nem sempre havendo proposta escrita.

O artigo 783 recupera como regra a cláusula de rateio em sinistros parciais, solução que, como já mencionamos, havia trazido muita polêmica, ao longo de décadas, e fora praticamente abandonada nos seguros em geral, transformando-se em exceção. Visando à pacificação das relações securitárias, o rateio fora reservado para os seguros empresariais de maior porte. O Código, preocupado com as questões nevrálgicas dos anos 1960, acabou por reincorporar a polêmica. 
São muitos os exemplos de regras antiquadas e de lacunas normativas postas pelo Código Civil de 2002 diante do grande desenvolvimento das operações de seguro no Brasil.

Apesar disso, o novo Código compôs-se contundentemente com a teoria do interesse, o que oferece ao jurista um importante instrumento para combater o progressivo emagrecimento das coberturas de seguro de danos, que se vem "coisificando", progressivamente, como visto, com amparo, ainda que despercebido, das práticas governamentais (SUSEP, IRB, Medida Provisória n. 564/2012 ${ }^{308}$ etc.).

Com a abertura do resseguro e o IRB atuando como um ressegurador típico, sem cometimentos estatais, os conteúdos pioraram, as regulações de sinistro são comandadas por agentes sem afinidade cultural alguma com o país, e a própria subscrição de riscos tornou-se mais restritiva, revelando fenômeno chamado "risco declinável", antes desconhecido entre nós, uma vez que o IRB sempre fora obrigado a recepcionar todos os riscos, exceto os tecnicamente não asseguráveis ou contrários ao interesse nacional. ${ }^{309}$

No setor de seguros o desrespeito à ordem econômica não tem origem exclusivamente no comportamento dos seguradores, resseguradores, corretores, agentes e reguladores de sinistro. Há infrações ocasionalmente cometidas também por compradores de seguro, geralmente envolvendo casos de fraude, e a trilogia do Genesis se completa com os abusos originados a partir da própria atividade estatal, ou seja, a partir do próprio Estado intervencionista, como ocorreu com a sociedade de economia mista IRB, especialmente entre os anos 1990 até a sua recente privatização, e com a autarquia federal fiscalizadora SUSEP.

Ao invés de avançar linearmente no sentido da proteção dos consumidores e da amplificação do acesso da sociedade ao seguro, o Estado brasileiro contribui para lesar a ordem econômica securitária, deprimindo os direitos dos consumidores, propiciando a exclusão ao acesso ao serviço securitário ou a redução de seu proveito integral, de forma tão particularmente importante que confirma a velha definição de soberania como o direito de excluir. ${ }^{310}$

\footnotetext{
${ }^{308}$ Hoje convertida na Lei n. $12.712 / 2012$.

${ }^{309}$ Art. 44, Alínea d do Decreto Lei n. 73/66, parcialmente revogado pela Lei Complementar n. 126/2007: "Art. 44. Compete ao IRB: (...) b) aceitar o resseguro".

310 TZIRULNIK, Ernesto. Direito ao seguro privado: discriminação e ação afirmativa in Tratado LusoBrasileiro da Dignidade Humana, MIRANDA, Jorge e SILVA, Marco A. Marques da (coord.), São Paulo, Quartier Latin, 2008.
} 
Se os principais motivos são os interesses dos conglomerados financeiros capitalistas que empreendem a atividade econômica securitária e a captura da Administração, o salvo conduto será a verdadeira caixa de pandora em que consiste esse negócio transindividual jamais vivido pelos gregos, nem pelos romanos, avesso à idéia de bilateralidade e liberdade de conteúdo.

Escoltado pela espada da estatística e da atuária, o fenômeno securitário será acessível tão somente para os iniciados no quase idioleto "segurês", que se forma a partir de argumentos pseudo complexos do ponto de vista técnico.

O tecnicismo propiciará a exclusão desafiadora do direito do consumo, como adverte Pierre BOURDIEU: “[t]alvez não haja pior privação, pior carência, que a dos perdedores na luta simbólica por reconhecimento, por acesso a uma existência socialmente reconhecida, em suma, por humanidade. ${ }^{311 \text {, }}$

Com toda segurança não há qualquer exagero em afirmar que a recusa de acesso às garantias possíveis e a exclusão do sistema e dos proveitos comuns da proteção securitária lesarão cada indivíduo para além da sua condição de consumidor, chegando à própria pessoa. $^{312}$

A depressão do conteúdo e o afunilamento do acesso ao seguro constituem, na sociedade atual, uma face terrível da discriminação, especialmente se considerarmos a impossibilidade de enfrentamento individual para os efeitos da infortunística, o que já vimos ser tarefa inglória na sociedade contemporânea.

Não podemos esperar que políticas de socialidade salvadoras do atual estado de coisas na sociedade, ante o desbragado liberalismo financeiro, provenham no horizonte empresarial dos seguradores e demais empresários do setor, pois como lembra André COMTE-SPONVILLE, "se quisermos que exista moral numa sociedade capitalista (...), essa moral, como em toda sociedade, só pode vir de outra esfera que não a economia. Não contem com o mercado para ser moral no lugar de vocês!" 313

\footnotetext{
${ }^{311}$ Pierre BOURDIEU, Meditações pascalianas apud Z. BAUMAN, Vida para consumo - a transformação das pessoas em mercadoria, Rio de Janeiro, Zahar, 2008, p. 7.

312 DUSSEL, Enrique, Vivemos uma primavera política in Jornadas Bolivarianas. Disponível em http://www.iela.ufsc.br/?page=noticias_visualizacao\&id=785, acesso em 09 de novembro de 2009: "Há um campo onde o sujeito é intersubjetivo. Temos que partir de um conceito novo de sujeito. Somos intersubjetivos. Nós levamos conosco o nosso pai, a nossa mãe, nossa família, nossa comunidade, e temos de pedir ajuda a Freud para mostrar como o inconsciente é comunitário e intersubjetivo".

${ }^{313}$ COMTE-SPONVILLE, André. O capitalismo é moral?, São Paulo, Martins Fontes, 2005, p. 79.
} 
Essa missão moralizadora cabe ao Direito e à prática daqueles que o operam na sociedade, valendo notar com Jason J. KILBORN que até mesmo os legisladores acabam atirando os consumidores no "oceano repleto de tubarões". 314

Assim, foi "não curioso" ler a notícia de que o a sociedade de economia mista brasileira monopolista do resseguro deixaria de ser engajada com o desenvolvimento econômico e passaria a atuar agressivamente como é esperado da típica empresa privada. A idéia de pujança na atividade econômica saíra da política da geração de qualidades para a busca de lucratividade, daí resultando a "agressividade". Sucesso empresarial e agressividade não à toa se unem cada dia mais. Hoje os executivos são elogiados como galos de rinha. Têm mais valor os agressivos do que os não agressivos. E danos, é bom lembrar, são os efeitos próprios das agressões. ${ }^{315}$

314 KILBORN, Jason J. Comportamentos econômicos, superendividamento; estudo comparado da insolvência do consumidor: buscando as causas e avaliando as soluções? Estudos de Direito Comparado sobre o superendividamento in Direitos do Consumidor Endividado. LIMA MARQUES, Cláudia e LUNARDELLI CAVALLAZZI, Rosângela (coord.), São Paulo, Revista dos Tribunais, 2006, p. 79.

315 "O IRB-Brasil Resseguros pretende entrar em 2010 com um perfil mais agressivo de atuação. Com a ajuda da Boston Consulting Group (BCG), a ex-estatal de 70 anos, ex-monopolista da atividade de resseguros no país, reestruturou suas operações para enfrentar a nova fase da abertura de mercado, quando perderá parte da preferência que ainda tem na contratação de coberturas no país.

Desde que a liberalização do mercado começou, em 2008, o IRB perdeu $30 \%$ do mercado ressegurador doméstico. De acordo com as regras de abertura, a partir de janeiro do próximo ano as seguradoras deverão passar preferencialmente pelo IRB uma fatia de $40 \%$ de seus negócios que exigem resseguros. Até agora esse percentual era de $60 \%$.

A estratégia delineada com o auxílio do BCG é baseada em três pilares: uma nova diretoria comercial, seleção dos riscos mais rentáveis e aumento da capacidade de cobertura de resseguros no exterior, contou Eduardo Nakao, presidente da instituição. Recomendações como proatividade comercial e rentabilidade das operações soam básicas para qualquer companhia privada, mas no caso do IRB buscam combater vícios dos tempos em que a empresa era uma estatal monopolista. (...) "A primeira constatação é que o IRB precisava se aproximar dos clientes e dispor de uma capacidade de colocação de riscos no exterior em substituição à capacidade que passou a ser oferecida pelos resseguradores que decidiram atuar como empresas locais no Brasil", afirmou Nakao sobre o trabalho da BCG.

Enquanto foi monopolista, (...). A capacidade de colocação de riscos no mercado internacional era garantida, não por esforço próprio, mas pela atuação das empresas internacionais, que colocavam seu próprio capital à disposição do IRB, em troca de participar da rentabilidade proporcionada pelos negócios que envolviam risco Brasil. (...) Agora a equação se inverteu. As resseguradoras podem se instalar no Brasil e operar diretamente com as seguradoras brasileiras, sem passar pela ex-estatal. Para o patrimônio de $\mathrm{R} \$ 1,9$ bilhão, o IRB tem um limite de aceitação de riscos de $\mathrm{R} \$ 50$ milhões por contrato. A capacidade total de colocação de riscos no exterior é de US\$ 700 milhões. Antes da abertura, entre 2005 e 2006, era de US\$ 565 milhões. A capacidade de colocação de riscos no exterior é a essência do resseguro, que nada mais é que capturar excessos de riscos e diluí-los entre vários outros tomadores. Alguns seguros como os de navios cargueiros ou aviões são insuportáveis para uma única seguradora, às vezes até para um grupo delas. Calcula-se que para um risco de US\$ 500 milhões - valor aproximado pago pela indenização da plataforma P-36 da Petrobras, que afundou em 2001 - são necessárias 60 resseguradoras. (...) Mas as condições de manutenção desta capacidade mudaram muito nos últimos dois anos. Antes as resseguradoras estrangeiras davam ao ex-monopolista brasileiro condições favoráveis de coberturas, preços e prazos. Agora uma das missões do IRB é recuperar essas condições. (...) Como monopolista, o IRB era obrigado a aceitar todo e qualquer risco que necessitasse de resseguro. Na maioria das vezes, repassava a maior parte para o mercado internacional. Eventualmente ficava com uma pequena parcela do contrato, mas nunca poderia aceitar parcialmente um contrato. Agora é diferente, diz Nakao: "tudo será uma questão de cláusula (de contrato), frequência e severidade (de sinistros registrados)". O IRB não quer mais assumir resseguros de eventos naturais (chuva, granizo, furacão etc.) e, 


\subsubsection{Arbitragem e difusão normativa}

Inexistindo lei suficiente para a disciplina da matéria contratual, são incessantemente expelidos verdadeiros jatos regulatórios. Com isso, além do fenômeno da captura das autarquias estatais, facilitado pela dispersão e pela profusão normativas, desparecem as definições jurídicas capazes de orientar a crítica e a conduta dos administrados.

José Menéres PIMENTEL, esforçado em SOUSA FRANCO, lembra que a profusão normativa tem como efeito confundir o conteúdo do Direito, promover o inadimplemento, o arbítrio dos mais poderosos, e impossibilitar a fixação da jurisprudência, essa tão cara construção da experiência social jurídica:

O legislador hodierno é permeável aos interesses existentes na sociedade em vez de conduzir ele próprio as alterações e as mudanças nessa mesma sociedade. Esta instabilidade legislativa levou Sousa Franco no prefácio da última edição das suas lições de Finanças Públicas e Direito Financeiro a falar em "legorreia", ou para ser mais preciso, e cito "em diarreia legislativa". Segundo este professor, esta situação "....mina o Estado de Direito, cria confusão quanto ao que é certo ou errado, justo ou injusto, enfraquece os direitos das pessoas, estimula o arbítrio dos poderosos e o incumprimento dos deveres, impossibilita a fixação da jurisprudência e a certeza de soluções". ${ }^{316}$

Meio à "legorréia", prosperam os confusos e ininteligíveis comandos normativos produzidos nos documentos elaborados pelos seguradores e resseguradores. A criação de um continente dogmático contratual próprio e de jurisdições privadas constituem antigos sonhos do setor securitário, e ressecuritário internacional, como salienta o senador Humberto COSTA, citando Ernest RABEL, ao propor a lei especial de seguro:

A tentativa dos seguradores e resseguradores estrangeiros perseguirem
independência dos direitos e das instituições judiciárias nacionais não é
mera retórica. Isso já era constatado por importante doutrinador da
primeira metade do século XX: "O comércio mundial criou uma incrível
rede de cláusulas, formulários contratuais e termos e condições negociais.

no que depender de Nakao, não haverá mais cobertura para automóveis no pátio das montadoras, onde uma chuva de granizo pode representar milhões de dólares de prejuízo. "Vamos exigir que os automóveis fiquem em garagem coberta. Se aceitarem, bem. Senão, recusamos o contrato." (...) Os ramos prioritários na nova estratégia serão aviação, industriais ("properties"), energia e engenharia. Outros riscos poderão ser aceitos, porém serão olhados com lupa. É o caso dos seguros de responsabilidade civil, um ramo de pouca tradição no Brasil. Nesse caso, o IRB poderá entrar para ficar com uma pequena fatia, apenas para acompanhar o setor, obter informações para formar um banco de dados. "Mas desde que tenha cláusulas muito claras de exclusão de determinados riscos", avisa." Jornal Valor Econômico - 08 de dezembro de 2009 - IRB quer risco rentável Janes Rocha.

${ }^{316}$ PIMENTEL, José Menéres. "Perspectivas para o século XXI". Perspectivas do Direito no início do século XXI. Coimbra, n. 41, Colloquia 3, Coimbra Editora, Boletim da Faculdade de Direito, Stvdia ivridica, 1999 , p. 42-43. 
Com a ajuda disso foi criado seu próprio sistema legal que mais ou menos o liberou das legislações nacionais e do direito internacional privado; o crescimento da judicatura por meio de arbitragem exerce sua influência e resolve as questões utilizando outros padrões que não aqueles utilizados nas Cortes públicas, quanto menos atenção se prestam a todas as provisões legais nacionais." ${ }^{117}$

Atento à dificuldade apontada José Menéres PIMENTEL e diante do risco de atrofiar-se ainda mais a compreensão jurídica do importante contrato, o Senador Humberto COSTA, ao propor o PLS 477/2013, aperfeiçoa os projetos que tomou por base - PL 3.555/2004, do hoje Ministro da Justiça José Eduardo Martins CARDOZO e PL 8.034/2010, do deputado Rubens Moreira MENDES - de forma a não apenas vedar a simples adesão à arbitragem, como também para dispor que qualquer arbitragem será feita no Brasil, submetida ao procedimento e às regras do direito brasileiro", sendo

obrigatória a divulgação dos resumos dos conflitos (...) e das decisões respectivas em repositório administrado pelo órgão fiscalizador ou por entidade de reconhecida utilidade pública dedicada à proteção dos interesses dos segurados e beneficiários de seguro ou consumidores em geral. $^{318}$

A proposta legislativa, na contramão do desenfreado liberalismo financeiro apologista da mais livre pactuação das arbitragens, vem ao encontro das preocupações de Petro PERLINGIERI a respeito da subtração à lei e à jurisdição estatais de um "significativo e relevante número de relações econômicas, que por vezes envolvem aspectos relativos à ordem pública constitucional indisponíveis e decisivos para a qualidade de vida do país", questão que impõe ao jurista adotar como tarefa "contribuir para realizar, mediante uma renovada teoria da interpretação, axiologicamente orientada, uma justiça civil na legalidade constitucional e comunitária, utilizando os conteúdos e os valores característicos de tal legalidade não apenas na "releitura" de velhas e novas normas em nível ordinário, mas também na aplicação direta dos enunciados constitucionais":

317 Justificativa ao PLS 477/2013, autor o Senador Humberto COSTA. Disponível em http://www.senado.gov.br/atividade/materia/detalhes.asp?p_cod_mate=115225. Acesso em 12 de dezembro de 2013.

318 “Art. 66. A resolução de litígios por meios alternativos não será pactuada por adesão a cláusulas e condições predispostas, exigindo instrumento assinado pelas partes, e será feita no Brasil, submetida ao procedimento e às regras do direito brasileiro.

Parágrafo único. É obrigatória a divulgação dos resumos dos conflitos, sem identificações particulares, e das decisões respectivas em repositório administrado pelo órgão fiscalizador ou por entidade de reconhecida utilidade pública dedicada à proteção dos interesses dos segurados e beneficiários de seguro ou consumidores em geral."

Disponível em http://www.senado.gov.br/atividade/materia/detalhes.asp?p_cod_mate=115225. Acesso em 12 de dezembro de 2013. 
É preocupante constatar que, atualmente, as relações civis que são levadas à justiça estatal são as relativas à microeconomia, enquanto aquelas atinentes à macroeconomia vivem a difícil conjuntura, no mais das vezes, na justiça privada de natureza arbitral. Quanto isso seja fisiológico no desenvolvimento industrial ou devido ao ruim e lento funcionamento da justiça, ou mesmo à própria emergência econômicopolítica, não é fácil dizer. Em um estado que não repudia políticas de intervenção com o objetivo de promover o desenvolvimento dos indivíduos e da coletividade, bem como não renuncia ao controle das atividades econômicas, também mediante as técnicas jurisdicionais, é pelo menos singular que se aceite passivamente a subtração da jurisdição estatal de um tão significativo e relevante número de relações econômicas, que por vezes envolvem aspectos relativos à ordem pública constitucional indisponíveis e decisivos para a qualidade de vida do país. A saída da emergência poderia ser favorecida por um reforço da técnica de controle sobre os atos e as atividades, sobretudo sob o perfil do seu merecimento.

O Direito Civil parece destinado cada vez mais a se caracterizar por instâncias neocorporativas e contratuais, onde a lógica do acordo tende a fazer desenvolver o ordenamento somente em função de posições já adquiridas e consolidadas. A própria desregulamentação, enfaticamente reconfirmada, apresenta-se - mais que como recondução à racionalidade da relação lei-ato administrativo - como incondicionado retorno à liberdade dialética e mercantil. A proposta conexão entre "forma" do direito e "forma" da economia e da sociedade conduziria nesse contexto histórico-político, a um direito tal qual "mera reprodução das articulações mercantis da sociedade", isto é, à autodestruição do direito como expressão de valores autônomos. $\mathrm{O}$ contrato tende a prevalecer sobre a autoridade das leis, com a dispersão dos conteúdos ínsitos na legalidade constitucional, única verdadeira justificação de uma justiça também nas relações civis. A contínua negociação das modalidades e dos conteúdos das relações econômicas e civis reforça ainda mais a ideia de autotutela e não a da confiança nas instituições incumbidas, por definição, da tutela dos interesses e das suas valorações; determina a privatização além da medida dos interesses gerais, a segregação dos deveres de solidariedade, a perda do gosto de concorrer com a participação democrática no funcionamento dos poderes ainda que renovados e ampliados, do Estado do Direito. O resultado que daí deriva é uma crise de identidade da função do juízo jurídico. ${ }^{319}$

A arbitralidade, como ensinam Fernando Antonio Maia da CUNHA e Walfrido Jorge WARDE JR, em certas circunstâncias deve ser restringida, como é o caso daquelas atinentes a companhias abertas em que os interesses de terceiros ficam distantes do palco arbitral. Segundo o autor, a solução tentada pela BM\&FBOVESPA que administra a Bolsa de Valores de São Paulo, consistente na imposição de publicação de ementários destinados a suprir a confidencilidade sob a qual são desenvolvidas as demandas, não é capaz de contornar os inconvenientes do cerceamento ao amplo acesso às informações sobre as

\footnotetext{
${ }^{319}$ PERLINGIERI, Pietro. O direito civil na legalidade constitucional. Tradução de Maria Cristina De Cicco. Rio de Jnaeiro: Renovar, 2008, p. 33-34.
} 
companhias abertas, o que "pode levar a dúvidas e a eventuais crises de fiabilidade do mercado de capitais":

É fato que a recente reforma, a que se submeteu o Regulamento da Câmara do Mercado, para além de mitigar as mazelas regulatórias que tinham, até então, dado fundamento ao fracasso daquela câmara, determinou, em sua cláusula 7 (item 7.10), a veiculação periódica de um ementário de precedentes, sem que fossem reveladas, em concreto, a identidade das partes ou fatos do processo que levem à sua identificação. A medida pretendeu compatibilizar o sigilo que caracteriza o procedimento arbitral à necessidade de apreender o entendimento dominante dos árbitros sobre relevantes questões em matéria de direito societário e de mercado de capitais. Não nos parece, contudo, que seja capaz de fazê-lo. A casuística não prescinde da caracterização minuciosa das questões concretas em apreço, nem mesmo do livre acesso ao analista de todos os fatos do processo. Sem isso, não é possível comparar casos em busca de identidades e de diferenças, aplicar decisões antigas, afastar sua aplicação ou mesmo modificá-las à evolução do entendimento do interprete-judicante.

De resto, (...), a ausência de amplo acesso a informações acerca das companhias abertas pode levar a dúvidas e a eventuais crises de fiabilidade do mercado de capitais. Esse é, por sinal, o entendimento da Securities and Exchange Commission (SEC). ${ }^{320}$

De fato, como demonstram MAIA e WARDE, a escolha de utilização do ambiente protegido das arbitragens como jurisdição dos negócios, importante prenda conquistada e expressão genuína da hipertrofia da autonomia da vontade, ao se tornar padrão nos estatutos das companhias sensibilizou a Suprema Corte norte-americana ${ }^{321}$ e mobilizou a contrariedade da Securities and Exchange Commission (SEC), embora se divise certo afrouxamento nos dias atuais:

Em agosto de 1990, um artigo de Thomas Riesenberg, o então Assistant General Counsel da SEC, descortina e explica o que seria uma oposição generalizada, entre os membros da SEC, às convenções arbitrais estatutárias, com base em fundamentos legais e de política do direito. (Cf. RIESENBERG, Thomas L. "Arbitration and Corporate Governance: A Reply to Carl Schneider, in: Insights, agosto, 1990, disponível em <www.aw.com>. ) Para a Riesenberg, as convenções arbitrais estatutárias não são vantajosas ao requerente e, portanto, contrárias à ideal proteção

\footnotetext{
${ }^{320}$ MAIA DA CUNHA, Fernando Antonio e WARDE JR., Walfrido Jorge. A arbitragem e os limites à atuação do judiciário nos litígios societários. In: YARSHELL, Flávio Luiz; PEREIRA, Guilherme Setoguti J. Processo Societário. São Paulo: Quartier Latin, 2012, p. 725-758, p. 756-757.

${ }^{321}$ MAIA DA CUNHA e WARDE JR., op. cit.: “Ação ajuizada por um cliente em face de sócios de uma corretora de valores mobiliários, para pleitear ressarcimento sob fundamento da Section 12(a)(2) do Securities Act, em razão de perdas experimentadas em negócios com ações realizadas pela corretora, em nome e por conta do cliente, em abuso de representação, bem como em vista do ocultamento de importantes informações acerca da companhia emissora. A Suprema Corte decidiu que o direito de escolher a jurisdição não poderia ser disponível e que uma convenção arbitral celebrada entre a corretora de valores mobiliários e o seu cliente caracterizava-se como uma estipulação obrigando o comprador de valores mobiliários a não observar as determinações do Securities Act. Cf. 346 U.S. 427, 428-29, 74 S. Ct. 182, 183-184, 98 L. Ed. 168, 172 (1953). Foi superado por Rodriguez de Quijas v. Shearson/American Express Inc., cf. 490 U.S. 477, 109 S. Ct 1917, 104 L. Ed. 2d 526 (1989).”
} 
dos investidores porque: (i) impõem à produção antecipada de provas importantes restrições; (ii) dificultam o acesso a medidas de urgência; (iii) inviabilizam ou dificultam as class actions; (iv) o local da arbitragem poderá ser inconveniente ao investidor individual; (v) não permitem um escrutínio público de condutas e a ideal fiscalização de infrações graves por meio de ações judiciais movidas por investidores individuais; e (vi) não é aceitável que imponham uma vedação irrestrita ao acesso a justiça estatal por meio de "pactos coletivos" ao invés de renúncias pessoalíssimas.

Mesmo que a opinião de Riesenberg não se tenha caracterizado como uma opinião oficial da SEC, a verdade é que a entidade jamais se manifestou contrariamente as proposições de seu Assistant General Counsel. Ao contrário, logo em seguida, em outro artigo publicado em setembro do mesmo ano, Richard Breeden, Chairman da SEC, afirmou enfaticamente que as convenções arbitrais estatutárias eram contrárias ao interesse público e à tutela dos investidores. Por outro lado, desde então, a SEC jamais se manifestaria novamente a respeito, seja oficialmente, seja por meio de opiniões de seus membros. E, é bem verdade, nunca se opôs a que companhias brasileiras com American Depositary Receipts ("ADRs") ${ }^{322}$ listados em bolsas de valores norteamericanas empregassem convenções arbitrais em seus estatutos. Esso poderá ser o indício de um afrouxamento do entendimento, mas o mais provável é que tais provisões estatutárias tenham mesmo passado despercebidas pela SEC. ${ }^{323}$

A ausência de decisões judiciais sobre a matéria de seguro e resseguro leva à carência de formulação jurídica sobre esses contratos, perdendo-se a experiÊncia social, como vem acontecendo nos Estados Unidos, segundo informa Özlem GÜRSES:

Antes de começar a abordar o direito do resseguro nos Estados Unidos é necessário notar que a maioria dos litígios envolvendo resseguro são resolvidos por arbitragem e normalmente não há decisão escrita disponível ao publico que apresente os fundamentos da decisão do tribunal arbitral.

(...)

Assim, existe muito pouco sobre o direito do resseguro que seja objeto de decisões judiciais, de forma que os capítulos seguintes irão predominantemente considerar a casuística, mas nem todos os princípios podem ser considerados definitivos. ${ }^{324}$

\footnotetext{
${ }^{322}$ MAIA DA CUNHA e WARDE JR., op. cit.: "São títulos que mencionam o direito de propriedade de ações de emissão de uma companhia, entregues a um dado depositário, invariavelmente uma instituição financeira no país onde se deu a sua emissão, que deverá custodiá-las, por força de um contrato de depósito celebrado entre a companhia emissora, a instituição financeira e o proprietário das ações. As ADRs podem ser trocadas, a qualquer tempo, pelas ações que menciona. Sob um aspecto puramente econômico, os titulares de $A D R s$ são acionistas, daí porque são assim tratados pelas cortes norteamericanas."

${ }^{323}$ Idem, p. 757-758.

324 GÜRSES, Özlem. Reinsuring Clauses. Londres: Lloyd's List, 2010, p. 05: "Before starting to add information with regards to reinsurance law in the United States it is necessary to note that most reinsurance disputes in the US are resolved by arbitration and there is typically no publicly available written decision explaining the reasons for the decision of the arbitrator panel. (...) Thus, there is little concerning reinsurance law that is firmly settled in the US by court decision, so the following chapters will for the most part consider case law, but not all of the principles stated can be considered settled law."
} 
Giesela RÜHL reconhece que, tanto no Direito Europeu quanto no Anglo-Saxão, e especialmente em tema de seguro, o afastamento da lei aplicável é visto com reservas, tendendo-se a restingir a escolha das partes. Também aponta nesses ordenamentos jurídicos o abrandamento da autonomia da vontade, que seria justificável pela própria teoria econômica, em razão das falhas de mercado, e dessa vez não só no direito do seguro, como também no direito do consumidor e do trabalho ${ }^{325}$.

A mais recente lei nacional de contrato de seguro é a Lei peruana n. 29.946, de 27 de novembro de 2012, que entrou em vigor no ano seguinte. Nela, como acontece com o a lei argentina, que veda a previsão de arbitragem nos seguros (Lei n. 14.418, de 30 de agosto de 1967, art. 57), e também com o nosso PLS 477/2013, que limita a liberdade de sua contratação, há dispositivo (art. 40) que considera nulas de pleno direito cláusulas que impliquem renúncia, pelos segurados e beneficiários, a privilégios jurisdicionais ou leis que os favoreçam e cláusulas que proibam ou restinjam o direito do segurado à tutela judical estatal, apenas permitindo serem pactuadas arbitragens ou outros modos de solução de controvérisa para discutir a respeito de sinsitros já acontecidos:

Art. 40. Sem prejuízo do estabelecido no artigo anterior, com caráter enunciativo, as empresas estão proibidas de incluir nas apólices de seguro as senguintes estipulações, que serão nulas de pleno direito:

a) cláusulas mediante as quais os segurados e/ou beneficiários renunciem à jurisdição e/ou leis que lhes favoreçcam.

(...)

b) cláusulas que proíbam ou restrinjam o direito dos egurado a submeter a controvérsia à via judicial, sem prejuízo de seu direito de pactuar com os egurador, uma vez ocorrido o sinistro, a submissão do caso a arbitragem ou outro meio de solução de controvérsias. ${ }^{326}$

Como enfatiza o senador Humberto COSTA, com apoio em BERCOVICI e OCTAVIANI, intervir na direção do conteúdo dos contratos de seguro é operacionalizar a socialidade com matiz desenvolvimentista:

\footnotetext{
${ }^{325}$ I have argued that American law and European law do not only allow parties to choose the applicable law but also restrict the freedom of choice in the same situations and in similar ways. Second, I have illustrated that the trend of convergence in the context of party autonomy can be explained with the help of economic theory. I have reasoned that the principle of party autonomy is an efficient approach in the private international law of contracts and that limitations to party autonomy, especially those in consumer, insurance, and employment contracts can be explained with the presence of market failure, most importantly, opportunistic behavior, and information asymmetry. On the other hand, I have demonstrated that other limitations to party autonomy, such as the limitation of the parties' choice to state laws and to related laws, have no apparent economic underpinning, and that their recent - or soon to be expected - abandomment finds support in economic theory. (RÜHL, Giesela. Conflict of Laws in a Globalized World. Cambridge, 2007, p. 183).

326 “Art. 40. Sin perjuicio de lo establecido en el artículo anterior, con carácter enunciativo, las empresas están prohibidas de incluir en las pólizas de seguro las siguientes estipulaciones, que serán nulas de pleno derecho: a) cláusulas mediante las cuales los asegurados y/o beneficiarios renuncien a la jurisdicion y/o leyes que los favorezcan. (...) c) cláusulas que prohíban o restrinjan el derecho del asegurado a someter la controversia a la vía judicial, sin perjuicio de su derecho de acordar con el asegurador, recién una vez producido el siniestro, el sometimiento del caso a arbitraje u otro medio de solución de controversias."
} 
Não se trata de intervenção para regular quaisquer contratos, mas contratos relevantes para o conjunto social e para o desenvolvimento do país, que se caracterizam por serem de típica adesão, cujos conteúdos são predispostos pelos seguradores ou, nos grandes riscos, pelos resseguradores, motivo pelo qual Gilberto Bercovici salienta que " $O$ controle e a fiscalização do Estado são, neste caso, essenciais, (...) para tornar efetiva a garantia ao segurado, ou seja pelo "simples" fato de que os recursos manejados pelo setor securitário e ressecuritário são provenientes da poupança pública. ${ }^{327}$

Os seguros são contratos voltados para o cumprimento, no seu conjunto e com sua expansão, da diretriz da solidarização e demais cometimentos constitucionais, como o desenvolvimento das empresas brasileiras, o fortalecimento do mercado interno, enfim, o desenvolvimento social e econômico e a democratização da economia, como bem recorda OCTAVIANI:

"No Brasil, pode-se afirmar que a atuação do Estado em âmbito econômico - na e sobre a economia - constitucionalmente vinculada, traz um desenho que dirige o contrato, a empresa e o mercado de seguro, com vistas a expandir para o máximo de cidadãos as possibilidades de garantir seus interesses legítimos contra os riscos presentes na sociedade contemporânea." ${ }^{328}$

\subsubsection{Regulação de sinistro}

Embora o acesso a determinadas atividades econômicas pressuponha a contratação de seguros, é unânime o reconhecimento de que o momento em que os segurados e beneficiários mais precisam do seguro é aquele em que se vêem às voltas com um sinistro. Isso porque, além da gravidade da conjuntura, que desorganiza o status quo a exigir energias e atividades inesperadas, emerge urgente necessidade financeira.

Já mencionamos a articulação com a própria função do seguro dessa urgência com que é demandado o salvamento e a indenização a que se obrigou a seguradora. Nas palavras de MORANDI, "um sistema segurador idôneo, além de perseguir o baixo custo dos prêmios, deve fazer com que as indenizações cheguem ao segurado em tempo

327 BERCOVICI, Gilberto. Estado, resseguro e a industrialização brasileir. In: Liber amicorum Homenagem ao Prof. Doutor António José Avelãs Nunes. Coimbra: Coimbra Editora, 2009, p. 355.

${ }^{328}$ Voto do relator Alessandro S. Octaviani Luis, aprovado por unanimidade no Ato de Concentração $\mathrm{n}^{\circ}$ 08012.005526/2010-39, 14.03.2012, CADE - Conselho Administrativo de Defesa Econômica. 
oportuno, para que o seguro cumpra com sua função social, que o vitaliza e constitui sua razão de ser., 329

Nos anos 1990, o desmantelamento do IRB expunha as regulações e liquidações dos sinistros brasileiros a um sem número de dificuldades. As praxes se desorganizavam e os resseguradores estrangeiros passaram a impor que os procedimentos de regulação de sinistro fossem controlados por eles, para o que envolviam peritos e empresa de regulação e liquidação de sinistro internacionais de sua confiança.

As regulações outrora feitas pelo IRB primavam pela democrática discussão das apurações e conclusões, sobre cobertura e prejuízos indenizáveis. Agora, o próprio IRB, enfraquecido e acossado, apesar da lei outorgar-lhe a competência para dirigir as regulações de sinistro, tornava confidenciais esses procedimentos. Desse modo, o país perdia não apenas o conteúdo de seus seguros, como também a direção da fase mais importante da relação obrigacional, aquela em que o seguro reintroduz na economia os recursos para repor as forças produtivas e manter a organização econômica e social.

O problema motivou a análise do procedimento de regulação e liquidação de sinistro pela doutrina jurídica brasileira e em 1999 foi editada a primeira monografia brasileira sobre o assunto, onde se afirmou que se trata de serviço devido pela seguradora aos segurados e beneficiários, destinado a apurar a existência e a grandeza da dívida indenizatória da seguradora, portanto um procedimento de seu comum interesse, que deve zelar para que a dívida apurada seja solvida com a máxima exatidão e rapidez, sob pena de sua desfuncionalização. ${ }^{330}$

Na doutrina internacional, a relevância do bom funcionamento das regulações de sinistro é bastante enfatizada, assim como a tendência ao abuso por parte dos seguradores em razão da insuficiência de normas sobre essa especial atividade, merecendo destaque a doutrina de Alberto MONTI:

Nesta fase, no entanto, são inúmeros os incentivos para que o segurador se comporte de forma oportunista, contestando até mesmo aqueles pedidos de indenização que não apresentam elementos objetivos de incerteza em relação à operatividade da cobertura.

Em primeiro lugar, o segurador está bem ciente do estado de necessidade em que se encontra o segurado, cuja condição econômica e psicológica foi adversamente influenciada pela ocorrência do evento danoso. $\mathrm{O}$ fator tempo é crucial para o segurado, o qual, após sofrer o dano, muitas vezes, tem uma necessidade quase que imediata de valer-se da indenização

\footnotetext{
${ }^{329}$ MORANDI, Juan Carlos F. El riesgo en el contrato de seguro: régimen de las modificaciones que lo agravan, cit., p. 27 , nota 6.

${ }^{330}$ TZIRULNIK, Ernesto e OCTAVIANI, Alessandro. Regulação de sinistro (ensaio jurídico), 3. ed. São Paulo: Max Limonad, 2001. Ver também THEODORO JÚNIOR, Humberto.
} 
garantida. Por outro lado, o decorrer do tempo joga a favor do segurador que, na maioria dos casos, é devedor pecuniário e tira vantagem da intempestividade do pagamento. De fato, sabe-se que todos os sistemas jurídicos atualmente se encontram em apuros para constringir os devedores monetários a pagar efetivamente, e nos termos previstos; até porque os mecanismos da Justiça Civil se encontram em um estado de crise mais ou menos pronunciado.

Fazendo apelo a esses recursos, a companhia poderá, assim, ser induzida a adotar estratégias aparentemente vexatórias - como a peremptória (e arbitrária) recusa em pagar a indenização acordada, justificada por unilaterais e pretensiosas determinações de inaplicabilidade da garantia, ou então, o acionamento de inúteis e extenuantes procedimentos dilatórios na fase de regulação e liquidação - com o objetivo de convencer o segurado a firmar uma transação por um valor significativamente inferior à indenização devida por contrato. Como dito anteriormente, para o segurador a ameaça de um processo judicial será meramente um pano de fundo, sem interferir de forma determinante nas decisões, pois o recurso ao sistema judicial requer um custo considerável do segurado e o tempo da Justiça nem sempre responde às exigências de quem se encontra em uma situação financeira precária. (...) Além do mais: deve-se também descontar o efeito daquele peculiar fenômeno que surge sob o nome de underlitigation, ou seja, do fato, bem conhecido por grandes empresas, de que apenas um número limitado de casos chegam às salas dos Tribunais.

As lacunas na disciplina contratual do processo de regulação e liquidação, portanto, dão margem ao acionamento desses comportamentos oportunistas, que, na ausência de uma medida corretiva, permitem que o segurador dê prosseguimento unilateral a uma redistribuição arbitrária dos benefícios decorrentes do contrato, privando a contraparte de uma parcela substancial dos benefícios esperados. ${ }^{331}$

${ }^{331}$ MONTI, Alberto. Buona Fede e Assicurazione. Milano: Dott. A. Giuffrè Editore, p. 30, 31, 32, 33. Original em italiano: "In questa fase, tuttavia, numerosi sono gli incentivi per l'assicuratore a comportarsi opportunisticamente, contestando anche quelle richieste di indennizzo le quali non presentano obiettivi elementi di incertezza in relazione all'operatività della copertura. In primo luogo, l'assicuratore è ben a conoscenza dello stato di bisogno in cui versa l'assicurato, la cui condizione economica e psicologica è stata avversamente influenzata dal verificarsi dell'evento di danno. Il fattore tempo è cruciale per l'assicurato, il quale, una volta subito il danno, ha sovente una necessità pressoché immediata di avvalersi dell'indennizzo garantito. Per converso, il trascorrere del tempo gioca a vantaggio dell'assicuratore il quale, nella maggioranza dei casi, è debitore pecuniario e trae beneficio dall'intempestività del pagamento. Infatti, è nota la circostanza per cui tutti i sistemi giuridici si trovano attualmente in affanno nel constrigere i debitori monetari a pagare effettivamente e nei termini previsti, anche perché i meccanismi della giustizia civile versano in uno stato di crisi più o meno accentuata. Facendo leva su questi tasti, la compagnia potrà quindi essere indotta ad attuare strategie all'apparenza vessatorie - quali il perentorio (e arbitrario) rifiuto di versare l'indennizzo pattuito, giustificato da unilaterali e pretenziose determinazioni di inoperatività della garanzia, oppure la messa in opera di inutili quanto snervanti procedure dilatorie nella fase di accertamento e liquidazione - con lo scopo di convincere l'assicurato a stipulare una transazione per un ammontare significativamente inferiore all'indennità dovuta per contratto. Come detto, per l'assicuratore la minaccia di una lite in giuzidio resterà meramente sullo sfondo, senza interferire in modo determinante nelle decisioni, poiché il ricorso al sistema delle corti comporta un notevole costo per l'assicurato e i tempi della giustizia non sempre rispondono alle esigenze di chi si trova in una situazione economica precaria.(...) Ma non solo: bisogna anche scontare l'effetto di quel peculiare fenomeno che va sotto il nome di underlitigation, ossia del fatto, ben noto alle grandi imprese, che solo un numero limitato di casi raggiunge le aule dei Tribunali. Le lacune nella disciplina contrattuale della procedura di accertamento e liquidazione creano dunque spazio per la messa in opera di siffatti comportamenti opportunistici i quali, in assenza di un intervento correttivo, consentono all'assicuratore di procedere unilateralmente ad una arbitraria riallocazione dei benefici derivanti dal contratto, privando la controparte di una notevole porzione dei benefici attesi. In questo modo, inoltre, 
No mesmo sentido, o guia para seguros de interesses atinentes a economias em desenvolvimento ou transição editado pela UNCTAD salienta que a rapidez das regulações e liquidações de sinistro exigem celeridde, não se justificando o contrário nem mesmo diante da possibilidade de prática de fraudes por parte dos reclamantes da prestação indenizatória:

Speed is important in the processing of claims. Once a loss is elegible to become the subject of a claim, examiners or assessors must be able to trace each claim from the overdue account advice stage. They must also make sure all details concerning each claim are available for quick reference to those who make the final decision.

Claims assessors must also be alive to the possibility that the claimant has not fulfilled all its obligations under the policy (e.g. submitted accurate declarations, put the appropriate credit limits in place, paid the premiums on time.). They must also be aware that some policyholders may 'edit' their claims to cover any shortcomings in their obligations.

The claims personnel therefore need to be meticulous in their examination of the claims whilst avoiding delays or giving the policyholder the idea that the company is trying to avoid its responsabilities. Insurance companies unfortunately have a worldwide reputation for using the smal print to escape paying claims. The fact that many of them are often the victims of fraudulent misrepresentations does not deter the public from believing the worst of their motives when they are over-cautions. ${ }^{332}$

Esse importante momento da execução do contrato de seguro tem sido regulado no Brasil de maneira insuficiente e que entrega às companhias seguradoras ampla discricionariedade.

Embora a Circular SUSEP n. 256, de 16 de junho de 2004, contenha uma seção intitulada "SEÇÃO XIII - DA LIQUIDAÇÃO DE SINISTROS”, a regulação ali existente limita-se a uma regra na qual os prazos para as regulações de sinistro são de até 30 dias, contados da apresentação de todos os documentos básicos previstos pela seguradora para cada tipo de cobertura (art. 33, $\S 1^{\circ}$ ). Caso tenha dúvida fundada, a regra prevê que a seguradora pode solicitar apresentação de documentação ou informação complementar - e isto pode acontecer sucessivas vezes -, então o prazo de até 30 dias fixado pela seguradora será suspenso

l'impresa è in grado di esternalizzare dei costi sulla massa degli assicurati e di offrire, per conseguenza, premi ingannevolmente più bassi. L'effetto negativo derivante all'immagine della compagnia sul fronte della reputazione viene così smorzato agli occhi dei nuovi potenziali assicurati i quali, forse in ragione delle menzionate problematiche di natura psicologica e cognitiva, fissano l'attenzione sull'attraente livello dei premi piuttosto che farsi scoraggiare dalla nefasta esperienza altrui."

${ }^{332}$ INTERNATIONAL TRADE CENTRE UNCTAD/WTO. Export credit insurance and guarante schemes - A practical guide for developing and transition economies. Geneva: ITC, 1998. Viii, p. 74-75. 
e terá contagem reiniciada "a partir do dia útil subsequente àquele em que forem completamente atendidas as exigências" $\left(\S 2^{\circ}\right) .{ }^{333}$

Como se vê, a regulamentação não bloqueia a procrastinação, nem traz mecanismos capazes de atribuir operatividade à obrigação de regular e liquidar os sinistros. Também há completa omissão a respeito do direito de participação dos segurados e beneficiários no procedimento, bem como do direito de acesso aos documentos e elementos colhidos ao longo da regulação.

\footnotetext{
${ }^{333}$ Art. 33. Deverão ser informados os procedimentos para liquidação de sinistros, com especificação dos documentos básicos previstos a serem apresentados para cada tipo de cobertura, facultando-se às sociedades seguradoras, no caso de dúvida fundada e justificável, a solicitação de outros documentos. § 1o Deverá ser estabelecido prazo para a liquidação dos sinistros, limitado a 30 (trinta) dias, contados a partir da entrega de todos os documentos básicos previstos no caput deste artigo, ressalvado o disposto no parágrafo $2 \underline{\mathrm{o}}$ deste artigo.

$\S 2^{\circ}$ Deverá ser estabelecido que no caso de solicitação de documentação e/ou informação complementar, na forma prevista no caput deste artigo, o prazo de que trata o parágrafo anterior será suspenso, reiniciando sua contagem a partir do dia útil subsequente àquele em que forem completamente atendidas as exigências.
} 


\section{Capítulo 5: Projetos de Lei de Contrato de Seguro}

Diante do paulatino enfraquecimento da estrutura intervencionista, que culminaria com o alijamento do IRB pelo Estado brasileiro, nos anos 1990 os contratos de seguro, como acabamos de demonstrar, já vinham sofrendo fragilização de conteúdo. Também era notória a instalação no país de práticas discriminatórias de segurados e de setores produtivos. Com o enfraquecimento da atividade estatal, revelava-se, ainda, a tendência à descontinuidade das garantias de seguro e a entrega das regulações e liquidações de sinistros a reguladores e peritos escolhidos pelos resseguradores estrangeiros. Tudo isso se sentia nitidamente, afetando os seguros de massa e os de grande vulto, como são os de riscos operacionais e os seguros de riscos de engenharia ou construção.

O receio de desestruturação do sistema, não quanto às margens de solvência financeira das seguradoras, mas na sua funcionalidade social, agravou-se quando sobreveio o Código Civil de 2002, com regramento parco e predominantemente arcaico no que diz respeito ao contrato de seguro.

Com o intuito de reagir às ameaças divisadas e contribuir para a reaproximação do negócio securitário com a realidade social e as diretrizes constitucionais, notadamente a funcionalidade social e o desenvolvimento do país, o Instituto Brasileiro de Direito do Seguro (IBDS), criado em 2000, coordenou a elaboração de um anteprojeto de lei de contrato de seguro que buscou compor-se de dispositivos capazes de atender tais propósitos, solucionando as principais questões, como a necessidade de democratização do acesso ao serviço securitário e de promoção da eficácia social e econômica dos conteúdos dos seguros.

Com base nesse trabalho, em 13 de maio de 2004, o então deputado José Eduardo Martins CARDOZO, um dos fundadores do IBDS, apresentou ao Congresso Nacional o Projeto de Lei n. 3.555/2004 que, uma vez aprovado, resultaria na nossa primeira Lei de Contrato de Seguro.

Após intensa discussão na sociedade, o texto recebeu inúmeros aperfeiçoamentos, consolidados em dois substitutivos. Contudo, a iniciativa corria o risco de ser arquivada porque seu autor deixaria de ser parlamentar, tendo sido salva pela apresentação do Projeto de Lei n. 8.034/2010, do deputado Rubens Moreira MENDES. 
Na Comissão Especial constituída na Câmara dos Deputados para apreciar o PL n. 3.555/2004 - e o anexo PL n. 8.034/2010 -, sobreveio relatório do deputado Armando Vergílio dos SANTOS JÚNIOR, cujo conteúdo notoriamente retrógrado ${ }^{334}$ motivou a apresentação do PLS n. 477/2013 pelo Senador Humberto COSTA, que apresenta regramento bastante similar aos dos dois projetos mencionados. Segundo o este parlamentar, era necessário o projeto de

[u]ma LCS que, além disso, realmente beneficie a indústria nacional, e especialmente o setor de infraestrutura, garantindo relações de seguro e resseguro que cumpram o papel de viabilizar de maneira estruturada financiamentos e obras de grande vulto, essenciais ao desenvolvimento do país, ameaçadas, como se vê na imprensa que tanto vem divulgando nos últimos dias o destino do seguro de Jirau disputado por interesses estrangeiros que tentam, senão aplicar suas leis aos nossos negócios ou atribuir os julgamentos a juízes com as tradições e cultura que comungam, ao menos demandar em Londres os relevantes interesses de obra de infraestrutura do PAC financiada com dinheiro público, onerando sem racionalidade alguma as contrapartes brasileiras. ${ }^{335}$

O objetivo central dos dispositivos do PLS n. 4777/2004 é a funcionalização dos seguros para que contribuam com o atingimento das diretrizes e objetivos constitucionais, e para isso também resgatam as potencialidades da teoria do interesse, que recebe um capítulo próprio (Capítulo II - Interesse). ${ }^{336}$

Após dispor que "[a] atividade seguradora será exercida de modo que se viabilizem os objetivos da República, os fins da ordem econômica e a plena capacidade do mercado interno" (art. $1^{\circ}$ ), esclarece que integram essa atividade "além dos contratos de seguro, também os contratos necessários à sua plena viabilidade, como o resseguro e a retrocessão" (art. $\left.2^{\circ}\right)$.

${ }^{334}$ Ver MANIFESTAÇÃO PÚBLICA do IBDS - Instituto Brasileiro de Direito do Seguro sobre o PROJETO DE LEI DE CONTRATO DE SEGURO: Deputado Armando Vergílio, relator do Projeto na Comissão Especial do PL 3.555/2004 apresenta Substitutivo desastroso para os consumidores, empresários, sociedade civil em geral, seguradoras, resseguradores e corretores: uma lei de seguro atécnica e reacionária. Disponível em http://www.ibds.com.br/artigos/ibds-manifestacao-publica-pl3555-substitutivo-deputadoarmando-vergilio.pdf. Acesso em 21 de dezembro de 2013.

335 Projeto de Lei n. 477, de 12 de novembro de 2013. Disponível em: <http://www.senado.gov.br/atividade/materia/detalhes.asp?p_cod_mate=115225>. Acesso em $12 \mathrm{de}$ novembro.

${ }^{336}$ São diversos os artigos do PLS n. 477/2013 destinados a proteger a penetração da teoria do interesse nos contratos. Além de encontrar-se na própria definição de seguro (art. $6^{\circ}$ ), a técnica é aplicada, por exemplo, na definição de seguros estipulados em favor de terceiros: "Art. 27. O seguro será estipulado em favor de terceiro quando a contratação recair sobre interesse de titular distinto do estipulante, determinado ou determinável. $\S \mathbf{1}^{\mathbf{0}} \mathrm{O}$ beneficiário será identificado pela lei, por ato de vontade anterior à ocorrência do sinistro ou, a qualquer tempo, pela titularidade do interesse garantido. $\$ \mathbf{2}^{\circ}$ Sendo determinado o beneficiário a título oneroso, a seguradora e o estipulante deverão, tão logo quanto possível, entregar-lhe cópia da totalidade dos instrumentos que conformam o contrato de seguro." 
Com o objetivo de garantir a submissão dos seguros à lei de seguro do país, estabelece a obrigatoriedade de incidência dessa lei em diversas hipóteses, destacando com especial atenção aqueles cujos "interesses garantidos recaiam sobre obras consideradas relevantes para o desenvolvimento da infraestrutura brasileira" (art. $\left.9^{\circ}, \S 1^{\circ}, I V\right)$.

Prevê que os contratos devem ser redigidos em língua portuguesa (art. 54, caput) e que "[s]erão nulas as cláusulas redigidas em idioma estrangeiro ou que se limitem a referir regras de uso internacional." (art. 54, $2^{\circ}$ ).

Ainda visando promover o desenvolvimento da experiência jurídica nacional, e proteger os interesses do conjunto de interessados nos seguros, prevê que "[a] resolução de litígios por meios alternativos não será pactuada por adesão a cláusulas e condições predispostas, exigindo instrumento assinado pelas partes, e será feita no Brasil, submetida ao procedimento e às regras do direito brasileiro" (art. 66, caput) e considera obrigatória "a divulgação dos resumos dos conflitos, sem identificações particulares, e das decisões respectivas em repositório administrado pelo órgão fiscalizador ou por entidade de reconhecida utilidade pública dedicada à proteção dos interesses dos segurados e beneficiários de seguro ou consumidores em geral" (art. 66, parágrafo único).

Procurando que os valores constitucionais sejam apropriados nos contratos de seguro e que restrinjam a prática de políticas discriminatórias, o PLS n. 477/2013 estabelece que "[o]s critérios comerciais e técnicos de subscrição ou aceitação de riscos devem promover a solidarização e o desenvolvimento econômico e social, sendo vedadas políticas técnicas e comerciais conducentes à discriminação social ou prejudiciais à livre iniciativa empresarial” (art. 55, $\S 7^{\circ}$ ). Para garantir a eficácia dessa regra, o Projeto obriga a seguradora a informar as razões da recusa de subscrição quando tempestivamente questionada pelo interessado (art. $55, \S 8^{\circ}$ ), sob pena de considerar-se aceito o seguro (art. $55, \S 10)$.

São inúmeros os dispositivos do PLS n. 477/2013 destinados à operatividade dos contratos de seguro, restituindo-lhes eficácia social ou conteúdo garantidor.

Anteriormente vimos que a regulamentação administrativa do IRB, quando ainda agente da política governamental, e da SUSEP veio tornando insegura e penosa a obtenção de proteções continuadas, aumentando exageradamente a discricionariedade das seguradoras e seus resseguradores em detrimento da tranquilidade dos titulares dos interesses seguráveis. O PLS n. 477/2013, procurando deter os abusos, estabelece regra 
para evitar a surpresa dos segurados com recusas de renovação ou mudanças súbitas dos conteúdos das garantias a serem renovadas (art. 57, caput).

Além disso, para o seguro que exija vigência coincidente com todo o período durante o qual o interesse se expõe às ameaças passíveis de serem cobertas, como o seguro para a execução de obras de infraestrutura e o seguro de riscos de engenharia ou construção, o Projeto é imperativo no sentido de que o contrato "será prorrogado até sua conclusão, ressalvado o direito da seguradora à diferença de prêmio proporcional ao aumento do tempo do contrato em razão da prorrogação".

Foi visto, também, que a ação normativa da Administração Pública produziu o agigantamento das consequências negativas do agravamento do risco em detrimento da segurança dos serviços securitários. A alegação de agravamento é bastante utilizada para as seguradoras negarem o pagamento das indenizações reclamadas. Para solucionar esse problema, o PLS n. 477/2013 mantém o dever de comunicação do agravamento, mas restringe esse dever ao agravamento relevante e define-o: "Será relevante o agravamento que conduza ao aumento substancial e duradouro da probabilidade de realização do risco ou da severidade de seus efeitos.” (art. 18, § $1^{\circ}$ ).

A preservação da utilidade da técnica do salvamento que, como demonstrado, veio sendo deprimida pela ação normativa estatal e nas apólices predispostas pelas seguradoras, é igualmente objeto de cuidado no PLS ao dispor que "[n]os seguros de dano, as despesas com as medidas de salvamento para evitar o sinistro iminente ou atenuar seus efeitos, mesmo que realizadas por terceiros, correm por conta da seguradora, sem reduzir a garantia do seguro" (art. 75).

O problema dos sinistros complexos, como geralmente são aqueles envolvendo obras de engenharia, é solucionado com regra como aquela que prevê que "[a] seguradora responde, nos termos da lei e do contrato, pelos efeitos do sinistro ocorrido ou cuja ocorrência tiver início na vigência do contrato, ainda que se manifestem ou perdurem após o término desta" (art. 76).

O resseguro é funcionalizado através de poucas regras destinadas a proteger a eficácia dos vínculos contratuais securitários estabelecidos entre a seguradora ressegurada e seus clientes. Uma dessas regras é aquela que estabelece que “[o] resseguro abrangerá a totalidade do interesse ressegurado, incluído o interesse da seguradora relacionado à recuperação dos efeitos da mora no cumprimento dos contratos de seguro, bem como as 
despesas de salvamento e as efetuadas em virtude da regulação e liquidação dos sinistros" (art. 71).

Outro ponto que abala a segurança jurídica, decorrente da ação normativa estatal, a qual nitidamente transfere para os segurados desajustes da relação entre resseguradoras e seguradoras.

Os contratos de seguro formam-se com a aceitação da seguradora. A aceitação também ocorre com o simples silêncio, caso ela não recuse expressamente a proposta feita pelo pretendente ao seguro, no prazo de 15 dias ou inferior, como dispõe a Circular SUSEP n. 251 , de 15 de abril de 2004 , no caput do art. $2^{\circ}$ e $\S \S 4^{\circ}$ a $6^{\circ}$.

O regime salutar de formação do seguro diante do silêncio prolongado da seguradora, que vigorou por décadas no país, é anulado pela novidadeira regra do art. $3^{\circ}$ do mesmo ato administrativo, ao dispor que são supensos os prazos dados à seguradora caso o seguro dependa de contratação ou alteração de resseguro facultativo, até que a resseguradora se manifeste formalmente. ${ }^{337}$

A Resolução CNSP n. 241, de 2011, ao tratar da "Da Consulta aos Resseguradores Locais, Admitidos e Eventuais", torna ainda mais desfavorável para os segurados e beneficiários esse problema decorrente da hipertrofiada liberdade para a formação dos contratos de resseguro e revela com nitidez que o Estado atua em favor das seguradoras e resseguradoras, não para a sociedade.

Isso porque seu art. $5^{\circ}$, parágrafos $2^{\circ}$ e $3^{\circ}$, estabelece que os resseguradores disporão de "prazo de 5 (cinco) dias úteis, no caso dos contratos facultativos, e de 10 (dez) dias úteis, no caso dos contratos automáticos, para formalizar a aceitação total ou parcial do risco" $\left(\S 2^{\circ}\right)$ e que "[a] ausência de manifestação dos resseguradores, no prazo a que se refere o parágrafo anterior, será considerada como recusa" $\left(\S 3^{\circ}\right)$.

${ }^{337}$ CIRCULAR SUSEP n ${ }^{\circ} 251$, de 15 de abril de 2004.

"Art. $2^{\circ}$ A sociedade seguradora terá o prazo de 15 (quinze) dias para manifestar-se sobre a proposta, contados a partir da data de seu recebimento, seja para seguros novos ou renovações, bem como para alterações que impliquem modificação do risco."

(...)

$\S 4^{\circ}$ Ficará a critério da sociedade seguradora a decisão de informar ou não, por escrito, ao proponente, ao seu representante legal ou corretor de seguros, sobre a aceitação da proposta, devendo, no entanto, obrigatoriamente, proceder à comunicação formal, no caso de sua não aceitação, justificando a recusa.

$\S 5^{\circ}$ Tratando-se de contrato de seguro do ramo transportes, cuja cobertura se restrinja a uma viagem apenas, o prazo previsto no caput deste artigo será reduzido para 7 (sete) dias.

$\S 6^{\circ}$ A ausência de manifestação, por escrito, da sociedade seguradora, nos prazos previstos neste artigo, caracterizará a aceitação tácita da proposta.

Art. $3^{\circ}$ Nos casos em que a aceitação da proposta dependa de contratação ou alteração da cobertura de resseguro facultativo, os prazos previstos no artigo $2^{\circ}$ desta Circular serão suspensos, até que o ressegurador se manifeste formalmente." 
Cuidando também desse paradoxo, o PLS n. 477/2013 compatibiliza o regime de formação do resseguro com o do seguro, estabelecendo que o primeiro "é funcional para o exercício da atividade da seguradora e será formado segundo o mesmo regime de aceitação tácita aplicável ao contrato de seguro, na metade do prazo (...)”(art. 67 e parágrafo único). 


\section{CONSIDERAÇÕES FINAIS}

A proposta deste trabalho foi examinar os contratos de seguro de riscos de engenharia como instrumento para o desenvolvimento nacional.

No primeiro capítulo, pudemos demonstrar que a socialidade é uma característica inerente aos contratos de seguro cujas prestações são socialmente estabelecidas, ainda que a observação individualizada de cada contrato dificulte a percepção desse fenômeno. Vimos, também ali, que os proveitos socioeconômicos da operação securitária, que se materializa através de cada um dos contratos, são de grande relevância e inúmeros, motivando o controle rígido por parte dos Estados nacionais.

No segundo capítulo, apuramos que é comum ser enfatizada a função social do contrato de seguro em virtude da penetração da operação securitária coletiva em cada um dos vínculos que a compõem. Além disso, pudemos verificar que não obstante as divergências doutrinárias a respeito do significado da expressão "função social" utilizada no art. 421 do Código Civil, seu exame na perspectiva dos contratos de seguro leva à conclusão de que não se trata de limitar a autonomia da vontade, nem tão só de redução do dogma da relatividade contratual, mas de funcionalizá-la socialmente, atribuindo ao contrato um conteúdo que atenda aos legítimos interesses das partes contratantes e sejam o mais proveitosos para a sociedade como um todo.

O terceiro capítulo permitiu verificar que o seguro é instrumento de política econômica para o desenvolvimento econômico e social, devendo ser compreendido sob a perspectiva dos escopos sociais e econômicos necessários para o cumprimento dos objetivos constitucionalmente atribuídos à República. Apurou-se, ainda, que o Estado brasileiro integrou o seguro ao seu projeto de desenvolvimento social e econômico, regulando e fiscalizando as operações e os contratos não apenas para limitar a autonomia dos particulares, mas para funcionalizar os seguros em prol dos segurados e dos beneficiários, assim como da solidarização social.

O quarto capítulo cuida dos seguros de risco de engenharia. Contextualiza-os historicamente e apura que seu conteúdo vem perdendo a funcionalização dele esperada para promover o bem-estar social e o desenvolvimento do país.

Constata-se que o esvaziamento da eficácia individual e social desses seguros atinentes às construções, montagens e instalações é promovido não apenas pelo mercado 
segurador e ressegurador, mas pela ação normativa dos próprios órgãos públicos que controlam e fiscalizam as operações e os contratos de seguro. São identificados os principais problemas, notadamente a desconstrução da teoria do interesse, as dificuldades colocadas para que as vigências dos contratos de seguro acompanhem todo o período das obras, as falhas do sistema de arbitragem e os descontroles das regulações e liquidações dos sinistros. Finalmente, são apresentadas as respostas do Projeto de Lei do Senado n. 477/2013 para conter a depressão da eficácia individual e social dos seguros de riscos de engenharia e análogos, de forma que possam continuar servindo à construção de uma sociedade mais digna, justa e solidária. 


\section{REFERÊNCIAS}

ALBERT, Michel. Capitalismo versus Capitalismo. São Paulo: Loyola, 1992.

ALBERTI, Verena (Coord). Entre a Solidariedade e o Risco: História do Seguro Privado no Brasil. 2. ed. Rio de Janeiro: Editora FGV, 2001.

ALEU, Amadeo Soler. Seguro de Incendio. Buenos Aires: Editorial Universidad, 1980.

ANDRADE, José Maria Arruda de. Hermenêutica da ordem econômica constitucional e o aspecto constitutivo da concretização constitucional. Revista Fórum de Direito Financeiro $e$ Econômico, coord. Regis Fernandes de Oliveira e Fernando Facury Scaff, Belo Horizonte, ano 1, n. 1, , p. 265, mar./ago. 2012.

AVELÃS NUNES, António José. A crise atual do Capitalismo. São Paulo: RT, 2012. BAKER, Tom e SIMON, Jonathan. Embracing Risk: , 2002.

BAKER, Tom. "Risk, Insurance, and the Social Construction of Responsibility". In: BAKER, Tom e SIMON, Jonathan. Embracing Risk: The Changing Culture of Insurance and Responsibility, p. 33-48.

BARBER, Benjamin R. Consumidor: como o mercado corrompe crianças, infantiliza adultos e engole cidadãos. Rio de Janeiro: Record, 2009.

BARCELlONA, Pietro. Postmodernidad y Comunidad: el regreso de la vinculación social, 3. ed. Madrid: editorial Trotta, 1999.

BARROSO, Luís Roberto. Natureza jurídica dos recursos que o custeiam. In: DPVAT Um seguro em evolução. O Seguro DPVAT visto por seus administradores e pelos juristas. Rio de Janeiro: Renovar, 2013. p. 120.

BARTHES, Roland. Elementos de semiologia. São Paulo: Cultrix, 2012.

BAVETTA, Giuseppe. L’impreza di assicurazione. Milão: Giuffrè, 1972.

BECK, Ulrich. Risk society revisited. In: ADAM, Barbara, BECK, Ulrich e VAN LOON, Joost (Org.) The risk society and beyond: critical issues for social theory. Londres: Sage Publications, 2007. p. 225-226.

BECK, Ulrich. Risk society: towards a new modernity. Londres: Sage Publications, 1992, p. 9.

BECK, Ulrich. World at risk. Cambridge: Polity, 2009.

BELLUZZO, Luiz Gonzaga. 1929 e 2008: Reações à crise. Carta Capital, São Paulo, ano XIX, n. 767, p. 47, 25 set. 2013,

BELLUZZO, Luiz Gonzaga. Além da conjuntura. Carta Capital. São Paulo, ano XVIII, n. 761, p. 38, 14 ago. 2013. 
BERCOVICI, Gilberto. Constituição econômica e desenvolvimento: uma leitura a partir da Constituição de 1988. São Paulo: Malheiros, 2005.

BERCOVICI, Gilberto. Desigualdades Regionais, Estado e Constituição. São Paulo: Max Limonad, 2003, p. 35-44, 54-67, 291-302 e 312-315.

BERCOVICI, Gilberto. Direito Econômico do Petróleo e dos Recursos Minerais. São Paulo: Quartier Latin, 2011. p. 1970.

BERCOVICI, Gilberto. Estado, Soberania e Projeto Nacional de Desenvolvimento: Breves Indagações sobre a Constituição de 1988. Revista Latino-Americana de Estudos Constitucionais, Belo Horizonte, Del Rey, n. 1, jan./jun. 2003.

BERCOVICI, Gilberto. IRB - Brasil Resseguros S.A. Sociedade de Economia Mista. Monopólio de Fato, Dever de Contratar e Proteção à Ordem Pública Econômica. RDE. Revista de Direito do Estado, São Paulo, v. 12, p. 335-376, 2008.

BERCOVICI, Gilberto. O Estado de exceção econômico e a periferia do capitalismo. Campinas. Disponível em: 〈http://www.unicamp.br/nee/epremissas/pdfs/2/03.02.pdf.> Acesso em: 1 jul.2011.

BERCOVICI, Gilberto: Estado, resseguro e a industrialização brasileira. Separata de Liber Amicorum - Homenagem ao Prof. Doutor António José Avelãs Nunes. Coimbra: Coimbra Editora, 2009.

BERNSTEIN, Peter L. Desafio aos Deuses. 23. ed. Rio de Janeiro: Elsevier, 1997.

BEVILAQUA, Clóvis. Direito das Obrigações. Campinas: Red Livros, 2000.

BONAVIDES, Paulo. Reflexões - Política e Direito. 3. ed. rev. e ampl. São Paulo: Malheiros, 1998.

BORDIEU, P. Meditações pascalianas, apud Z. BAUMAN, Vida para consumo - a transformação das pessoas em mercadoria, Rio de Janeiro: Zahar, 2008.

BORGES, Nelson. A teoria da imprevisão no direito civil e no processo civil, São Paulo: Malheiros, 2002.

BRANCO, Gerson Luiz Carlos. Função Social dos Contratos: interpretação à luz do Código Civil. São Paulo: Saraiva, 2009.

BRASIL. Constituição (1988). Constituição da República Federativa do Brasil, DF: Senado, 1988.

BRASIL. Decreto-Lei n. 73, de 21 de nov. de 1966. Dispõe sobre o Sistema Nacional de Seguros Privados, regula as operações de seguros e resseguros e dá outras providências. Diário Oficial da União. Seção 1, 22 nov. 1966. 
BRASIL. Lei n. 10.406 de 10 de jan. de 2002. Institui o Código Civil. Disponível em: <http://www2.senado.leg.br/bdsf/item/id/185413 $>$.

BRASIL. Lei n. 12.529 de 30 de nov. de 2011. Estrutura o Sistema Brasileiro de Defesa da Concorrência; dispõe sobre a prevenção e repressão às infrações contra a ordem econômica; altera a Lei n. 8.137 de 27 de dez. de 1990, o Decreto-Lei n. 3.689 de 3 de out. de 1941 - Código de Processo Penal, e a Lei n. 7.347 de 24 de jul. de 1985; revoga dispositivos da Lei n. 8.884 de 11 de jun. de 1994, e a Lei n. 9.781 de 19 de jan. de 1999; e dá outras providências. Diário Oficial da União. Seção 1, 2 dez. 2011.

BRASIL. Lei n. 3.071 de 1 de jan. de 1916. Código Civil dos Estados Unidos do Brasil. Diário Oficial da União. Seção 1, 5 jan. 1916.

BRASIL. Lei n. 8.884 de 11 de jun. de 1994. Transforma o Conselho Administrativo de Defesa Econômica (CADE) em Autarquia, dispõe sobre a prevenção e a repressão às infrações contra a ordem econômica e dá outras providências. Diário Oficial da União. Seção 1, 13 jun. 1994, p. 8437 (Publicação original)

BRASIL. Projeto de Lei n. 477/2013. Estabelece normas gerais em contratos de seguro privado. Disponível em:

<http://www.senado.gov.br/atividade/materia/detalhes.asp?p_cod_mate=115225 >

BUARQUE DE HOLANDA, Sérgio. Poesia e crítica in O homem cordial. São Paulo: Penguin Classics Companhia das Letras, 2012.

BUNNI, Nael G. Risk and Insurance in Construction, 2 ed. Oxon: Spon Press, 2003.

BUSQUETS ROCA, Francisco, Teoría general del seguro, Barcelona: Vicens-Vives, 1988.

BUSTAMANTE, Jaime Ferrer e URIBE OSORIO, Ana Inés. Principios jurídicos del seguro, Bogotá: Temis, 1996.

CALMON DE PASSOS, J.J., O risco na sociedade moderna e seus reflexos na teoria da responsabilidade civil e na natureza jurídica do contrato de seguro. In: Anais do I Fórum de Direito do Seguro "José Sollero Filho" (2000). São Paulo: EMTS e IBDS, 2001.

CALMON DE PASSOS, José Joaquim. O Risco na sociedade moderna e seus reflexos na teoria da responsabilidade civil e na natureza jurídica do contrato de seguro. In: I Fórum de Direito do Seguro "Jose Sollero Filho" - Anais, São Paulo: Max Limonad, 2001.

CARTA, Mino. Falta quem pense: porque as lições de Hannah Arendt também valem para o Brasil. Carta Capital, São Paulo, ano XVIII, n. 761, 14 de agosto de 2013.

CASANOVA, Pablo González. O colonialismo global e a democracia. Rio de Janeiro: Civilização Brasileira, 1995.

CHARTERED INSURANCE INSTITUTE. Seguro de ingeniaría. 2. ed. Tradução espanhola de Manuel Vivas Díaz-Berrio, Madri: Ed. Mapfre. 
CÓDIGO DE HAMMURABI. Tradução espanhola de Federico Lara Peinado, 4. ed. Madri: Tecnos, 2008.

COELHO, Fabio Ulhoa. Curso de Direito Comercial. 3. ed. São Paulo: Saraiva, 2002. v. III.

COLLINI, Stephan. Introdução: interpretação terminável e interminável in ECO, Umberto. Interpretação e superinterpretação, 3. ed. São Paulo: Editora WMF Martins-Fontes, 2012. p. 8

COMPARATO, Fabio Konder, Seguro - Cláusula de rateio proporcional - Juridicidade, Revista de Direito Mercantil, n. 7, São Paulo: RT, 1972.

COMPARATO, Fabio Konder. O Indispensável Direito Econômico. In: Ensaios e Pareceres de Direito Empresarial. Rio de Janeiro: Forense, 1978.

COMPARATO, Fábio Konder. O Seguro de Crédito, São Paulo: RT, 1968.

COMPARATO, Fábio Konder. Obrigações de meio, de resultado e de garantia, In: Ensaios e Pareceres de Direito Empresarial, Rio de Janeiro: Forense, 1978.

COMTE-SPONVILLE, André. O capitalismo é moral? São Paulo: Martins Fontes, 2005. CONSELHO ADMINISTRATIVO DE DEFESA ECONÔMICA. Ato de Concentração ${ }^{\circ}$ 08012.005526/2010-39. Requerentes: Banco do Brasil S.A., BB Seguros Participações S.A. e Mapfre Vera Cruz. Relator Alessandro Luis S. Octavini. Voto publicado no Diário Oficial da União de 10.02.2012 n. ${ }^{\circ}$ 30, Seção 1, páginas 44, 45 e 46.

CORDEIRO, António Menezes. Direito dos Seguros. Coimbra: Almedina, 2013. p. 345. COSTA, Edmilson. A globalização e o capitalismo contemporâneo. São Paulo: Editora Expressão Popular, 2008.

CUEVA, Ricardo Villas Boas. IV CONGRESSO INTERNACIONAL DE DIREITO SECURITÁRIO (CIDISE 2013). Palestra: A visão do contrato de seguro na análise da jurisprudência do STJ. São Paulo: 10 jun. 2013.

CUNHA, Sérgio Sérvulo da. Uma deusa chamada Justiça. São Paulo: Martins Fontes, 2009.

DICKSON G. C. A e STEELE, J. T. Introduction to insurance, 2. ed. Londres: Financial Times, 1984.

Díez-Picazo, Luis. Fundamentos del derecho patrimonial. 6. ed. Pamplona: (Esp.), Civitas, 2007. v. I

DOBBYN, John F. Insurance law in a nutshell. 2. ed. St. Paul: West, 1999.

DOUGLAS, Mary e WILDAVSKY, Aaron. Risk and Culture: An essay on the selections of technological and environmental dangers. Berkeley: University of California Press, 1983. 
DUSSEL, Enrique, Vivemos uma primavera política In: Jornadas Bolivarianas. Disponível em: 〈http://www.iela.ufsc.br/?page=noticias_visualizacao\&id=785>. Acesso em: 9 nov. 2009.

EJZENBERG, Wolf. Fiscalização da atividade seguradora - Limites do controle estatal. Revista brasileira de Direito do Seguro e da Responsabilidade Civil, São Paulo, ano I, 1. ed. p. 311-343, 2008.

ELIASHBERG COUILBAULT, Constant e LATRASSE, Michel. Les grands principes de l'assurance, 5. ed. Paris: L’Argus, 2002.

ERICSON, Richard Victor, DOYLE, Aaron e BARRY, Dean. Insurance as governance. Toronto: University of Toronto Press Incorporated, 2003..

ETCHEBARNE, Conrado. El Control por el Estado de las Empresas de Seguro. Revista del Derecho Comercial y de las Obligaciones. ano 3, 1970.

EWALD, François. Governmentality. In: BURCHELL, Graham, GORDON, Colin e MILLER, Peter (Org.) The Foucault Effect: Studies in Governmentality. Chicago: University of Chicago Press, 1991. p. 87-104.

EWALD, François. Insurance and Risk. In: BURCHELL, Graham, GORDON, Colin e MILLER, Peter (Org.) The Foucault Effect: Studies in Governmentality. Chicago: University of Chigado Press, 1991. p. 197-210.

EWALD, François. L'Etát Providence. Introdução - final. Paris: Grasset, 1986.

EWALD, François. The return of Descartes's malicious demon: An outline of a Philosofy of Precaution. In: BAKER, Tom e SIMON, Jonathan. Embracing Risk: The Changing Culture of Insurance and Responsibility. Chicago: University of Chiacgo Press, 2002. p. 273-299.

FACHIN, Luiz Edson e PIANOVSKY RUZYK, Carlos Eduardo. Um Projeto de Código Civil na Contramão da Constituição. In: Revista Trimestral de Direito Civil, 2000. Rio de Janeiro: Ed. Padma, 2000. v. 4.

FARIA, José Eduardo. O Direito na economia globalizada. São Paulo: Malheiros, 2000.

FARIA, Juliana Cordeiro de. Seguro facultativo de responsabilidade civil: a problemática do direito de ação da vítima contra a seguradora na perspectiva do Código Civil de 2002. Tese (Doutoramento em Direito) - Faculdade de Direito da Universidade Federal de Minas Gerais, Belo Horizonte, 2004, (Orientação do Professor Doutor Humberto Theodoro Júnior).

FINANCIAL Management of Large-Scale Catastrophes. Paris: OECD Publications, 2008.

FISCHHOFF, Baruch e KADVANY, John. Risk: A very short introduction. Oxford: Oxford University Press, 2011. 
FMI quer apressar abertura. Revista Cobertura, Rio de Janeiro, 29 mar. 2002. Disponível em: <http://www.revistacobertura.com.br/lermais materias.php?cd materias=51\&friurl=:FMI-quer-apressar-abertura->. Acesso em: 23 nov. 2013.

FURTADO, Celso. Em busca de novo modelo: reflexões sobre a crise contemporânea. São Paulo: Paz e Terra, 2002.

GARCIA, Marco Aurélio. Uma história sem fim. In: Tempo e História. NOVAES, Adauto (Org.). São Paulo: Companhia das Letras, 1992.

GARRIDO Y COMAS, J. J. Teoría general y derecho español de los seguros privados: teoría y práctica de los seguros privados. Barcelona: Consejo General de Agentes y Corredores de Seguros de España, 1986.

GERATHEWOHL, Klaus et. alli. Reinsurance Principles and Practice. Tradução inglesa. Verlag Versicherungswirtschaft e V., 1980. v. II.

GIDDENS, Anthony. The Consequences of Modernity. Stanford: Stanford University Press, 1990.

GLOBALIZAÇÃO e direito da banca, da bolsa e dos seguros: uma resposta européia In: Boletim STVDIA IURIDICA n. 73 - Faculdade de Direito de Coimbra. Coimbra: 2003.

GODOY, Claudio Luiz Bueno de. Função social do contrato, 3. ed. São Paulo: Saraiva, 2009.

GOMES, Orlando. Contratos, 26. ed. Rio de Janeiro: Forense, 2009.

GONDIM, Gonçalves, KENICKE, Pendro Henrique Gallitti e BERTASSONI, Thais Braga TEPEDINO. A causa, os planos do negócio jurídico e a função social: análise a partir da teoria do terceiro cúmplice. In: TEPEDINO, Gustavo e FACHIN, Luiz Edson (org). Pensamento crítico do direito civil brasileiro. Curitiba: Juruá, 2011,Gustavo e FACHIN, Luiz Edson (org). Curitiba: Juruá, 2011.

GRAU, Eros Roberto. A ordem econômica na constituição de 1988 (interpretação e crítica). São Paulo: Editora Revista dos Tribunais, 1990.

GRAU, Eros Roberto. A Ordem Econômica na Constituição de 1988. 9. ed. São Paulo: Malheiros, 2004.

GRAU, Eros Roberto. Elementos de Direito Econômico, São Paulo, Revista dos Tribunais, 1981.

GÜRSES, Özlem. Reinsuring Clauses. Londres: Lloyd's List, 2010.

HADDAD, Luis Gustavo. Função social do contrato - um ensaio sobre seus usos e sentidos. São Paulo: Saraiva, 2013.

HAICAL, Gustavo. Cessão de Crédito - Existência, Validade e Eficácia. São Paulo: Saraiva, 2013. 
HALPERIN Isaac e BARBATO, Nicolas Hector. Seguros: exposición crítica de las leyes 17.418, 20.091 y 22.400. Buenos Aires: Lexis Nexis, 2003.

HANSEL, D. S. Introduction to insurance. Londres: LLP, 1996.

HOBSBAWN, Eric. Era dos extremos: o breve século XX - 1914-1991. 2. ed. São Paulo: Companhia das Letras, 1995.

INSTITUTO BRASILEIRO DE DIREITO DO SEGURO. Contrato de seguro: uma Lei para todos. São Paulo: Quartier Latin, 2013.

INTERNATIONAL TRADE CENTRE UNCTAD/WTO. Export credit insurance and guarante schemes - A practical guide for developing and transition economies. Genebra: ITC, 1998.

IRB BRASIL RESSEGUROS S.A. Seguro D\&O Condições Gerais - AIU D\&O - IRB Brasil RE/Review 01/04. Disponível em: <www2.irb-brasilre.com.br/site/>.

IRIKWU, J. O. Reinsurance in the Third World. Londres: Witherby \& Co. Ltd., 1982. JELLINEK, Georg. L'Etát moderne et son droit - Premiére partie - Théorie générale de l'État. Paris: L.G.D.J., 2005.

JOHNSON, Omotunde E. G. (Org.) Financial Riscks, Stability and Globalization. Washington: International Monetary Fund Publications Services, 2002.

JONAS, Hans. The Imperative of Resonponsibility. Chicago: University of Chicago Press, 1984. p. 5.

JUNQUEIRA DE AZEVEDO, Antonio. Princípios do novo direito contratual e desregulamentação do mercado. Direito de exclusividade nas relações contratuais de fornecimento. Função social do contrato e responsabilidade aquiliana de terceiro que contribuiu para o inadimplemento contratual. Revista dos Tribunais. São Paulo, v.750.

KILBORN, Jason J. Comportamentos econômicos, superendividamento; estudo comparado da insolvência do consumidor: buscando as causas e avaliando as soluções?. In: Estudos de Direito Comparado sobre o superendividamento in Direitos do Consumidor Endividado. (Coord.) Cláudia Lima Marques e Rosângela Lunardelli Cavallazzi. São Paulo: RT, 2006.

LACAN, J. Televisão. Rio de Janeiro: Jorge Zahar, 2003.

LAMBERT-FAIVRE, Yvonne. Droit des Assurances. 11. ed. Paris: Dalloz, 2001.

LAMBERT-FAIVRE, YVONNE. L'evolution de la responsabilité civile d'une dette de responsabilité a une créance d'indemnization, Revue Trimestrielle de Droit Civil. Paris: 1987.

LARRAMENDI, I.H. PARDO, J.A. e CASTELO, J. Manual básico de seguros. Tradução de Maria Armênia de Sousa Vieira, Rio de Janeiro: Edições técnicas. 
LOPES NETO, Silvino. Perspectivas do Direito e Seus Valores no $3^{\circ}$ Milênio in Perspectivas do Direito no Início do Século XXI. Boletim da Faculdade de Direito, Stvdia ivridica, Coimbra, n. 42, colloquia 3, 1999.

LOPEZ, Teresa Ancona. Livre-Arbitrio, Responsabilidade e Produto de Risco Inerente - O paradigma do Tabaco. São Paulo: Renovar, 2009.

LOPEZ, Teresa Ancona. O princípio da precaução e a evolução da responsabilidade civil (Tese apresentada para Professor Titular no Departamento de Direito Civil da Faculdade de Direito da USP), São Paulo, 2008.

LORENZI, Valeria De. Contratto di assicurazione - Disciplina giuridica e analisi economica. Padova: CEDAM, 2008.

LUCARELLI, Francesco, CIOCIA, Maria Antonia. Interessi privati e diritti soggettivi pubblici. Padova: CEDAM, 1997.

LUHMANN, Niklas. Soziologie des Risikos. Berlin/New York: de Gruyter, 1991.

MAGALHÃES, Agamenon. Respostas às críticas feitas em um memorial anonymo, distribuído pelos interessados contra a nacionalização. In: $O$ Anteprojeto de nacionalização das sociedades de seguros e o Instituto de Seguros. 1936.

MAIA DA CUNHA, Fernando Antonio e WARDE JR., Walfrido Jorge. A arbitragem e os limites à atuação do judiciário nos litígios societários. In: YARSHELL, Flávio Luiz; PEREIRA, Guilherme Setoguti J. Processo Societário. São Paulo: Quartier Latin, 2012. p. 725-758.

MARQUES, Cláudia Lima. Contratos no Código de Defesa do Consumidor: o novo regime das relações contratuais, Revista dos Tribunais, São Paulo, 6. ed. 2011.

MARTINS CARDOZO, José Eduardo. Disposições transitórias: Projeto de Lei $\mathrm{n}^{\circ}$ 3.555/2004. IV Fórum de Direito do Seguro José Sollero Filho. 2006, p.597-605.

MARTINS CARDOZO, José Eduardo. O Resseguro na Lei do Contrato de Seguro Constitucionalidade. Revista Brasileira de Direito do Seguro e da Responsabilidade Civil, São Paulo, v. 1, n. 2, MP, dez. 2009.

MARTINS-COSTA, Judith, Parecer inédito intitulado Contrato de resseguro. IRB - Brasil Resseguros S.A.. Contratos necessários. Conexidade contratual. Função social do contrato e exercício jurídico disfuncional. Deveres de proteção. Ilicitude. Sociedade de economia mista. Princípio da impessoalidade e prática discriminatória, emitido em 15 de agosto de 2008.

MARTINS-COSTA, Judith. Parecer inédito mimeo intitulado: Sinistro complexo Extensão do seguro à Namisa - inocorrência de prescrição. Porto Alegre:, 12 fev. 2013.

MARTINS-COSTA, Judith. Prefácio da obra Cessão de Crédito - Existência, Validade e Eficácia, de Gustavo Haical, São Paulo: Saraiva, 2013. 
MARTINS-COSTA, Judith. Reflexões sobre o princípio da função social dos contratos. Revista Direito GV, São Paulo, v. 1, n. 1, 2005.

MARX, Karl e ENGELS, Friedrich. A ideologia Alemã. (Org) Tradução de Marcelo Backes. Rio de Janeiro: Civilização Brasileira, 2007.

MATTEI, Lauro. Teoria do valor-trabalho: do ideário clássico aos postulados marxistas. Ensaios FEE, Porto Alegre, v. 24, n. 1, 2003.

MAYAUX, LUC M. Réflexions sur le principe de précaution et le droit des assurances. In: Revue genérale du droit des assurances, Paris, n. 2. L.G.D.J., 2003.

McCLUSKEY, Martha. Rhetoric of Risk and the Redistribution of Social Insurance. In: BAKER, Tom e SIMON, Jonathan. Embracing Risk: The Changing Culture of Insurance and Responsibility. Chicago: The University of Chicago Press, 2002. p. 146-166.

MELLO FRANCO, Vera Helena de. O contrato de seguro. In: Carlos Alberto Bittar (Org.). Novos Contratos Empresariais. São Paulo: RT, 1990.

MELLO FRANCO, Vera Helena de. Teoria Geral do Contrato: confronto com o direito europeu futuro. São Paulo: RT, 2011.

MELlO FRANCO, Vera Helena. Contratos: Direito Civil e Empresarial. 2. ed. São Paulo: Editora dos Tribunais, 2011.

MELO, Gustavo de Medeiros. Ação direta do terceiro prejudicado no seguro de responsabilidade civil: uma técnica processual a serviço do direito material. Tese (Doutoramento em Direito) - Faculdade de Direito, Pontifícia Universidade Católica de São Paulo, São Paulo, 2013. (Orientação do Professor Doutor Nelson Nery Jr.).

MESSINA DE ESTRELLA GUTIERREZ, Graciela Nora. La responsabilidad civil en la era tecnológica. Buenos Aires: Abeledo-Perrot, 1989.

MONTI, Alberto. Buona Fede e Assicurazione. Milão: Giuffrè Editore, 2002.

MONTIEL AlVAREZ, Ana Maria Blanco. Partilha da Álea no Contrato de Resseguro. Dissetação (Mestrado em Direito) - Faculdade de Direito da Universidade Federal do Rio Grande do Sul, Porto Alegre, 2012.

MORANDI, Juan Carlos F. El riesgo en el contrato de seguro: régimen de las modificaciones que lo agravan. Buenos Aires: Astrea, 1974.

NUNES, António José Avelãs. A crise atual do Capitalismo. São Paulo: RT, 2012.

OCTAVIANI, Alessandro S. Luis. Recursos genéticos e desenvolvimento - Os desafios furtadiano e gramsciano. São Paulo: Saraiva, 2013.

OECD Proceedings: Insurance regulation and supervision in economies in transiction: second east-west conference on insurance systems in economies in transiction. Paris: 1997. 
OPPENHEIM, L. A. The Seafaring Merchants of Ur. Journal of the American Oriental Society, v. 74, n. 1, jan/mar, 1954.

PASSOS, José Joaquim Calmon de. O Risco na sociedade moderna e seus reflexos na teoria da responsabilidade civil e na natureza jurídica do contrato de seguro. In: I Fórum de Direito do Seguro “Jose Sollero Filho” - Anais. São Paulo: Max Limonad, 2001.

PEREIRA FILHO, Luiz Tavares. DPVAT - Um seguro em evolução. O Seguro DPVAT visto por seus administradores e pelos juristas. Rio de Janeiro: Renovar, 2013.

PERLINGIERI, Pietro. O direito civil na legalidade constitucional. Tradução de Maria Cristina De Cicco. Rio de Jnaeiro: Renovar, 2008.

PIMENTEL, José Menéres. Perspectivas para o século XXI. In: Perspectivas do Direito no início do século XXI. Boletim da Faculdade de Direito, Stvdia Ivridica. Coimbra, n. 42, colloquia 3, 1999.

PIZA, Paulo Luiz de Toledo. Contrato de Resseguro, São Paulo: IBDS e EMTS, 2002.

PIZA, Paulo Luiz de Toledo. Contrato de Resseguro: Tipologia, Formação e Direito Internacional. São Paulo: EMTS, 2002.

POLIDO, Walter Antonio. Contrato de Seguro: novos paradigmas. São Paulo: Roncarati, 2010.

PONTES DE MIRANDA, Francisco Cavalcanti. Tratado de Direito Privado. Rio de Janeiro: Borsói, 1958, v. 45.

POPP, Carlyle. A eficácia externa dos negócios jurídicos. In: Teoria Geral dos Contratos. Rena Lotufo, Giovanni Ettore Nanni (Coord.). São Paulo: Atlas, 2011.

PRÖLS, Jürgen, MARTIN, Anton (eds.). Versicherungsvertragsgesetz. 27. ed. Munique: C. H. Beck, 2004.

QUEIROZ, José Luiz de. Comutatividade no contrato de seguro. Dissetação (Mestrado em Direito) - Faculdade Paulista de Direito - Pontifícia Universidade Católica de Sâo Paulo, São Paulo, 2007.

RABEL, Ernest apud Tilmann J. Roder, From industrial to legal standardization, 18711914 - Transnational Insurance Law and The Great San Francisco Earthquake, Boston: 2012.

REALE, Miguel. Função social do Contrato. In: REALE, Miguel. História do Novo Código Civil, Revista dos Tribunais, São Paulo, 2005.

ROCHA, Janes. Repaginado, IRB quer risco rentável. Jornal Valor Econômico, São Paulo, 8 dez. 2009. Jornal Valor Econômico. Disponível em: <http://www.valor.com.br/arquivo/797995/repaginado-irb-quer-risco-rentavel>

ROPPO, Vincenzo. Il contratto, In: Trattato di Diritto Privato a cura di Giovanni Iudica e Paolo Zatti, 2. ed., Milão, Giuffré, 2011. 
ROSARIO, Abelardo Barreto do. Ação Direta da Vítima Contra o Segurador. Rede Ferroviária Federal S.A. Estrada de Ferro Central do Brasil. Departamento Jurídico, Rio de Janeiro: 1967.

ROSS, H. Laurence. Settled out of Court - The social process of Insurance Claims Adnustments. 1. ed. Chicago: Aldine Publishing Company, 1970.

ROUX AZEVEDO, Luís Augusto. A comutatividade do contrato de seguro. Dissetação (Mestrado em Direito) - Faculdade de Direito - Universidade de São Paulo, São Paulo, 2010.

RÜHL, Giesela. Conflict of Laws in a Globalized World. Cambridge: 2007.

SCHREIBER, Anderson. Novos paradigmas da responsabilidade civil - Da erosão dos filtros da reparação à diluição dos danos. 2. ed., São Paulo: Atlas, 2009.

SCHREIBER, Anderson. Novos paradigmas da Responsabilidade Civil - Da erosão dos filtros da reparação à diluição dos danos. 2. ed. São Paulo: Atlas, 2009.

SERQUEIRA, Francisco; PAREDES, Jorge; QUIRÓZ Hernan e CANALES, Nicolás. Seguros Obligatórios. In: Anais XII CONGRESSO IBEROAMERICANO DE DERENCHO DE SEGUROS - II CONGRESSO INTERNACIONAL DEL SEGURO Assunción 27-29 abr. 2011. Assunção: Seção Paraguaia da AIDA - Associação Internacional de Direito do Seguro.

SHEARING, Clifford e WOOD, Jennifer. Imagining Security, Cullompton: Willan Publishing, 2007. Tradução espanhola: Pensar La seguridad, Barcelona: Gedisa, 2011.

SILVEIRA, Paulo: Lacan e Marx: a ideologia em pessoa. In: Crítica Marxista, n. 14, São Paulo: Boitempo, 2002.

SLOVIC, Paul. The Feeling of Risk: New Perspectives on Risck Perception. Londres: Earthscan, 2010.

SLOVIC, Paul. The Perception of Risk. Londres: Earthscan, 2000.

SMITH, Adam. A mão invisível. Tradução brasileira de Paulo Geiger, 1. ed. São Paulo: Penguin, 2013.

STIGLITZ, Rubén S. Derecho de seguros. Tomo 1, 4. ed. Buenos Aires: La Ley, 2004. SZTAJN, Raquel. Função social do contrato e direito de empresa. In: RDM n. 139, jul/set. 2005, p. 29-49, São Paulo: Malheiros.

TEPEDINO, Gustavo. Crise das fontes normativas e técnica legislativa na parte geral do Código Civil de 2002. In: TEPEDINO, Gustavo (Coord.). A parte geral do novo Código Civil: Estudos na perspectiva civil-constitucional, 3 ed. Rio de Janeiro: Renovar, 2007.

TEPEDINO, Gustavo. O Novo Código Civil: duro golpe na recente experiência constitucional brasileira, editorial Revista Trimestral de Direito Civil, Rio de Janeiro, v. 7. Ed. Padma, 2001. 
TEPEDINO, Gustavo. O problema da causalidade no seguro obrigatório por danos pessoais causados por veículos automotores de via terrestre (DPVAT). In: DPVAT - Um seguro em evolução. O Seguro DPVAT visto por seus administradores e pelos juristas. Rio de Janeiro: Renovar, 2013.

TEPEDINO, Gustavo. Opinião doutrinária. Inédita mimeo, de 23 nov. 2012, Rio de Janeiro.

TERBILLE, Michael (ed.). Versicherungsrecht: Münchener Anwalts Handbuch. Munique: C. H. Beck, 2004.

THEODORO JR., Humberto. O contrato e sua função social. 3. ed. Rio de Janeiro: Editora Forense, 2008.

THEODORO JÚNIOR, Humberto. A regulação do sinistro no direito atual e no Projeto de Lei ${ }^{\circ} 3.555$, de 2004. In: IV Fórum de Direito do Seguro José Sollero Filho. São Paulo: Instituto Brasileiro de Direito do Seguro, 2006. p. 183-215.

TIMM, Luciano Benetti. O novo direito civil - ensaio sobre o mercado - a reprivatização do Direito Civil e a privatização do Direito Público. Porto Alegre: Livraria do advogado Editora, 2008.

TZIRULNIK, Ernesto e OCTAVIANI, Alessandro S. Luis. Regulação de Sinistro (ensaio jurídico), 3. ed. São Paulo: Max Limonad, 2001.

TZIRULNIK, Ernesto e PIZA, Paulo Luiz de Toledo. Notas sobre a natureza jurídica e efeitos da apólice de seguro no direito brasileiro atual. Disponível em: <http://www.ibds.com.br/artigos/NotasSobreaNaturezaJuridicaeEfeitosdaApolicedeSeguro noDireitoBrasileiroAtual.pdf $>$.

TZIRULNIK, Ernesto, CAVALCANTI, Flavio de Queiroz Bezerra e PIMENTEL, Ayrton. Contrato de Seguro - De acordo com o Novo Código Civil Brasileiro, São Paulo: 2. ed. Revista dos tribunais, 2003.

TZIRULNIK, Ernesto. A constrição judicial de bens garantidores de provisões ou reservas técnicas, opúsculo, São Paulo: ETAD, 1998.

TZIRULNIK, Ernesto. Apontamentos sobre a operação de seguros, Revista Brasileira de Direito de Seguros, Rio de Janeiro, n. 1, 1997.

TZIRULNIK, Ernesto. Contrato de Seguro: Arbitragem é Instrumento e não Função. Disponível em: <http://capitolio.com.br/opinioes/2013/05/09/contrato-de-seguroarbitragem-e-instrumento-e-nao-funcao/>. Acesso em: 16 nov. 2013.

TZIRULNIK, Ernesto. Direito ao seguro privado: discriminação e ação afirmativa. In: Tratado Luso-Brasileiro da Dignidade Humana, MIRANDA, Jorge e SILVA, Marco A. Marques da (Coord.). São Paulo: Quartier Latin, 2008. 
TZIRULNIK, Ernesto. El seguro de responsabilidad civil, su función social y la acción directa en el derecho brasileño contemporáneo. El derecho de contratos en los umbrales del siglo XXI. In: Memorias de las Jornadas Internacionales de Derecho de Contratos Celebradas en la Habana, Cuba, en el período 2001-2007. São Paulo: MP Ed, 2007.

TZIRULNIK, Ernesto. Manifestação Pública do IBDS - Instituto Brasileiro de Direito do Seguro sobre o Projeto de Lei de contrato de seguro. Deputado Armando Vergílio, relator do Projeto na Comissão Especial do PL 3.555/2004 apresenta Substitutivo desastroso para os consumidores, empresários, sociedade civil em geral, seguradoras, resseguradores e corretores: uma lei de seguro atécnica e reacionária. Disponível em: $<$ http://www.ibds.com.br/artigos/ibds-manifestacao-publica-pl3555-substitutivo-deputadoarmando-vergilio.pdf. $>$. Acesso em: 21 dez. 2013.

TZIRULNIK, Ernesto. O Contrato de Seguro - De acordo com o novo Código Civil Brasileiro. 2. ed. atual. e ampl. São Paulo: Revista dos Tribunais, 2003.

TZIRULNIK, Ernesto. O contrato de seguro de acordo com o novo Código Civil. 2. ed. São Paulo: Revista dos Tribunais, 2003.

TZIRULNIK, Ernesto. Direito ao seguro privado: discriminação e ação afirmativa. Tratado Luso-Brasileiro da Dignidade Humana, São Paulo: Quartier Latin, 2008.

TZIRULNIK, Ernesto. Em torno do interesse segurado e da responsabilidade civil. In: Seguros: uma questão atual. Instituto Brasileiro de Direito do Seguro e Escola Paulista da Magistratura (Org.) São Paulo: Max Limonad, 2001.

TZIRULNIK, Ernesto. La póliza D\&O. In: III Jornadas de Reaseguro, 2005. Memorias de las III Jornadas de Reaseguro. México, DF: Swiss Re, 2005.

TZIRULNIK, Ernesto. O futuro do seguro de responsabilidade civil, Revista dos Tribunais, São Paulo, v. 782, 2000.

TZIRULNIK, Ernesto. Parecer sobre seguro de riscos diversos - valores excludentes de infidelidade ato doloso e cumplicidade, Revista dos Tribunais, São Paulo, v. 725, 1996.

TZIRULNIK, Ernesto. Princípio indenitário no contrato de seguro. Revista dos Tribunais, São Paulo, v. 759, 1999.

VAUGHAN, Emmett J. e ELLIOTT, Curtis M. Fundamentals of risk and insurance. 2. ed. Nova Iorque: John Wiley \& Sons, 1978.

VIZENTINI, Paulo G. F. Política externa e desenvolvimento no regime militar. In: Princípios, São Paulo, n. 51, p. 56-65, nov./jan. 1998/1999.

VON BRUCK LACERDA, Maurício A. O Seguro dos Administradores no Brasil - O D\&O Insurance Brasileiro. Curitiba: Juruá, 2013.

WALD, Arnoldo Wald. Obrigações e contratos. São Paulo: RT, 1994. 
WALD, Arnoldo. Caracterização do grupo econômico de fato e suas consequências quanto à remuneração dos dirigentes de suas diversas sociedades componentes. In: Revista de Direito Bancário e do Mercado de Capitais, São Paulo, v. 25, 2004.

ZAPPINO, Jorge S. El Instituto Mixto Argentino de Reaseguros - La formación de un mercado nacional de seguros (1946-1952). 1. ed. Buenos Aires, jun. 2007. 